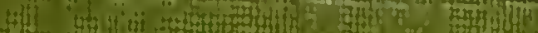



$582.35(410)$ LOW 

THE YOWNG COLLEUTUR

\section{BJPRTSA FERNS}

\section{Br E.d Low E, F R.S.}

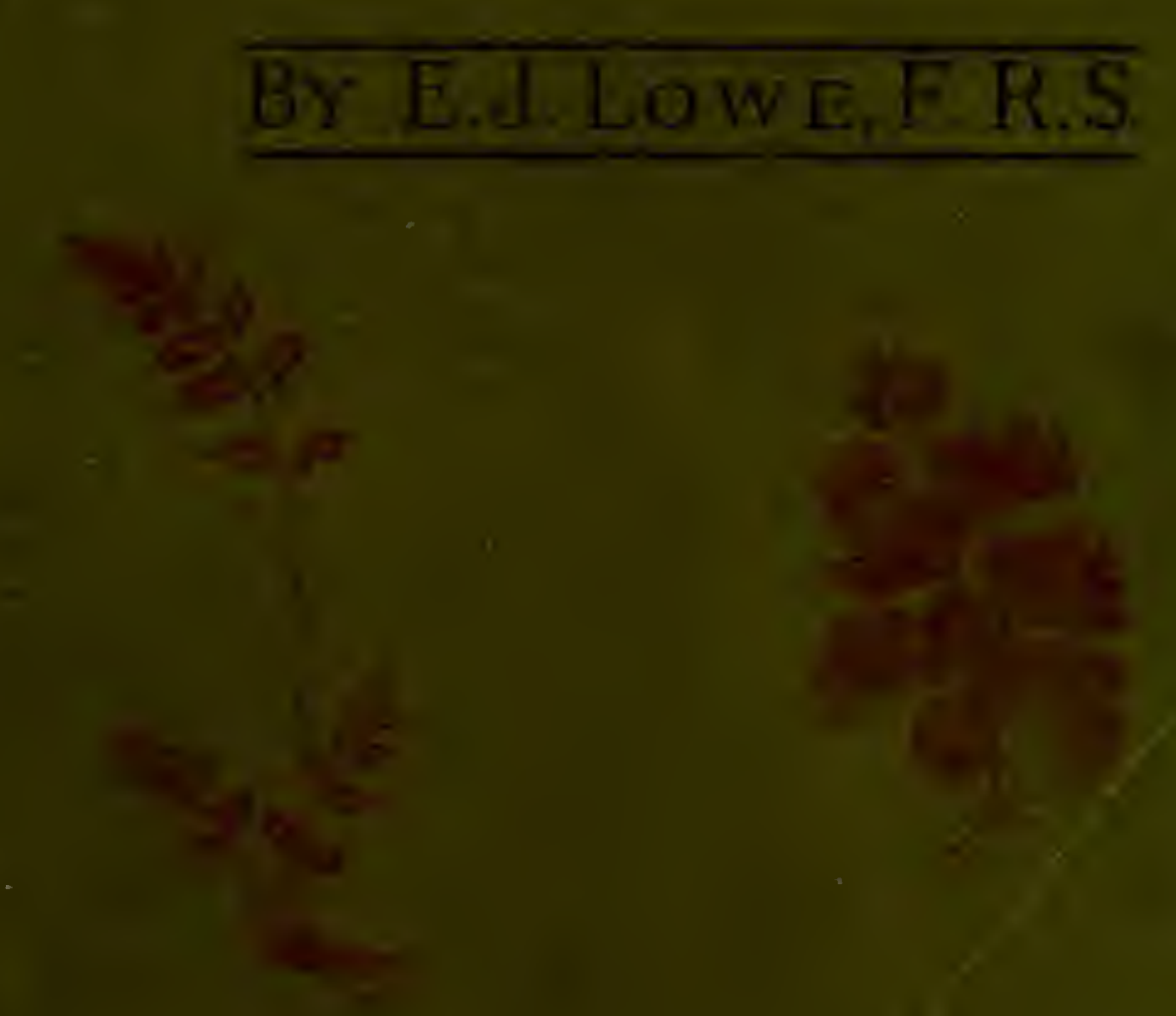

,

ONE SERLWNG 

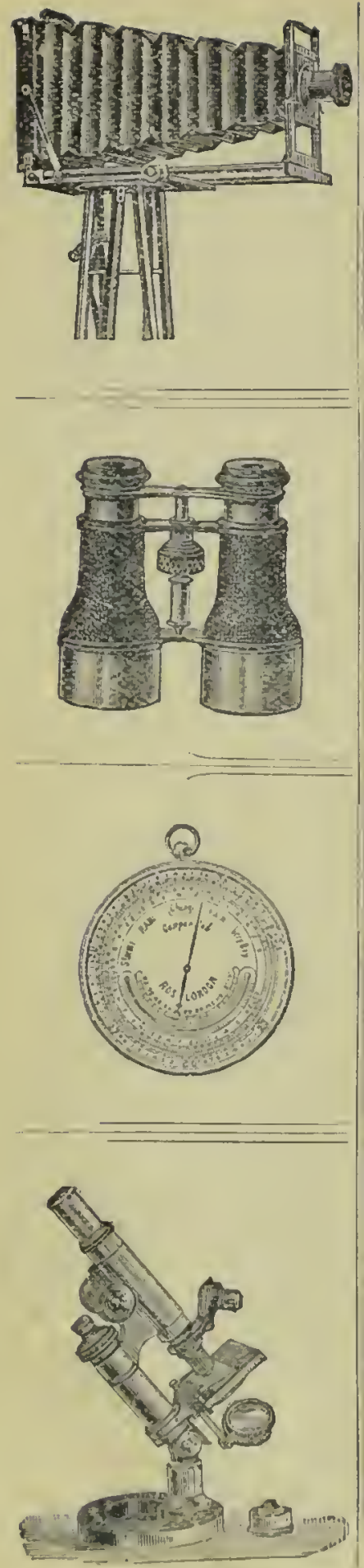

Established 1830.

CATALOGUES FREE.

$$
\text { (0) }
$$$$
\text { ROSS }
$$
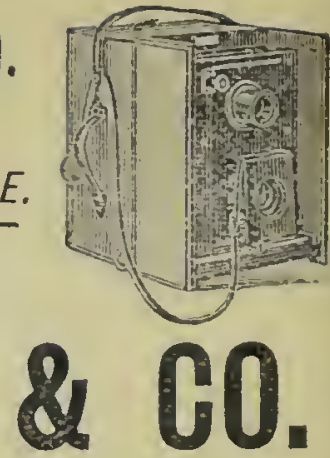

ittaunfuturers of celcbrated PHOTOGRAPHIC LENSES,

With many reeent improvements. Great variety. PHOTOGRAPHIC APPARATUS

of the most reliable linel. Ins]ection inviterl. SPECIAL HAND CAMERAS,

For Travellers in every climate, Have no rivals.

FIELD \& MARINE GLASSES.

Finest quality at Low Priees. Splendid value. SPORTING TELESCOPES.

Used all over the World by Sportsmen and ofticers. ANEROID BAROMETERS.

New form, mounted in Aluminim, higlly" tecommended. COMPASSES \& THERMOMETERS. Special Sets. Mounted in Travelling Cases. SURVEYING INSTRUMENTS

Of every kind, at Mol erate Prices. DRAWING INSTRUMENTS, lor Seliools, Colleges, and every lumplost. MICROSCOPES \& APPARATUS.

special Serres of stands for Studentr. SPECTACLES \& EYE-GLASSES.

lnstructions for self-testing free by jost \&c. \&C.

\section{T月O RO 111, NEW BONDST. $\therefore U 00$ UU. LONDON, W.}

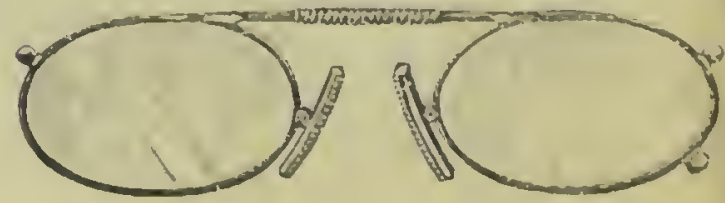

(2) 


\section{$582 \cdot 35(410) \mathrm{LDW}-$}

\section{WATKINS \& DONCASTER, $\rightarrow$ Haturalists, \\ AND}

IManufacturers of Entomological Apparatus and Cabinets.

Plain liing Ncts, wire or cane, including Stick, 1s. 3ı., 2s., 2s. 6d. Folding Nuts, 3s. 64l., 4s. Umbrella Nets (self-acting), 7s. Pocket Boxes, 6d., 9d., 1s., 1s. thl. Zinc Relaxing Boxes, 9d., 1s., 1s. 6d., 2s. Nested Chip Boxes, 8d. per four dozen. Entomological Pins, assorted or mixed, 1s. 6d. per oz. Pocket Lanterns, 2s. 6d. to 10s. 6d. Sugaring Tin, with brush, 1s. 6d., 2s. Sugaring Mixture, ready for use, 1s. 9d. per tin. Store Boxes, with camphor cells, 2s. 6d., 4s., 5s., 6s. Setting Boards, flat or oval, 1 in., 6d.; $1 \frac{1}{2}$ in., sd. ; 2 in., 10d. ; $2 \frac{2}{2}$ in., Is. ; $3 \frac{1}{2}$ in., 1s. 4 d. ; 4 in., 1s. 6 d. ; 5 in., 1s. 10d.; Completc Set of fourteen Boards, 10s. 6d. Setting Houses, 9s. 6d., 11s. 6d.; corker back, 14s. Zinc Larva Boxes, 9d., 1s., 1s. 6d. Breeding Cage, 2s. 6d., 4s., 5s., 7s. 6d. Coleopterist's Collecting Bottle, with tube, Is. 6d., 1s. Sd. Botanical Cases, japanned, double tin, 1s. 6d., 2s. 9d., 3s. 6d., 4s. 6cl. Botanical Paper, 1s. 1d., 1s, 4d., 1s. 9d., 2s. 2d. per quirc. Insect Glazed Cascs, 2s. 6d. to $1 \mathrm{ls}$. Cencnt for replacing Antenne, 4d. per bottle. Stcel Forceps, 1s. 6d., 2s., and 2s. 6d. per pair. Cabinet Cork, 7 by $3 \frac{1}{2}$, best quality, 1s. 4 d. per dozen sheets Brass Chloroform Bottle, 2s, Insect lens, 1s. to $8 \mathrm{~s}$. Glass-top and Glass-bottomed Boxes, from 1s. 4d. per dozen. Zinc Killing Box, 9d, 1s. Pnpa Digger, in leathcr sheath, Is. $9 \mathrm{~d}$. Taxidcrinist's Companion, containing most necessary implements for skinning, 10s. 6d. Scalpels, Is. 3d. Scissors, 2s. per pair. Egg-drills, 2d., 3d., 1s. Blowpipes, 4 4l., 6d. Artificial Ijyes for Birds and Alimals. Label-lists of British Butterflies, 2d. ; .litto of Birds' Eggs, 3d., 4d., 6d. ; ditto of Land and Fresh-water Shclls, 2d. ; Useful Books on Insects, Eggs, \&c.

NOW READY.-TAE EXCHANGE LIST AND LABEL LIST. Compiled by Mr. ED MEYRICK, B.A., F.L.S., F.E.s., accolding to his recent Hanuluole of British Lepidoptera. Exchange List.; 1 dd. each ; Sd. per doz. ; 4s. ner 100. Label Lists, 1s. 6a. eacl.

OUR NEW LABEL LIST of British Macro-Lepidoptera. with Latin and English nanes, 1s. 6d. OUR NEW COMPLETE CATALOGUE of Britisl Lepidoptera (crery species numbered), 1s. ; or on one side for labels, $2 \mathrm{~s}$

"THE "DIXON" LAMP-NET. Inra!usble for taking Moths off street-imms without climbing the lanp-posts), 2s. 6d.

\section{SHOWROOM FOR CABINETS}

Of cvery description, for Insects, Birds' Eggs, Coins, Microscopical Objects, Fossils, \&c. Catalogue (66 Pages) sent on application, Post-free.

\section{A IARGE STOCK OF INSECTS AND BIRDS' EGGS (BRITISF, EUROPEAN, AND EXOTIC).}

Birds, Mammals, \&c., Preserved and Mounted BY FIRST-CLASS WORKMEN. 


\title{
TRoual
}

\section{Prevention of Criblty to Animals, \\ 105, Jermyn Street, St. James's, London.}

\author{
3atrons.
}

HER MOST GRACIOUS MAJESTY THE RUEEN,

THEIR ROYAL HIGHNESSES THE PRINCE AND PRINCESS OF WALES,

\section{EXTRACT FROM A LETTER TO THE SOCIETY FROM THE QUEEN.}

"Amongst other marks of the spread of enlighteument amongst my subjects, L notice, in particular, with real pleasure, the growth of more humane feelings towarls the lower aninals; no civilization is complete which does not include the dumb and defenceless of God's creatures within the sphere of charity and merey."

\section{juresiornt.}

\section{HIS ROYAL HIGHNESS THE DUKE OF YORK.}

UPON this Institution, founded in 1824 (the only one having for its objeet the protection of dumb and defenceless animals), rests a heary responsibility. It is earnestly and respectfully submitted that it has in consequenee a strong elaim upon the benevolence of the humane and charitable.

Trained offieers are despatched to all parts of the kingdom.

7320 convictions during 1896.

The inereased operations of the Soeiety have drawn from the funds an amount vastly exceeding the yearly subseriptions. The Committee neel mueh greater assistanee, and unless such additional support be extended to them, their most righteous eause of humanity inust suffer from insuffieieney of means to earry out those many urgent measures which every well-wisher of the Society has so deeply at heart. Remittances may be forwarded to

JOHN COLAM, Secretary.

\section{SUPPORTED ONLY BY VOLUNTARY CONTRIBUTIONS.}

The objects of other Charitles are divided among many Associations, but this Charity stands alone-the defender of the defenceless - without any assistant.

THE ANIMAL WORLD: A MONTULY ADVOCATE OF HUMANTTY.

Published by the above Society. On thick white paper, priee 2l., sixteen folio pages, with wrapper, aud Illustristel. 'J'he matter consists of Sletehes, stories, Anecolotes,

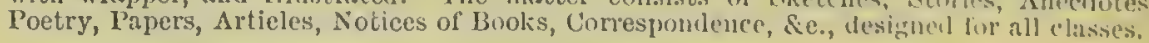

BAND OF MERCY,-Illustratal Jommal of the Banel of Mercy Movement, price ded. inontlily, consisting of ciglit quarto pages. Intended for chiluren.

"I fecl it a duty to entreat public attcntion to a systematic training among all classes,

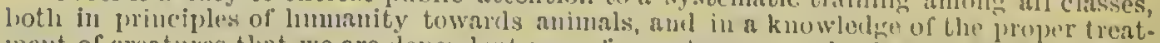
ment of creatures that we are dependent upon for sustenance and of here comforts of life."

The liaroness Buritell-coutts. 


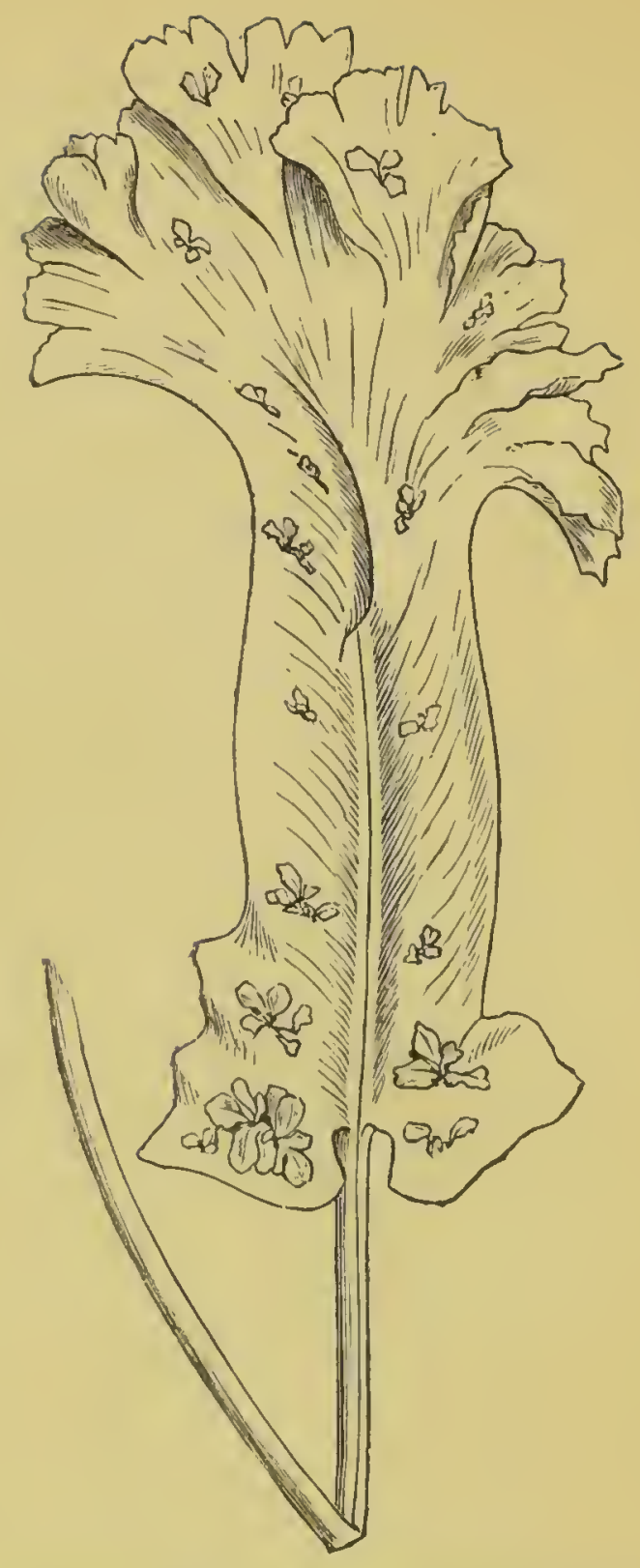

Scolopendrium vulgare, var. Viviparum (showing bulbiferous plants). Sec Fage $8 \mathrm{t}$. (From "The Gardencr's Chronicle.") 


\section{BRITISH FERNS,}

AND

\section{WHERE FOUND.}

E. J. LOWE, Eso., F.R.S., F.L.S., F.G.S., F.Ror.M.S., ETC.

Author of "Oxr Native Ferns." etc.
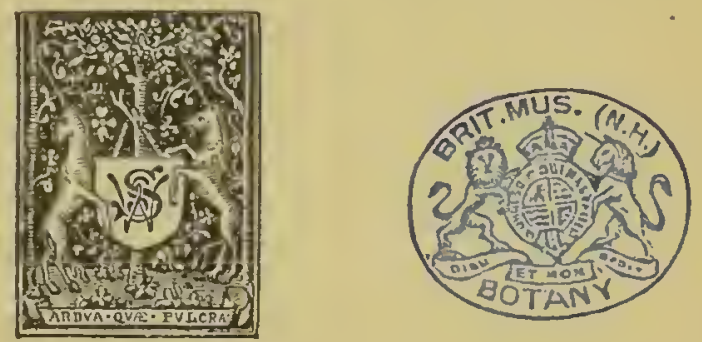

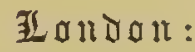

SWAN SONNENSCHEIN \& CO., PATERNOSTER SQUARE.

ISgo. 
Butler \& TANner,

The Selwond Printing Works,

Frome, and London. 
IN

AFFECTIONATE REMEMLRANCE

OF THE

LATE COLONEL A. M. JONES,

WHOSE

LARGENESS OF HEART AND STANCH FRIENDSHIP ARE TRAITS THAT CANNOT BE FORGOTTEN,

AND WHOSE:

ENTHUSIASTIC LABOURS AND KELN PERCEPTION

ENABLED HIA TO DO SO MUCH

FOR THE ADVANCEIIENT OF THIS, HIS FAVOLRITE SUBJECT.

E. J. LOWE. 


\section{P R E F A C E.}

THE Author of this Handbook is anxious to acknowledge the great help that he has reccived from his numcrous fern friends. More especially are these thanks due to Dr. F. IV. Stansficld, of Sale, without whose valuable assistance and suggestions (notably as regards classification) it would have been impossible to have written this work in six wccks. The book was required at a short notice, and therefore it is hoped that any imperfections will be clcalt with mercifully.

To Dr. Maxwell Masters, Mr. E. F. Fox, Mr. WV. H. Phillips, Mr. J. H. litt, Mr. WV. Barnard-Hankey, Mr. R. Thompson, Mr. J. M. Barnes (now deceased), Mrs. Grant, Mrs. Barnes, Colonel Randall, Mrs. Lewis, Mrs. Curre, Mr. Elworthy (son of the late Mr. C. Elworthy), Messrs. Birkenhead, Messrs. Backhouse, Mr. H. S. I'cry; Mrs. J. K. Hodgson, Miss Jones, Mrs. Bagnall Oakele!; Mr. J. Garnett, Mr. R. L. I'racger, Mr. Martin-Atkins, Mr. P. B. ()'Kclly, Mr. C. T. Druery, Major Cowburn, Mr. Stabler, Mr. IV. (i. Baker (Botanic Gardens, Oxford), Mr. J. W. Morris, and others, his thanks are also specially due, for plants, fronds, and various information.

The Author has received great help from the invaluable "Nature Printed Impressions of British Ferns," by the late Colonel A. M. Jones, and from an examination of his clried fronds, and his valuable coliection of historical ferns now growing in the Clifton Zoological Gardens (under the superintendence of the Author), containing divisions of the principal original wild finds of various collectors, as well as those raised by Colonel Jones and others. Further sources of information have becn "Choice liritish lerns," by Mr. C. T. Druery; "Ferns of the English Lake Country" by" Mr. J. M. Larnes; "The Ferns of Ulster," by Mr. WV. H. I'hillips and MI. R. Ll. I'raeger" "Select Lists of IBritish lerns," by Messis. F. IV. and 11. Stansfield ; "European Ferns," by M1r. J. liritten ; "Geographical llandbook of Jerns," by Mrs. Lyell; and "Historical Notes of Fcrus," MSS. by Mr. L. F. Fox.

To these must be added the Author's acquantance with the 
collections of growing plants at Milnthorp (the late Mr. J. M. Barnes), at Scarborough (the late Mr. A. Clapham, dispersed) ; at Bulwell and Exeter (the late Rev. C. Padley, dispersed); at Usk (the late Mr. Carbonell, now at the Royal Gardens, Kew); at Chislehurst (Mr. G. B. Wollaston), Nettlecombe Court (Sir Alfred Trevellyan), Darlaston Hall (the late Mr. Swynfen-Jervis), Rolleston Hall (the late Sir Oswald Mosley), Hawkchurch (the late Mr. J. Wills, dispersed), Chelsea Botanic Gardens (the late Mr. T. Moore), Edinburgh (Mr. P. N. Fraser), Ilfracombe (Mr. J. Dadds), Torbay (Miss Kitson, dispersed), Hartfield, Birmingham (Mr. J. E. Mapplebeck); at Iona House, Clifton (Mr. Martin-Atkins), Hillersdon House, Exeter (Mrs. Grant), Exeter (the late Mr. R. Gray, dispersed), Brislington (Mr. E. F. Fox); at Bowdon (the late Mr. J. Sidebotham), IVindermere (Mr. J. Clowes), Bowness (Mr. Garnett, and Mr. Wilson), Scarborough (the late Mr. C. Glave, dispersed), Whitby (the late Mr. WV. Willison, dispersed), Malton (the late Mr. Monkman, dispersed), Levens (Mr. Stabler), York (Messrs. Backhouse and Mrs. Buckle), Marwood (the late Rev. F. Mules), Papplewick (the late Mr. Riley, dispersed), Foots Cray (the late Mr. R. Sim), Kirkcaldy (Mr. Sang) Tunbridge Wells (The late Mrs. Delves, dispersed), Wentworth (the late Mr. J. Henderson), Vauvert, Guernsey (the late Mr. J. James, dispersed), Glasnevin Gardens (the late Mr. D. Moore), Belfast (Mr. WV. H. Phillips), Edinburgh (the late Mr. Tait, dispersed), Holywood (Mr. R. Ll. Praeger), Ulverston (Mrs. Hodgson), South Kensington Museum (Mrs. Cowper), Ilfracombe (Mr. R. Moule), Charmouth (Mr. J. Moly), etc.

To Mr. John C. Nimmo, Publisher, London, the Author is indebted for the use of the Illustrations, and for which he offers his thanks.*

* The Author is aware that some of the varietics are not sufficiently distinct to be retained; this, however, can be more satisfactorily discussed by the Fern Conference from a careful examination of fronds. A few additional varieties will be found in an Addendum. 


\section{CONTENTS.}

Varieties and Nomenclature

Ferns of Europe proper

Woodsia Ilvensis, $R$. Brozun

hyperboren, $R$. Broziln .

Hymenophyllum unilaterale, Bory

$$
\text { ,' }
$$

Tunbridgense, Smith

Trichomanes radicans, Suartz

Cystopteris fragilis, Bernharti

$$
\text { " alpina, Desvanx }
$$

Adiantum Capillus-Veneris, Limncus

Cryptogramme crispa, $K$. Brown

Pteris aquilina, Lillnces

Iomaria Spicant, Desoanx.

\begin{tabular}{|c|c|c|c|c|}
\hline I & Trichomanes, Linncus & . & - & - \\
\hline " & septcntrionale, Hoffmann & - & - & - \\
\hline ," & marinum, Linncess . & - & - & $\cdot$ \\
\hline " & Germanicunı, Weis . & - & - & $\cdot$ \\
\hline & Ruta-muraria, Linnces & - & • & $\cdot$ \\
\hline & Adiantum-nigrum, Linncus & - & $\cdot$ & • \\
\hline & fontanum, Bernhardi. & - & $\cdot$ & $\cdot$ \\
\hline & $\begin{array}{l}\text { lanceolatum, Hudson • } \\
\text { I"ilix-fœenina, Bcrnhardi (s }\end{array}$ & (sub-sectio & & \\
\hline
\end{tabular}

Asplcnium viricle, Hudsou

VARIETIES.

I'AG $\mathbb{E}$

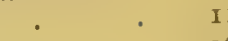

$\cdot 16$

none $\quad 19$

2 . 20

2 I

$\begin{array}{ll}13 & \quad 21 \\ 16 & 23\end{array}$

none $\quad 25$

none 25

$32 \cdot 25$

none $\cdot 28$

$16 \quad 29$

$83 \cdot 3^{\circ}$

$12 \cdot 34$

$27 \cdot 35$

none $\quad 39$

28 .

none $\cdot+3$

$16 .+4$

$15 \cdot+5$

$5 \cdot 47$

I2 . 48

Section ramosum . .

$29 \cdot 5^{x}$

grandiceps . $\quad \cdot \quad \cdot \quad \cdot \quad \cdot \quad \cdot 29$

cristatum . . . . ff

cruciatum . . . . . 59

congestum . $\quad . \quad \cdot \quad \cdot \quad \cdot \quad \cdot 21$

crispatunı . . .

flcxuosum . . . . . . 17

plumosum .

dissectum

laxum .

clepaupcratum

rotundatum

lineare

laciniatum

Cetcrach, Linuexus lunulatum . $\quad . \quad \cdot \quad$. 22

\section{Scction ramosum}

, ramo-inacquale . . . . . 33 
Aspidium Lonchitis, Sivar/z (subsection Polystichum)

VARIETIES.

" aculeatum, Sivartz ".

" angulare, Kitaibel

Section ramosum

$$
\text { . }
$$

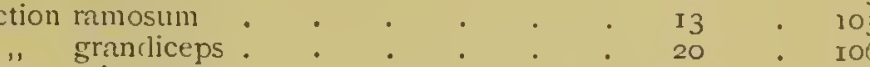

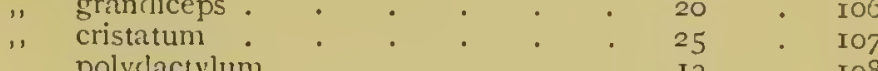

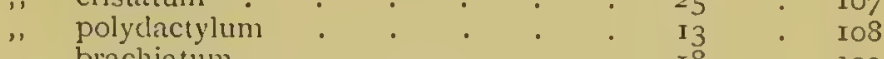

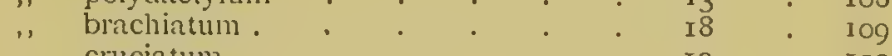

" cruciatum. . . . . . IO

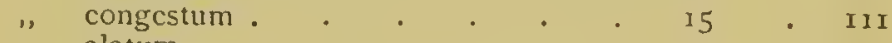

" alatum • . . . . 78 . III

" flexuosum . . . . . . 8 . 8 . 112

") $\quad$ stipatum $\cdot \cdot \cdot \cdot \cdot 77$. $\cdot 113$

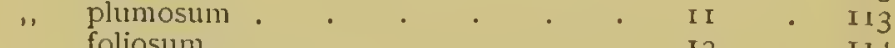

", foliosum • . . . . 13.114

", pulcherrimum • . . . . 3 . 314

". macropinnulum . . . . . 8 . 815

"lecompositum : $: \quad \therefore \quad 55$

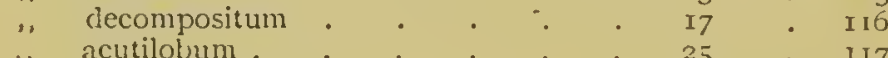

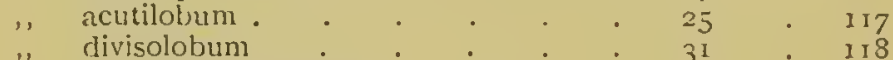

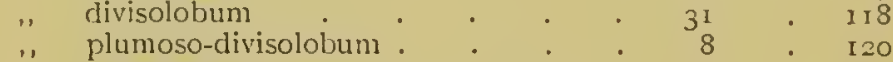

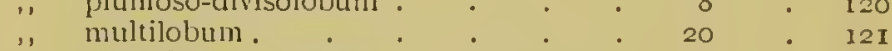

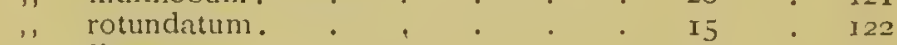

", lineare $.5 . \quad \cdot 17 \div 123$

". laciniatum : : . . $: 25: 124$

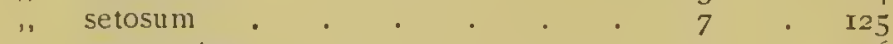

". perserratum : $: 505$

," cleltoideum . . . . . . . 7 . 726

" angustatum $\quad . \quad$. $\quad . \quad$. $\quad 4 \quad$. 127

Nephrodium thelyptcris, Deseaux (subsection Lastrea)

$\begin{array}{cc}9 & 127 \\ \text { none } & 128\end{array}$

montanum, Baker " . . 77 . 128

Filix-mas, Richard

paleaceum, Don

propinquum, Lozve

cristatum, llichaux

rigidum, Desvanx

spinulosum, Desiaux

Scction aenulum

$\begin{array}{rr}52 & \cdot \quad 133 \\ 40 & : \quad 138\end{array}$

$28 \cdot$ IfI

$5 \cdot 1+3$

$6 \cdot 1+4$

$\cdot \cdot 145$

$6 \cdot 1+6$

$23 \cdot 1+7$

$17 \cdot 148$

" dilatatum .

I'olypoclium Plegopteris, Linnceus

$\begin{array}{cc}6 & 1+9 \\ \text { none } & 1 \\ 150\end{array}$

none .150

$+\cdot 15 \mathrm{I}$

alpestre, Hoppe

vulgare, Limnaus

Section plumosum

cristatum.

sentilacerum

i, anomalum

Gynnogramme leptophylla, Disvatux .

Osmunda regalis, Linnaus.

Botrychium Lunaria, Swartz

Ophioglossum vulgatum, Linnerus

Numler of species +5

Concluding Remarks .

varicties, 1794

Aclditional Varieties 


\section{INDEX TO ILLUSTRATIONS.}

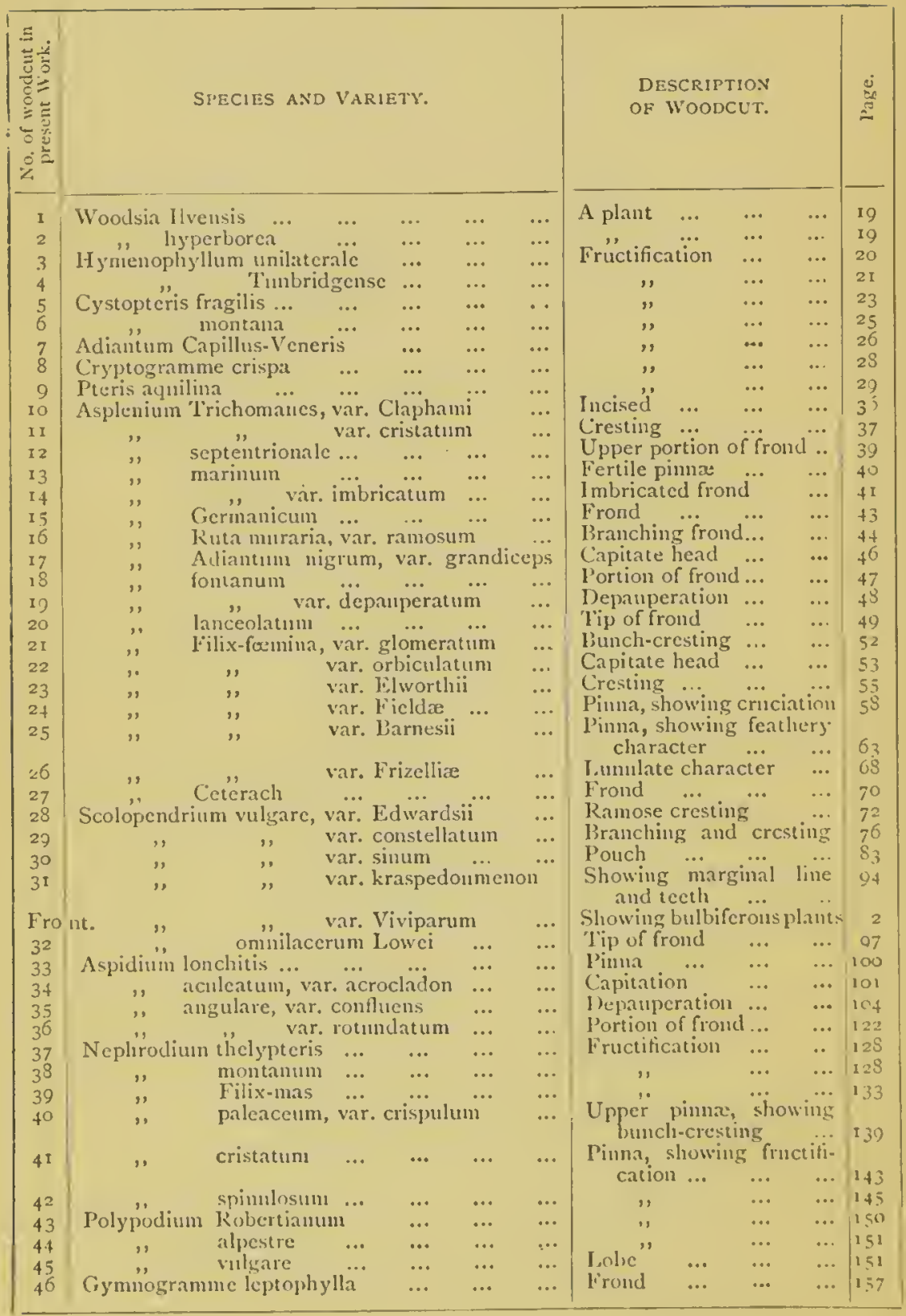




\section{Uarieties of the JBritish jferits.}

THESE have been described in I 859 in "Nature-Printed British Ferns," by Mr. Thomas Moore ; in "Our Native Ferns," in I867, by the Author of this Handbook ; in I 876 to I 880 , prizately (6 parts) in "Varieties of the British Species of Ferns," nature-printed, by" Colonel A. M. Jones; in 1878, in "Ferns of the English Lakes," edited by Mr. J. M. Barnes; and in IS88, in "Choice British Ferns," by Mr. C. T. Druery.

For elaborate descriptions the reader is referred to these works; but the vast increase in our knowledge of this subject, during the last few years, has caused the earlier works to be out of date. Many varieties were unknown when they were written, and a number of unimportant forms have now to be rejected. The English Lakes are, of course, restricted to a prescribed area'; and Mr. Druery's excellent "Choice British Ferns," as the name implies, is limited to the most striking departures from the normal forms; and even in extraordinary varieties there are many beautiful ferns that have been discovered during the past two years, and others that do not appear to have been known to Mr. Druery.

For several reasons it is desirable to have a record up to the present time; and the most powerful of these arguments is the confusion that exists. Allied varieties have been found by different persons, and such names as divisolobum, grandiceps, plumosum, polydactylum, cristatum, cruciatum, crispum, etc., have been used over and over again, sometimes with the additional name of the finder ; or, if showing distinct cliaracters, one or two extra names have been added, until we have varieties that can boast of possessing three or four names, such, for example, as Aspidium angulare, variety decompositum-magnificum-polydactylum, and one or two even longer than this. A simple descriptive name of any marked character, such as plumosum, cristatum or crispum, is desirable, or even a compound name that will denote two marked characters like ramo-coronans, sagittato-projectum, or lineare-cristatum, may not be objected to; but a cumbersome string of names cannot be tolerated, no matter how descriptive it may be ; in fact, a name is the symbol by which it is to be recognised, and is not intended to be a description. We can now, by crossing several varieties of ferns, produce all the characters on one frond, and several of these again crossed will give us their combined characters; and this must prove the utter impossibility of a descriptive nomenclature. 
It is always undesirable to change a familiar name; and therefore, in order to create as little alteration as possible,--in those families that are particularly rich in varieties, - a plan has been adopted of dividing the varieties of the species Aspidium angulare, Scolopendrium vulgare, and Asplenium filix-fomina into divisions, groups, and sections, for the distinct varieties are now to be reckoned by hundreds in these species :-

\section{Asplenium Filix-fœmina.}

Division A. Changes in skelcton.

Group I (branched).

Section a ramosum.

,$\quad \quad \beta$ grancliceps.
,$\quad \gamma$ cristatum.
,$\quad \quad \delta$ cruciatum.

Group 2 (dwarfed).

Scction a pumilum.

, $\quad \beta$ crispatum.

$$
\text { Group } 3 \text { (flexuosc). }
$$

Scction a flexuosum.

Division B. Alteration of soft parts.

Group I (subdivision of segments). Group 2 (diminution of soft parts). Section a plumosum.

,$\quad \beta$ clissectum. Section a laxum. , $\quad \beta$ depauperatum.

Groutp 3 (abbreviated pinnx).

Scction a rotundatum.

,$\quad \beta$ linearc.

$\begin{array}{cc}\text { Section } & \gamma \text { laciniatum. } \\ , & \delta \text { lunulatum. }\end{array}$

\section{Scolopendrium vulgare.}

Drvision A. Changes in skcleton.

Group I (branched).

Scction a ramosum.

Sub-section a ramo-inæquale.

Section $\beta$ cristatum.

Sub-section $\beta$ ramo-marginatum.

Scction a truncatum. Sub-section a peraferens.

Section $\gamma$ conglomcratum.

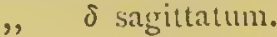

Division B. Alteration of soft parts.

Group I (incrcased development). Section a crispum.

, $\quad \beta$ undulatum.

Grous 3 (surface rough).

Section a muricatum.

,$\quad \beta$ supralineatum.

,$\gamma$ margimatum.
Group 3 (flexuose).

Section a flcxuosum.
Group 2 (narrowing of slicleton). Section a exigrum.

Grout 4 (marrin alteresl). Scction a fissile.

$$
\text { Group } 5 \text { (viariegratcel). }
$$

Section a varicyatum. 


\section{Aspidium angulare.}

Division A. Changes in skeleton.

Group I (branched).

Scction a ramosum.

, $\quad \beta$ grandiccps.

, $\quad \gamma$ cristatum.

Section $\delta$ polydactylum.

Group 2 (dwarfed).

Section a congestum. " $\quad \beta$ alatum.

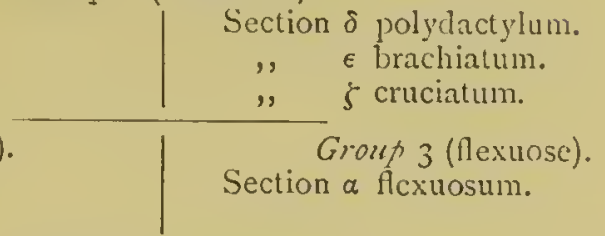

Group 4 (stipitate).

Section $\alpha$ stipatum.

Division B. Alteration of soft parts.

Group I (incrcased development). Group 2 (diminished developmcnt). Scction a plumosum.
,$\quad \beta$ foliosum.
", $\quad \gamma$ pulcherrimum.
" $\delta$ macropinnulum.

Section a laxum.

Group 3 (subdivision of pinnules).

Section a dccompositum.

$\begin{array}{ll}, & \beta \text { acutilobum. } \\ , & \gamma \text { divisolohum. } \\ , & \delta \text { plumoso-divisolobum. } \\ , & \epsilon \text { multilobum. }\end{array}$

Division C. Alteration of outline.

Group I (widened).

Section $a$ deltoideum.

Group 2 (narrowed).

Section $a$ angustatum.

Group 4 (cliangcd development).

Section a rotundatum.

Drvision D. Alteration in colour.

Group I (varicgated).

Section $\alpha$ variegatum.

By the above arrangement the number of names to any one variety is in most instances diminished, being merged into the name of the section. The aim has been to correct the unpalatable names that already exist without destroying their identity.* 'Future names, it is hoped, will be more in accordance with the rules of Botany; and this is important, as the increase in varieties, both by wild

* Mr. Thomas Moorc, whose name will always be receivcd with respect, was (perhaps innocently) the originator of compound names. A Hart's Tonguc having a marginal belt was named by him marginatum, another bimarginatum, whilst a third with a branched head becamc bimarginatum multifidum. This habit becamc chronic with some of our British Fcrn authorities, who declared that a descriptive name, no matter how unwieldy, was the one to adopt. Even the nomenclature of Linnaus and Decandollc was conclemned; and the variety of Polypodium vulgare known as cambricum from the timc of Linnaus (norc than a centmy ago) was altered to plwmosum. Thc author believes that nearly all the members of the Pteridological Society now condemn cumbersomc names. 
finds and by judicious crossing, has never advanced so rapidly as it is doing at the present time.

The nomenclature adopted in this Handbook is that of the late Sir William Hooker, as given in his "Synopsis Filicum," completed by Mr. J. G. Baker, F.R.S., Royal Gardens, Kew. In this work Sir William Hooker has arranged the British species in the following order :-

SUB-ORDER II. POLYPODIACE E.

Tribe 2. DICKSONIEI.

Woodsia ilvensis, $K$. Browin.

," hyperborea, $R$. Browun.

Tribe 3. HyMenophyides.

IIymenoplyyllum Tunbrilgense, Smith.

, $\quad$ inilatcrale, Bory.

Trichomanes radicans, Swartz.

Tribe 4. DavallieA.

Cystopteris fragilis, Bernhardi.

" alpina, Desvaux

(Cystopteris regia, Desvautx).

", montana, Link.

Tribe 6. P'TERIDEA.

Adiantum Capillus-Veneris, Linnaus.

Cryptogramme crispa, R. Browon

(Allosorus crispus, Bermardi).

Pteris aquilina, Limncus.

Lomaria Spicant, Deszastx

(Blechnum Spicant, Smith).

Tribe 8. Asplenie,

Asplenium viride, Hudson.

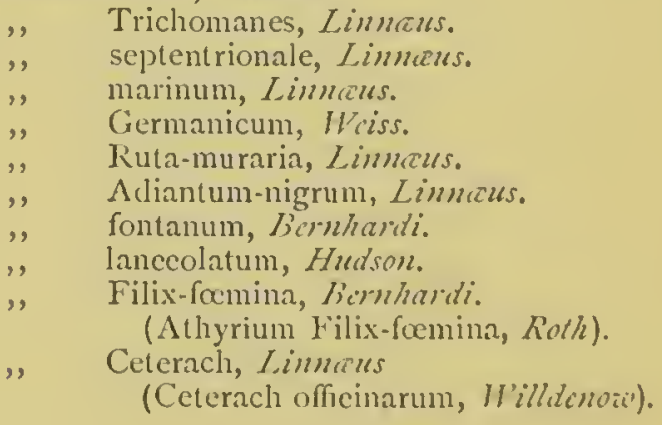

Tribe 9. SCOLOPENDRLi:

Scolopendrium vulgare, Smith. 
Tribe Io. Aspidies.

Aspidium Lonchitis, Swartz

(Polystichum Lonchitis, Roth).

,$\quad$ aculeatum, Szvartz

(Polystichum aculeatum, Rolh).

, angulare, Kïtaibel

(Polystichum angulare, Presl, and included in aculeatum, Szuartz).

Nephrodium Thelypteris, Desvaux

(Lastrea Thelypteris, Bory'). montanum, Baker

(Lastrea montana, Moore, and L. Oreopteris, Bory).

", Filix mas, Richard

(Lastrea Filix-mas, Presl). paleaceum, Don

(Lastrea Filix-mas, Presl, and Aspidium paleaceum, Donov'an).

" propinquum, Lozve

(Lastrea Filix-mas, Presl, and L. propinqua, Wollas(on).

, $\quad$ cristatum, Michaux

(Lastrea cristata, Presl).

rigidum, Desvaux

(Lastrea rigida, Presl).

spinulosum, Desiaux

(Lastrea dilatata, Presl).

Tribe II. PolyPodies.

Polypodium Phegopteris, Linnaus.

,, Dryopteris, Limnaus.

" Robertianum, Hoffmann

(P. calcareum, Smith and P. Dryopteris, var. Bollon).

, alpestre, Hoppe.

", vulgare, Limnaus.

Tribe 12. GRAMMITIDEж.

Gymnogramme leptophylla, Deszaux.

SUB-ORDER III. OSMUNDACEA.

Osmunda regalis, Linnaus.

\section{SUB-ORDER VI. OPHIOGLOSSACEÆ.}

Ophioglossum lusitanicum, Linnaus.

Botrychium Lunaria, Sivartz. vulgatum, Linnaus. 
In Sulvorter I there ase no European representatives

, 2, Tribe I

, 9

$2,,, 4,4$

4, this contains $S$ I known Davallias, none British.

,

$2,$,

5, no European representatives.

$2,$,

6 , out of 62 Adiantums only one is British.

,

,

,

9,

,

,

,

2 , , 7 , none British.

2 , , $S$, out of $2 S_{2}$ Aspleniums I I are British.

2, , 9, Great Britain has one Scolopendrium.

2 , , 10, out of 56 Aspidiums we have 3 , and out of 224 Nephrodiums wc have only 6.

2, ,, I I, Polypodium. There are 393 speeies, of which only 4 are British.

3 , we have one Osmunda.

4 , there are no rcpresentatives in Europe.

5 , none in Europe.

6, Ophioglossum and Botrychium, there are 3 in the United Kingdom and $S$ in Europe.

\section{THE FERNS OF EUROPE PROPER.}

(Natives of this country are distinguished thus *).

Onoclea Germanica, IVilldenozo.

Woodsia glabella, Brown.

Caucasica, J. Smith.

* ", Ilvensis, Brorun.

* ", hyperborea, Brown.

Dicksonia Culcita, L'Héritier. Smitr. Fingland, Wales, and Seotland.

Lapland, S. Tyrol.

Caucasus.

England, Wales, and Seotland.

England, Wales, and Seotland.

Spain. unilaterale, R. Brow'n.

* Trichomanes raclieans, Swartz.

Davallia Canariensis, Smith.

*Cystopteris fragilis, Bermhardi.

* $\quad$, alpina, Desvaux.

* ," Sudetica, A.Br. so Milde.

* ," montana, Link.

* Adiantum Capillus.Veneris, Limnars.

Ethiopieum, Linnaus. "', , Hispanica, Mettenius.

, Szovitzii, Fisch \& Neycr.

*Cryptogramme erispa, $R$. Brozin.

Pteris longifolia, Linnaus.

, Creticn, Limnaus.

,, arguta, Aiton.

* ," aquilina, Linneres.

*Lomaria Sipieant, Disvaux.

Arctic Europe to Pyrenees.

England, Scotland, and Ireland. Norway.

Ireland, Scotland, and Walcs.

Spain and Portugal.

United Kingrdom.

England, and from Sweden to Spaill.

Silcsia, Moravia, and Carpathians.

Seotland, Scanclinavia, and Central Europe.

England, Wales, Ireland, \& warmer parts of Europe.

Spain.

Switzcrland and Southern Europe.

Portugal and Spain.

Italy and Dalmatia.

England, Seotland, Ireland, Spain, Lapland.

Spain, Dalmatiea, Sieily.

Switzerland, Italy, Crete, Corsien.

Portugal.

England, and throughout Europe.

United Kingrdom, and througliout Europe. 
Woodwardia radicans, Smith.

Asplenium Hemionitis, Linncus. viride, Hulson.

Henfferi, Reichardt. Trichomanes, Linusus.

Petrarchæ, De Candolle. septentrionale, Ifoffmann.

Scelosii, Leybiold. marinum, Linuress.

germanicum, Weiss.

Ruta-muraria, Linnaus.

fissum, Kilaibel.

Adiantum-nigrum, Linnęus.

fontanum, Bernhardi. lanceolatum, Hudson. (Athyrium) crenatum, Ru- Norway, Sweden, Lapland. precht.

(Athyrium) Filix-foemina, United Kingdom, and throughout Birnhardi.

(Hemidictyum) Ceterach, England, Ireland; to Spain and Linnaus.

Scolopendrium vulgare, Szuartz.

Hemionitis, Szuarlz. France, Italy, Sicily, Spain, Greece. Aspidiun (Polystichum) Lonchitis, United Kingdom. From GreenSivartz. land to Greece.

(Polystichum) aculcatum, United Kingdom. Througheut Szuartz. Europe.

Nephrodium (Lastrea) Thelypteris, England, Ireland, Scotland. Desvaux. , montanum, Baker. Un 'I hroughout Europe.

,

,

,

,

,

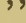

, Filix-mas,

cristatum,

$\because$ " cristatuin, Michanx.

rigidum, Desvaux. England, Spain, Greece, Germany, Siritzerland.

spinulosum,
Destaux

United Kingdom. Europe.

United Kingdom. Europe. ris, Limnins.

Dryopteris, Linnorus.

United Kingdom. P'yrenees. alpestre, Hoppe. Scotland, Lapland, Kussia, Germany, Alps.
Throughout Throughout Laplane] to 
*Polypodium vulgare, Linncus.

Nothochlena lanuginosa, Desz'aux. Maranta, R. Brown.

Gymmogramme P'ozoi, Kunze.

* ,, leptophylla, Disiaux.

*Osmunda regalis, Linnceus.

* Ophioglossum Lusitanicum, Linneus.

* ,, vulgatum, Linnious.

Totryehium simplex, Hitchcock.

, rutaceum, Swortz.

* ", Lunaria, Szitartz.

", tematum, Swarts.

", Virginianum, Siurrls.

", Matricariefolium, †. Brozin. N. Europe. Europe.

S. Europe.

Spain. Europe.

N. Europe.

Scandinaria.

United Kingdom. Throughout

Spain, Greece, Syria.

Jersey. S. Europe.

United Kingdom. Throughout

Guernsey to Mediterranean.

England and Ireland. Lapland, and various parts of Europe.

United Fingdom. From Arctic Europe to Spain.

Inpland to Pyrenees.

Norway to $\Lambda$ ustria.

To the above may be added, from Algeria, Madeira, Canarics, and dzores :-

Onoclea orientalis, Hookm.

Adiantum reniforme, Linnurus.

Cheilanthes pulchella, Bory'.

Asplenium monanthemum, Linncus.

,, sepulchrale, Hook'r.

, furcatum, Thumberg.

$\because \quad$ (Alhyrium) umbrosum, $J$. Smith.

Aspidium (Polystichum) falcinellum, Sivartz.

" ", frondosum, R. Lowe.

Nephirodium (Lastrea) xmulum, Baker.

,

", molle, Deszaux. unitum, R. Brozint

Polypodium (I'hegopteris) drepanum, Hooker.

(iymnogramme (Leptogramme) 'Totta, Schlichtodul.

Acrostichum squamosum, Srinntz.

A more extended account of the Ferns of Europe, and throughout the world, will Le found by referring to "A Geographical Handbook of all the Known Ferns," by Mrs. K. M. Lyell (1870), the above extract being sufficient to show the Ferns of Europe. Reference may also be made to "Casscll's European Ferns," in which the species are described and figured. There are twentynine species not found in this country, out of the serenty European lierns. My list contains forty-fise British species.

+ Incluled in "liuropen Ferms," My Mr. James Britten. 
SUB-ORDER II.

POLYPODIACEÆ.

\section{Tribe 2. DICKSONIEAE.}

\section{THE OBLONG WOODSIA.}

IVOODSIA ILVENSIS. - R. Brown.

A DIMINutive mountain fern with fronds from 2 to 4 inches long. This plant grows in the crevices of damp rocks. The fronds are lanceolate-pinnate, the pinnae being profoundly pinnatifid. The rachis, stipes, and underside of the frond chaffy, and the sori scattered. It is a deciduous fern, and requires growing under a bell-glass. Exceedingly rare, and found at altitudes of from 1,200 to 3,000 ft. Mr. Joseph Sidebothan discovered it in Carnarvonshire; and it has been found in Westmoreland, Cumberland, and Durham, one locality near the Caldron Spout, Teesdale (in an inaccessible place, E. J. L.). In Scotland, near Loch Skene (Rev. IV. Little) to the North of Moffat (P. Gray), hills between Dumfries and Peeblesshire (abundant, Mr. IV. Stevens), near Crieff on Ben Chonzie (the late Professor Balfour), Ben Lawers (Mr. J. Backhouse), Clova Mountains (Sir IV. Hooker). Professor Balfour, Mr. Neill Fraser and myself failed to find it on Ben Lawers.

It occurs in Iceland, Lapland, Norway, Sweden, Denmark, Russia, NovaZembla, Caucasus, the Crimea, Spain, Italy, France, Germany, Switzerland, Hungary, Siberia, Kamtschatka, United States, Canada, the Rocky Mountains and Arctic America, Japan, Siberia, Labrador, Greenland.

No varieties are recorded.

\section{THE ALPINE IVOODSIA.}

IVOODSIA HYPEREOREA.-R. Brown. HAIRY, but not scaly.

Equally rare and scarcely as large as Woodsia Ilvensis, and with shorter pinnæ; growing in similar situations.

Our British recorded localities are Snowdon (Mr. L. Clark) near Crieff on Ben Chonzie, Perthshire, Glen Isla For-

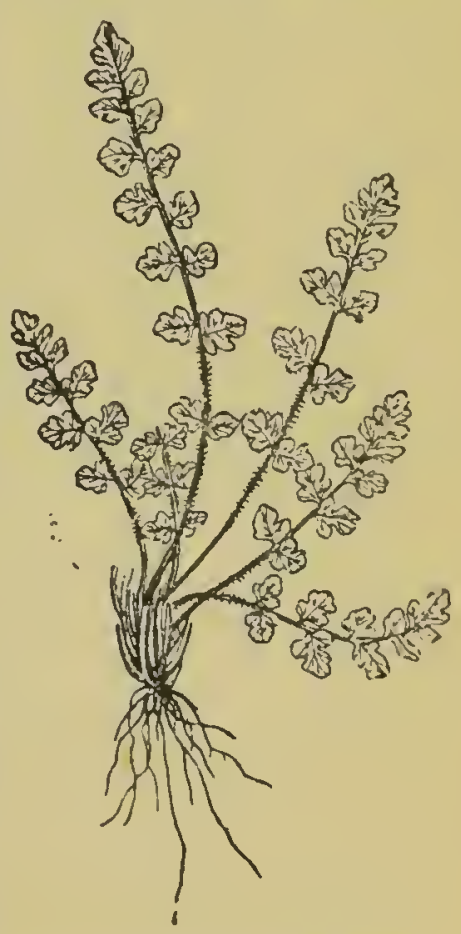

FI.7. 2.-Woodsia hyperborea. 
farshire, and Glen Fiadh, Clova Mountains (the late Professor Balfour), on Ben Lawers (both by Mr. W. Wilson and Mr. Dickson), and between Glen Lochy and Glen Dochart (Mr. J. T. Syme).

It is a native of Finland, Sweden, Lapland, Norway, Russia, Germany, France, Switzerland, Spain, Siberia, Silesia, Tran sylvania, Hungary, Rocky Mountains, on the Himalaya, and in Massachusetts.

There are no varieties.

\section{Tribe 3. HYMENOPHYLLEAE.}

\section{THE ONE-SIDED FILM FERN.}

HYIENOPHYLLUM UNILATERALE.-Bory.

(H. WILSONI.-Hooker.)

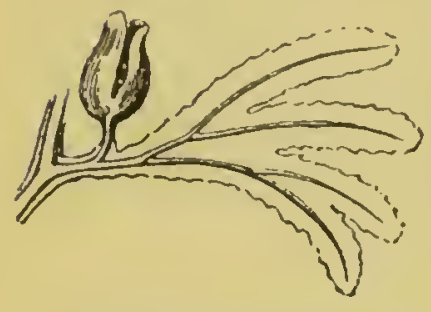

Fig. 3.- Hymenophyllum unilaterale (showing fructification).

A MOSS-LIKE fern which might readily be mistaken for one of the Musci family, having pellucid-membraneous fronds, from $I$ to 6 inches in length. Pinnate, the pinnxe divicled into 3 or 4 lobes. Involucres stalked, the upper margin serrated. Growing in very damp situations amongst moss on the ground or at the base of trees, and on wet rocks.

Found in Cornwall, Devon, Stafford, Salop, Lancashire, York, Northumberland, WVestmoreland, and Cumberland (in the English lakes in at least a score localities), Glamorgan, Brecknock, Cardigan, Carmarthen, Montgomery, Merioneth, and Carnarvon. In 13 Scotch counties, 12 Irish counties, Mull, Arran, Shetland, Orkney, and Harris.

A native of Norway, Faroe, Bourbon, New Zealand, Chiloe, Falkland, Tierra del Fuego, Cape Horn, Tasmania, Cape of Good Hope, and Hermite Island.

The fronds endure for several years, and renew their growth annually. Mr. Gray of Alphington had a plant that had fronds 6 inches long, many of which became branched by subsequent growths.

\section{VARIE:TLS:*}

* I Kinahani, Lowe. Found in 1870 in the Galway Mountains by Mr. R. Kinahan, of the Irish Geological Survey. A long narrow form.

2 Ramosum, Gray. Found in I 867 on Sheep's Tor, I):rtmoor, by Mr. R. J. Gray, and in 1882 on the Mourne Mountains, Ireland, by Mr. R. L. Praeger, length $4 \frac{1}{2}$ inches. Branching sereral times from the main stem.

* All varicties marked thus $(*)$ have received 1 st class Certificates from the Royal Horticultural Society or Royal Botanic Socicty. 


\section{THE TUNBRIDGE FILM FERN.}

HYMenophyllum TUNBRIDGense.-Smith.

A SOMEWHAT similar fern, with broader fronds and having more divisions in the pinnx, sometimes being split into 8 or 10 lobes. Less common than $H$. wilaterale.

Found in Cornwall, Devon, Somerset, Kent, Sussex, Lancashire, Cheshire, Yorkshire, Cumberland, Westmoreland, Glamorgan, Brecknock, Merioneth, Carnarvon. In 5 Scotch and 6 Irish counties. Valentia, Mull, Bute, and Arran.

A native of Norway, Sweden, France, Germany, Italy, Belgium, India, Madeira, Azores, Mauritius, Chili, Brazil, New Holland, New Zealand, Tasmania, Valdi-

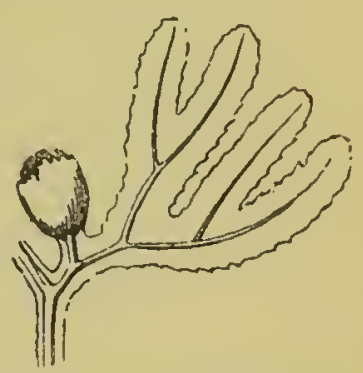

FIG. 4.-Hymenophyllum Tunbridgense (showing fructification). via, and the Cape of Good Hope.

The fronds paler in colour than those of $H$. unilaterale. The involucres without stalk and the upper margin not serrated.

\section{VARIETY.}

latifolium, Praeger. Found in 1882 at Narrowwater, county Armagh, by Mr. R. L. Praeger. $5 \times 1 \frac{3}{4}$ inches (in widest part), lower half depauperate and very narrow, above broad and plumose.

The Film Fern succeeds well when fastened to a large stone with wires, provided the stone is kept wet.

Both the Film Ferns are often found growing together, though "H. unilaterale is the commoner of the two. In Hooker's "Synopsis "Filicum," the one-sided Film Fern is considered as a variety of the Tunbridge Film Fern.

\section{THE BRISTLE FEIRN. \\ TRICHOMANES RADICANS.-Szuartz.}

ONE of the Filmy ferns, and the only Trichomanes that is a native of Great Britain ; a genus that abounds in the Tropics. It grows on wet rocks in mountainous districts, delighting in the spray of a waterfall. The fronds vary in length from six to sixteen inches, are membranaceous, pellucid, smooth, and olive-green. The fronds, if uninjured, remain on the plant for several years. It is ovatetriangular in form, and feathery in appearance. Cannot be confused with any other fern.

Bolton saw it in 1758 growing in abundance near Bingley in Yorkshire, but in $17 \varepsilon_{2}$ could only find one plant. The late $M r$. Backhouse found it about thirty years ago tolerably abundant and lourishing luxuriantly in several places, extending over several miles in Wales, but the locality has been kept secret from a dread of its exiermination by collectors. Mr. Backhouse gave me a 
plant, which is now a large specimen, and proves a distinct variety. More recently Mr. Rowbotham again found this fern in Wales. It is to all intents an Irish fern, and is much more rare than it used to be. Dr. Mackay found it in Hermitage Glen; Dr. Stokes, at l'owerscourt Waterfall; Glendine, by Mr. R. Ball; Glanbour, by Mr. J. A. Fisher; Temple Michael Glen, by Mr. D. Murray; Ballinhasy Glen and Bandon, by Mr.S. P. Woodward; Clashgariffe, by $\mathrm{Mr}$. J. Drummond; Glandore, by Dr. Allman; Bantry and Curaan Lake, by Mr. C. C. Babington; Kildorrery, by Mr. J. Carrol; Blackwater, by Dr. Kinahan; Cumailte Mountains and Torc, Killarney, by Dr. Mackay; Island of Valentia, by Miss $\mathrm{H}$. Blackburne; Cromaglaun, by $\mathrm{Mr}$. W. Christy; Mount Eagle, by Mr. D. Moore; Gortagaree, by Dr. Taylor; and Blackstones, Glouin, Caragh, Inveragh, by Mr. W. Andrews; and in Donegal (1884), by Mr. P. Mahoney. It has also been found in the island of Arran, Scotland, by Mr. W. B. Simson, of Edinburgh.

A native of Spain, Teneriffe, Canary, Madeira, Azores, Algeria, Jamaica, Martinique, Mexico, Panama, New Granada, Brazil, United States, Venezuela, Galapagos, Sandwich and Society Isles, Northern India, and Polynesia. I have large plants that have been growing in pans for forty years, and my special mode of culture is worthy of being copied. Large pans, well drained, have a compost of freestone, lumps of peat, and silver sand, the stone predominating; on this the rhizomes are fastened. A canal of water surrounds each plant.

My Filmy Ferns are kept in a pit five feet deep, covered at the top with frame lights that are lifted daily (sometimes twice a clay), for the purpose of wetting the fronds with a fine spray in imitation of a shower. The plants are elevated on stands (about six inches) to keep them above any water that might drain into the pit in very rainy weather. The lights are shaded with the "green Willesden scrim" (from the Willesden Waterproof Paper Works). It is just the shade ferns delight in ; cheap and durable, and in short nothing better could be desired for ferns either in houses or out of doors. It is now more than twenty years since these ferns have been repotted.

VARIETIES.

* Alabamense, Birkenhead. A dwarf American variety, very distinct and almost strap-shaped. $4 \times$ I inclies.

*2. alatum, Clapham. Found in Ireland by the late $M r$. Clapham, conspicuously winged. $12 \times 6$ inches.

3. Americanum, Birkenliend. Pinnules broad. An American variety. ro $\times 4$ inches.

4. Andrewsii, Ifone: Found in Glouin Caragl, Ireland, by the litte Mr. William Andrews, from whom I received a portion of the origrinal plant in 1864 , fronds narrower and more lanceolate, and pinnie more distant. 'The involucres are sessile and quite sunk in the frond. $13 \times 7$ incles.

5. Backhonsei, Lowe.

Wales, some 35 years asro.

Found by Mr. Backliouse of York, in 
dilatatum, with less divided and shorter pinnules, broadly winged, fronds a shining dark green, sori prominent. $13 \times 7$ inches.

6. Cambricum, Ashtor. Found by the late Mr. Rowbotham (of Manchester) in Wales. The tip of the frond and pinna longer and narrower than in Backhousei. $9 \times 4 \frac{1}{2}$ inches.

*7. crispum, Lowe, (crispum-cristatum, Jones). Found in the Killarney district in $I \$ ; 2$ by the late Colonel A. S. H. Lowe (Gosfield Hall), very distinct, crisp, and irregularly branched. $10 \times 5$ inches.

8. cuneatum, Kinaham. Sent to me in I870 by Mr. Kinahan (Koebuck Park), fronds wedge-shaped.

9. densum, Stunsfield. A pretty densely fronded form. Io $\times 3 \frac{1}{2}$ inches.

Io. dilatatum, Backhouse. Found in Ireland by Mr. Backhouse, and named for its resemblance to Hymenophyllum dilatatum. I $3 \times 7$ inches.

I I. dissectum, Stinsfiel.. Broad and tapering to a point, finely divided; beautiful. I $5 \times 6 \frac{1}{2}$ inches.

12. dissectum-cuneatum, Birkenhea!. Not unlike dissectum, but wedge-shaped, and scarcely differing from cuneatum.

13: proliferum, Druery (bulbiferum, Jones). Found at Killarney : bearing bulbils. In the possession of Professor Morris of Isath ; with him it has not borne bulbils.

\section{Tribe 4. DAVALLIEAE.}

\section{THE BRITTLE BLADDER FERN.}

\section{CYSTOOPTERIS FRAGILIS.-Bernhardi.}

\section{A COMMON de-} ciduous species, from the sea level to the summit of Ben Lawers $(4,000$ $\mathrm{ft}$., where its fronds have only a height of 2 inches), growing on rocks and walls. The fronds

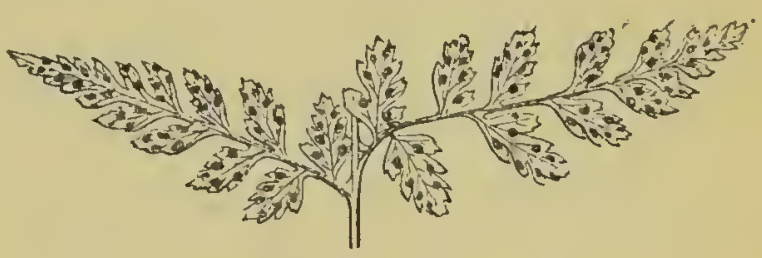

Fis. 5.-Pinna of Cystopteris fragilis (showing (ructification).

sometimes attain a length of $\mathrm{I} 2$ and occasionally is inches. Colour a dull green, Growing in spreading tufts, and cannot be mistaken for any other fern. It occurs throughout Europe and in many other parts of the world.

\section{VARIETIES.}

r. adiantoides, Lowe. Found near Dundee by myself. It is a large-growing, much-clivided variety, with broad pinnze and pinnules (the superior basal one very large).

2. angustata, Smith. Found in Devon, Derby, York, Cumberland, Westmoreland, Carnarvon, Monmouth, Edinburgh, Perth, and Sligo. Length of frond 12 inches. Slender and very narrow, ending both in the pinnæ and the fronds in long taper points. 
3. crispa, Lowe (Dickieana crispa, Tait). A dwarf variety found near Aberdeen by Mr. Tait. A copy of Dickieana with crisp fronds.

4. cristata, Lowe. A variety with crested fronds raised by $\mathrm{Mr}$. C. Elworthy at Nettlecombe. In 187 I Mr. R. Moule of llfracombe raised another with fronds $S$ inches in length in which the fronds are very variable, sonetimes symmetrically crested, at others capitate, ramose, or ramose and crested. Mr. Keale of Wantage and Mr. Mapplebeck of Birmingham have raised others, and Mr. J. M. Barnes has found it at Sedgwick.

5. decurrens, Moore. Found near IVemyss Castle, Fifeshire, by Mr. Tait of Edinburgh. Pinna deflexed and distant, pinnules decurrent; characters intermediate betwcen Dickieana and the normal form.

6. dentata, Hooker. A not uncommon variety. Length 4 to 8 inches, narrow, pinnules somewhat confluent and blunt toothed.

7. Dickieana, Moore. Found near Aberdeen by Dr. Dickie, near 1) unkeld by Br. Balfour, and Isle of Arran (Galway), by Mr. D. Noore of Glasnevin. A dwarf form. Pinnx twisted, deflexed, and over-lapping, pinnules crowded and overlapping. More recently at Mountain near Chepstow, by Mrs. Curre, and in S. Wales by Mrs. Bagnall Oakeley.

8. furcans, Moore. Found at Killin by Mr. S. O. Gray, and on Clova by Messrs. Stansfield. It is of the normal type, with the apex and a portion of the pinna forked.

9. intcrrupta, Wollaston. Found at Windermere by Mr. 1. Huddart. Very narrow; pinnx variable, much depauperated, and some wanting; segments deeply cut and apex truncate. A very singular variety.

io. lineare, O'K'elig'. Length of frond 12 inches. A large, lax, very narrow frond, with linear segments. Found in the Burren, county Clare, by Mr. P. B. O'kelly of Glanarra House, Ballyvaughan.

11. minutissima, Jones. Origin unknown. A diminutive bushy variety, crowded with fronds, but never excecding 2 or 3 inches in height. It came into the possession of Colonel Jones with other ferns.

12. obtusa, Mfoorc. Found in Scotland by Mr. A. Tait, near I'hitby by Mr. Clapham, Llyn Ogwen by Mr. S. O. Gray, and in the Lake district by Mr. Clowes and Mr. Wollaston. Length I inches, lanceolate, pinnules blunt.

13. quadrata, Claphom. Found near Rydal by Mr. A. Clapham. Length 6 inches, basal pinna remote, pinnules rounded, and a portion, especially the basal ones, flat. Minutely dentate.

14. sempervirens. Found at Tunbridge Wells, and in Deron, but supposed to have been introduced from Madcira. It has a short creeping rhizoma, and in a cool greenhouse is evergreen.

15. truncita, Low' (truncata-intermpta). A truncate form, differing from interrupta in having mucl broader, clilated, and rounded apices. 
16. Wyense, Lozee. A very alpina-looking form, found on the rocks along the Wye by Major Cowburn ; dwarf, pinne and pinnules crowded; more nearly resembles $C$. alpina than any other variety.

\section{THE ALPINE BLADDER FERN. \\ Cystopteris ALPINA.-Deswaux. \\ (POLYPODIUM REGIUN.-Linnaus.)}

A RARE British species, found at the end of the last century growing on a wall at Leyton in Essex. This is the only well-authenticated locality in this country; and the plant has now ceased to exist there. Dwarf for a Cystopteris, and more finely divided than C. fragilis. It is a native of the Alps, and is also found in Spain, Italy, France, Belgium, Switzerland, Greece, Hungary, Sweden, and Asia Minor.

There are no varieties to be recorded, and the species is thought to have been introduced.

\section{THE MOUNTAIN BLADDER FERN.}

\section{CrSTOPTERIS MONTANA.-Link.}

A VERY distinct, fragile, triangular fern, with tripinnate fronds, and very long, slender stipes. It has a lengthy creeping rhizoma, and flourishes well under cultivation, if sufficient room is given for the growth of the rhizoma. Sori copious, medial, and indusiate.

First found in 1836 on Ben Lawers, in Perthshire, by $\mathrm{Mr}$. IV. IVilson.

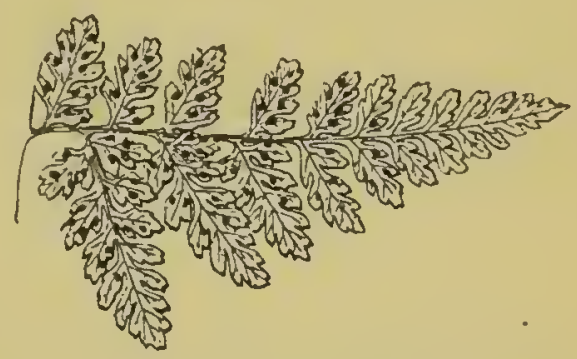

FIG. 6.-Lowest pinna of Cystopteris montana (showing fructification).

In $187 \mathrm{I}, \mathrm{Mr}$. P. Neill Fraser and myself visited this spot, and found that it was still abundant in that habitat. Mr. J. Backhouse has also found it in Canlochen, at the head of Glen Isla (Clova Mountains). It grows on moist ledges of rock, on mountains, and is one of our rare British species.

Abroad, it is a native of Norway, Sweden, Denmark, Lapland, France, Spain, Italy, Germany, Switzerland, Hungary, Kamtschatka, and in the Rocky Mountains.

There are no varieties.

\section{Tribe 6. PTERIDEAE.}

\section{MAIDEN HAIR FERN.}

AdANTUM CAPILLUS-VENERIS.-Linnchus.

AN unmistakable species, and the only one of a large exotic zenus that is found in Great Britain. 
The fronds are bipinnate, and in some varieties tripinnate, varying in length from a few inches to 2 feet, according to locality.

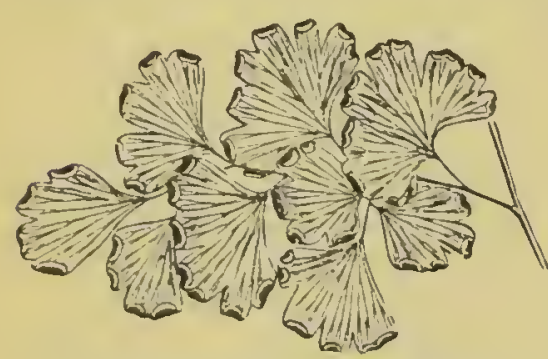

Fig. 7.- Portion of frond, under side of Adiantmu Capillus-Veneris (showing fructification).

In some parts of the Burren, in County Clare, it assumes its maximum size. The sori are situated on the apex of the lobes, in marginal lines, the indusium being the reflexed portion of the apex of the lobe. The stipes and rachis are slender, eboneous, and shining. The fronds are thin, membranous, and a vivid green. fern.

It is a beautiful and graceful

Found in Cornwall, Devonshire, Somersetshire (Clevedon, by Mr. L. H. Grindon; Cheddar, by the Rev. W. H. Hawker; and Combe Down, near bath, a single plant, E. J. L.)†; Clea Hill Shropshire, by Mr. WVestcott; Glamorgan and Barry Island (E. J. L.) ; Galway, Kerry, Clare, Ǩincardineshire, Jersey, Guernsey, Isle of Man, and Arran Isles.

It is a native of very many temperate and hot countries, occurringr in France, Spain, Portugal, Italy, Switzerland, Belyium, Greece, Turkey, Jersia, Java, China, Dalmatia, India, Syria, Siberia, Caucasus, Egypt, Abyssinia, Algiers, Madeira, Canary, Azores, Madagascar, Natal, Alabama, California, Texas, Mexico, Guatemala, Caraccas, Chili, Trinidad, St. Vincent, Jamaica, Sandwich Islands, etc.

\section{VARIETIES.}

*1. admirabile, Lorve. Raised by myself. Length, 2 feet. Stout and distinct; and no Adiantum makes a better specimen. Liasal pinnx descending.

*2. angustatum, Lowe (bulbiferum, Claphami). Divarf, and when sent to me by the late Mr. Clapham, the fronds literally covered with young plants. There were no perfect spores; and had it come under the keen eyc of Mr. Druery, he would have seen another case of apospory?

*3. autumnale, Lorve. Raised by myself. Slender fronds, golden in colour. Length, 18 inches.

4. Clorinda, Lozue. Raised by myself. Length, 20 inches. Robust, with upright habit. Stipes long, stout, and eboneous. Pinnules cuneate, the ultimate one not larger. Inclusium datk and conspicuous.

5. Cornubiense, Moore. Found in I868, near Hayle (Cormwall), by Mr. H. H. 'Trevethick. A latro plumose varicty. l'innule's deeply divided into ten or twelve narrow fringed divisions.

*6. Daphnites, Lozve. A remarkable form, raised from spores from a frond giren to me by Sir Joseph Hooker, about twenty- 
three years ago. Length, 6 inches. Erect, pinnæe large, and so crowded together as to appear crested. Costa wavy.

7. depauperatum, Clapham. Raised by the late Mr. James. Length, 12 inches. Much cut and depauperate.

8. digitatum, Moore. Raised by Mr. O'Brien.

9. fimbriatum, Jones. Raised in 1872 by Miss Baker. Length 9 inches. Distinctly fimbriate.

Io. fissum, Moore (alcicorne?). Dwarf. Length, 6 inches, Pinnules cut into shreds. A great departure from the ordinary form.

II. Footii, Lowe. Found in County Clare, by Mr. J. F. Foot (near Ballyryan). Length, 24 inches. Pinnules varied in length, some nearly an inch wide.

*I2. formose, Lorve (perfectum, Padley). Found in the Crimen, and sent to me by Sir Joseph Hooker. Very slender and minute in all its parts.

I3. grande, Moore. A fine variety, sent to me by Mr. Jannock. $8 \frac{1}{2} \times 2 \frac{3}{4}$. Ultimate pinnules large.

* I4. imbricatum, Lowe. Raised by myself. Dwarf and imbricated.

15. incisum, Moore. Found in several localities, but a much more distinct form (incisium-Footii, Lowe) was found in County Clare by Mr. J. F. Foot. Length, 15 inches. Pinnules large and much incised.

16. Jonesii, Lowe. Found in the Salt Spring Islands, by Mr. G. Lucas. Distinct, stiff, and robust, with an erect, close habit. Pinna thick and leathery, ascending, trapeze form, except the ultimate ones. Stipes like polished ebony.

* 7. kalon, Lowe. Raised by myself. $12 \times 6$ inches (broadest at base, and gradually narrowing). Pinnules rounded, large, and orerlapping.

18. luminare, Lowe. Raised by myself. A golden variety.

19. magnificum, Fraser: Large, bold, making a handsome plant.

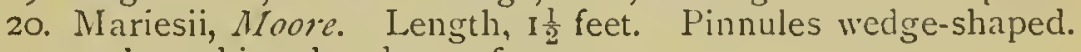
A strong-branching, handsome form.

2 I. Moritzianum, Moore. A large form.

*22. multiceps-dentatum, Lowe. Raised by myself. Length, Io inches. Branching.

*23. nobile, Lowe. Raised by myself. Length, 12 inches. Slender, pinnules small, fronds golden yellow.

24. O'Brienianum, Birkenhead. Length, I foot.

*25. optandum, Lorve. Raised by myself. Length, 2 feet (stipes, I foot). Narrow. Pinnae distant. Pinnules small and cuneate, distinct.

26. Padleyi, Lowe. Found in Devon, by the Rev. C. Palley. Length, 5 inches. All the pinnules concave.

27. Pixyeidon, Lowe (plumosum, Jones). Found in 1869 , in Cornwall, by Mr. J. Dadds. Length, 9 incles. Very feathery, but irregular. Pinnules here and there projecting in long sharp pointed strips.

28. plumosum, Moore. Found in North Devon. Differing from Cornubiense in having long acute Pixyeidon-like projections. 
29. ramulosum, Moore. Found in Ireland. The main rachis dividing near the top, and forming a tuft of short branches.

3o. rotundatum, Moore. Found in the Isle of Man, by Mr. T. G. Rrlands. Frond, narrow ; basal pinnules, round.

*31. spectabile, Lowe. Raised in 1872 by myself. Length. 12 inches. Very large incised pinnules, a close copy of Farleyense, Mir. Elworthy, of Nettlecombe Court, has sent me a seedling that is identical.

32. undulatum, Moore. Length, I foot. Fronds, undulate.

\section{THE ROCK BRAKE.}

\section{CRYPTOGRAMME CRISPA.-R. Brotun.}

\section{(ALI.OSORUS CRISPUS.--Bernhardi.)}

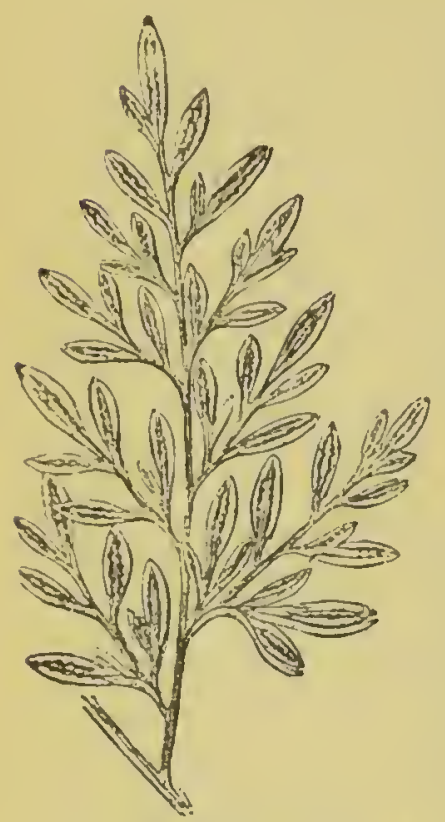

FIG. 8.-Cryptogramme crispa (showing fructification).

THIs fern is also called "the Parsley" Fern," from its general resemblance to Parsley.

There are two kinds of fronds, the fertile and the sterile ; the former, erect with linear oblong pinnules; sori malginal, and eventually confluent.

This dwarf elegant fern is found amongst loose stones (not limestone), on the sides of mountains, and in the North. West of England is so abun. dant as to look like hill-side pastures at a distance. It cannot be confused with any other fern.

Exceedingly abundant on the mountains of Northumberland, Cumberland, Durham, and Westmoreland. Abundant on the hillside of Lothrigg Fell, at the Head of Windermere. It is also found near Lancaster, Settle, Ingleburgh, Cronkley Scar; Wensley Dale, Fountain's Fell. In Derbyshire, Shropshire, Somersetshire, and Worcestershire. In Wales, in Carnarvonshire, Montgomeryshire, Denbighshire, Merionethshire, and in Glamorganshire (though rare). In Scotland it is found in almost every county; whilst in Ireland it only occur's in Down, Antrim, and Louth.

Abroad, it is a native of France, Italy, Spain, Germany, Norway, Sweden, I)emmark, I apland, Switzerland, Hungary, and at Sitka, in North-IVest America.

Although a mountain fern, and found in Scotland at the height of 3,450 fect, in Lancashire it flourishes almost at the sea level.

Several times I have received varieties, and have collected them myself, but none were permanent. There is, however, a 
crested variety (cristata, Druery), that was found at Seathwaite, in 1874 , by the Right Hon. R. A. Cross, whieh has retained its mosslike cresting. Of it Mr. Druery remarks : "This variety is more tender than the normal form."

\section{THE COMMON BRACKEN. \\ PTERIS AQUILINA-LinnCeUs.}

THIS is a well-known fern, growing up in single stems like a tree from its ereeping subterraneous caudex. No other fern is like it. The fronds vary, aecording to favourable or unfavourable circumstances. It is only 4 inehes on the summit of Hellvelyn ; and I have measured it 12 feet on Longridge Fell. Usually it is from 3 to 5 feet. Deciduous, and fructification marginal.

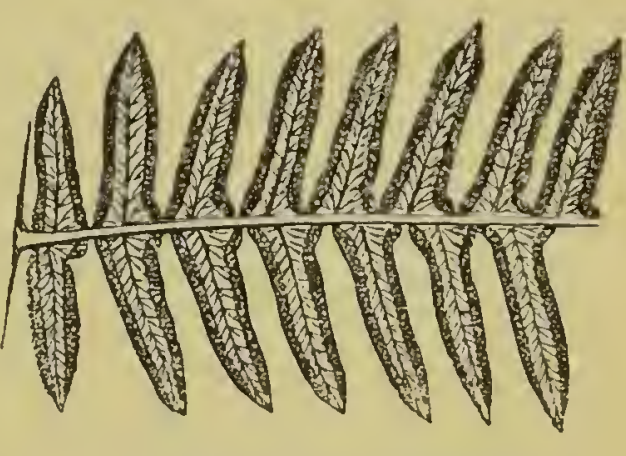

Fig. 9.- Portion of pinna of mature frond, under side, of Pteris aquilina.

The most abundant British fern, and also very common throughout Europe, as far north as Lapland.

There are a few distinct varieties :-

I. attenuata, Moly. Found in North Devon, in 1870 , by Mr. J. Moly. Length of frond, 2 feet 6 inches.

2. Barnesii, Lowe (cristata, Wollaston). Found in Lancashire, in 1874 , by Mr. J. M. Barnes. Height, 3 feet. An interesting crested variety.

3. eongesta, Wolluston. A eongested form. Found in Westmoreland, in 1872 , by Mr. Hindson.

4. crispa, Barmes. Found at Arnside, by Mr. J. M. Barnes. The pinnules crisped.

*5. eristata, Moore. Found in Derbyshire, in 1872 , by Mr T. Glover; at Langdale, by Mr. J. M. Barnes; and recently at The Héndre, by Mr. Comber. Height, 3 feet. Branch crested.

6. fureans, Lowe. Found near Birmingham, by Mr. F. A. Fdelsten, with irregular pinnæ and pinnules. A portion fureate, and the apex multifid.

7. glomerata, Bumes (flexuosa, Wollaston; ineurva, Moore). Found in Westmoreland, in 1864 , by the late Mr. Jacob J. Jones. A conglomerate form.

*8. grandiceps, Moore. Raised from spores by Mr. A Clapham, Mr. J. E. Mapplebeck, Mr. Forster, and others. This eapitate variety is raised from cristata, but grandieeps is sterile. A singular variety. Length, 2 feet.

9. Hartfieldii, Lowe. Raised by Mr. J. E. Mapplebeek. A good eross between incurva and eristata. 
*Io. incurva, Mupplebeck. Raised by Mr. J. E. Mapplebeck. An incurved form.

*I I. Mapplebeckii, Lowe (grandiceps Mapplebeckii, Mapplebeck). Raised by Mr. J. E. Mapplebeck. A very fine grandiceps.

I2. multifida, Barnes. Found at Levens, by Mr. J. M. Barnes, and at Windermere, by $\mathrm{Mr}$. F. Clowes.

*13. pendens, Lowe (grandiceps depauperata, Druery). An accidental marvellous hybrid, recently raised by Messrs. Birkenhead. A depauperate grandiceps with a conspicuous weeping habit. Length, 2 feet.

I4. polydactyla, Moore. Found by the late Mr. Glover, of Manchester. The ends flatly crested.

I 5. ramo-cristata, Mapplebeck. Raised from spores, in I $87 \mathbf{I}$, by Mr.J. E. Mapplebeck. Height, I foot. Both branching and crested.

16. variegata, Barnes. Found at Windermere, hy Mr. F. Clowes; near Chepstow, by myself; near Linton, by the late Colonel Jones; and near Nettlecombe, by the late Mr. Elworthy. A subpermanent form. More golden some years than others. MIr. WV. H. Phillips appears to have found a well variegated form in Ireland, of which I have received prothalli from lim.

The common Bracken can only be safely transplanted in winter, when the fronds are below the ground; and even then it is the safer plan to keep them in a hothouse until established. When grown in pans, care should be taken to keep them from frost, for, although hardy enough, if they become frozen, they are certain to perish.

\section{THE HARD FERN. \\ LOMARIA SPICANT:-Desactux. \\ (BLECHNUM SPICANT.-Simith.)}

A Common fern throughout the United Kingdom, from the sea level to a height of 4,000 feet, growing in heathy or stony situations where there is moisture. Abundant throughout Europe, extending from Lapland in the North, to Madeira.

An evergreen, and easily grown if not neglected.

Sterile and fertile fronds different; the latter larger. Sterile fronds spreading; fertile, erect and narrower. Length, from 4 to 30 inches. Colour, rich deep green coriaceous, and pectinatcly pinnatifid.

Unlike all other British ferns.

$V \wedge R I E T I S$.

I. Aireyi, Lore (serratum Airey, No. 2, Wollaston). liaised by Mr. Airey. Bipinnatifid to bipinnate fronds, $2 \frac{1}{2}$ inches wide, not unlike cambricum in l'olypodium vulgare.

2. Aitkeniana, Moore. A grand bariety, with luge branching heads.

3. anomala, Hoore. Found in many places. Fronds all fertile. Length, 12 inclies. A small form found at Beddgelert. 
4. anomala-multifida, Moore. Found at Rydal, in 1867 , by Mr. IV. Crouch. Fronds all fertile and crested.

5. apiculata, Moore.

6. Bella, Sim. Found at Hutton Roof, in 1864, by Mr. Jacols Jones. Texture thin.

7. binervio-striata, Barnes. Found at Langdale in I875, by Mr. T. Airey.

8. Boltoni, Lowe (projectum Boltoni, Barnes). Found on Borwick Moor, in 1873 , by Mr T. Bolton. A remarkable variety, irregularly crested.

9. cladophora, Moore. Curving, branchinr, and cresting.

10. Claphami, Lore (platypteris, Clapham). Found at Ilkley, in 1863 , by the late $\mathrm{Mr}$. Clapham. A splendid leafy variety. Length, 5 inches.

I1. Concinna, Moore. Found in valley of Conway, Marwood, and Barnstaple. L,ength, 9 inches. See Drueryi, a better form.

12. conferta, Cluphum. Found at Ilkley, in 1863, by the late Mr. Clapham. Pinne crowded and imbricated.

13. congesta, Barmes. Found in Wastdale, in 1876 , by Mr. IV. Crouch ; and on Dartmoor, by Mr. Druery. Dense and congested.

I4. coronare, Love (cristata, Wollaston). Found in Kent, in I853, by Mr: G. B. Wollaston. $9 \times 1$ inches. Crested, having a capitate head 4 inches wide.

I 5. crenato-congesta, Barnes. Found in Patterdale, by Mr. WV. Foster:

16. crispa, Bames. Found in Langdale, in 1872, by the late Mr. J. M. Barnes, and near Tunbridge IVells, by Mr. G. B. IVollaston. Pinnx broad and undulate.

I7. crispata, Barne's. Found in Wastdale, in 1876 , by Mr. IV. Crouch. Crispy.

I8. crispissima, Druery. Dwarf, congested, and much crisped.

19. cristata, Moore. Found near Tunbridge Wells, by Mr. G. B. Wollaston; in Yorkshire in 1860 , by Messı's. Stansfield, etc. IVell crested ferm. Fertile fronds, $18 \times 1$ inches; sterile $9 \times 1 \frac{1}{4}$ inches. A crested capitate head. Another fine form was found at Orrest Head, in 1872, by Mr. T. Airey.

20. cristato-gracile, Barnes. Found at Red Bank, in $1 \mathrm{~S}_{5}$, by Mr. W. Crouch. Narrow, delicate, and crested.

2I. Crouchii, Lowe (subserrata Crouchii, Bames). Found at Grasmere, in 1860 , by Mr. IV. Crouch. A robust crenate ferm.

22. curta, birmes. Found in I87 I, in Dumfries, by MIr. IV. Foster. A narrow decumbent variety, $10 \times 0 \frac{1}{2}$ inches.

23. dentigera, Moore. Found at Windermere, by Mr. F. Clowes. Defective. $12 \times 1 \frac{1}{2}$ inches.

*24. Drueryi, Lotue (concinna, Druery). Found on Exmoor, in I $88 \mathrm{I}$, by Mr. C. T. Druery. Beautiful; like a narrow fringe of beads. 25. elegans, Moore. Found in Scotland by Mr. A. Tait. Pmna, lobate.

26. gigantea, Lowe. Found at Totnes, in 1865 , by Mr. IV. Edwards. $\quad 16 \times 3 \frac{1}{2}$ inches. 
27. heterophylla, Wollaston. Found in Wastdale, in 1876 , by Mr. WV. Crouch, and also by others. Fronds irregular.

2S. Hodgsonx, Lowe (trinervium Hodgson, Uruery). Found on Kirkby Moor, in the Lake district, by Mrs. Hodgson. A very good brachiatum.

29. Hodgsoni, Lowe (multifidum Hodgsoni, Barnes). Found at Torver, in 1868 , by Mr. J. K. Hodgson. A neat crested variety. 30. Huddartii, Lozve (cristatum Huddart, IVollaston). A fine heavily crested fern, found at Windermere, by Mr. J. Huddart.

31. imbricata, Moore. Found in 1870 , at Lake Bank, by Mrs. Hodgson, and by others. Congested, segments overlapping.

32. imbricato-cristata, Dmery'. lmbricate, and neatly crested.

33. imbricato-erecta, Stansficld. Found by Mr. Halstcad. A pretty fern.

34. incisa, Burnes (gracile, Crouch). Found in 1874 , in Rossshire, by Mr. IV. Crouch. $10 \times 2$ inches. More depauperate at the base than serra.

35. interrupto-trinervia, Phillips. Found in 1879 , in County Down, by Mr. W. H. Phillips. $6 \times 0 \frac{1}{2}$ inches. A depauperate trinervium.

36. Kidwillyense, Lorve (ramo-cristata, Stansfield). Found in I876 near Kidwilly, Carmarthenshire, by Mr. WV. H. Maunder. Differs from retmo-cristata in being bunch-crested and clwarfer, $6 \times 0 \%$ inches; width of head, 5 inches.

37. Kinahani, Lowe (cristatum, Moore; ramosa, Kinahan). Found in Ireland by Mr. Kinahan. Branching and curly crested.

38. Kitsone, Lozve. Found near Ashburton, by Miss Kitson. Pinna crimped, bending, and depaupcrate; widest near the apiccs. Length 5 inches.

39. lancefolia, Wollaston (sub-furcato lancefolium, farnes). Found near Tunbridge Wells by Mr. J. B. Wollaston; and in Langdale, in 1875 , by Mr. T. Aircy. A narrow distinct form.

40. lineare, Moore (rolundata, Wollaston). Found on Witherstack, Westmoreland, in 1862, loy the late Mr. J. M. Barnes. $12 \times 0.1$ inches. Remarkably narrow.

41. Iongidactyla, Wollerston. Found at Brigstecr, in $1 \$ 62$, by Mr. A. B. Taylor. Segments of crests long.

42. majus, Moore. Found near Nettlecombe by the late Mr. Elworthy. A large form.

43. Maunderi, Stansficld (glomeratum, Wollaston). Ratised in 1878 by Mr. W. H. Maunder. A glomerate form, $4 !$ inches long.

44. minima-interrupta, Clapham. Found at llkley; in $186_{3}$, by the late Mr. Clapham.

45. Monkmani, Stansfield. lrregular, flexuose, apex multifid.

46. multifida, Mnore. A crested form found at Windermere by $\mathrm{Mr}, \mathrm{F}$. Clowes, and by others.

47. Multiforme, Woilleston. Found on Bethecar Moor, in I86?, by Mrs. Wilson. Fronds various.

48. multifurcata, Monre. Found near P'enryn, by Mr. F. Symons. Fronds many times forked, occasionally brachiate. 
49. obovata, Stansfield.

50. obtuso-multifida, Barnes. Found at Rydal, in 1873 , by Mr. IV. Crouch. Crested pinnæ, short.

51. Padleyense, Lowe. Found at Exmouth, by the late Rev. C. Padley. Lower half simply winged, about $I \frac{1}{2}$ inches wide-serrate.

52. paradoxa, Jones. Found in Banisdale, in 1877 , by Mr. G. Whitwell. Three rows of pinnæe.

53. parviceps, Barnes. Found at Boustead Gates, in I 868 , by Mrs. Hodgson. Small stellate crests.

54. plumosa, Barnes. A grand variety, raised by Mr. T. Airey.

55. polydactyla, Moore. Found in North Devon by Mr. C. T. Druery. Normal in size, and polydactylous.

56. projecta, Moore. Found in Cumberland, in 1862 , by the late Mr. J. M. Barnes, and near Ben Lawers by Mr. Stansfield. Depauperate, with here and there projecting normal pinnæ. Length, 9 inches.

57. projecta-ramosa. Ramose.

*58. ramo cristata, Wollaston (flabellata, Stansfield). Found at Helmsley, Yorkshire, in $\mathbf{1 8 6 5}$, by the late Mr. Monkman. A fine branching variety, the apices of the segments crested. Fertile fronds, I 4 inches; width of head, 8 inches. Sterile, 8 inches; width of head, 8 inches. Mr. Druery has raised a more robust variety.

59. ramo depauperata, Stansfield. Found on the Clova mountains by Mr. J. Horsfall. Branched and depauperate.

6o. ramo-multifida, Barnes. Found at Crook, in 1864 , by Mrs. Hartley. Ramose and crested.

6I. ramo-parviceps, Barnes. Found at Orrest Head, in I874, by Mr. T. Airey. Thin texture, ramose, and crested.

62. retusa, Clapham. Found at Ilkley, in I863, by the late Mr. Clapham. Pinnæ curving. $7 \times 1 \frac{1}{4}$ inches.

63. revolvens, Barnes. Found in Sivindale, in 1865 , by the late Mr. J. M. Barnes. Pinnæ recurved.

64. rigida, Lowe (serratum-rigidum, Stansfield).

65. rotundata, Lowe. Found by Mr. Clift in North Wales. Pinnæ short and rotund. Length, 8 inches.

66. semilacera, Barnes. Found at Windermere, by Mr. T. Airey. Alnost bipinnate.

67. serra, Moore. Found in South Wales, in 1867 , by the late Mr. Jacob Jones. $17 \times 2$ inches. A bold incised variety.

68. serrata, Jones. Found in North Wales, in 1865 , by the late Mr. J. Clift. $7 \times 2$ inches. A good serrated form.

69. serrulata, Barnes. Found in Wastdale, in 1876 , by Mr. W. Crouch. Prettily serrulated. 70. stricta, Frances. Common. Length, 9 inches.

7 I. stricto-concinna, Barnes. Found at Crook, in 1865 , by the late Mr. J. M. Barnes.

72. stricto-projecta, Bames. Found at Grasmere, in $\mathbf{1 8 6 5}$, by Mr. W. Crouch. Irregular.

73. stricto-ramosa, Barnes. Found in Wastdale, in 1876 , by Mr. W. Crouch. Ramose. 
74. supeibella, Barnes. Found near Kendal, by Mr. G. Whitwell.

75. subplumosa, Phillits. A leafy form.

76. subserrata, Moore. Found at Burneside, in 1876 , by Mr. G. Whitwell. Pretty, crenate.

77. tridactyla, Moore. Found on Loughrigg, in I864, by Mr. IV. Crouch; and near Portsmouth by Mr. S. Nowell. Robust; crest three fingered.

78. trinervia, Moore. Found in Kent, in IS5I, by Mr. G. B. IVollaston, and on Sugar-loaf Nountains. Wicklow, in I 854 , by Dr. Kinahan. A brachiate form, branching at the base of the rachis. $13 \times \mathrm{I}_{\frac{3}{4}}$ inches. Mr. WV. H. Phillips found many similar plants in County Down and Wicklow, in I878. Mr. T. Airey has observed it at Langdale.

79. trineria-coronans, Moore. Found at Langdale, in Westmoreland, in $\mathrm{I} 872$, by the late Mr. J. M. Barnes. A beautiful compact varicty with a large flat capitate crown, and the ends of the brachiate portions crested. Fertile, II $\times$ I inches; sterile, $5 \times I$ inches.

8o. tripinnata, Lorve (scrratum, Airey, No. I, Irollaston). Tripinnatifid to tripinnate, pinnæ cut down to midrib, pinnule half an inch long and incised.

8 r. variabile, Bames. Found at Crook, in 1866 , by Mr. T. Hartley. Irregular and variable.

82. Wilsona, Lorve (crispum Wilsonx, Irollaston). Found on Blawith Moor, in I869, by Mrs. IVilson. Crispy.

*83. crispata, Mapplebeck; *84. Mapplebeckii; and 8j. Fosteri, I have not seen.

\section{Tribe 8. ASPLENIEAE.}

\section{THE GREEN SPLEENIVORT.}

\section{ASPLENIUM VIRIDE.-Hudson.}

LOCAL, but not common, yet found in many districts growing in moist crevices in rocky mountains. Resembling Asplenium trichomanes the nearest, but distinguished by its green stem and pale green fronds. Evergreen, linear, pinnate, and raries in length from 2 to ro inches.

It has been found at Danny, Southgate, Maidstone, Miclileliam, Ham Bridge, Dove Dale, Buxton, Cavedale, Castleton, Beacon Hill, Carr-edge, Staley, Settle Craven, Ingleborough, Gordale, Aisla-Beck, Richmond, Widdal Fell, Wenslejdale, Ogden Clough, Reeth Moor, Swaledale, near Leeds, Falcon Clims, Wcardale, Patterdale, Kendal Fell, Hutton Roof, Farleton, Arnside, Casterton Fell, Mazebeck Scar, Ambleside, IBorrowdale, Carrick licll, Brandy Ghyll, Ashness Ghyll, Barrow Force, Gillstand, Whitbarow, in Brecknockshire, Glamorganshire, Carnaron, and Mlerioneth. In Scotland, in eleven counties, and in Arran, Mull and Shetland. In Ireland near Lough Eske, lien Bulgen, Bandom, and Killarney. Abroad it is in Fance, Germany, Switzerland, belgium, Norway, Siveden, Finland, Lapland, Russia, Spain, Italy, Greece, Siberiat, 
Bohemia, Dalmatia, Croatia, India, Peru, Columbia, and Rocky Mountains.

\section{VARIETIES.}

I. acutifolium, Gibson. Pinnæe lanceolate and acute.

2. bipinnatum, Clozves. Found, in 1853 , on Whitbarrow, by $\mathrm{Mr}$. $\mathrm{J}$. Huddart. A handsome variety (a copy of $A$. trichomanes, var incisum).

3. Claphami, Lozve (crenatum, Clapham). Found on Pennigent by the late $\mathrm{Mr}$. Clapham. A handsome fern with variable muchincised segments. Tip of frond ramose.

4. crenatum, Wollaston. Found, in I863, on the Breadalbane Mountains, by Mr. A. Stansfield. Pinnac cuneate. Length 3 inches.

5. deltoideum, Clapham. Deltoid, basal pinṇæe very large, rapidly smaller, being minute at the apex.

6. imbricatum, Clapham. Found at Settle by the late $\mathrm{Mr}$ Clapham. Dwarf and imbricate.

7. incisum, Moore. Found in several localities. Pinnze trapeziform and profoundly incised. Length 9 inches.

8. multifidum, Wollaston. Not uncommon. I saw many plants in 1863 on the Falcon Clints, in Teesdale. Apex bifid or nultifid.

9. ramosum, Stansfield. Upper part of frond two or three times branched.

Io. Smithiesii, Lorve.

II. stipatum, Stansfield. Found, in 1863 , on the Breadalbane Mountains, by Mr. A. Stansfield. Pinnæe triangular and conspicuously stipate.

12. varians, Moore. Found on Kendal Fell, by Mr. Barnes. A singular variety; both fronds and pinnæe variable, some depauperate, others beyond the ordinary size. Length 2 to 5 inches.

The present fern, Asplenium Ceterach, and in fact all species that flourish on rocks and walls, require to be grown in exposed situations, using a large amount of stone with the soil. The plan adopted by myself is to grow them in pots, giving the protection of a cool greenloouse in winter, and in April plunging them amongst stones and sand in a long narrow shallow box, fastened on the north side of a wall five feet from the ground, and only watering in very dry weather.

\section{THE MAIDENHAIR SPLEENIVORT.}

\section{ASPLENIUM TRICHOMANES.-Linnculs.}

A COMnION species throughout the United Kingdom, growing on rocks and walls, and occasionally in hedgerow banks. It attains a large size in the West of Ireland, sometimes the fronds being more than a foot long. Found at every height up to 2,000 feet above the sea. On Ben Lawers the plants are very small. In the Eastern Counties it is not common. A native of the Atlantic Isles, Cape of Good Hope, Kaffraria, the Callcasus, Persia, India, Siberia, Europe (throughout), Australasia, North and South America, Peru, 


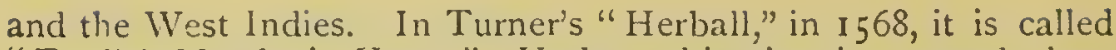
"En ilish Mayden's Heare." Under cultivation it succeeds best in sincly loam with broken stones and a little decayed leafmould.

Stem dark chestnut brown; fronds linear, pinnate, and decp green. A pretty dwarf species.

Some walls in Monmouthshire are literally covered with this fern.

\section{VARIETIES.}

1. acrocladon, Lowe. Found in Owsnip Gill, Swaledale, in I 866 , by Mr. R. C. Brown, of Nottingham. Pinnæ very remote, only seven or eight pairs to within an inch of the tip of the frond, and there branching and rebranching so as to form a capitate head 2 inches bivad. Pinna not crested. Length, 6 inches.

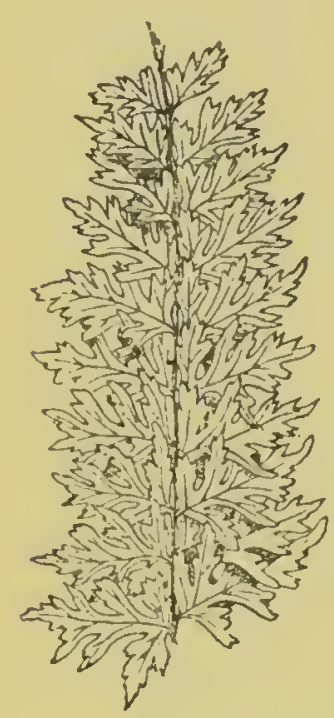

Fig. 10.

Asplenium trichomanes, var. Claphani (incised).

2. Claphami, Lozve (incisum, Moore). Discovered at Smeerset, near Settle, by Mr. A. Clapham and Mr. J. Tathem. The most beautiful variety yet found. An incisum, but unlike the incisum of Moore. Pinne sometimes three-quarters of an inch in length, and as much across the base. The basal lobes cut nearly to the costa; it is serrate as well as lobate. The upper lobes are ahmost as much cut. A sterile very plumose form. Length, 7 inches.

3. confluens, Mloore (Mr. Stabler's confluent hybrid not included). Found many years ago near Whitby, by the late Mr. W. IVilison; and in 1875, in the South of Ireland, by Mr. P. Niell Fraser, of Edinburgh. Pinnæ confluent in the upper half of the frond. Length, 4 inches.

4. congestum, O'killy. Found in County Clare by Mr. O'Kelly. An interesting congested bushy form, $4 \times 0.3$ inches.

5. cornutum, Lowe (cornuto-ramosum, Lowe). Found near the Clitton Suspension Bridge by Mr. Edwards. Rachis flexuose, branching in the middle of the frond, where it is horned. Pinna lix, some absunt. Lengrth 6 inches.

6. corymbiferum, Lowe. Found in Owsnip Gill, by Mr. K. C. Brow.1, and Crossthwaite, by $M$ r. J. M. Barnes. Normal, except at the ap. $x$, where it branches into a wide capitate, foliose heacl. Segments confluent.

$\%$ cristatum, Moore. Found in Lancashire, Cumberland, Viestmorland, Devonshire, and near Ballyvaughan. A handsome, not uncommon fern. The pinnules are from elongate to triangular, and are cut almost to the bisc. In some forms the pinnie are depauprerate. Length, 6 inches.

S. dendruideum, W'ollaston. Found, in $1 \$ 72$, in Westmorcland, 
by Mr. G. B. Wollaston Pinnules small. Length, 3 inches, and almost as much across the many-branched head.

9. depauperatum, Wollaston. Found in I853, at Black Head, County Clare, by Dr. Allchin; and in I 855, at Rydal, by Mr. G. R. Wollaston ; also at Windermere, Arnside, and Bardsea. Intermediate forms have also been found, and Mr. Clapham raised one of these from spores, which he called intermptum, and another, having the apex branched, ramo-depauperatum. The pinnules small, depauperate, and some wanting.

Io. Harovii, Moore. Found by Mr. G. 13. Wollaston, and also at Portskewett, in Monmouthshire, by the late Colonel A. M. Jones, and recently by myself. A dwarf slender form, with numerous deeply cut pinnæ. Length, 5 inches. Trogyense is, however, a more marked form.

II. hybridum, Lozve (confluens, Moore). Found, in I 870, on Levens Park wall, in Cumberland, by Mr. Stabler, of Levens. It is strikingly different from all other forms of comfluens. An undoubted hybrid, probably between $\mathrm{A}$. trichomanes and $\mathrm{A}$. marinum (the counterpart of microdon, a hybrid of $A$. marimum). Although copiously soriferous, there are no germinating spores, which is the case with the other hybrids. It is not impossible that at some time or other a few spores may germinate, but with these hybrids this is extremely rare.

When last seen, the plant was in the possession of $\mathrm{Mr}$. Barnes, of Milnthorp; it was then a grand specimen. The stem is much thicker than is the case with the ordinary form of Asplenium trichomanes. From near the base the pinna are imbricate, and towards the apex confluent. Length Io to I I inches, width exceeding an inch.

12. imbricatum, Clapham. Found,

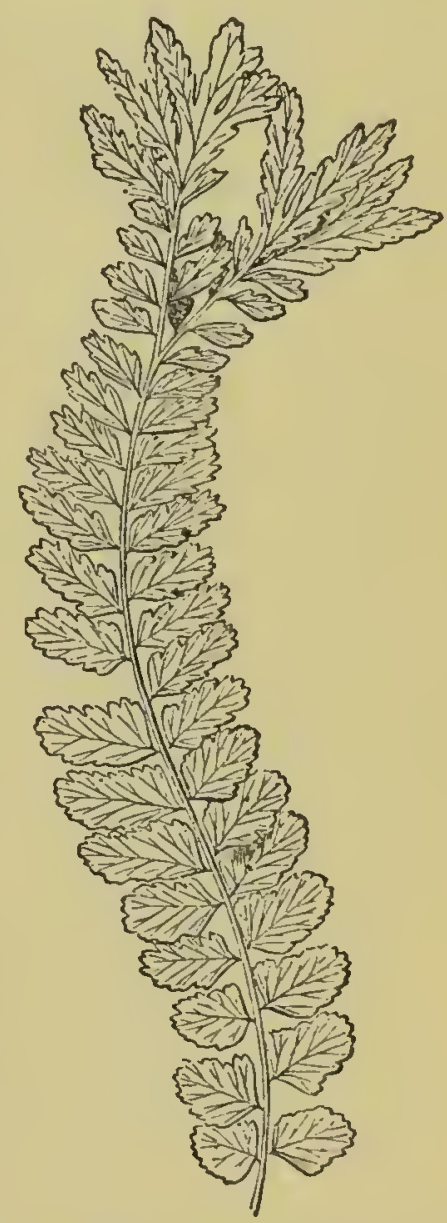

FIG. 11.-Asplenium tric'iomanes, vatr. Lristatuin (showing cresting).

in I863, at Knaresborough, by Mr. A. Clapham. Pinnæe scarcely stalked, large, and overlapping, the base square, and the margins prettily dentate. Length, 3 inches.

I3. incisum, Moore (excluding Mr. Clapham's Settle plant). Found in Devon by the Rev. W. S. Hore; near Burnley, by Mr. S. Gibson ; in Borrowdale, by Miss Wright; and near Pyle, in 
Glamorganshire, by Mr. E. T. Higgins. All are sterile except the Glamorganshire plant. Exceedingly beautiful and plumose. Pinnæe somewhat triangular, deeply incised, and the tips pointed. Length, 4 to 6 inches.

14. katastacton, Lowe. Raised from spores at Highfield House. Pinnæ imbricate and indistinctly crenate and rotundate. Length 3 inches.

15. laciniatum, Lorve (incisum-laciniatum, Moore). Found, in 1863 , in County Clare, by $\mathrm{Mr}$. R. Stansfield. A distinct laciniate, incisum form.

16. majus, Padley. Found near Plymouth, by the Rev. C. Padley ; in County Clare, by Mr. Foot; near Ballyvaughan, by Mr. P. 13. O'Kelly; and at Dennil Hill, near Chepstow, by Major Cowburn. Normal, except its gigantic proportions. Length from 12 to 18 inches, and 3 inch wide.

17. Moulei, Moore. Found in Devon by Mr. Moule. Pinna narrow, margin wavy. A seedling raised from this "incisura" (Lowe) has long narrow pinne deeply and equally incised on both margins.

18. multifidum, Moore. Found at St. Mary's Isle, Kirkcudbright, by Mr. Dick; at Windermere, by Mr. Clowes; Ulverston, Mlrs. Hodgson; Keswick, Miss Wright ; at Capel Curig, North Wales, by Mr. S. Clift; and in Swaledale, by Mr. Brown. The froncls are scveral times ramosely forked considerably below the apex, and the tips are multifidly crisped. Pinnre small.

19. O'Kellyi, Lowe. Found in the Burren district, County Clare, by Mr. O'Kelly. An incised form of triangulare with longer and more lax fronds, and smaller segments than incisum-triangulare. An interesting variety.

20. Pateyi, Lovve (ramo-cristatum, Wollaston). Found, in 1873 , in Cardigan, by Mr. Patey. Another branched cristatum with a less crested head than the ramo-cristatum of Moore. It is more ramose but less crested than Mr. Moore's plant, having a compact head $1 \frac{1}{2}$ inches in diameter. Length, 3 inches.

21. polydactylum, Lotere (cristatum, $O^{\prime} \mathrm{K}^{\prime} \mathrm{ell} \mathrm{y}^{\prime}$ ). Found in County Clare by Mr. O'Kelly. I $\times \mathrm{O}_{\frac{1}{2}}$ inches. Nuch larger than cristatum.

22. ramo-cristatum, Moore. Found, in 1861 , in Cornwall, by Mr. W. H. Sargeant. Normal below, branching near the apex into six or seven crested branches that are 3 inches across. Length 4 inches.

23. ramosum, Wollaston. Found in $186+$, in Soutli Devon, by the late Rev. C. Padley; Ilfracombe and 'Tiverton, by Mls. Chanter ; Windermere, by Mr. Clowes; Keswick, by Miss Wright ; Arnside, by Mr. Crossfield; Underbarrow, by Mlr. 'T. Hartley"; Owsnip Gill, Swaledale, by Mr. K. C. Hrown; Conway, by Mr. A. Stansficld ; and in Comnty Clare, by 1)r. Kinalann. Stem divicling and sub-dividing into four or five wide-spreading branches. P'innie narrow and more or less depauperate. Lengtli 4 to 5 inches.

24. sulacquale, Moore. Found near Monmouth, by Mr. J. D. 
Enys; Knaresborough, by the late Mr. Clapham; Whitbarrow, by $\mathrm{Mr}$. Clowes; Nettlecombe, by the late Mr. Elworthy; and at Tunbridge WVells, by the late Mrs. Delves. Fronds narrow, and broadest at the base. Pinnæe small and crenate.

25. triangulare, Lowe (incisum-triangulare, Moore). Found, in I863, in County Clare by the late Mr. Stansfield. An incisum with triangular pinnæ. Length, 4 inches.

26. Trogyense, Lowe. Found in IVentwood, Monmouthshire, by myself, in I882. This differs from Velum in not having the prominent basal lobe, and in being approximate instead of imbricate. Fronds very brittle, colour a blue green. Length, 5 inches; width, nearly $\frac{1}{2}$ inch.

27. velum, Lowe. Found in Wentwood, by myself, in 1890 . Frond very symmetrical, and of a blue green colour. Copiously soriferous. A very handsome variety. The pinnæ much incised, and the lower basal lobe of each pinna standing out almost at right angles to the remainder of the pinna like a curtain, the folds resembling stairs. Length 4 inches, and nearly 3 inch wide at the base of the frond.

Other varieties, viz., bifurcum, rotundato-multifidum, Blechnoides, lineare, and rotundatum, have been found in the Lake district, but I have not seen them.

\section{THE FORKED SPLEENIVORT.}

\section{ASPLENIUII SEPTENTRIONALE.-Hoffinann.}

A Diminutive fern with forked fronds and linear segments, unlike all others. It is evergreen, 2 or 3 inches in length, and of a deep green colour, the stipes being longer than the fronds. It grows in fissures of rocks and between the stones of loose walls. Found in the Lake district near Ambleside, on Helvellyn, Honiston Crags, Red Screes, Crummock Water, Langdale, Scafell, Patterdale, Keswick, Wastwater, Borrowdale, in the vale of Newlands; at Kyloe Crags, Northumberland; Ingleborough, Yorkshire; and at Culborne, near Oare Church, and Exmoor, Somersetshire. In IVales, near Llanrwst, Pass of Llanberris, Bettwys-y-Coed, Capel Curig, Pont-y-Pair, Llewellyn, and Llyn-y-Cwn. In Scotland: in Roxburghshire, Edinburghshire, Perthshire, and Aberdeenshire. It used to be much more plentiful on Arthur's Seat, Edinburgh, and it is not common on Stenton Rock, near Dunkeld, where a few years ago I only saw a dozen plants (E. J. L.). It is not found in Ireland.

Abroad it is a native of Scandinavia, Russia, portion of mature Sw $i$ tzerland, France, Germany, Spain, Portugal, Italy, Belgium, Hungary, New Mexico, and Northern India.

No varieties are known. 
THE SEA SPLEENWORT.

\section{ASPLENIUM MARINUM.-Linnaus.}

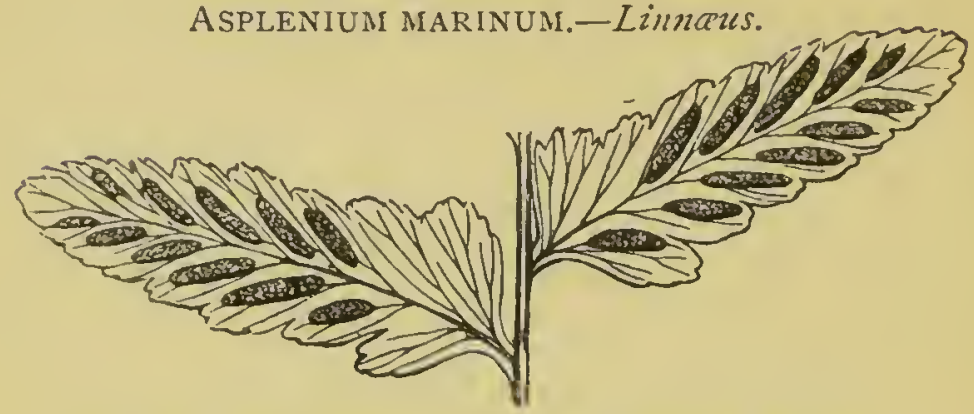

FIG. 13.-Pinnæ, showing fiuctiflation of Asplenium marinum.

IN clefts and caves of rocks, mostly on the sea coast. An evergreen, with shining deep green fronds varying from 6 inches to 3 feet in length. Pinnate, the pinnxe being usually an inch long. The stipes shorter than the frond, and channelled in front; sori linear and oblique.

Like the "Maiden-hair" it is soon killed by frost, and therefore requires the protection of a greenhouse in winter, although in its protected sea-caves it grows in districts of severe frost.

Common in Cornwall, Devon, Dorset, Somerset, Sussex, Yorkshire (the habitat north of Scarborough destroyed by the falling of the face of the cliffs), Durham, Cumberland, Northumberland, Westmoreland, Isle of Wight, Isle of Portland, Isle of Man, Holy Island. At the mouths of the Mersey and Dee; Gloucestershire, Warrington, and Newton (rare). In Wales: Merionethshire, Carnarvonshire, and Island of Anglesea. On the east and north coast of Scotland, and in the Western Isles in Orkney, and on Ailsa Craig. In Ireland: Down, Galway, Clare, Dublin, Kerry, Cork, Isle of Rathlin, Arran Isles, Guernsey, Jersey, and abundant along the coast of Connaught and Munster.

It is also found in France, Spain, Portugal, Italy, Corsica, Ionian Isles, Barbary, Tangiers, Madeira, Azores, Canary, St. Helena, New Holland, Rio Grande, New Brunswick, Bermuda, and in North America. In 1860 I found it at the summit of the Vilea Escusa, between Reinosa and Alar, during the time of the Himalaya Eclipse Expedition to Spain, and also on the coast near Santander.

\section{VARIETIES.}

I. acutum, Moore. Found in Jersey, Guernsey, P'lymouth, and Dartmouth. Pimne lax and narrowing to a sharp-pointed apex. Length 2 feet.

*2. Auchmithianum, Lorve. A singular variety, with very prominent ribs on the pinna. The apices of the pinne rounderl and somewhat crenate. Length, 6 to 8 inches. Found by myself in sea-caves at Auchmithy (between Arbroath and Aberdeen. To reach these caves, it is requisite to have a long ladder, and they can 
only be searched at low water on this wild rocky coast. The ferns were very abundant and extended some distance into the caves even where there was but feeble light. Some of the caves are full of water even at low tide, having a passage to the sea, and in these were numbers of seals that darted out on being approached.

3. bicrenatum, Stansfield. One of Messis. Stansfield's sports. The two basal pair of pinne distant, the remaining touching each other, margin bicrenated. Length, 6 inches.

4. brachiatum, Moore. Found in Cornwall by Mr. J. Herbert in 1874 . Pinna narrow, with blunt tips, the two lowest brachiate (i.e. distinct branches) and twice as long as those immediately above. Length, I foot.

*5. capitatum, Clapham. Found in I86I near Scarborough. Stem naled for the basal 5 inches, then the leafy portion divided into a capitate head 5 inches wide, the pinnules overlapping. Length ro inches. I have raised many capitate seedlings from this variety.

6. caudatum, Clapham. Raised from spores by the late Mr. A. Clapham, of Ramsdale Bank, Scarborough. A very distinct fern, with narrow pinna, the frond terminating in a long caudate (or tail-like) apex. Length, 6 to 8 inches.

*7. decorum, Lowe. Found by Sir W. Jackson Hooker, and also by $\mathrm{Mr}$. O'Kelly in the Burren district, County Clare. $8 \times 1$ inches. Narrow and smooth.

8. Hookeri, Lowe. Found in abundance in the Burren district, County Clare. I received it from the late Sir William Hooker many years ago, and again recently from Mr. P. B. O'Kelly, Glenarra House, Ballyvaughan. More than 2 feet in length, with short blunt pinnæ.

*9. imbricatum, Lorve. Found in I865, in North Wales, by the late Mr. Clift, of Birmingham, who sent me the original plant, which is still alive. A very distinct variety. The pinnae overlap each other as if tiled. Apex of the frond caudate. Length, 8 inches. A variety named by $\mathrm{Mr}$. Clapham, imbricatum Lowei, is rather larger and more imbricated. $\dagger$

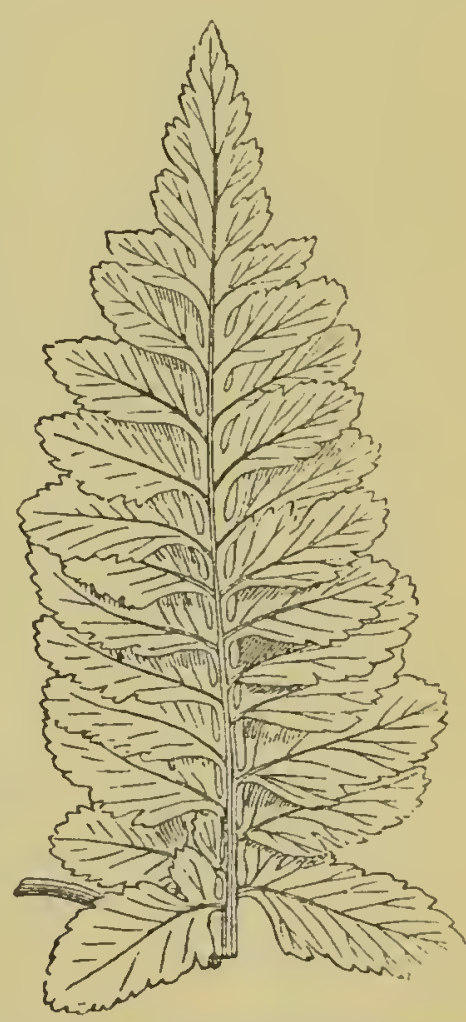

Fig. 14.-Frond of Asplenic m marinum, var. imbricatum.

+ Another form raised by nyself. Imbricatum superbum is even more characteristic. 
Io. incisum, Moore. Found at Great Orme's Head by Mr. A. Stowe, and near Llangollen by the Rev. T. Rooper. An elegant variety, having the pinne and apex of the frond truncate (or bluntended). The lobes deeply cut along the anterior margin. Length 6 to 9 inches. Pinnae only half an inch long.

I I. interruptum, Moore. History doubtful. Remarkable for the varied length of the pinnæ, some projecting far beyond the others causing the outline to be irregular.

12. laxum, Loree. Found in the Burren district, County Clare, by Mr. F. J. Foot, of the Geological Survey of Ireland. It is not unlike the Asplenium latum (a South European form of $A$. marinum). Very lax, especially on the lower portion of the frond. Length 2 to 3 feet.

13. multifurcatum, Clapham. Raised from spores in 1860 by Mr. Clapham. Lower pinna very short and depauperate. Frond terminating in a rounded capitate head.

14. multipinnatum, Appleby. Stated to have been found in the Azores. A most beautiful ramose variety growing more or less horizontally. Fronds equal in width throughout, terminating in a branching apex. Pinnæ broad and the segments deeply cut.

* I5 optandum, Lowe. Raised by myself. An interesting variety having the lower lobe of the pinnules overlapping. Length 5 inches (identical with admirabile, Lowe).

I6. parallelum, Moore. A distinct form found in Guernsey by M. Boistel. Fronds 3 feet in length. Pinnre 2 to $2 \frac{1}{2}$ inches long and less than $\frac{3}{8}$ inch wide, and nearly parallel sided.

17. plumosum, Wollaston. Found in Guernsey by the late Mr. C. Jackson. A magnificent plumose variety in the style of Thompsonx, but every part of the frond is double the size of that variety. The ends of the pinna are caudate, and the pinnules divided nearly to the base. Length, from I to 2 feet.

18. Prica, Lowe (plumosum Price, Jones. Found near Ilfracombe by Miss Price. A beautiful foliose form, not so much divided as plumosum. Frond widest at the base, as also the pinnæ. Basal lobes large and deeply cut. $7 \times 4$ inches.

*19. ramo-capitatum, Lowe. Raised by myself. Branched and capitate.

20. ramo-trapeziforme, Clapham. Found in is57 at Burniston, near Scarborough, by Mr. A. Clapham. Dwarf. Pinne trapeziform, and variable in size and shape. l'inna branching and the tips dilate. A somewhat similar form was raised by myself.

$2 \mathrm{I}$. ramosum, Vollaston. Found in $\mathrm{I} \$ 50$, in Dorsetshire, by Mr. G. B. Wollaston. Distinet dwarf variety, with short wide pinna, having a broadly crenate margin. Twin-fronded, either branching in the stipes or in the rachis.

22. subpinnatum, Moore. Found in Petit bot Bay, Guemsey, by Mrs. Dobree. It has also been found in Comwall. I'rofoundly pinnatifid with deeply divided lobes. Length, 7 inches, breadth, $2 \frac{1}{2}$ inches. 
23. subserratum, Stansfield. Pinnæ lax, long and narrow, bicrenate, and the crenatures minutely serrate.

*24. Thompsonæ, Lowe. Found in North Devon by Mrs. Thompson. A plumose variety and only second to plumosum as a beautiful variety of this species. Very feather-like in appearance. Fronds narrower at the base. Pinnæ long, narrow, and conspicuously auricled. The superior margin is crenato-serrate yet not deeply divided, whilst the inferior margin is very deeply cut into narrow segments. This applies to the upper half of the frond. Length, 12 inches.

25. trapeziforme, Clapham. Found in Cloughton Bay, near Scarborough, by the late $\mathrm{Mr}$. Clapham (the locality now destroyed by the falling of the cliffs). A similar form has been found in Cornwall, Devon, and in County Down. Dwarf, trapeziform, with brief blunt pinna. Texture leathery.

26. variabile, Monkman. Raised from spores by the late Mr. Clapham. The fronds sometimes branch and rebranch several times, no two being alike. It is of erect habit and trapeziform. Length, 8 inches, with a breadth across the ramose head sometimes as much as 4 inches.

27. variegatum, Lowe. Found by myself in 1876 in a sea-cave at Auchmithy, where it is (or was) abundant. A form of Auchmithianum, with fronds regularly variegated green and white.

28. Wollastoni, Lowe (acutum, Wollaston). Found in Cornwall by Mr. J. Herbert. An acutum, but not of Moore, hence the change of name. Pinnules very narrow and acute. Apex caudate.

\section{THE ALTERNATE-LEAVED SPLEENWORT.}

\section{Asplenium Germanicum.-Weis.}

A NOTHER very divarf rare species, growing in fissures of rocks up to an altitude of 1,000 feet. It is usually found growing with Asplenium septentrionale, and may be a hybrid between that and Asplenium ruta-muraria. At all events, I have been unable to raise it from spores.

The fronds are pale green, from 3 to 4 inches long, with a slender stipes of half the length of the frond. They are pinnate to sub-bipinnate, and have a halfway character between A. rutamuraria and A. septentrionale. Sori linear, elongate, and central.

It has been found on Helvellyn, Borrowdale, Scafell, Kyloe Rocks (Northumberland), and near Culborne (Somerset). In Wales, near Llanrwst, Llanberris, and Capel Curig. Some years ago I saw it growing and of large size in Cefn Cave. In Scotland it is recorded at Perth, Dunkeld (Stenton Rocks, where I failed to find it), Dunfermline, Kelso, and near Hassendeen. In 1857

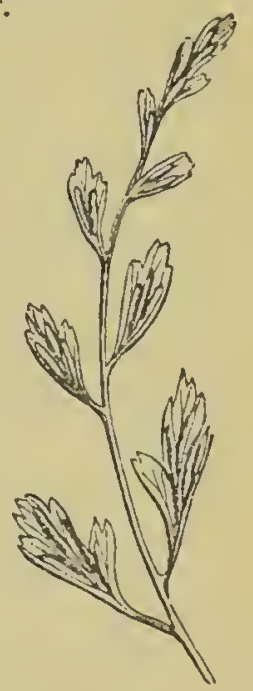

FIG. 15.

Frond of Asplenium Germanicum. 
Mr. P. Neill Fraser gathered it near Edinburgh. Mr. D. Hutchison says it is also plentiful near Airlie Castle. Not an Irish species.

Found in the Gulf of Finland, in Norway, Sweden, Belgium, Sivitzerland, France, Germany, Hungary, Spain, Italy, Croatia, Dalmatia, Bukowina, and on the Tyrol and Carpathian mountains.

One variety has been described,-acutidentatum, Moore, which was raised from spores by Mr. Sim, of Foot's Cray. It differs in having the teeth of the lobes acute instead of obtuse.

\section{THE WALL RUE.}

\section{ASPLENIUM RUTA-MURARIA.-Linnaus.}

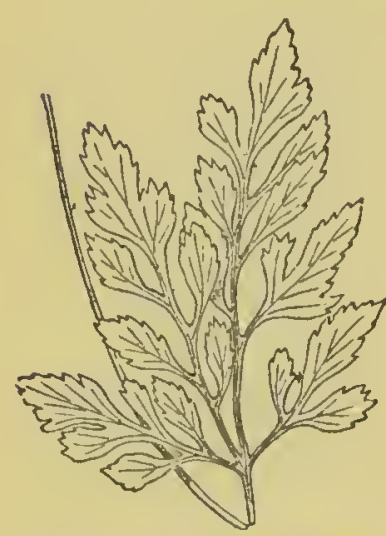

FIf. 16.-Asplenium Rutamuraria, var, ramosum.

ONE of our most abundant ferns, though less common on the eastern side of England. Found on old walls, rocks, churches, bridges, and ruins; in the drier districts occupying a northern aspect.

Forming tufts of fronds from $I$ to 6 inches in length, usually about 2 inches. It can only be confused with the Asplenium Germanicum, and even this may possibly be a hybrid between the Wall Rue and the Forked Spleenwort. Although so common, it is difficult to cultivate. A very large amount of broken limestone in proportion to the soil, and a dry airy situation is essential. Widely spread in all temperate climates.

\section{VARIETIES.}

I. attenuatum, Lowe. Large growing ( 5 or 6 inches), branched and attenuated. Found at Athlone by Mr. F. J. Foot, of the I/ ish Survey.

2. cristatum, Wollaston. Tasseled in various ways, and the rachis often divided. Found near Ruthin Castle by Mr. J. Diniels; Guildford, by Dr. Allchin ; and near Tunbridge Wells, by Mr. G. B. Wollaston.

3. cuneatum, Moore. Mostly merely pinnate with long, narrow, cuneate-based pinnules. Found at Stenton Rock, near Dunkeld; also near Bitton, by the late Rev. T. Ellacombe, of Bitton Rectory; near Bristol ; and at Sizergh, in the Lake district, by Mr. J. Crossfield.

4. dissectum, Wollaston. Elongated and deeply incised pinnules. Found in Devonshire by Mr. G. I3. Wollaston; and in County Louth by the late Dr. Kinahan.

5. elatum, Lung. Tall ( $4 \frac{1}{2}$ inches), slender, often tripinnate, pinnules very small and narrowly cuneate. Found at Emis by Dr. Allchin; Michelstown Castle, by Mr. P. F. Keir; near Athenny, by Mr. R. Barrington ; Keswick, by Miss IVright ; in Doredale, by Mr. Wilson ; and in County Clare, by Mr. O'Kelly. 
6. pinnatum, Moore. Only once pinnate. Found near Killarney by Dr. Allchin.

7. proliferum, Wollaston. In this variety young plants are formed on the axils of the pinnules. Found near Guildford by Dr. Allchin.

8. ramo-depauperatum, Clapham. Branched and depauperate. Found at Settle by Mr. Clapham.

9. ramosum, Moore. Branching in the upper part of the frond. Length, $2 \frac{1}{2}$ inches. Found at Arnside, by Mr. J. Crossfield; at Settle, by Mr. Clapham; in County Clare, by Mr. O'Kelly.

Io. sectum, Moore. Ends of pinnules incised, producing a forked appearance. Found at Arnside by Mr. J. Crossfield.

II. spathulatum, Moore. Large and spathulate. Found at Town Malling, by Dr. Allchin; Marwood, by the Rev. F. Mules; Settle, by Mr. Clapham; Dunkeld, by the Rev. R. Taylor ; and at Fife, by Mr. C. Howie.

12. Striguilense, Lowe. Found at Portskewett by myself in I Sgo. A divarf robust form, with deep green fronds only I inch in length.

13. trifidum, Moore. Dwarf, deeply divided into three cuneate segments. Found at Malgivyn Castle by Mr. W. Hutchinson.

14. trifoliatum, Lowe. Dwarf. Pinnæ trifoliate. Found near Barnstaple by the Rev. F. Mules.

I 5. unilaterale, Moore. An irregular variety, with the pinnæe all on one side of the rachis. Found near Killarney, by Dr. Allchin; at Black Head, by Mr. R. Barrington; at Chaigeley, near Clitheroe, by myself; at Troutbeck, by Miss Wright ; and Kendal Fell, by Mr. J. M. Barnes.

16. variabile, Moore. Pinnæ and pinnules exceedingly dissimilar, pinnules very small. Found at Settle by the late Mr. Clapham.

\section{THE BLACK MAIDEN-HAIR SPLEENWORT.}

\section{ASPLENIUM ADIANTUM.NIGRUM.-Linnanı.}

THE present species cannot well be confounded with any other. It approaches nearest to $\mathrm{A}$. lanceolatum; but the fronds are triangular instead of lanceolate, and in A. Adiantum-nigrum the sori are not submarginal. The stem is as long as the leafy portion of the frond, whilst in A. lanceolatum it is only a third the length of the frond.

Fronds ovate or deltoid, bi- or tri-pinnate. Length, from 3 to 20 inches, and varying in width in the leafy portion from $1 \frac{1}{2}$ inches to 7 inches. Shining dark green. An evergreen. Rocks, walls, and sandy banks are its natural habitats.

A common fern (though not abundant in Ireland). It occurs all over Europe.

\section{VARIETIES.}

I. acutum, Pollini. This variety has been found in a number of places in Ireland and on the Continent. Whilst in Northern Spain, in 1860 , I found this fern in the greatest profusion near Santander, Las Caldas, between Reinosa and Allar, and in the Congosto Pass, 
in the latter locality, growing in the shade of huge plants of Woodwardia radicans that were on the sides of the railway. It is a linear-acute, caudate form.

2. alcicorne, Lore. Raised by myself. $6 \times 2$ inches, the upper part branching like stags' horns.

3. angustatum, Lozve. Found in the Burren, County Clare, by Mr: P. B. O'Kelly. It is an acutum-form, but the fronds are narrower and longer than in acutum.

4. caudifolium, Moore. Found by Mr. Druery on a stone wall on Dartmoor. A singular form, the frond and pinnæ terminating in long tail-like ends. The lobes are blunt and yellowish.

*5. Cowperi, Lowe (grandiceps, Wollaston). Found in I865 at Ilfracombe by Mr. Richard A. Thompson. It is a grandiceps, differing from the Irish form in having more pinna below the capitate head, in the segments being narrower, and in not being confluent in the basal pinna. The branching head is larger ( $4 \frac{1}{2}$ inches wide), and its base not conspicuously cuneate as in grandiceps. Length, 8 inches.

6. cristatum. I have not seen this.

7. flabellatum, Lowe. Kaised by Messis. Stansfield. Distinctly

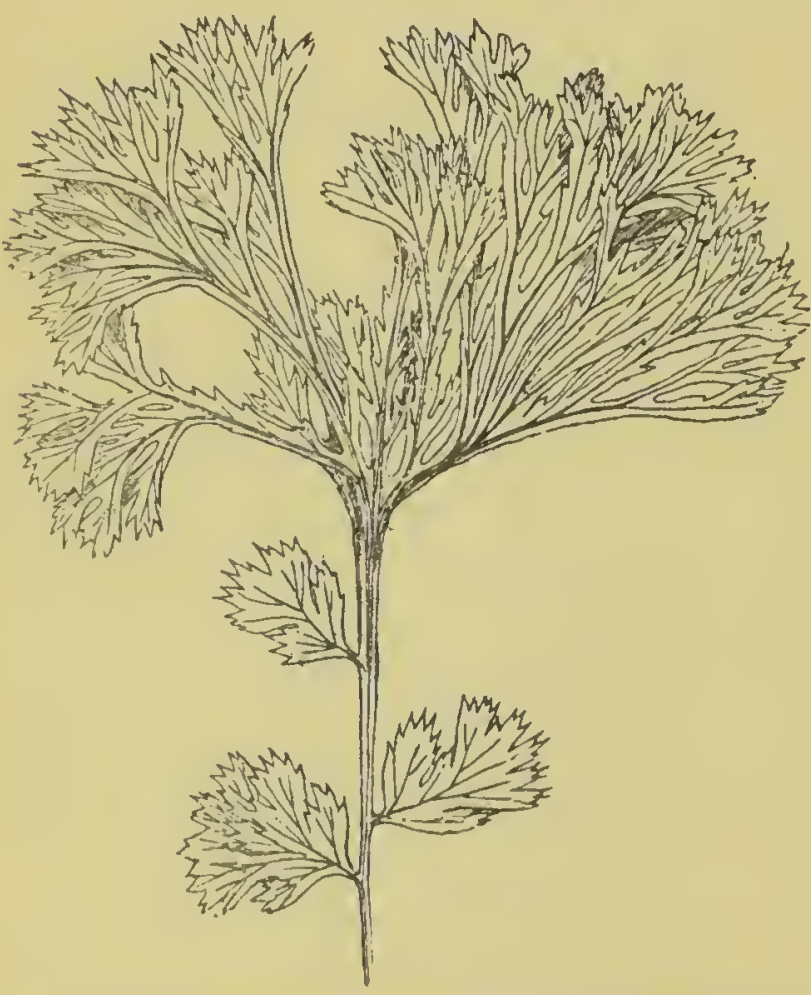

IFt, 17. $-\Lambda$ splonium $\Lambda$ diantum-niprum, var, grand ceps showing capitate licad). flabellate, and branching near the apex.

*8. grandi ceps, Lowe. Found in 1865 , in Waterford, by the Rev. Travers Snith; $4 \frac{1}{2} \times 2$ inches. liead, 3 inches wicle. A very handsome variety, having a large compact head which is cuneate at the base. The peculiar fan. shaped pinne and carpitate head cause it to be rery distinct. 'There are only two or three pairs of pinnie below where the stem branches; and below the point 
of branching there is a space without pinnze, which is not the case in centiceps. Mr. Travers Smith sent me fronds in 1865, and from them I raised a large number of seedlings, which, in 1868 , received a First Class Certificate on July 16 th from the Royal Horticultural Society.

9. incisum, Clapham. Found in 1859 , between Whitby and Scarborough. Dwarf. Pinne triangular, and the segments deeply incised.

10. lineare, O'Kelly. Found near Ballyvaughan by Mr. O'Kelly. $12 \times 3$ inches. A very fine form with almost linear segments.

11. microdon, Moore. Found in 1872 near Ashburton, in North Devon, by Miss Bickford and Mr. James Richards. An undoubted hybrid between the present species and A. marinum. It is sterile. Larger in size though not unlike the hybrid (microdon) of Asplenium lanceolatum and A. marinum. Length, 6 to 10 inches, width at the base, 4 inches. $t$

12. obtusatum, Moore. Found in Devon, Kent, Yorkshire, Stirling, Argyle, Guernsey, and in Ireland. The pinnze are short and the pinnules roundish. Length, varying from 2 to 8 inches.

I3. ramosum, Lowe. Found near Plymouth by the late Rev. C. Padley. Branching several times an inch below the apex, otherwise it is like obtusatum. Length, 6 inches.

14. serpentini, Stansficld. An interesting dwart form.

15. variegatum, Wollaston. Found both in Yorkshire and in Guernsey. Normal in all respects except being striped with white.

\section{THE SMOOTH ROCK SPLEENWORT.}

\section{ASPleniUm FONTANum.-Bernhardi.}

A VERY rare, divarf fern, growing on rocks and walls. 'The usual length of frond, four or five inches. It is rather tender, and requires cultivating in a greenhouse, where it grows readily in porous soil, turfy peat with abundance of gritty silver-sand, and a little friable loam. In habit it is erect and tufted, bipinnate and natrow, the frond narrowing from the centre both towards the base and apex. Colour dark green. The mar-

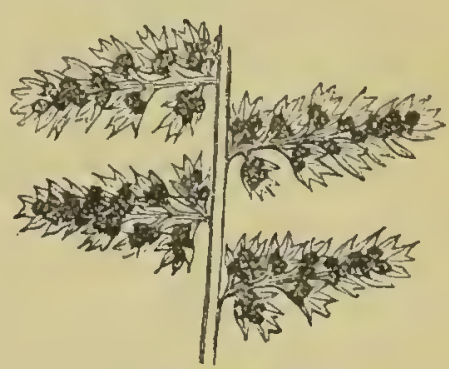

Fig. 18.-Asplenium fontanum.

Portion of mature frond, under side. gins of the pinnules spinosely dentate. Found near Petersfield, Hampshire, by the Rev. W. H. Hawker; in Swanage Cave, Isle of Purbeck, by Dr. Power; near Tooting, by Mr. Gibbs; between Tan-y-Bwlch and Tremadoc (Sir IV. Hooker); and there are several other recorded habitats in Westmoreland, Derbyshire, Yorkshire, Northumberland, Kincardineshire, and Belfast, but these seem to refer to a variety of Cystopteris fragilis. 
There is a form known as Halleri, yet it is doubtful whether this is not the result of cultivation.

It is just possible that Asplenium fontanum is a variety of the North American Asplenium ebeneum. Both Mr. Moore and Mr. Clapham held this view; and this notion is strengthened on examination of the variety refractum.

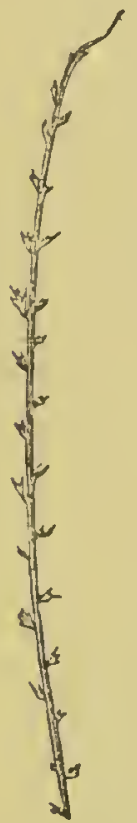

FIG. 19.-Frond of Asplenium fontanum. Var. depauperatum.

A native of France, Germany, Italy, Switzerland, Spain, Belgium, Greece, Hungary, Siberia, and Kashmir.

There are several marked varieties :-

I. depauperatum, Stansficld. Length, 2 inches. A remarkable variety, the leafy portion entirely absent, a brief connected footstalk alone being present, surrounded by spore cases.

2. laciniatum, Stansfield. Frond, 6 inches; width in centre, I inch.

This is a very much incised variety.

3. laxum, Stansfield. Lax, with alternate pinnx. Length, 5 inches.

4. multifidum, Stansfield. Length, 5 inches, the main difference being, that the frond divides and sub-divides into branches from 2 inches below the tip.

5. refractum, Moore. Length, 7 inches; much narrower and more equal in width than $A$. fontamum, and has refracted pinnze. Rachis bulb-bearing. Found in Scotland by Mr. Filden; but his death cast obscurity over this interesting plant.

It was first seen at Peper Harrow Park, Surrey, and was afterwards introduced by Mr. Parker of Hornsey.

\section{THE LANCEOLATE SPLEENIVORT.}

\section{ASPLENIUM LANCEOLATUM.-Hudson.}

A SEASIDE fern, and only locally abundant; not much unlike Asplenium adiantum-nigrum; but the stalks are not as black as in that species, and the frond is more lanceolate in form. Very variable in size, sometimes only four inches, and sometimes as much as I $S$ inches; growing on walls and rocks in sheltered situations. It requires the protection of a greenhouse, and cannot flourish in excessive moisture.

A native of Cornwall, Devon, Somerset, Sussex, Kent, Gloucester, Pembroke, Glamorgan, Merioneth, Carnarvon, Denbigh, and Cork; also of Jersey, Guernscy, Scilly, and Ramsay. Abroad it has been found in Greece, France, Germany, Spain, Portugal, Switzerland, Belgium, Madeira, Azores, Algriers, Tangier, and St. Helena.

There are a dozen varietics. 
I. bifidum, Lowe. Found in Devon. Divided near the apex. Length, 4 inches.

2. caudatum, Lorve. Raised from spores. Less divided, and caudate. Length, 5 inches.

3. Claphami, Moore. Raised by Mr. Clapham. Evidently a hybrid with Asplenium marinum. Fronds narrower than microdon.

4. crispatum, Moore. Found in Guernsey by the late Mr. C. Jackson. Margins crispy.

5. cristatum, Druery. This is mentioned in Mr. C. T. Druery"s interesting work on "Choice British Felns" as being a recent wild find, and, although yet young, heavily and symmetrically crested.

6. excisum, Lowe. Found at Shawbiidge by Mr. G. IV. Edwards. Pinnules variously shaped at the upper part of the frond, and the apex is as if bitten off.

7. incisum, Lowe. Found in Jersey. Robust ; pinnules deeply incised, some depauperate. Length, I2 inches.

8. Kalon, Lorve. Found in 1864 in Devon. Pinnze crowded and overlapping on their basal half. Length, 5 inches.

9. Kitsonx, Lowe. Found in Devon by Miss Kitson. Pinnæ and pinnules lax, more than usually dentate, and their apices blunt. Length, i4 inches.

10. laciniatum, Wollaston. Found in the Channel Islands. Depauperate, the leafy portion often wanting, and the sori showing on the upper sulface.

II. microdon, Moore. A hybrid with Asplenium marinum. Found in $\mathrm{I} 855$, in Guernsey, by Miss Wilkinson, and afterwards by Miss Mansell and Mr. C. Jackson; also near Penzance by Mr. $\mathrm{G}$. Wager. An interesting intermediate form with narrow tapering fronds; confluent at the upper portion. It more nearly resembles Asplenium marinum, but the substance is less leathery, and the colour a paler and less shining green. Sori copious but mmature. Length, 12 inches.

12. obtusum, Clapham. Raised by the late Mr. Clapham. An stuse truncate apex. Length, 9 inches. 


\section{THE LADY FERN.}

\section{ASPLENIUM FILIX-F(EMINA.-Bemhardi.}

\section{(Sub-section Athyrium.)}

THIS common and elegant species is found throughout the United Kingdom, and is generally distributcd through Europe and North America. It is the only species in subsection Athyrium in this country: A deciduous fern, luxuriating in damp, shady places, though found in open situations where there is sufficient moisture. The Lady Fern has a range from the sea-level to 3,000 feet, and at the greater heights assumes the form known as rhaticum or irrigum!

Fronds bi-tripinnate, sori oblong-lunate protected by an indusium. It is most ncarly allicd to the dwarf Asplenium fontanum. The curved sori secms to be the main distinction between Athyrium and Asplenium. Asplenium Filix-fomina varies in the length of its fronds from I to 3 fect. It camnot be confused with any other fern.

\section{VARIETIES.}

There are many varietics of the Lady Fern, some of which are marvellous in structure. It has therefore becn considered desirable to classify these into Divisions, Groups, and Sections. Not only does this scem nccessary with Asplenium Filix-fœmina, but also with Aspidium angulare and Scolopendrium vulgare, as a nieans of shortening many cumbersome names.

\section{Division A.}

\section{CHANGES IN SKELETON.}

\section{Group 1. Branching.}

Section a. RAMOSUM. (Stipes branching.)

I. acrocladon, Noore (ramo-cristatum, Jones). Found in IS60, near Castle Howard, by Mr. Monkman. $12 \times 11$ inches (across the much-branched head). A remarkable form, ncarly ahways sterile. I have a batch of promising seedlings.

*2. apioides, Loreve. Raised by myself. $10 \times 8$ inches. Stipes branching, very parslcy-like.

3. brachiatum, Hodgson. Found in 1866 , in Lancashirc, by Mrs. Hodgson. $12 \times 2 \frac{1}{2}$ inches. Stem branching into 3 or 4 frond-like divisions.

*4. caudiculatum, Mapplebect.

* 5. cladodesteron, Lor'e. Raised by inyself. Length, iz inches. Branched, crested, and heavy-headed.

6. crispum, Moore. lound in Antrim, and at liracmar and Todmorden. Length, 6 to 2 inclics. A mass of densely tiasselled branclies.

7. densum, Loace (acrocladon-densum, Stansfield). liaised by Messrs. I: W. and II. Stansfick, in I气̈\$ (from acrocladon) dense lr onded. 
8. echnomocladon, Lozve (laciniato-acrocladon, Stansfield.) Raised by Messrs. Stansfield. Length, 9 inches, and 6 inches across the head. Stipes and basal half of the branches naked. Laciniate.

9. incongruum, Barnes. Found in 1874, at Langdale, by Mr. J. M. Barnes. A remarkable variety branching in all its parts.

10. magnicapitatum, Stansfield. Raised in 1878 , by Messrs. F. IV. and H. Stansfield. $12 \times 7$ inches. Very distinct (from acrocladon).

11. Mapplebeckii, Moore (frondoso-cristatum, Jones). Raised in I 866, by Mr. J. E. Mapplebeck. Length, I foot.

*12. Middletoni, Lowe (ramulosissimum Middleton, Wollaston). Found in 1872, in Montgomery, by Mr. Middleton (head gardener to Sir Watkins Wynn). $4 \times 0 \frac{1}{2}$ inches. Branching from the ground into 9 or to branches, more interesting than beautiful.

13. multifurcatum, Moore (ramosissimum, Jones). Found in 1871, at Long Sleddale, by Mr. J. E. Mapplebeck. Length, 15 inches, densely foliose, capitate head 12 inches wide.

14. ramocristatum, Jones. Raised in 1871 , by Mrs. Hodgson. Length, II inches. Ramose, pinnæ crested, width across the head 6 inches.

15. ramulosissimum, Lowe (basi-ramosum, Mapplebeck). Raised in 1870 , by Mr. Mapplebeck. Io $\times 2 \frac{1}{4}$ inches, branching at base of stipes into 6 to so crested fronds.

16. Stansfieldii, Lowe (ramosissimum fimbriatum, Stansfield). Raised by Messrs. F. W. and H. Stansfield. Length, 13 inches. A very fine variety, with naked stipes, head branching to 11 inches across.

17. unco-glomeratum, Jones. Raised in 1878 , by Messrs. F. W. and $H$. Stansfield. General character of acrocladon, but even more branched, finely dissected like the finest forms of "uncum," not fimbriate.

I8. velutinum, Stansfield. A condensed acrocladon, 2 inches high, like a ball of green plush. Raised in 1878 , by Messrs. F. W and $\mathrm{H}$. Stansfield.

\section{Section $\beta$. GRANDICEPS.}

(Terminal crest as wide as, or wider than, frond.)

*I. Albertii, Lowe. Raised by myself. Densely and compactly bunch-crested. Capitate head, $4 \frac{1}{2}$ inches wide. Stiff erect habit. $16 \times 1 \frac{1}{2}$ inches.

*2. Arthuri, Lowe. Raised by myself. Well crested. Length, 16 inches.

3. canaliculatum, Stansfield. Raised in 1882 , by Messrs. F. W. and $\mathrm{H}$. Stansfield. Rachis broad and channelled, hence the name.

4. capitatum, Lowe (nodoso-cristatum, Jones).

*5. caput Medusæ, Mapplebeck. Raised by Mr. Mapplebeck.

*6. centiceps, Lowe. Raised by myself. Length, 15 inches.

*7. ceratophyllum, Mapplebeck. 
*8. coronare, Lowe. Raised by myself; densely crested. $24 \times 3$.

9. coronatum, Moore. Pinnæ acute, not crested, a branching crown $3 \frac{1}{2}$ inches wide. $8 \times 1 \frac{1}{2}$ inches.

10. cristulatum. Stansfield. Raised in $18_{3}$, by Messrs. Stansfield. Ends cristulate ; a branching crest $2 \frac{1}{2}$ inches wide. Length, 8 inches.

II. depauperatum, Moore. Found many years ago near Ben Bulgen, by Mr. J. Gunning. Depauperate, laciniate, crested. Length, 12 inches.

12. Eastoni, Lowe (Grandiceps Eastoni, Jones). Found in I874, at Wythburn, by Mr. J. Easton. Heavily crested.

* 3. eulophon, Mapplebeck. Raised by Mr. Mapplebeck.

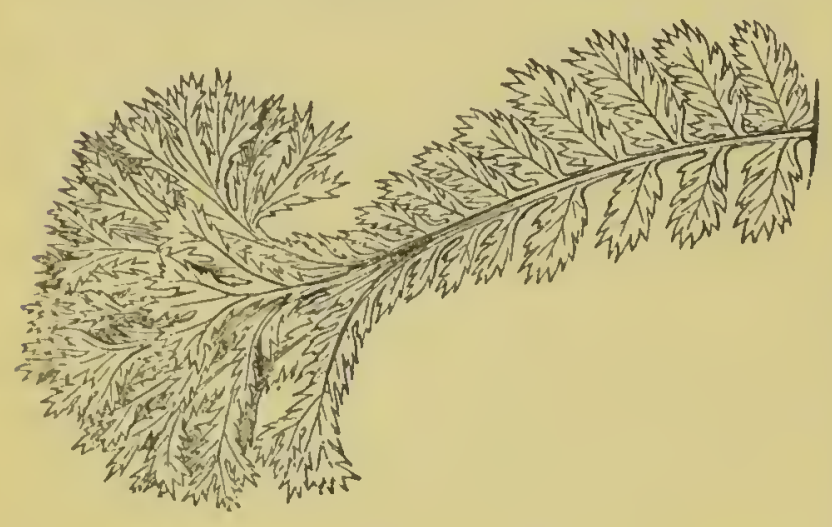

FIG.21. - Pinna of Athyrium Filix-fomina, var. glomeratum (showing bunch-cresting).

I4. glomeratum, Moore. Raised in $1864^{\circ}$, by Messrs. Ivery. Remarkable for the large compact crests and capitate head. $18 \times 5$ inches (in centre of frond).

I5. grandiceps, Hoore. Found near Nettlecombc, by the late Mr. C. Elworthy, and near Wiveliscombe, by Mr. J. Morse. The apex expanded into a large multifid crispy head. Length, 18 inches.

16. Hodgsona, Lotve (Grandiceps Hodgson, Jones). A narrow compactly crested form, dividing into three branches 7 inches from the apex ( 6 inches across these branches). $24 \times 3$ inches.

17. Hookeri, foree. Raised by mysclf, terminating in a crested head 6 inches broad, short crested pinne at the base, then cruciate to the head. $16 \times 2 \frac{1}{2}$ inches (at the base), narrowing to one inch higher up.

*18. Hope, Lowe. Found near Edinburgh, by Lady Hope. An erect-growing, somewhat plumose-crested, and capitate form. length, 16 inches.

*I9. kalon, Lefee. Raised by myself. A grand cruciate and capitate form, the cruciate pinne crested. lleat densely crested, and 5 inches wide. $35 \times 21$ inches.

* 20. keplalobares, Lorve. Kaised by myself. Pinna short and heavily crested, frond terminating in a head five inches wide. lumediately above the basal pair of pinne is a single branch I incl wide and 6 inches long, heavily crested and capitate. $20 \times j$ inclies. 
21. multiceps, Moore. Found near Truro. Multifid crisped. length, $2+$ inches.

22. nudicaule, Lozve (nudicaule cristatum, Jones). An extraordinary variety, branching at the base of the stipes into three distinct fronds, having naked stems, and merely a leafy capitate head, each head $4 \frac{1}{2}$ inches wide. Length, 11 inches.

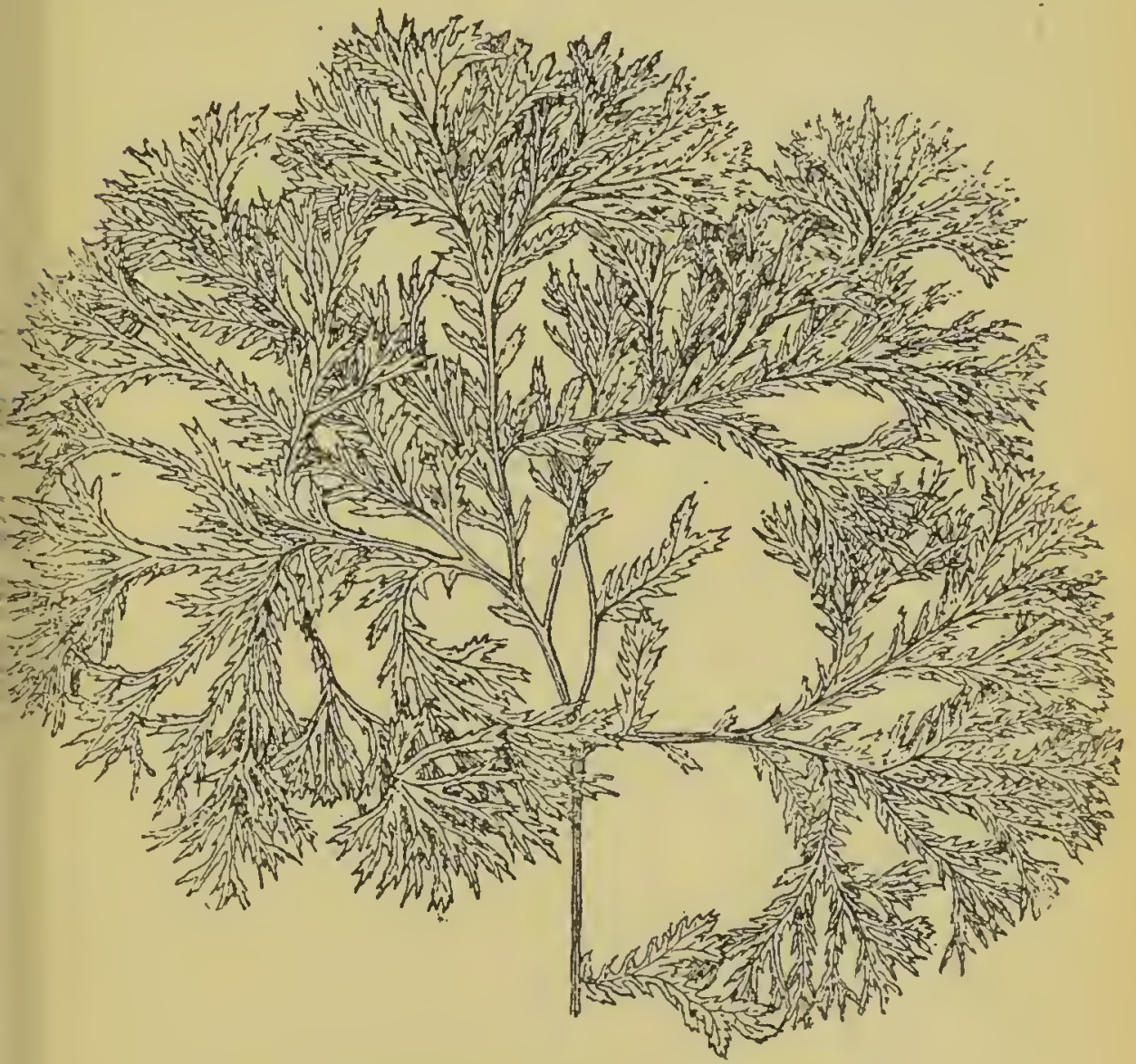

FIG. 22.-Athyrium Filix-fomina, var, orbiculatum (apex).

23. orbiculatum, Lowe (capitatum, Padley). Raised by the late Mr. Elworthy. A very finely-divided large capitate head.

24. Padleyi, Lozve (grandiceps Padley, Jones). A narrow normal form with a dense grandiceps head $4 \frac{1}{2}$ inches wide. $15 \times 2 \frac{1}{2}$ inches.

25. Quilteri, Mapplebeck (inxquale capitatum, Jones). Raised in 1872 , by Mr. Mapplebeck. Branching head $S$ inches broad, below much depauperated. $14 \times 0 \frac{3}{4}$ inches.

26. scopula, Lowe. Raised in 1887 by myself. rachis dividing. Crests like brushes, head 4 inches across. $18 \times 3 \frac{1}{2}$ inches. 
*27 strombomenon, Lozve. Raised in 1867 by myself. Normal with a crested head $5 \frac{1}{2}$ inches broad. $18 \times 4$ inches.

28. triumphale, Lowe. Raised by myself in 1866 . Pinnze and pinnules branching and crested, forming a circular head 7 inches across. $24 \times 4$ inches.

*29. umbraculaforme, Lozue. Raised by myself in 1866. Depauperate, and terminating in an umbrella-shaped head. Length, 12 inches.

\section{Section $\gamma$. CRISTATUM.}

(Bunch crested.)

* I. amenum, Lorue. Very lax, normal at base, pinnules varying strongly dentate, pinna variously crested. $22 \times 7$ inches.

2. angustatum, Lorve (angustato-cristatum, Stansficld). Raised by Messrs. Stansfield. A very narrow cruciate, scarcely crested form. $24 \times I$ inches.

3. anomalum, Love (Gillsoniae anomalum, Mapplebeck). Raised in 1869 by Mr. Mapplebeck. $21 \times 3^{\frac{1}{2}}$ inches in middle of frond. l'innules crowded and margins dentate, tips of pinnx crested, apex of frond caudate. An extraordinary variety.

4. apuxeforme, Barnes. Found in 1870 , at Dent, by Mr. Barnes. Is fish-shaped and crested.

5. caudatum, Lowc (Gillsonire anomalum, Mapplebesk; caudatocristatum, Jones). Raised in $1869.21 \times 3$ inches. Lax, narrow, pinnules dense, apex of frond caudate.

6. corymbiferum, Moore. Found in Guernsey, by the late Mr. James, varying from $18 \times 6$ to $34 \times$ Io inches. A fine form, crested and corymbose.

7. cristatum, Wollaston. Found near Malton, by Mr. Monkman. Apex crested, but not the pinne.

8. curvato-digitatum, Barnes. Found in 1875 , on Lancaster Moor, by Mr. Stewardson. Pinnze curved down and digitate.

9. dactyliferum, Jones. Found in 1874 , at Martindale, by Mr. J. K. Hodgson. Said by the late Colonel James to be distinct.

Io. defecto-furcillans, Mapplebcck. Kaised in 1869 by Mr. J. E. Mapplebeck. $27 \times 9$ inches, pinna: longer and much wider (though with less branches) than Howardie.

*II. densissimum, Mapplebeck.

12. digitale, Joncs. A lax narrow form, pinne with slender, digitate, conspicuous crests. Apex of frond not crested, but ending in a very fine point. $28 \times 6$ inches.

*13. digitatum, Lore. A very bold crested varicty. Raised by myself in $1862.22 \times 5$ inches.

I4. echinatum, Lowe. Short pinna, densely capitate ; the capitate heads 1 inch across, margins conspicuously dentate. Raised by myself. $16 \times 3$ inches.

* 15 Elworthii, Monre. Found near Nettlecombe by the late Mr. C. Eilworthy. 1)ensely tasselled, very symmetrical form, pinnules crested. $30 \times 7$ inches.

16. ericudes, I.oree (Craigii-uncum, Jones). Raised from spores 
(Craigii crossed with uncum). A narrow Craigii. $22 \times 2 \frac{1}{2}$ inches.

17. foliosum, Lozve (folioso cristatum, Jones).

I8. Fosteri, Lowe. Found in Scotland, by Mr. W. Foster, of Salford. Multifurcate fronds.

* I 9. furcillans, Mapplebeck.

20. genmatum, bames. A very interesting narrow variety with reflexed pinnules. Pinne compactly and heavilycrested. $27 \times 4$ inches.

2 I. gracilissimum, Lozve. Raised in 1867 by myself. $2 \mathrm{I} \times 7 \frac{1}{2}$ inches. Slender, with short broad pinnules, pinnæ crested.

22. gratum, Lowe. Raised by myself. Symmetrical crested variety, slender and lax. $20 \times 5$ inches.

23. Hodgsoni, Lowe (apuæforme Hodgsoni, Barnes). Found in I 867 , at Torver, by Mrs. Hodgson. Piunæ and frond fishshaped.

*24. Howardre, Mosre. Raised in 1864 by Mr. Craig (gardener to the late Hon. Mirs. Howard, Levens Hall). $24 \times 7$ inches in centre of frond. Pinnæe branching and cresting, as broad as long, and though lax overlapping from the great breadth of the ramose ends.

25. Huckii, Lowe (cristatum Huckii, Barnes). Found in 5874 , by Mr. T. Huck, at Wet Sleddale. A beautiful variety, with long, crispy, crested pinnules.

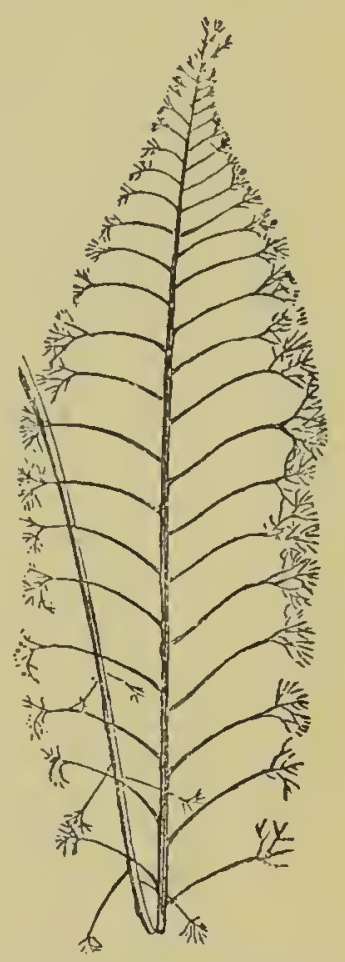

Fis. 23.-Athyrium Filixfoemina, var. Elworthii (showing cresting).

26. inæequale-furcans, Wollaston. Found in 1877 in Lancashire, by Mr. J. Lamb. Very irregular in size, position, and form of pinnæe and pinnules, and partly depauperate. Conspicuously crested. I $8 \times 8$ inches (at base).

27. incongruum, Barnes. Found in 1875 , in Langdale, by Mr. Barnes.

*28. kalliston, Lowe. Raised by myself. A handsome crested form. Length, 2 feet.

29. laxum, Lozve (laxo-cristatum, Phillips). Found at Ballynahincl, Co. Down, by Mr.W. H. Phillips. A small crested fern, with long, narrow, lax pinnules. Distinct. $30 \times 9$ inches.

*3o. magnificum, Lowe. Raised by myself. Grandly crested.

31. Mapplebeckii, Moore (frondoso-cristatum, Jones). Raised by Mr. Mapplebeck in I866. Dark green and sterile. A very fine crested frondose fern.

32. inirandum, Lowe. Raised by myself. Very handsome. $26 \times 6$ inches (lower part), $2 \frac{1}{2}$ inches (upper part). Capitate. Four pairs of basal pinnæe branch-crested, and above this cruciatecrested. 
33. multifidum, Moore. Found in Wicklow, by Mr. D. Moore. $33 \times$ so inches. Normal with crested pinne. There are various wild forms (viz. Barnesii, Hodgsonæe, tenue, Fraseri, nanum), and almost an endless number have been raised from spores.

34 paucidentatum, Lowe (paucidentatum cristatum, Mapplebeck). Raised in 1870 by Mr. Mapplebeck. $16 \times 10 \frac{1}{5}$ inches. A marvellous, delicate variety; very broad. Pinna with large ramose crestings; apex of frond abrupt, with branching crest; pinnules short and scalcely dentate.

35. percristatum, Lowe (percristatum Cousins, Jones). An interesting form.

36. polydactylum, Moore. Found at Windermere, Nettlecombe, and other places. Fingrer crested.

37. regale, Mhore. Raised in 1867 by Mr. J. M. Barnes. $30 \times 10$ inches. The grandest crested Lady Fern; foliose, and the pinnules crested.

38. setigerum, Jones. Found in the Lake district by Mr. Garnett. A grand crested, lax form ; pinnules dilated at the apex, and bristling with hair divisions. $24 \times 5$ inches.

39. spinocristatum, Lowe. A marvellous production, raised from mixed spores. $20 \times 4$ inches. Lax, many pinnx wantings, some reduced to thoms that are crested, the few pinna well crested, a large capitate head.

40. splendens, Moore. Raised in 1864 by Mr. J. M. Baınes. $.30 \times 7$ inches. A fine plumose form, with tips of pinna boldly furcately crested, and pinnules also crested.

41. splendidum, Lorve (splendens Craig, Jones). Raised by Mr. Craig $36 \times$ II inches. One of the finest crested forms. Pinne and pinnules crested. Scarcely distinct from Barnes's form.

42. Stewardsoni, Lowe (digitale Stewardson, Jones). A pretty lax digitate variety. Fronds, $2 \mathrm{I} \times 7$ inclies.

43. tenue, Lowe (cristato-tenue, Wollnston; multifidum tenue, Itil.sm). Found in I869, in North Lancashire, by Mr. J. Wilson. A slencler fern, widest in centre, with narrow, distant, fish-tail crests. $12 \times 4 \frac{1}{2}$ inches.

44. uncum, Lowe. Raised by myself from spores. A copy of uncum, but well crested and capitate. $22 \times 5$ inches.

\section{Section $\delta$. CRUCIATUM.}

\section{(Pinna and pinnules twin branched.)}

*I. Alexandre, Lozve. Raised by myself in $1867.28 \times 3$ inches. The thrce pairs of basal pinna, and also near the forked tip of the frond normal, elsewhere broadly and boldly cruciate.

2. angustum, Lowe (angusto-cruciatum, fones). Raised in $186 \mathrm{~S}$ by Messirs. Stansfield. Smaller than multifidum. $12 \times 0_{2}^{1}$ inches.

3. arbuscula, fowe. Raised by myself. $24 \times 9$ inches. P'mne normal ; pinnules, some cruciate, others depauperate, and part normal.

4. liakeri, Lowe. Raised by mysclf. Narrow, cruciate, with attenuated tip. 
*5. calomelanos, Lowe. Raised by myself. A fine crested form.

6. clarum, Lowe. Raised by the late Mr. Carbonell. $18 \times 5$ inches. Cruciate, both in pinnæe and pinnules.

7. Coeleste, Lowe. Raised by the late Colonel Jones, and in the possession of Mr. E. F. Fox. $18 \times 0 \frac{1}{2}$ inclies. Very narrow, cruciate and capitate.

*8. columnare, Lowe. Like crested columns.

9. contrarium, Lowe Raised by the late Colonel Jones. $26 \times 2$ inches at base, gradually narrowing to half an inch. The 3 or 4 pairs of basal pinnæ long, narrow, and reflexed, above these more or less horizontal cruciate pinnæ, and near the apex lunulate; frond ending in a narrow, pendent apex. A fine variety.

ro. coronans, Lowe (cruciato-coronans, Stansfield). Raised abo.tt I88+ by Mr. W. C. Carbonell. Dwarfer than Victorixe with a more crown-like crest; cruciate character replaced in upper half of frond by extreme sporting of pinnx.

*II. Craigii, Moore (crucipinnulum cristatum Craig, Fones). Raised in I 864 by Mr. R. Craig. $8 \times 1$ inches. Stem red. Pinnxe and pinnules varied in size and shape, apex very leafy and crested. * I2. Craigii-glomeratum, Mapplebeck. Raised by Mr. Mapplebeck. A conglomerate form.

* I 3. Craigii-splendens, Mapplebeck. Raised by Mr. Mapplebeck.

14. crucere, Lonve. Raised by myself in I887. Cruciate, pinnie crested, apex capitate.

I 5. cruciato-multifidum, Praeger. Found in I8So at Castlerock, Co. Derry, by Mr. A. J. Praeger. $20 \times \frac{1}{2}$ to $4 \frac{1}{2}$ inches. Lower half cruciate, upper normal, but crested.

16. cruciato-pinnula, Phillips. Found at Holywood, county Down, by Mr. WV. H. Phillips. $30 \times 9$ inches. Pinnæ truncate, pinnules on upper half of frond cruciate.

17. cruciferum, Lozee. From the late Colonel Jones's fronds. Length 20 inches, width $\frac{3}{4}$ of an inch, cruciate from the base to the densely tasselled apex. Pinnze in lower half of the frond crested and longer; but, lying parallel with the rachis, the frond is not wider. A pretty variety.

I8. delicia, Lowe. Raised by myself in I887. A fine cruciate form with cruciate pinnules.

19. Dyeri, Lozve. Raised by myself. A narrow cruciate capitate elegant form.

*20. elegans, Loze (Victorix gracile, Fones). Raised by myself. A very slender Victoriæ. $2 \mathrm{I} \times 3$ inches. Pinnæ narrow (linear) pinnules minute, having the appearance of rows of thorns.

21. Evelyna, Fox: Raised by Mr. E. F. Fox. A distinct form of Victoria, $30 \times 1 \frac{1}{2}$ inches. The cruciation parallel with the rachis, conspicuously bidentate.

*22. exempluum, Lowe. Raised by myself. Length 15 inches. Pinne narrow, the basal 2 or 3 pairs at right angles to the rachis, the rest of the pinnec cruciate, the frond narrowing to a point. The whole of the pinnules arc cruciate, and this gives the frond an elegant appearance. 
23. Fieldx, Moore (cruciatum Miss Field, Fones). Found by Miss Field. $24 \times 1$ inches. Cruciate, and unbranched apex.

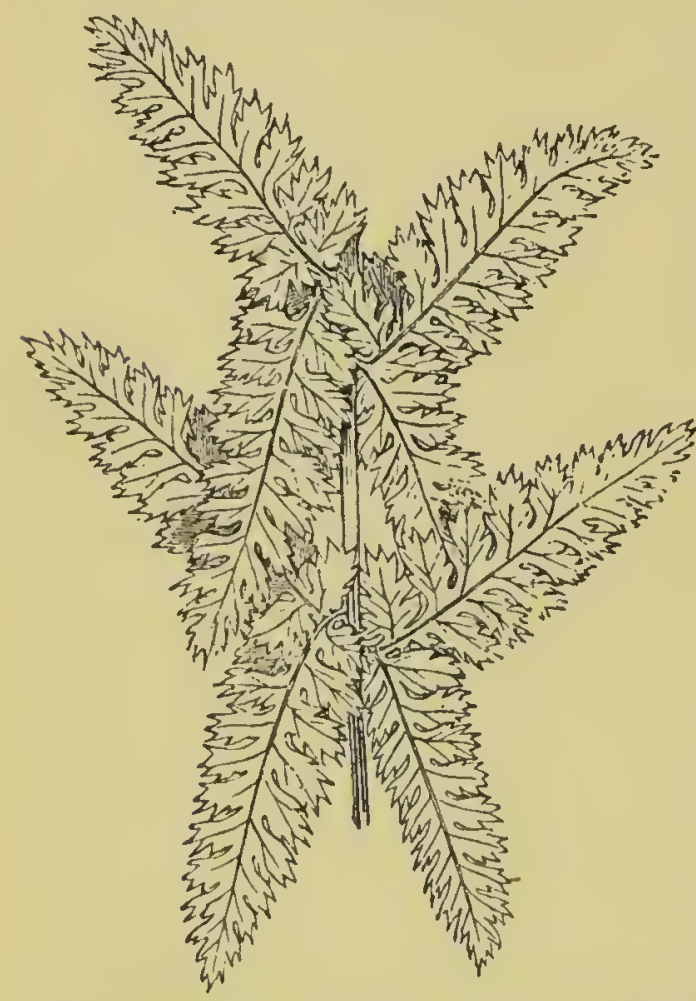

24. gemelli para, Lowe. Raised by myself. $30 \times 4$ inches below and $\times 2$ inches above. A handsome combination. Lowest 4 or 5 pairs of pinnæ crested, their pinnules cruciate ; above pinne cruciate and the crested apex capitate.

25. glomeratum, Lowe (cruciato - glomeratum, Stansfield). Raised in I 878 by Messis. F. IV. and $\mathrm{H}$. Stansfield.

*26. Gilsonæ, Mapplebeck.

*27. Gilsonæ - furcans, Mapplebeck.

*28. Gulsonæ, Lozve. Raised by myself. A narrow cruciate form, having a narrow, nomal apex to the frond. Length 20 inches.

29. Halla, Lorue. Raised from spores in I869 by myself, lower Fig. 24- - Middle portion of frond of Asplenium Filix - half of the frond normal foemina, var. Fielda (showing cruciate character). and crested; centre of frond, pinnæe dividing in the middle; above cruciate and crested, apex capitate, $18 \times 5$ inches, and $2 \frac{1}{2}$ inches where cruciate ; raised from "Craigii."

*30. invincere, Lowe. Raised from spores in 1870 by myself. $18 \times 4 \frac{1}{2}$ inches. Lower half of frond normal and denscly crested, above cruciate with a capitate head. Where cruciate, width only $1 \frac{1}{2}$ inches.

31. Jonesii, Lozee (cruciato-cristatum, Fones). Raised in I $\$ 74$, by the late Colonel Jones. $2 \mathrm{I} \times \mathrm{I}_{\mathbf{4}}^{\mathrm{l}}$ inches. A very symmetrical cruciate variety, with crested apex.

*32. Lawsoni, Loze'. Raised by myself. $2 \mathrm{C} \times 0_{4}^{3}$ inches. In style of Frizclliz-cristatm of Jones; but the pinne are cruciate. A large capitate head.

33. Mapplcbeckii, Lowe (cruciato-multifidum Stansfield, Wollaston; and Fieldie-fimbriatum, Moore). Raised in 1867 by Mr. J. E. Mapplebeck. Length 2 I inches.

34. mixtum, Lowe. A narrow, very slender form, raised by myself in 1887 . Length 20 inches, width .3 inches where poly- 
dactylous, and I inch where cruciate ; near the base polydactylous, and the superior basal pinnule brachiate.

35. multifidum, Lowe (cruciato-multifidum, Wollaston). Raised in 1865 by Messrs. Stansfield. $22 \times 1 \frac{3}{4}$ inches. Cruciate, apex crested. A crested Pritchardii.

36. nanum, Lozve. Raised by myself. A pretty dwarf cruciate form with a finely cut capitate head. Length 9 inches, width $\frac{1}{2}$ an inch, head 2 inches across.

37. Nereidæ, Lowe (cruciato-cristatum Lowe, Wollaston). Raised in 1873 by myself. Cruriate throughout the frond; pinnæe and also pinnules crested; capitate crested head. $18 \times 1 \frac{3}{4}$ inches.

38. nutamen, Lowe. Raised by myself. A narrow cruciate variety. Length 21 inches, width 1 inch. Apex weeping.

39. peculiare, Lowe. Raised by myselt. A leafy Victoriælike form, $26 \times 3$ inches. Tips of frond and pinnæ pointed.

.40 percruciatum, Lowe. A narrow, slender, conspicuously cruciate variety, with a branched apex. Raised from spores. $14 \times 1$ inches.

4I. Phillipsii, Stansfeld (cruciato-pinnula Phillips, Fox). Found in 1864 , in County Down, by Mr. W. H. Phillips. $21 \times 6$ inches. Normal (truncate and lax); pinnules cruciate. An interesting fern.

42. Praegeri (cruciato-pinnula, Praeger). Found in 1880 at Castlerock, Co. Derry, by Mr. A. J. Praeger. Pinnules cruciate. $22 \times 5$ inches.

43. Pritchardii, Stansfield (cruciatum Pritchard, Fones). Found in $186 \mathrm{r}$, near Ruthin, by Mr. T. Pritchard. $40 \times \mathrm{I}$ inches. Cruciate.

44. projectum, Lowe. A narrow, cruciate, crested capitate form, with here and there projecting non-cruciate pinnæ. Raised by myself. Length 15 inches; width where cruciate, I inch, where projecting, 3 inches.

* 45. proteoides I.owe. Raised from spores by myself from Mr. Clapham's "proteum." A much finer cruciate form, with projecting pinnæ, length 25 inches, width 3 to 5 inches. Habit erect, fronds stiff, and every frond alike. In Colonel Jones's "Nature-printed Ferns," proteoides is figured under the name "proteum."

46. proteum, Clapham. Found in Cumberland in 1866 by the late Mr. Clapham. Half the fronds narrow and cruciate, and half normal. $2 \mathrm{I} \times 4 \frac{1}{2}$ inches.

*47. regale, Love (Victoria magnificum, fones). Raised by myself. $25 \times 5 \frac{1}{2}$ inches. Pinnules lobed; pinnæ broader than in Victorix, $2 \frac{1}{2}$ to 3 inches in length, forming open squares $I$ inch in diameter:

48. reticulum, Lowe. Raised by myself. A narrow, profoundly dentate, cruciate variety. Length 20 inches, width $1 \frac{1}{4}$ inches, apex pointed.

49. Stableri, Lowe (cruciato-pinnula Stabler, Fox). $22 \times 7$ inches middle of frond (where widest). Pinnæ crested and apex of frond caudate. Raised in I 868 by Mr. G. Stabler, of Levens. 
50. Stansfieldii, Lowe (cruciato multifidum Stansfield, W'olluston). Raised in 1865 by Messrs. Stansfield. Apex capitate, $22 \times$ I inches.

51. Striguilense, Lowe. Raised by myself. A bold form, and a giant variety. $36 \times 1$ inçhes.

* 52. strombomenon, Lorve. Raised by myself. Length, I 4 inches. Pinnæ on lower half of frond reflexed, on upper half cruciate and truncate, the apex twisted round to the shape of a ball.

53. transformatum, Lowe. Raised by myself in 1887 . A form of proteoides.

*54. triumphale, Lowe. Raised in I 866 by my.self. Like a narrow Craigii, with a large symmetrical capitate head, 7 inches across; the tips of the cruciate pinnæ boldly crested. $18 \times 4 \frac{1}{2}$ inches, and where cruciate only $2 \frac{1}{2}$ inches.

*55. trossulum, Lowe. Raised by myself, a very pretty cruciate form (a cross with Victoria). Length 17 inches.

56. truncatum, Lowe (cruciato-truncatum, fones). Raised by myself. Bold, pinnules larse and lunulate, apex truncate, $15 \times 6$ inches.

*57. uncum, Lowe (uncum-cruciatum, fones). Raised by my-self. A cruciate uncum.

58. Victoria, Moore. Found in $\mathbf{1} 86 \mathbf{I}$, in Stirlingshire, by Mr.J. Cosh. $20 \times 5$ inches. Pinna narrow, the cruciation forming a number of square openings. A remarkable form.

59. Victoriæ-gracile, Mac $N^{\prime} z b$. Raised at the Edinburgh Botanical Gardens, about I870, by Mr. James Mac Nab. Almost identical with Victoria elegans, Lowe.

\section{Group II. Pumilum.}

(Skeletal axis shortened in relation to soft parts.)

Section a. CONGESTUM. (Main axis shortened.)

I. angustatum, Lorve (angustato congestum. Stansficld). Raised in 1872 by the late Mr. A. Stansfield. A cross between stipatum and Craigii.

2. Cathedrale, Lowe (Simpsonii cristatum, Jones). A crested Simpsonii, said to have been found on Lichfield Cathedral 200 years ago?

3. collectaneum, Lowe. Raised by the late Colonel Jones (in Mr. E. F. Fox's collection). $7 \times 4 \frac{1}{2}$ inches. Very distinct, dwarf, cuneate, depauperate, and digitate; pinne crowded.

4. cristatum, Lozue. Raised by myself. A densely crested capitate form, very much dwarfed ; neat. $8 \times 2$ inches.

5. curtum-cristatum, Stansficld. Raised in 1871 at Todmorden.

*6. Lidwardsii, Love (congestum-minus Edwards, Fon's). Found in lreland many years ago, by the late Mr. Kiley. l'inna crowded and crisp. $9 \times 2 \frac{1}{2}$ inches.

*7. Eclwardsii ramosum, Loree. Similar to Edwardsii, with the addition of branching at the apex.

S. excurrens, Lorve (congestum excurrens, Sirusficld). 
9. Findlayanum, Stansfield (congesto-cristatum, Wollaston). Raised in 1870 by Messrs. Stansfield. $16 \times 2 \frac{1}{2}$ (in centre). Flexuose, foliose, and crested.

10. Fittii, Lowe (congestum cristatum Fitt, fones). A dwarf crested congestum, raised by Mr. Fitt. Very much like Findlayanum.

II. grandiceps, Lowe (congestum grandiceps, Stansfield). Raised in 1885 from Fittii.

12. Grantre, Moore (congestum Paul, Wollaston). Found in 1865, in Cornwall, by Mr. Paul, of Truro. Pinnx and pinnules over-lapping, densely frondose; stipes and rachis very stout, the latter somewhat flexuose ; crispate. $23 \times 6$ inches.

I3. Hodgsonx, Lowe (congestum, Barnes). Found in I863 at Gillbanks by Mrs. Hodgson. A beautiful variety with dense crispy pinnules.

I4. laciniato-cristatum, Lowe (congestum laciniatum cristatum, Stunsfield). Raised in 1886 at Pontefract.

I5. laciniatum, Lowe (congestum laciniatum, Stansfield). Raised in 1872 at Todmorden. A cross between stipatum and laciniatum.

I6. minimum, Birkenhead. Found at Grange, Lancashire, by Mr. Mason. Height only 6 inches.

I7. nanodes, Lozve. Found in Monmouthshire by Mrs. Bagnall Oakeley. $24 \times 4 \frac{1}{2}$ inches (the stipes being 6 inches). Stipes bending, rachis flexuose, pinnæe almost imbricate.

18. Phillipsii, Lowe (congestum Phillips, Phillips). Found in Co. Antrim in 1888 by Mr. W. H. Phillips. $16 \times 6$ inches. Very leafy.

I9. ramulosum, Lowe (angustato ramulosum, Stansfield). Raised about 1876 at the Todmorden Nurseries.

20. Simpsoni, Stansfield (congestum Simpson, fones). A dwarf, stiff, crisped variety, found by Mr. T. Simpson in Lancashire in I 869.

2I. stipatum, Moore (congestum Paul, fones). Found at Dolgelly in 1864 . Dwarf, with very thick stem.

\section{Section $\beta$. CRISPATUM.}

(Subsidiary axes shortened more or less.)

I. apicale, Moore. History obscure. A beautiful variety somewhat like Vernona-cristatum.

2. Barnesii, Lowe (Crispatum Barnesii, Bames). Found in 1863 at Underbarrow. Robust, with long crispy fronds. Mr. Crossfield found at Arnside a form with short fronds.

*3. comicum, Mapplebeck. Crispy, pinnules irregular.

4. conioides, Appleby. Found near Doncaster by Mr. S. Appleby. Length, 2 feet. Named from the outline and divisions of the frond resembling hemlock leaves. Mr. Praiger has found a nice form in Co. Antrim.

5. conioides-cristatum, Stansfield. A crested fern raised by Messrs. Stansfield.

6. Vernonx, Jervis. Found by Miss Vernon. $18 \times 4 \frac{1}{2}$ inches. Divisions frilled. 
7. Vernonze corymbiferum, Stansfield. Raised in 1877 at Todmorden. Apicale is practically identical.

*8. Vernonæ-cristatum, Mapplebeck (crispato-cristatum, Jones). Raised in 1873 by the late Colonel Jones. $18 \times 4$ inches. Pinnules overlapping and crispate, pinnze lax, short, very broad and well crested.

\section{Group III. Flexuosum.}

Section a. FLEXUOSUM. (Bending.)

I. adulterum, Lowe. An extraordinary and beautiful mixed narrow variety. $17 \times 2 \frac{1}{2}$ inches Lower half of frond pinnze very gracefully flexuose; above this cruciate, with flexuose pinna, and near apex normal ; pinnules more or less reflexed throughout. Another of the cruciate batch of seedlings raised here.

2. Craigii, Lowe. Not unlike Harrisæ but larger (one of $\mathrm{Mr}$. Craig's seedlings). Pinna flexuose, and crested. Pinnules long and reflexed; tip of the frond crested. $21 \times 7$ inches.

3. Crossfieldii, Lozve (flexuosum, Moore). Found in 1862 in Silverdale by Mr. J. Crossfield. Twisted, flexuous, and grotesque.

4. cruciato-reflexum, Praeger. Found at Castlerock, Co. Derry; by Mr. A. J. Praeger. $25 \times 5$ inches. Cruciate and reflexed.

5. cruciatum, Lowe. Raised from spores. Length 24 inches, width $4^{\frac{1}{2}}$ inclies. Pinnze narrow, flexuose, and cruciate; more regularly cruciate in upper half of frond, and apex capitate. This was from a mixture of spores (Frizelliae, Foxii, cruciatum, and uncum); and all these forms are shown in the frond.

6. cymba, Lozve. Raised by my'self. IS $\times 5 \frac{1}{2}$ inches. The pinnæ curve upwards (boat-like) and are heavily crested; pinnules tortuous and are turned down wards.

7. flexuosum, Wollaston. Found in 1858 in Lancashire by $\mathrm{Mr}$ Huddart. The stipes, rachis, pinnæ, and pinnules twisting in most grotesque manner, varying much in the manner of twisting $18 \times 5$ inches.

8. Foxii, Lowe (reflexum Fox, Wollaston). Found in 1850 in South Devon by Mr. E. F. Fox. A much narrower variety that reflexum, with the same revolving character; tips of pinne reflexing giving a hooked look. $27 \times 4$ inches.

9. Harrisa, Lowe. Raised by myself. Rather broader that Foxii, and the tips of pinnae minutely crested.

* Io. lineare, Lozve (lineare reflexum, Lorec). Raised in sam batch of seedlings with cruciatum; $16 \times 2 \frac{1}{3}$ inches; to above th middle of frond; pinnse one incli apart; upper third of fron cruciate with minute lunulate pinnules.

I1. perplexum, Loave. Raised by myself. $27 \times 3$ inches (thoug some pinne five inches long). Remarkably depauperate an very nexuose. Pinnae mostly on one side, and in pairs almotouching cach other; some pimne crested; many pinnul wanting, and most lunulate and minute.

12. plumosum, Jones. A flexuose plumose form found in Count Kerry by the late Mr. Tyermam. $20 \times 4$ inches. 
5. decoratum, Lowe. From the late Colonel Jones's collection. History not known. A subplumose, narrow, lax form ; very symmetrical. A great benuty. $23 \times 6$ inches.

*6. dilatatum, Mapplebeck. Rather foliose.

7. divaricatum, Lorve (plumosum-divaricatum, Noore). Found in 1872 in Lancashire by $\mathrm{Mr}$. IV. Morris. Pinnules almost perpendicular to the main stem. A very fine divaricate plumosum. $30 \times 12$ inches.

8. elegans, Lozve (plumosum-elegans, Parsons). Raised by Mr. Parsons. Slender, with finely cut pinnules. $28 \times 7$ inches.

9. foliosum, Druery. Found at Ilfracombe in $18 \$ 1$. A true foliosum.

10. frondoso-cristatum, Jones (in the late Colonel Jones's collection).

I1. Hodgsonæ, Lowe (subplumosum Hodgson, Jones). Found by Mrs. Hodgson in i 870 near Ulverston. A very slender featherlike fern. I $6 \times 6$ inches. Very lax; with beautiful pinnules, finely cut.

I2. kalothrix, Lowe. Raised in 1870 by Mr. Howlett. is 86 inches. A most lovely, delicate, pale-green, hair-like form.

*13. Longridgense, Lozve. A subplumose form found on Longridge Fell in 1846 by myself. A large and graceful variety. $30 \times 12$ inches.

14. multifidum, Lorve (plumoso-multifidum, Stansfele'). Found about 1860 on Ben Lawers by Mr. IV. Marshall. A feathery form of multifidum.

15. plumosum, Nonre. Found in Yorkshire in 1860 by Mr J. Horsfall. A fine plumose variety. $33 \times 8$ inches.

16. Smithii, Lowe (plumosum Smith, Jones). Length 20 inches. width 12 inches. A handsome fertile plumosum variety. Found by Mr. Smith in Darley Dale.

17. Stansfieldii, Lowe (plumosum-Stansfieldii, Sternsficli). Raised by Messrs. Stansfield from kalothrix; a larger and less fragile form than that lovely variety. A most beautiful plumosum.

IS. subplumosum, Padley. Found near Nettlecombe by the late Mr. C. Elworthy. $26 \times 8 \frac{1}{2}$ inches. A very elegant plumose form.

* 19. superbum, Lowe (plumosum-superbum, J)ruery). Raised by Mr. C. T. Druery. One of a number of lovely ferns raised by Mr. Druery.

20. Thompsoni, Lorve. A singular plumose form, the pinne furcating near the ends, and the tips being caudate. Found at Mousehole, Cornwall, by Mr. R. A. Thompson. $24 \times 7$ inches. $A$ pex furcate.

21. Willsii, Lowe (plumosum Wills, Joncs). Found in Dorset in 1869 by Mr. J. S. Wills. Very robust. Mir. Wills hat a plant 6 feet high and as much wide.

\section{Section $\beta$. DISSLCTUM.}

(Subdivision of ultimate segments without marticd increase in development of soft parts.)

1. Barnesii, Clapham. Raised by Mr. Larnes, of Thirsk. Somewhat in the way of pulcherrimum, though distinct. 
2. coronatum, Lowe (setigerum-coronatum, Birkenheal).

3. corymbiferum, Lowe (setigerum corymbiferum, Birkenhead).

4. cristatum, Lowe (pulcherrimum cristatum Hodgson, Jones). A crested form of pulcherrimum found in the Lake District by Mrs. Hodgson.

5. diffissum, Moore. Found originally in Guernsey by the late Mr. James. Length 18 inches. Pinnules irregularly cut.

6. elegans, Phillips. Found at Duneight, Co. Antrinı, by the Rev. W. D. Pounden. I $8 \times 6$ inches. A fragile form.

7. gracile, Phillips. Found at Inch, Co. Down, by the Rev. W. D. Pounden, also in Antrim by Mr. Phillips. $20 \times 6 \frac{1}{2}$ inches. A slender form.

8. grandiceps, Lowe (setigerum grandiceps, Birkenhead).

9. Jacksoni, Lowe (pulcherrimum plumosum, Jones). A plumose form of pulcherrimum found by the late $\mathrm{Mr}$. Jackson.

* Io. Lowx, Lowe. Raised by myself. Normal in form, fronds and pinnæ concave. Length, I6 inches.

*11. Lowr-angustatum, Loze. Raised by myself. Differs in the fronds being very narrow.

12. pulcherrimum, Jones. Raised in 1868 , by Mrs. M. A. Walke. $14 \times 4 \frac{1}{4}$ inches. A pretty divarf, feather-like fern.

* I3. rectangulare, Moore. Found in I870, in Westmoreland, by Mrs. J. Wilson. $2 \mathrm{I} \times 8$ inches, in centre of frond. Apical pinnules bidentate; pinnules so small that the spore-cases are wider. A very pretty variety. Doodioides Lowe is very similar.

14. setigerum, Wollaston. Found in 1878 , in Lancashire, by Mr. Garnett, nurseryman, Bowness. $20 \times 6$ inches, in centre of frond. An exquisitely divided form.

15. spinosum, Lowe. Raised by myself. $15 \times 5$ inches. Pinnules deeply split into very dentate thorny lobes.

16. todeoides, Stansfield. Large and very finely dissected.

*I7. todeoides superbum, Lowe. Raised by myself. Length, 24 inches.

\section{Group II. Exiguum.}

(Regular diminution of soft parts.)

Section a. LAXUM. (Pinnæe wide apart.)

I. fœcundulosissimum, Wollaston. Raised from uncum-cristatum in 1882 by Mr. C. T. Druery. Dwarf, densely crested, and the crests crowded with bulbils.

2. laxo-cristatum, Phillips. Found at Ballynahinch, Co. Down, by $\mathrm{Mr}$. W. H. Phillips. $2 \mathrm{I} \times 7$ inches. Pinnules linear; pinnae crested tips. Distinct.

3. lineare, Lowe (uncum-lineare, Jones), a very narrow uncum, raised by the late Colonel Jones. $12 \times 1 \frac{1}{2}$ inches.

4. pannosum, Moore. Found in a number of places. Slender ; pinnules irregular and tapering.

5. scitum, Lowe. Raised in 1877 by myself. A narrow, neat uncun. Pinne slightly crested, apex of frond ramose and crested. 
$2+\times 3$ inches in the broadest part, only $\frac{3}{4}$ inch at the base, and below the branched head.

6. uncum, Moore. Found in 1860 , in Levens Park, by Mr. J. M. barnes. $10 \times 3$ inches. Pinne narrow and lax; pinnules varied, although having a general resemblance; divided to the costa and often bent like a hook.

7. Woodii, Lorve (curtum-Woodii, Wollaston). Found in I865, at Bowness, by Mr. J. Wood. I I $\times 2 \frac{1}{2}$ inches. Regular outline, compact and leafy:

\section{Section $\beta$. DEPAUPERATUM. (Irregular, part wanting.)}

I. abasilobum, Phillips. Found at Ballywater, Co. Down, by Mr. W. H. Phillips. $24 \times 11$ inclies. Basal lobe wanting; pinna linear caudatc.

*2. abasiphyllum, Lowe. Found in Ireland by the late Rev. C. Padley. Length 14 inches. Habit somewhat prostrate; differs in the absence of the basal pinnules.

*. amonum, Mapplebeck. Defective.

4. capitatum, Tyerman. A form very much like cephalomanes was raised by the late Mr. Tyerman.

5. cephalomanes, Jones. Raised from spores. Length 14 inches. Normal reflexed crested pinnx at the base ; above this pinnæ absent ; apex capitate, the head five inches broad.

*6. defecto-sectum, Mapplebeck.

*7. Du Boula, Lowe. Found in Cornwall by Mrs. Du Boule, and sent to Mr. Sang to raise plants from spores, in order to realize money towards restoring $\mathrm{Mr}$. Du Boule's church. Unfortunately the seedlings would not come true from spores. $22 \times 4$ inches. A singular depauperate and laciniate variety.

8. excurrens, Moore. Found in 1853 at Tunbridge Wells, differing in the tips of the pinne having transparent hair-like points.

9. interruptum, Moore. Found near Nettlecombe, by the late Mr. Elworthy. $26 \times 7$ inches. Pinna very various; pinnules much depauperated. A singular form was found near Ambleside by Mr. G. B. Wollaston; and Mr. W. H. Phillips has found two good forms, one at Carlingford and the other at Killymoon.

Io. medio-deficiens, Jones. Found in 1884 at Innerwell, Wigtownshire, by Mr. C. T. Drucry. Outline symmetrical; basal pinnules ( 2 to 6 pairs) in all the micldle pinnxe depauperate.

I1. polymorphum, Clapham. Found in 1872 near Scarborough, by Mr. Keld. l'inne and pinnules depauperuted; many pinnules absent, and some branched and others confluent; somewhat crested ; a tail-like depauperate apex of frond. A singular fern. $18 \times 7$ inches.

*12. secare, Lrave. Raised by myself. A narrow depauperate form, with pinna and apex of frond truncate. Length, 16 inches.

*13. Sylvia, Lonee. Ratised by myself. A slender depauperate variety, with diverse pinnat and pinnules; retlexed. $15 \times 2 \frac{1}{2}$ inches. The larger pinnules confluent. 
Group III. Heteromorphum.

Section a. ROTUNDATUM. (Rounded pinnules.)

1. capitatum, Lowe (Pulleri-capitatum, Jonss). Raised by Mr. E. F. Fox. A capitate Pulleri.

*2. cymbaforme, Loive. Raised by myself. A cross between Pulleri and cruciatum. In lower half of fronds, which are lax, each pair of pinna curve upwards and assume the shape of a boat; above the middle of frond cruciate, and towards the apex Frizellia-like. The upper half of each pinna is lunulate, terminating in a large lunulate pinnule, as broad as the rest of the frond. $20 \times 4$ inches at base, and $20 \times 0 \frac{1}{4}$ inches near apex.

*3. Fraseri, Lowe. Raised from spores by myself. Quite distinct from Pulleri, with larger and less rounded pinnules. Truncate and branched at the apex. Length, 22 inches, width, $2 \frac{1}{2}$ inches.

4. Pulleri, Moore (rotundatum, Wollaston). Found in 1864 in the Isle of Skye by Mr. C. Puller. Length, $18 \times 3$ inches. Very lax, pinne short and narrow, with lunulate pinnules; tip of frond caudate. A distinct fern. I have raised a form from this, fronds 6 inches broad, and pinnules of double the size of Pulleri.

\section{Section $\beta$. LINEARE. (Narrow pinnules.)}

I. diminuato-pinnulum, Lowe. Raised by myself in 1884 . I $8 \times 7$ inches. A slender variety, with very small, reduced pinnules, broader than long.

*2. Flexile, Mapplebeck. Narrow.

3. Girdlestoni, Ivery (lineare, Wollaston). Found in 1866 in Rosshire by the Rev. Canon Girdlestone. Length, 2 I $\times 9$ inches. Pinnæ ascending, linear or depauperate, especially near the rachis, where the pinnules are reduced to a thorn, or wanting. Apex of pimnules confluent.

Section $\gamma$. LACINIATUM. (Jagged pinnules.)

I. arbuscula, Lowe. Raised by myself.

**2. Bellairse, Lozue. A dwarf laciniate form. Found by Miss Bellairs. Length, 10 inches. Pinnae and pinnules diverse.

3. conioides, Appleby.

4. elegans, Lowe (laciniatum elegans, Stansfield). A sport from ramulosum. The ramulose apex has disappeared, and is replaced by cruciate pinnules.

5. Fosteri, Lorve (laciniatum Foster, Fones). Found at Woodhead, in 1879 , by Mr. Foster. An interesting laciniate Kalothrixlooking depauperate form. Pinnules cut into hair-like segments. $15 \times 5$ inches.

6. Jonesii, Barnes. Found in $186 \mathrm{r}$, at Farleton Knot, by Mr. J. J. Jones. Dwarf, laciniate, abrupt fronds.

7. multicuspe, Moore. Found in IS6I, in Levens Park, by Mr. Barnes. Pinnules many pointed.

8. multifidum, Lorve (tortile multifidum, Stansfielt). Raised in I886, at Todmorden. 
9. polydactylum, Lowe (laciniatum polydactyhum, Stansfield). Raised about IS85, by Messis. F. W. and H. Stansfield.

Io. ramulosum, Lozve (laciniatum ramulosum, Stansfield). Raised in 1872 , at Todmorden, between Craigii and Horsfallii. Some fronds plumose, others multifid.

*I1. Rickettsx, Lorve. Found by Mrs. Ricketts. A narrow laciniate form. Length 12 inches.

12. tortilc, Moore (inæquale, Wollaston). Found in 1858 , in Yorkshire, by Mr. J. Horsfall. A symmetrical but laciniate form. An interesting variety. $24 \times 7$ inches.

13. tortiloides, Lowe. Raised by myself in $1887.22 \times 3 \frac{3}{4}$ inches (in middle of the frond). A combination of fissidens and tortile.

\section{Section $\delta$. LUNULATUM (or FRIZELLE).}

(Pinnæ abbreviated to lobes.)

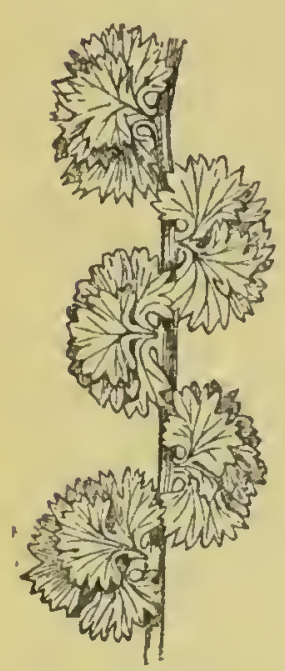

Fir. 26. - Athyrium

Filix-foemina, var. Frizellia.

1. capitatum, Lozve (Frizelliae cristatum, Fones; lunulato-cristatum, Wollaston). Raised in 1875 , by the late Colonel Jones. $24 \times 0^{\circ} 2$ inches. Pinne smaller than in Frizellix, terminating in a compact capitatc head 5 inches wide. From the branching of this crested head there is a complete change in the character of the segments. I have raised an identical form.

2. Carbonellii, Lowe (Frizellixe capitatum, Carbonell). Raised by the late Mr. Carbonell. $14 \times 0 \frac{1}{9}$ inches. A narrow capitate form.

3. C̈lovellianum, Lorve. Found in 1884 , at Clovelly. $16 \times 0^{\circ} 3$ inches. Somewhat of the character of Frizellia, though quite distinct and has a cuncatc-crested apex.

*4. roronare, Lozwe (Frizellia-coronare, Burkenhead). Nicely crowned.

5. cruciatum, Lowe. Raised from spores by myself. Narrow, cruciatc, and capitate. $25 \times 0 \frac{1}{2}$ inches ; capitate head $5 \frac{1}{2}$ inches across. Head dense and foliose.

6. dentato-capitatum, Lorve. Not unlike dentatum but broader fronds, longer teeth, and a capitate dentate head. $16 \times 1$ inches at base, and $16 \times 0$ inches in upper half.

7. dentatum, Lowe. Raised from spores (of uncum, cruciatum, and Frizellis). Combining the characters of all; below uncum, then cruciatum, ending in Frizellice ; cverywhere decply dentate. $16 \times 1 \frac{1}{2}$ inches at base, and $16 \times 10$ inches near apex.

*8. flabcllifolium, Mapplebeck.

*9. flabellifolimm-cristitum, Mapplebeck.

10. Frizclla, Moore (hunulatum, Wollas/on). Found in IS57, in Co. IVicklow, by Mrs. Charles Frizell, of Castle Kevin, and 
subsequently in Co. Donegal, by Mr. H. C. Hart. Very narrow with half-moon shaped pinna. $15 \times 0 \cdot 3$ inches.

II. gracile, Lowe (Frizellae gracile, Birkenhead).

12. grammicon, Lowe. Raised from spores. Bushy habit. $\mathrm{I} 8 \times \mathrm{I}$ inches.

I3. Helena, Fox. Raised by Mr. E. F. Fox. $15 \times 2$ inches. lower half branch-crested; upper pinna all but wanting. Cuneate branched apex.

I4. lunuloides, Lozve. Raised by myself. $\mathrm{I} 2 \times \mathrm{I} \frac{1}{4}$ inches. Upper half of frond pinnæ lunulate but confluent, apex truncate.

15. multifidum, Lozee (Frizellae multifidum, Barnes, lunulatomultifidum, Wollaston). Raised in $187 \mathrm{I}$, by Mr. Barnes. $18 \times 0^{\circ} 2$ inches. Pinne smaller and more abortive than in Frizellix. Frond terminating in a capitate head 9 inches across. The tips of the numerous branches crested, the crests being of a different character. I have raised one almost identical.

16. ramosissimum, Lowe (Frizella ramosissimum, Mapplebeck; ramulo-lunulatum, Wollaston). Raised in 1873 , by Mr. Mapplebeck. Length, 4 inches, width across the ramose head, 5 inches. A mass of branches (as many as 17 ) starting at the stipes.

17. ramosum, Lowe (Frizellæ ramosum, Lorve; and ramo-lunulatum, Wollaston). Raised in 1874 by myself. $12 \times 0^{\circ} 3$ inches. Branching from the rachis, each branch representing the top portion of Frizellix.

I S. sagittatum, Lorve (sagittato lunulatum, Fones). Raised by myself. Base sagittate, upper part gradually passing into Frizellize.

19. Shawii, Moore. A dwarf Frizellae, with lobes single instead of double, as in Frizelliæe.

*20. spicatum, Mapplebeck.

*21. stellatum-angustatum, Druery. Interesting capitate head.

22. superadornatum, Lowe. Raised by Mrs. Grant, of Hillers. don. The lunulate pinna smaller, and the capitate head larger than in cupitatum, and the plant more robust. $26 \times 0.2$ inches (capitate head 6 inches).

\section{THE COMMON CETERACH.}

\section{Asplenium Ceterach.-Linncus.}

\section{(CETERACH OfFICINARUM.-Willdenozi.)}

A SMALL pinnatifid fern, growing on rocks and walls in a limestone district, mostly on the sunny side; having bluish-green, leathery, numerous fronds varying from 3 to 10 inches in length. The underneath of the frond is covered with reddish, chaffy scales, and the sori, which are more or less hidden by these scales, are linearoblong. It is more abundant and more luxurious in Ireland than in England. During droughts the fronds fold up as if dead, but become fully expanded again after the first shower. Although it is abundant in the southern counties of England, and found in 


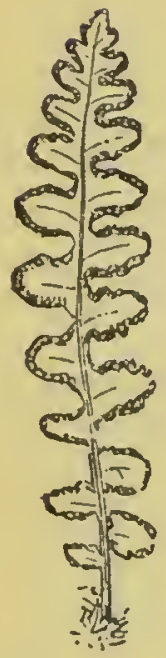

FIG: 27.-Frond of Asplenium Ceterach.

30 English, 7 Welsh, and 7 Scotch counties, it is nevertheless rare in some of them. Years ago a single plant was found by the late $\mathrm{Mr}$. Joseph Sidebotham, on Colwick Park wall, in Nottingham, and a second plant was on the sunk fence wall at Highfield House; but both of these plants are now dead. It had been seen years before in Nottingham Park and at Papplewick, but is destroyed in these places. The Lancashire plants are the variety crenatum. In Ireland it is more or less abundant in fourteen counties, and is also found in the islands of Jersey, Anglesea, Arran, and the Isle of Wight. WVidely spread throughout Europe, and an inhabitant of Madeira, Azores, Canaries, Cape de Verue lsles, India, Asia Minor, Brazil, etc. In Lancashire it is found locally on Pendle Hill, and at Browsholme Hall, near Clitheroe.

In Madeira there is a very similar fern on a much larger scale, known as Ceterach aureum. This I have crossed with the English species, but the secdlings are yet too small to speak about positively. The Barony of the Burren, in County Clare, is extraordinarily rich in varieties, some very large, and some excecdingly distinct. Mr. P. B. O'Kelly, of Glanarra House, Ballyvaughan, has sent me more than a dozen distinct varieties, and all good characteristic plants. Mr. O'Kelly's name is attached to all his Burren forms.

\section{VARIETIES.}

1. angustatum, O'kelly. $2 \times 0 \frac{1}{4}$ inches. Concare.

2. bitidum, O'Kelly. Bifid.

3. crenatum, Moore. Found in Lake district, by Miss Beever ; near Clitheroe, by Mr. Garnett and myself ; Cricklowel, by Mr. J. R. Cobb and myself; Devon, Mr. J. R. Gray; Perth and Kircudbright, by Mr. W. G. Johnstone; Carberry Island, by the late Colonel A. S. H. Lowe; Waterford, by Mr. J. R. Kinahan; but by far the best forms in the Burren, by Mr. O'Kelly. The margin crenate. $6 \times 1 \frac{1}{4}$ inches.

4. crenatum-major, $O^{\prime} K$ clly. $8 \times \mathrm{I}_{4}$ inches.

5. crenulare, Lorve (crenatum minor, O'Kelly). $2 \frac{1}{4} \times 0_{4}^{3}$ inches. Concave, very pretty.

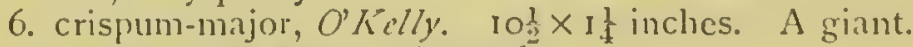

7. cristatum, O'Kelly. Crested.

8. decorum, $O$ 'kelly. Stiffer texture and rugose. $S \times 1$ inches.

9. densum, O'Kelly. $3 \times 03$ inclies.

Io. densum-varians, O'ḱelly'. $4 \times 0_{s}^{5}$ inches.

I I. depauperatum, Wollustom. Found at Killenny, by Colonel Buchanan.

12. giganteum, O'Kelly. $7 \frac{1}{2} \times$ I inches.

I3. grandiceps, $O^{\prime} h c^{\prime l y} .4 \times 0_{s}^{3}$ inches. $\Lambda$ fine capitate form. 
14. interruptum, $\mathrm{O}^{\prime} \mathrm{K}^{\prime}$ lly. $7 \times 0 \frac{1}{2}$ inches. Lax and interrupted.

I 5. kalon, Lozve. Found near Athlone by the late Colonel A. S. H. Lowe. $8 \times 1 \frac{1}{2}$ inches. Crenate.

16. lineare, O'Kelly. $2 \frac{1}{2} \times 0 \frac{1}{2}$ inches. A narrow form and depauperate.

17. lineare-major, O'Kelly. $9 \times 0 \frac{3}{4}$ inches. Very lax, stipes long. 18. majus, O'Kelly. $9 \frac{1}{2} \times 1 \frac{1}{1}$ inches. Flat.

19. minimum, Lorve. Devon. 2 inches long.

20. multifido-cristatum, O'Kelly. $4 \times 0_{\frac{6}{10}}^{\frac{6}{0}}$ inches. Multifidly crested.

21. ramoso-cristatum, Lozve. Found in Co. Clare, by Mr. A. IVise. $5 \frac{1}{2} \times 0 \frac{3}{4}$ inches.

22. ramosum, O'Kelly. $6 \times 0 \frac{7}{10}$ inches. Also Arnside, by Mr. J. Crossfield. Branching in the rachis.

23. subpinnatum, O'Kelly.

24. superbum, O' Kelly. $9 \times 1$ inches. A fine deeply crenate form. 25. tenuifolium, $O$ 'Kelly. $5 \frac{1}{2} \times 0_{\frac{3}{8}}^{3}$ inches. Slender.

26. truncatum, O'Kelly. $2 \frac{3}{4} \times 0_{\frac{1}{2}}^{\frac{1}{2}}$ inches. Depauperate and truncate.

27. variabile, Lowe. Found at Browsholme Hall, Clitheroe, by myself. 5 inches. And also in the Burren by Mr. O'felly; the latter has a more bushy habit.

\section{Tribe 9. SCOLOPENDRIEAE.}

\section{THE HART'S TONGUE FERN.}

\section{SCOLOPENDRIUM VULGARE.-Smith.}

No one can mistake the Hart's Tongue; for in its normal state, its strap-shaped, entire tongue-like deep green fronds are quite distinct in appearance. Although a widely distributed fern, it is only locally common, and occurs only to the height of about 600 feet, luxuriating most in shady, moist situations where the water drains off; damp walls, mouths of wells, and banks in shady lanes, are its special delight. It is not found north of the island of Gothland, in the Baltic Sea.

An evergreen species, with fronds from four to twenty-four inches in length. Although the Hart's Tongue has a single undivided frond, its prolific varieties assume the most remarkable peculiarities, so much so as to make it requisite to subdivide the varieties, and this has been done in the following manner :-

branched.
unequally branched
crested
conglomerated
sagittate
truncate
pouch-bearing
flexuose

plumose (crispum)
undulate
narrowed
muricate
supralineate
marginate
margin-altered
variegated.

Readily grown under cultivation, but liable to be attacked by the 
grub of the Weevil (Curculio sulcatus), which destroys the roots and eats into the centre of the stem. Although this grub occasionally attacks the Lady Fern and the Aspidium angulare, it is far more destructive to the Hart's Tongue.

\section{Division A.}

\section{ALTERATION IN SKELETON.}

\section{Group I. Ramose. (Branched.)}

Section a. RAMOSUM. (Stipes branched.)

* I areston, Lowe. Raised by myself. $10 \times 0 \frac{1}{2}$ inches; branclies tivisting and crossing each other; divisions finely cut. Head, 6 inches across.

2. cristatum, Lowe (ramo-cristatum, Clapham). Raised by the late Mr. Clapham. Width across the finger-crested divisions, 7 inches. Stipes, 4 inches. Length of whole frond, 7 inches.

*3. dichotomum, Lozve. Raised by myself. $14 \times 03$ inches. Branching from the base, again below the rachis, and again 4 inches below the apex, into many narrow divisions. Outline irregular; crests, 7 inches wide.

4. digitatum, Wollaston. Raised from spores by Mr. Wollaston; branched into a flat crest. In $1860 \mathrm{Mr}$. Crossficld found a form of this at Cork; and one has been raised by mysclf $9 \times 09$ inches with a digitate head $4 \frac{1}{2}$ inches across.

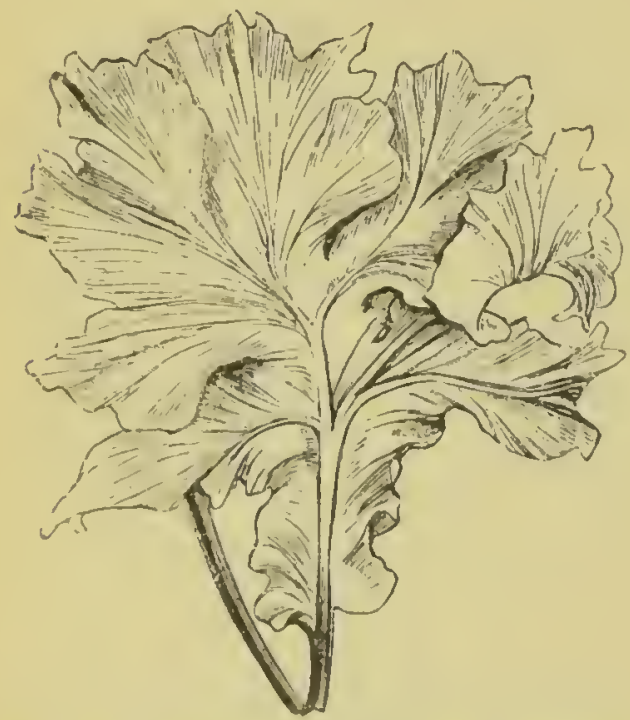

Fig. 28.-Scolopendrium vulgare, var. Edwardsii (ramose cresting).

5. Edwardsii, Loree. Found in Devon by Mr. Edwards ; branching from the base and again on the stipes, and repcating this on the rachis; bunch crested.

6. majus, Lowe (ramosum-major, Clapham). Found in Yorkshire in 1857 , by the latc $\mathrm{Mr}$. Clapham, $15 \times 2$ inches. Stipes and rachis splitting and producing two or more normal fronds.

7. Moly i, Lorie' (ramocristatum Moly, Wollestont). Found in 1862 in S. 1)eron by $\mathrm{Mr}$. Mloly. $12 \times 1 \frac{1}{2}$ inches. Irranching into five normal fronds will crested heads, 4 and 5 inches across.

8. ranosum, Willdenote (diedaleum, Deakin). A ramoscly crested form, known for many years. 


\section{Sub-section. RAMO-INEQUALE. (Unequally branched.)}

I. admirabile, Lowe. Raised by myself. $12 \times \mathrm{O}_{\frac{2}{8}}^{2}$ inches. Branching, and crested with narrow divisions; margin regularly dentate.

*2. Alexandrie, Lorve. Raised by the late Colonel Jones from Victoria, and more ramose than that variety. Length, I I inches ; width across the ramose head, 6 inches. Rachis linear and dentate.

3. arbusculare, Lorve. Raised by myself. Length, 9 inches, and width across the head, 7 inches; stem naked; palmate.

4. Atkinsoni, Lowe (inæequale furcans Atkinson, Wollaston). Raised in 1876 by Mr. C. J. Atkinson. Length, It inches; width across the branches, 10 inches. A very pleasing form.

5. blandum, Lowe. A ramose form raised by myself.

6. capitatum, Lowe (inaquale capitatum, Lowe). Raised by myself. I $8 \times 1$ inches. Margin deeply and variously cut; the capitate part also much cut ; the crest 5 inches wide. A bold fern with a straggling stag's-horn-like crest.

7. concavum, Loze (concavo-ramosum, Clapham). Raised by the late Mr. Clapham. Length, 7 inches, leafy portion only. 2 inches. Stipes branching at base into 5 or 6 fronds that are concave ; margin irregular ; rachis also branching and crested.

8. conjungendum, Lowe. Found in Devon by the Rev. F. Mules. $13 \times 1$ inches. Twin-fronded, strap-shaped and multifid; the divisions angular and pointed.

9. constellatum, Lorve. Raised by Mr. Glave. A dwarf, stembranching form; depauperate below the numerous bunch crests; length, 6 inches.

Io. cristatum, Lowe (ramo-cristatum, Wollaston). Found in S. Devon in 1862 , by Mr. Moly. Length, Io inches. An interesting ramose, crested form.

1 I. Delesserioides, Lowe. Raised by myself. $18 \times 0 \frac{1}{2}$ inches. Stipes branching and rebranching, not unlike the red seaweed. Delesseria sinuosa, Lamour; is a very singular variety.

* 12. Elworthii, Lowe (inaequale-furcans Elworthy, Wollaston). Raised in 1873 by the late Mr. Elworthy. Length, 9 inches; width across the branching head, 9 inches.

*I3. formosum, Lorve. Raised by myself. I4 $\times 0 \frac{3}{4}$ inches. Branching, margin irregular; the branches twisting across each other; the tips laciniately crested.

*I4. gloriosum, Lorve. Raised by myself. $22 \times 1 \frac{1}{4}$ inches. Irregular outline, as if bitten in places. Branching most on one side. Stipes, 7 inches; head 7 inches across.

15. keratoides, Lowe (inxquale cristatum, fones). Raised by the late Mr. Clapham. $9 \times 0 \frac{1}{5}$ inches. Branching and rebranching into a head 4 inches across. All parts of the frond narrow and irregularly lacerate; very stag's-horn-like.

I6. laudabile, Lowe. Raised by myself. $15 \times 1$ inches. Branching in the stipes, and having a crest 6 inches across, composed of broad divisions. Margin irregular.

${ }^{*}$ 17. mirabile, Low'e. Raised by myself. $7 \times$ I inches. Widening 
from the base, and dividing into branches on one side; terminating in a large crest.

18. mirificum, Lowe. Found by myself in I869, at IVestward Ho. $16 \times 0 \frac{7}{8}$ inches. Branching and rebranching; the topmost branches long, narrow, and stag's-horn-like. Width across the head, 4 inches. Margin, irregularly dentate.

19. multipinnatum, Moore (inaequale cristatum, Wollaston).

*20. notabile, Lowe. Raised by myself. $12 \times 0 \frac{1}{2}$ inches. A narrow dentate, Victoria-like variety; branching in stipes and rachis; the head not so spreading and divisions narrower. Stipes only 2 inclies.

*21. Ouranion, Lowe. Raised by myselt. I $5 \times 0 \frac{3}{4}$ inches, the margin very regularly cut into divisions; the capitate head like a bird's wings.

22. patulum, Lowe. Found at Littleham, by the late Rev. C. Padley. A large ramose form; rachis dividing in the middle and branching in a ramose manner.

23. ramo-congregatum, Birkenhead. Length, I foot.

24. ramo-cristatum, Clapham. Raised by Mr. Clapham, Mr. Moly, and Mr. Foster. Branched in stipes; and ends of branches crested.

25. ramo-digitatum, Bolton. Found in 1863 at Warton Crag by Mr. Bolton. Large, strong-growing, ramose, and slightly undulatc. form.

26. ramosissinum, Lozee. Raised by myself. A much branched

27. scrrula, Lowe. A very interesting seedling from Todmorden. Length, 6 inches. Branching, cresting, and the margins toothed like a saw.

*28. summum, Lowe. Raised by myself. $9 \times 0 \frac{1}{2}$ inches. Branching; the margins depauperate and irregularly toothed ; terminating in a crest 4 inches across.

29. Trevellyanæ, Lowe. Found near Nettlecombe by the late Mr. Elworthy. Stem nearly naked; erect. Width across the crested head, 4 inches; finely cut, interesting variety. Distinct, much branched and crested; leafy part linear. $12 \times 01$ inches. Stipes, 7 inches; a Victoria-like form.

30. variabile, Lowe (ramo-variabile, Wollasfon). Found in Dorset in 1875 , by the late Colonel Jones. $8 \times 13$ inches. Branching in stipes, and again in rachis into twin truncite fronds.

*31. Veloisii, Moore. A fine crested form introduced by Messrs. Veitch.

32. Victoria, Lowe. Raised by myself. $9 \times 0_{0}^{3}$ inches. Branching in stipes and rachis, into very narrow divisions. A pretty forn.

33. Whitwellii, Moore. Found in $1 \$ 73$ at liendal, by Mr. G. Whitwell. A fine robust form, strongly ramo-crested.

\section{Section $\beta$. CRISTATUMI. (Tasselled.)}

I. alatum, Lore (alatum-cristatum Mfoorc). Ratised at Pontefract, about 1884 by Messrs. Stansficld.

*2. allokoton, Lurve. Raised by myself (an inacqualc-furcans). 
$17 \times 0 \frac{7}{8}$ inches. Branches opposite each other, lower pair stipate; jori on margin. Head I I inches across.

3. Atkinsoni, Lorve (capitatum Atkinson, Stansfield). A neat lwarf crested variety found by a gardener (Atkinson) of Dalton in Furness, and sent to Messrs. Stansfield about I874.

4. attenuatum, Lowe (attenuato-cristatum Stewardson, Wollas'on). Raised in 1877 by Mr. Stewardson. Io $1 \frac{3}{4}$ inches in widest Jart. Narrowing from the base to the crested apex; the cresting ax. An interesting form.

*5. Babingtoni, Lorve. Raised by myself. $12 \times 1$ inches. Digiately and densely crisp-crested head, 6 inches across.

*6. Cliftii, Lowe. Found in North Wales by the late Mr. Clift. $12 \times 1$. A compact multifid very leafy crown with uncut margins.

7. columna, Lonve. Raised at St. Pierre, in $1885.10 \times 1 \frac{1}{4}$ inches. Normal, but ending abruptly $2 \frac{1}{2}$ inches below the apex, where it oranches into an erect crest $2 \frac{1}{2}$ inches across. Very column-like.

8. commixtum, Lowee. Raised by myself. A form of Cliftii with 1 greater crest.

9. contractum, Wollaston. Found in $\mathbf{I} 86 \mathbf{1}$, at Heversham Head, sy Mr. J. M. Barnes. A pretty variety; fronds contracted below he crest.

I0. coronatum, Stansfield. II $+\mathrm{O}_{4}^{\frac{3}{4}}$, a long strap-shaped form; he costa splitting 2 inches from the apex; the frond ending in a lobular crown-like head. Found in 1872 by the late Mr. A. Stansield.

II. curymbiferum, Lowe. Raised by myself. Length 6 inches. A oliose corymbose form.

12. cristagalli, Wollaston. Found in North Devon in I 864 by Mr. R. Moule. I $2 \times 1 \frac{1}{2}$ inches. Normal, with a symmetrical finelylivided crest. Found also in the Lake district; and at Drogheda y Mr. W. H. Phillips.

13. cristatum, Moore. A not uncommon form; fronds crested.

14. cristulatum, Stansfield. Raised by Messrs. Stansfield about 11874. A round crest of $1 \frac{1}{2}$ inches wide.

15. digitale, Lowe. A digitate form raised by myself.

I6. flibellatum, Moore. Found near Nettlecombe by the late Mr. Elworthy, $8 \times 1 \frac{1}{2}$, flabellately multifid.

17. flabellatum-Boltoni. Bames. Found in 1870 , near Kellet, by Mr. IV. Bolton. A fine form ; fronds short; head fan-shaped.

18. Fosteri, Lorve (medicaule capitatum, Jones). A most ineresting variety, raised by Mr. Foster of Salford in 1876. Stipes ranching at the base; a naked stem, except the reniform close apitate head ( $2 \frac{3}{4}$ inches across).

19. grandiceps, Jones. Found by Mr. John Cousins. Length, I I nches, width across the crest, I I inches. The grandest of Crested Hart's Tongues.

20. Hendersoni, Willison. Found in 1866 , near Whitby, by Mr. J. Henderson. Like a dwarf ramo-digitatum. Length, 6 inches. jtipes branching and re-branching into divisions ( 5 or 6 in numver) that branch and crest at the apex. 
21. lato-digitatum, Stansfeld. Raised by Messrs. Stansfield. $8 \times 1 \frac{3}{4}$. Costa branching into a wide digitate crest 6 inches across.

22. Malcomsonx, Stansfield. Found at Clonmel by Miss Malcomson. Length 13 inches. Margin irregular; branching and crested.

23. Millettii, Lowe (cristatum Millett, Wollaston). Found in North Devon in 1865 by Mr. Nillett. $14 \times 1 \frac{1}{3}$ inches; having a crested head 6 inches across.

24. multifidum, Gray. A not uncommon crested form.

25. mutandum, Lovee. In Colonel Jones's collection of living plants. History unknown. Length 10 inches. Normal for 5 inches, then branching and contracting to very narrow, whip-like branches, the tips bunch-crested; some of the heads being 5 inches across.

26. ornandum, Loze. Raised by myself. $14 \times 1$ inches. Crested digitately; has a slight tendency to be muricate.

27. ponderosum, Lozve (ponderoso-cristatum, Lowe). Raised by myself. Stem naked. Length 6 inches; crest 4 inches across. A conglomerate form.

28. ramo-cristulatum, Stansfielt. Raised by Messrs. Stansfield about 1886 . A very ramose cristulatum.

29. Riallii, Lowe (cristatum Riall, Jones). Found by the late Dr. Ryall. A neat, dwarf-crested variety.

30. Stewardsoni, Lowe (capitatum, Stcunardson). Found in IS72, at Dalton, by Mr. Stewardson. Fronds short; densely crested, crests large.

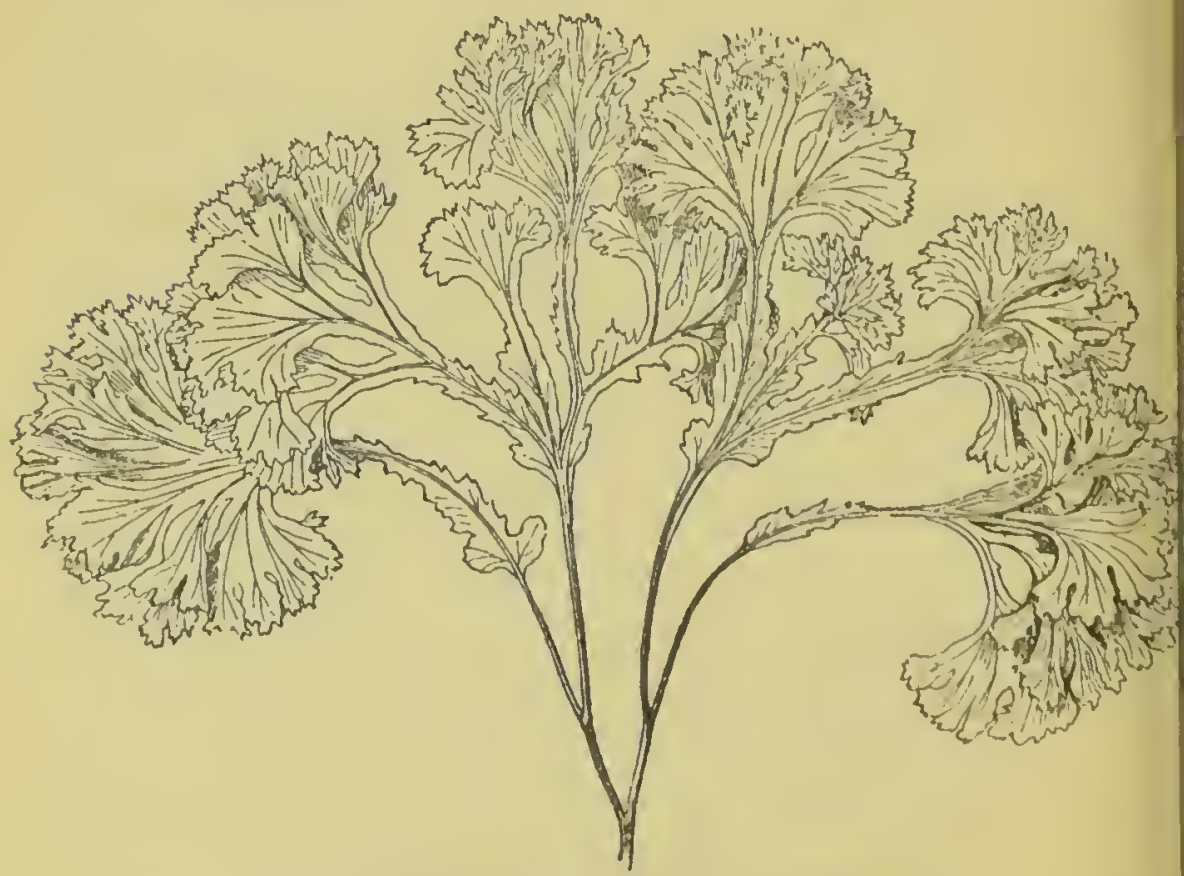

Fic. 29. -Scologendrium sulrite, uar, coustcilıtum. 
31. Studdartii, Lorve (capitatum Studdart, Jones). Found about IS8O, in Ireland, by Major C. F. Studdart. A fine crested form.

Sub-section. RAMO-MARGINATUM. (Marginal branched.)

1. acrocladon, Lowe (not of Clapham). Found in 1857 , at Ambleside, by myself. $12 \times 1 \frac{1}{2}$ inches. Normal, except a widespreading, finger-like multifid head.

2. alato-cristatum, Stansfield (not of Moore).

3. capitatum, Jones. Found by Mr. Foster. A densely crested, infra-lineate variety.

4. cervi comu, Stansfield (not of Moore). Fronds linear, branched and crested; segments very narrow. Length, 5 inches, Head $3 \frac{1}{2}$ inches across. Pretty.

5. chelaefrons-majus, Wollaston. Found in I86I, at Farleton Knot, by Mr. J. M. Barnes. Apex of frond like crab's claws; rather inconstant.

6. constellatum, Lozve. Raised by Mr. Glave. A dwarf, densely crested, very ramose form. Leafy part almost absent, except at the crests. Length 6 inches.

7. coronarium, Lowe. Raised by myself. Length 9 inches. Crenate, wavy; frond widest in the centre, contracting to the finelycut crown, and then 4 inches across.

8. distortum, Moore. Raised by Mr. Elworthy. Stipes and rachis bent; outline irregular; branching several times, but only dilate at the apex.

9. divaricatum, Moore. Found in Westmoreland by Mr. J. (Crossfield. Dividing near the apex into two branches, which spread at a wide angle; and these fork again in the same manner.

Io. Dunkeldense, Lowe. Found by myself at Dunkeld. $6 \times 2$ inches. Very irregular, having a branching stipitate lobe in the :middle of the stipes $2 \frac{1}{2}$ inches long. Very curious. Deeply incised; and apex flat owing to the costa dividing.

I I. Glavei, Lowe. Raised by Mr. Glave. Length 6 inches. Branching and re-branching from a naked stipes into almost leafless narruw divisions.

I2. inxquale-cristatum, Glave (multipinnatum, Clapham). 'Raised in 1876 by Mr. C. Glave. Length 12 inches. Branching and re-branching into a frond of finely-cut divisions 9 inches wide.

13. kephaloton, Lowe. Found in Devon by myself. $9 \times$ I inches. Margin irregular. Costa branching into a leafy laciniate head 6 inches across.

I4. multifido-nanum, Lorve. Found in Devon by Mr. W. Edwards. Stem naked; branching. Rachis also branching into a corymbose head. Dwarf.

I5. multifido-varians, Jones. Found in Devon in 1870 by Mrs. Grant. $20 \times 3 \frac{1}{4}$ inches. A noble grandly multifid form, sometimes I I inches across the broad foliose head.

16. nudistipes-cristatum, Mapplebeck. Raised in I871 by Mr. 'Mapplebeck. Length 9 inches. A long naked stem with a finely- 
cut circular crest. Colonel Jones considered that it suggested "seaweed."

*17. pericalles, Lowe. Raised by myself. I $4 \times 03$. Branching in both stipes and rachis, and forming a branching head 5 inches across. Margin irregular, in the manner of polyschides.

18. polycuspis-transversum, Moore. Found in 1861 at Brigsteer by Mr. J. M. Barnes. Remarkable for the crests crossing each other.

19. polycuspis-undosum, Moore. Found at Giggleswick Scars by Mr. Stanstield, near Doncaster by Mr. S. Appleby, and at Heversham Head by Mr. J. M. Barnes. A many-pointed twisted crest. A form of polycuspis has been found at Fermanagh by Mr. IV. H. Phillips.

20. ramo-marginatum, Clapinam. Raised in 1860 by the late Mr. Clapham. Length 14 inches. Branching on stipes and rachis, and terminating in several large crests. A lovely form.

2 I. ramo-palmatum, Clapham. Raised by the late Mr. Clapham. Length 3 inches; almost naked; twin-fronded. A lacerated handlike crest.

22. ramo-proliferum, Clapham. Raised by Mr. Clapham. Stipes and rachis branched. Length 3 inclies. Coarsely serrated, and apex split.

23. Shirenewtonense, Lozue. Found in 1888 on a wall in the grounds at Shirenewton by Mr. lreland. Naked stems. Length 5 inches. Digitately branched ; dividing into three leafy fronds, each dividing into two digitate crests; the tips flat and dentate; margin coarsely dentate; partly suprasoriferous. A very interesting dwarf form.

*24. tortuoso-cristatum, Lowe. Raised by inyself. $14 \times 2$ inches. Normal below the crestings. Tortuose crestings of large size (7 inches across), springing out of the leafy part of the frond. Haif a dozen fronds forming a bush 12 inches across.

25. unguiceps, Wollaston. Raised in I $\$ 70$ by Mr. E. F. Fox. $9 \times 0 \frac{1}{4}$ inches. A narrow variety with a bird's-claw-like crest. Sori on the margin.

26. unilaterale-ramosum, Lowe. Found at Sidmouth by Mirs. Thompson. Only branching on one side.

Section $\gamma$. CONGLOMERATUM. (Conglomerately branched.)

I. Baxteri, Moore. A copy of Coolingii.

2. conglomeratum, Lowe. Found at Truro by Mr. Dadds. Less leafy; the apices more lacerate, and more depauperate thin glomeratum.

3. congregatum, Lozve. Raised by myself. Stipes branching; and costa in leafy part splitting into branches that are denscly crested.

4. constellatum, Lowe. Raised by Mr. Glave of Scarborough.

5. Coolingii, Lowe. History unknown. Distributed by Mr. Edwin Cooling. A proliferous conglomerate fern. Length, $3 \pm$ inches. Formingr a ball-like bush, and each fiond like a bail. 
6. coronans, Moule. Unknown to me.

7. coronare, Lowe. Raised by myself. Length, 7 inches. Branching several times in stipes, and also in rachis, forming a dense, crested ball $5 \frac{1}{2}$ inches wide. Soriferous.

8. Cousensii, Jones. I have never seen this.

*9. densum, Lowe (conglomeratum-densum Kelway, Jones). Raised by Mr. Kelway. Length, 3 inches. A close, ball-like plant, the frond branching and cut up into numerous threads, producing plants at their tips. A marvellous form.

10. Drueryi, Lowe. Found at Sidford in 1888; robust and normal for 2 feet; then expanding into a corymb, which is divided into a moss-like ball.

I1. Elworthii, Moore. Raised by the late Mr. C. Elworthy. Length, only 2 inches. A singular ramose-flabellate form.

* 12. eulophion, Lowe. Raised by myself. Branching in the stipes. Erect heavy crest, curling inwards, and 7 inches wide. Length of frond, 8 inches.

I3. Fittii, Lowe (grandiceps Fitt, Jones). Raised by Mr. Fitt. Length, 6 inches. A curious dwarf grandiceps; spreading round the crown. Singular and unfern-like.

14. glomeratum, Moore. Found in Jersey by M. Piquet. Length, 6 inches. A globular crispy mass. Miss Nicholson found a form of this at Storth in 1867.

* 15. Gloveri, Stansfield. Raised by the late Mr. Glover. Length, 4 inches. A leafy conglomerate form, with rounded divisions.

16. Irelandii, Lowe. Found in the Aylstone, near Ross, by Mr. W. Ireland. Stems naked and very thick; much branched ; forming a rounded mass in the manner of Wardii, but having a fimbriated margin. Length, 6 inches.

I7. Jacksoni, Lowe (glomeratum Jackson, Jones). Found by the late Mr. Jackson. Length, ro inches. A conglomerate form with normal-looking fronds rising out of the crest; head, 5 inches across.

*18. Kelwayi, Lowe. A large form of "densum." Found in Sonierset. Length, 5 inches. Conglomerate; a fine dwarf variety.

19. Morgani, Moore. Length, 6 inches. Fronds flexuose; partly digitate and partly bunch-crested. Stem naked to crest; head 4 inches across.

20. pseudo-Wardii, Lowe. Raised by Mr. Glave from bulbils of "Wardii." Length, 4 inches. Branching and rebranching, but the divisions normal-looking.

21. ramusculum, Lozee. Found in Devon by Mr. W. Edwards, somewhat undulate, with a small multifid crest.

22. Robinsoni, Rackhouse (conglomeratum Robinson, Stansfield $t$. Raised by Mr. W. R. Robinson. Distinct from Coolingii in being less cut on the edges.

23. sphænula, Lowe. Raised by myself. A densely branching foliose fern with rounded divisions. Length, $3 \frac{1}{2}$ inches; width across the head, 4 inches.

24. splenula, Lowe. Found in Somerset by the late Mr. 
Elworthy. Length, $3 \frac{1}{2}$ inches. Repeatedly branching into rounded foliose divisions. Bolder than "Gloveri."

25. sylvestre, Lowe. Raised by myself; but there is a very similar variety at Nettlecombe Court, said to have been found in Somerset by the late Mr. Elworthy. A dense globular-crested form, branching in the stipes. Length, 5 inches; width across the head, $4 \frac{1}{2}$ inches.

26. variabile, Lowe (glomerato-variabile, Monkman). Raised by Mr. Stansfield. Length, 16 inches (stipes, 6 inches). The glomerate head from 6 to 10 inches across. Like glomeratum, with a few normal branching divisions.

27. Wardii, Clapham. Raised by Mr. Glave in a IVardian case. Length, 6 inches. Branches irregular. Margin copiously viviparous.

\section{Section $\delta$. SAGITTATUM. (Arrow-like projections.)}

I. acanthodes, Lozee. Found in Devon by Mr. Edwards. Resembles "cristatum," but with a larger crest and less sagittate lobes.

2. capitatum, Lozve (capitatum-projectum, Jones). $22 \times 6$ inches (in widest part). Sagittate; branching along the upper portion of the frond into heads 6 inches across.

3. Colmeri, Lowe (Sagittato-crispum, Wills). Found in Dorset, in 1875 , by Mr. M. Colmer. $17 \times 1 \frac{3}{4}$ inches. Somewhat resembling "Drummondx," but having a sagittate base.

4. conglobatum, Lowe. Found at St. Pierre in I 887 , by Mr. H. Bull. $4 \times 2$ inches. Projecting; deeply cut and multifid; sagittate lobes placed at right angles; forming a ball-like plant, hence the name.

5. cristatum, Lowe (Sagittato-cristatum, Clapham). Found near Scarborough by the late Mr. A. Clapham. I I $\times 3$ inches. Sagittate and crested. One found in Devon in 1859 by Mr. Hillman is more sagittate and has a crest 9 inches wide.

6. foliosum, Lowe. Raised by myself. $14 \times 2 \frac{1}{2}$ inches. Very foliose, and broadly sagittate; the head 7 inches across.

7. Hankeyi, Lowe (Sagittato-cristatum Hankey, Hollaston). A splendid variety, raised by Mr. W. Barnard Hankey. $16 \times 3$ inches. A crested sagittate form, 7 inches wicle at the sagittate base, and 7 inclies across the large sagittate head.

8. hastatum, James. Found in Guernsey, in 1860 , by the late Mr. James. $7 \times 0 \frac{7}{5}$ inches. A dwarf, normal, sagittate variety, with a crenate margin.

*9. hemionitoides, Moore (Sagittato-cristatum, Dadils). $M \mathrm{I}_{1}$. Dadds' plant (which is a copy of "liemionitoicles," raised by Messrs. Stansfield,) was found in North Devon, in 1860, by Mr. J. 1)adds. Length, 9 inches; width of sagittate base, $4 \frac{1}{2}$ inches. Apex and lobes crested.

* Io. Hookeri, Lorve. Raised by myself. $16 \times 5 \frac{1}{2}$ inclies. I)iffers in the projections commencing on the sagritate base. Fronds broad. Colour, very bright green. 
I I. Jamesii, Lowe. Raised by the late Mr. James. Slightly crisp; conspicuously sagittate at the base, and having a leafy stag's-horn-like cresting at the apex. Sori like a row of beads on the upper surface.

12. laceratum, Moore (endivifolium, Wollaston). Found in I $85 \mathrm{I}$, in Somerset, by the late Mr. J. Young. Length, I I inches; width across the sagittate base, 7 inches; capitate head often 7 inches across. Mr. Glave raised a very fine form. Mr. W. H. Phillips also found a plant at Strabane.

I3. lacertum, Willison. Found near Whitby by Mr. W. Willison, and called by him "The Lizard," from the apex of the frond resembling a lizard's tail, and the lobes the paddles of this reptile.

14. Molyi, Lowe (Sagittatum projectum Moly, Wollaston). Found in 1862 , in Dorset, by Mr. James Moly. "19×4 inches (in widest part), projections more numerous than in "Sclateri."

I 5. multifidum, Lowe (Sagittato-multifidum, Jones). Raised in 1873 by the late Colonel Jones. $13 \times 7$ inches. Leafy portion of frond somewhat triangular.

16. nudisorum, Lorve (Sagittato-nudisorum, Barnes). Found in I863, at Slack Head. by Mr. J. M. Barnes. Very large auricles. Sori without indusium.

17. palmatum, Lorve (palmato-marginatum, Willison). Raised by Mr. Willison. $2 \frac{1}{2} \times 2$ inches. Triangular; blunt apex.

*I8. princeps, Lozve. A very broad, distinct form. Raised by myself.

19. projectum, Wollaston. Raised in 1876 by Mr. J. Moly. Io $\times 3 \frac{1}{2}$ inches (in widest part). A remarkable and very ragged variety.

20. sagittatum, Moly. Found in Somerset, in 1876 , by Mr. J. Moly. I $4 \times 1 \frac{1}{4}$ inches. Normal; with a sagittate base, where 4 inches wide. It was also found at Force by Dr. Allchin.

2 I. Sclateri, Lowe (Sagittato-projectum Sclater, Wollaston). Found in Sligo, in 1860 , by Captain Sclater. $23 \times 5$ inches (in widest part). A grand crested "projectum."

22. Snellii, Lowe (Sagittato-cristatum, Snell, Jones. In the way of hemionitoides; slightly marginate.

23. Welmani, Lowe (Sagittato-cristatum Welman, Jones). Found in Dorset, in 1873 , by Mr. Welman. $16 \times 2$ inches. Hastate, and crested.

24. Westroppii, Loree (Sagittato-projectum Westropp, Stansfield). $24 \times 3$ inches. A very large and fine variety found in one of the islands of Arran, Co. Clare, by Mr. Westropp.

25. Wollastoni, Lowe (Sagittato-crispum, Monre). Found at Petersfield and Ottery St. Mary by Mr. G. B. Wollaston; and Barnstaple, by the late Mr. Jackson. I $_{3} \times 3$ inches. Sagittate and crisp.

26. viviparum, Lowe (cristato viviparum O'Kelly, Jones). Found in County Clare by Mr. O'Kelly. I $2 \times 1 \frac{1}{4}$ inches (stipes, 6 nches). Basal lobes leathery ; compactly crested. The leafy porion growing bulbils on all parts. Very distinct. 


\section{Group II. Truncate.}

Section a. TRUNCATUM. (Ending abruptly.)

I. accisum, Lowe. Found in Devon; and recently at Carron, by Mr. P. B. O'Kelly. $12 \times 1 \frac{1}{2}$ inches. Normal, except at the apex, which terminates in a leafy frill within the frond.

2. constrictum, Hoore. Found in Guemsey by the late Mr. James. $6 \times 1 \frac{1}{2}$ inches. Depauperate; and naked to stem in centre. Very irregular, laciniate, and slightly marginate.

3. corniculatum, Lowe. From the late Colonel Jones's collection. $S \times 1$ inches. Truncate, cornute, rugose (except a broad that rachis); the rugose margin $\frac{1}{4}$-inch thick. Stipes, $4 \frac{1}{2}$ inches.

4. cornutum, Lowe (truncato-cornutum, Mapplibeck). Raised in IS72 by MI. Mapplebeck. $9 \frac{1}{2} \times 2 \frac{1}{2}$ inches. Frond terminating in a horn $1 \frac{1}{4}$ inches long. No pouch. Found also in the Lake district by Mrs. Hodgson and Mr. J. Crossfield. One raised by myself is $6 \times 2$ inches; with wavy margin.

5. obtuso-dentatum, Moore. Found in 1855, near llfracombe, by Rev. J. M. Chanter. $12 \times 1_{4}^{\frac{1}{4}}$ inches. Apex blunt, miryin having uniform dentate crenatures.

6. O'Kellyi, Lowe (truncatum, O'Kelly). Found at Blackhead by Mr. O'Kelly, where he alsc found another small rotund form.

7. reniforme, Williams. Found in several localities. $4 \times 2$ inches. Abrupt and kidney-shaped. Mrs. Grant has the best form.

8. significans, Lowe. Raised by myself. $5 \times 1 \frac{1}{2}$ inches. Rugose and truncate.

9. subcornutum, Tait. $8 \times \mathrm{I}$ inches. Rigid. Crenate; apex abruptly rounded. Cornute.

Io. supra-cornutum, Lowe. Horned above.

I r. truncatun, Ivery. Not uncommon. A nice form has been found at Black Head, Co. Clare, by Mr. P. B. O'Kelly.

\section{Sub-section. PERAFERENS. (Bearing a pouch.)}

I. acetabulum, Lowe. Raised by myself. $A$ shallow cup at apex, and there supralineate. $12 \times 23$ inches (of which 7 is the stipes).

2. anomalum, Lowe (perafero-anomalum, Mapplebeck). Raised by Mr. Mapplebeck in IS72. $8 \times 13$ inches; stipes 4 inches long. Pouch muricate, but frond smooth.

3. crispissimum, Lowe. Raised by myself. Wavy in a crispumlike manner.

4. excurrens, Moore. Found in I 864 , at Whitbarrow; by MI. G. Stabler. Hoined on the upper side.

5. fimbriatum, Lonoe (niarked 102 in the late Colonel Jones's collection). $6 \times 1 \frac{1}{2}$ inches. The edges of the cup fringed; cornute. MIr. IV. H. l'hillips found a similar form at Gormanstown.

6. incurvare, Lowe. Ratised by myself. 10 $\times 1$ inches. Costa dividins 2 inches from the apex, forming an imperfect pouch at the top, which faces the front of the frond. There are two lorms at the base on the underside bearing sori. 
7. Jamesii, Lowe (perafero-muricatum James, No. I, Wollaston). Raised in 1870 by the late Mr. James. $8 \times 2$ inches. Crispum-like and cornute.

8. Jonesii, Lowe (peraferens Jones, Jones). Raised by the late Colonel Jones. $9 \times 2 \frac{1}{2}$ inches. Some fronds smooth, others rough. Costa ending I inch below the tip, where a large horn is formed. Margin irregularly fimbriated. Pouch, 2 inches in length.

9. marginatum, Lowe. No history (marked 106 in the late Colonel Jones's collection). $8 \times 1 \frac{1}{4}$ inches. Submarginate ; fronds widest at the apex; peraferous and cornute.

*Io. mirandum, Lowe. Raised by myself. $9 \frac{1}{2} \times 2$ inches. Smooth and normal, the costa splitting near the apex, each half furnished with a horn; very large pouch, $2 \times 1$ inches.

II. muricatum, Lowe (peraferomuricatum James, No. 2, Wollaston). Raised by the late Mr. J. James. $8 \times \mathrm{I}_{4}^{\frac{1}{4}}$ inches. Cornute; texture thin; pouch confused.

12. peplum, Lowe. From the late Colonel Jones's collection. $6 \times 1 \frac{1}{4}$ inches. Rugose, with a sharp horn-like elongation above a rosette-like pouch.

I3. peraferens, Wollaston. Found in Ireland by Dr. Allchin, and at Ballygarth, by $\mathrm{Mr}$. IV. H. Phillips. The type. $10 \times 2$ inches. Costa not reaching the margin, but developing a leafy pouch.

I4. poculum, Love. Rugose throughout. 'The apex of frond bending over, where a thorn an inch long rises out of a rosette pouch. Raised by myself. $9 \times 1 \frac{1}{2}$ inches.

* I 5. rosetta, Lowe. Raised by myself. $9 \times 2$ inches. A broad rugose form, ending in a horn half an inch long. The pouch, like a rosette (or double flower), and half an inch in width. Not rugose to the margin. Another seedling, $7 \times 1 \frac{1}{2}$ inches, is very similar, except having concave fronds.

16. rugosum, Allchin. Found in Ireland by Dr. Allchin. $8 \times 1 \frac{1}{2}$ inches. Leafy part only 3 to 4 inches. Apex irregular, rugose, and having an irregular pouch.

I7. sinum, Lowe (pocilliforme, Pactley). Found at Hawkchurch by Mr. Moly. $8 \times 1 \frac{3}{4}$ inches. Undulate, irregularly marginate, truncate; horned, and bearing a pouch (with a crisp margin); I $\frac{1}{2} \times 0 \frac{3}{4}$ inches. 
*18. Stella, Lowe. Raised by myself. $10 \times 1 \frac{3}{4}$ inches. Very papillose; rounded basal lobes extending beyond the general outline; a rosette pouch and cornute.

19. supraperaferens, Lowe. Raised by myself. $17 \times 1$ inches. Irregular ; very rugose, extending to the rachis; with a small pouch on the rachis (upper side), 5 inches below the apex. Rachis bending and tip of frond weeping. Sometimes cornute.

20. varians, O'Kelly. Found at Ballaganor, County Clare, by Mr. P. B. O'Kelly. $9 \times 2$ inches. The leafy portion only 3 inches long.

\section{Group III. Flexuose. (Bending.)}

\section{Section a. FLEXUOSUM. (Bending.)}

1. complicandum, Lowe. Raised by myself. $5 \times 1 \frac{1}{2}$ inches. A twisted, undulate, rugose and spiral form; near the apex the margins of the frond fold over and clasp each other.

2. flexuosum, Wollaston (cymbxforme, Wollaston). Found at Whitbarrow in $186 \mathrm{I}$ by Mr. J. M. Barnes. The best flexuose form. $14 \times 1 \frac{1}{4}$ inches. Miss F. Kitson found a flexuosum in South Devon, Mr. A. Lcipner another in Somerset, and Mr. G. Stabler one at Whitbarrow.

3. muricatum, Lowe (tortuoso-muricatum, Jones). Raised by myself. $15 \times 1 \frac{1}{2}$ inches. Rachis twisting, and costa on upper side ribbed.

4. spira, Lowe. An extraordinary combination of forms ; flexuous. Raised by myself.

5. torquere, Lowe. Raised by myself. $7 \times 1 \frac{1}{2}$ inches. Stipes and rachis flexuose, rugose, undulate, twisting, but not marginate. Rachis dividing 3 inches from apex, the divisions twisting round each other.

\section{Division $B$.}

\section{ALTERATION IN SOFT PARTS.}

\section{Group I. Increased Development.}

\section{Section a. CRISPUM. (Crispy.)}

*I. adornatum, Love (crispum-multifidum, Jones; and crispumgrandiceps, fones). Raised by myself in $1884.12 \times 3$ inches. A large capitate head ( $4 \frac{1}{2}$ inches wide). Sterile; well crisped.

2. amplum, Lozve. Found by Mis. Hole. I $8 \times 4$ inches. Deeply and densely frilled. Margin crenate; apex, multifid.

*3. angustum, Lore (crispo-angustum, Lorie). Found in Devon by the late Rev. C. Padley. $15 \times 12$ inches. Narrow, with naked stem of 6 inches.

4. Baldwyni, Lowe. Found in the Mountain Valley, near Chepstow, by, the late Mr. John Baldwyn. $16 \times 2 \frac{1}{3}$ inches. Well frilled. A marvellous form, one half of the fronds being conglomerate; these are 6 inches in length, and 5 inches across the conglomerate, dense, foliose crown. 1 am indebted to Mr. Edwin Ellis for this striking variety.

5. Bowdoni, Lone (crispum Bowdon, Jones). Found in the 
Lake district by Mr. Bowdon. I $4 \times 1 \frac{3}{4}$ inches. The sagittate lobes branching.

6. bulbiferum, Stansficld. Rather broader and less fringed than usual. Bulbiferous.

7. capitatum, Lowe (crispum-capitatum, Jones). The late Colonel Jones's collection. History unknown. $22 \times 3$ inches (of which the stipes is 6). A capitate head, 5 inches across.

8. capitulum, Lowe (crispum-cristatum, Clapham). History unknown (marked "Glave" in the late Colonel Jones's collection). $18 \times 2$ inches. A narrow, well-frilled variety. Small capitate head.

9. Claphami, Lowe (crispum Clapham, Wollaston). Found in 1857, in Yorkshire, by the coachman of the late Mr. Clapham. $18 \times 1 \frac{3}{t}$ inches. Base sagittate; projecting lobes fimbriate; apex crested. Fronds variable. A more recent seedling is densely crested.

10. convolvere, Lorve. Found by the late Rev. C. Padley. $14 \times 3$ inches. Lower half of frond irregular; rolling round; and the stem is naked for 2 inches above the round basal lobes.

I I. cornutum, Willison. Found in Yorkshire by Mr. Buckle. Broadest at base; margin cripsed and incised; apex pointed. Horned in centre of the frond.

12. Cowburni, Lowe (crispum Cowburn, Jones). Found in 1885 at Dennil Hill by Major Cowburn. $19 \times 4$ inches. A grand, flat, crisped form. Margin cut. Habit erect. Major Cowburn has found nineteen plants in this locality.

13. crispum, Grey. (The original type.) Elcgantly frilled. A number of distinct forms (all sterile) have been found in the Lake district. Mr. W. H. Phillips found it in Co. Tyrone.

14. cristatum, Lozere (crispum cristatum, Padley). Found in Devon by the late Rev. C. Padley. Apex divided into leafy crests. * I . Cropperi, Lowe (crispum fimbriatum Cropper, Stansfield). Raised by Mr. Cropper. Long, narrow, fimbriate, multifid fronds. Very promising.

I6. Curnowii, Lowe. Recently found near Penzance by Mr. Curnow. A multifid form.

17. Currei, Lozve. Found in 1870 at Itton Court by the late Mr. Pierce (gardener to Mr. W. E. C. Curre). A long and somewhat narrow form. $16 \times 2 \frac{1}{2}$ inches. Flatly crisped, and basal lobes rotund, folding over and hiding the stipes. Not unlike Grantæe in form, but not variegated.

18. densum, Sim. Broad and densely frilled. Apex much lacerated.

I9. Drummondæ, Moore (crispum Miss Drummond, Wollaston). Found near Falmouth by Miss M. Drummond. $22 \times 1 \frac{1}{2}$ inches. Frond narrowing upwards and terminating in a head 9 inches broad. In 1875 a variety with sagittate base, but with much smaller crest, was found in Dorset.

20. elegans, Lowe (crispum-elegans, Jones). Found near Tintern by Mr. Baldwyn. $12 \times 2 \frac{3}{4}$ inches. Widely, but well crisped. Very short stipes. 
21. excisum, Lowe. Found in I 888 at Dennil Hill by Major Cowburn. This variety only differs from "Cowburni" in being decply incised on the upper part of the frond; occasionally soriferous.

22. fertile, Lowe (crispum-fertile, Stansficld). Found in I863, at Grange, by MIr. E. G. Wrigley. $24 \times 1 \frac{1}{2}$ inches; width at base $I$ inch and in centre 2 inches. Well crisped and crenulated, and copiously soriferous.

23. fimbriato-fertile, Lowve (crispum fimbriato-fertile, Jones). A prominently but not densely crisp variety, with large round basal lobes and a narrow fimbriated margin. I $5 \times 2 \frac{1}{2}$ inches. Sparingly fertilc.

24. fimbriatum, Lotve (crispum fimbriatum Stansficld, Jones). Raised by Messrs. Stansticld, at Sale. A large fimbriate form, profusely frilled; the frills below overlapping from opposite sides and hiding the rachis. Fertile. $16 \times 2 \frac{1}{4}$ inches.

25. fissum, Lowe (crispo-fissum, Barnes). Found in 1877 at Milnthorpe by Mr. T. Airey. A small but beautiful narrow crispy form.

26. Fosteri, Lowe (Sagittato-crispum Foster, Jones). Found in I 876 in Ireland by Mr. Foster, of Manchester.

27. Foxii, Lowe (crispum fertile, Fox). Found in IS68, in Cornwall, by $\mathrm{Mr}$. Moule. $192 \times 3$ inches. Fronds densely fringed. The rounded sagittate lobes are occasionally very large. Fertile. A "crispum-fertile" was found in I $\$ 58$, and another in I 863 .

28. grande, Lowe (crispum grande Wills, Wollczston). Found by the late Mr. Wills. A very large, broad, beautifully frilled form, with an unusually long, naked stem.

29. grandidens, Lowe. Found in North Wales by the late Mr. Clift. Split quite to the rachis, and depauperate.

30. imbricatum, Lowe. A splendidly crisp form, frills quite wrapping over each other; known as the Roundstone variety. $9 \times 2 \frac{1}{1}$ inches.

31. irregulare, Lowe (crispum irregulare, Moore). Irregularly laciniate in parts of the frond, and there marginate.

32. Jacksoni, Loree (Sagittato-crispum Jackson, Woore). Found at Barnstaple by the late Mr. Jackson, and at Ottery St. Mary by Mr. G. B. Wollaston. $16 \times 2$ inches. Undulate and crenate and sagittate, combining Sagittatum and crispum.

33. Jonesii, Lowe (crispum capitatum, Jones). Raised in IS74 by the late Colonel Jones. $12 \times 23$ inches. A short, broad, fronded form, the capitate head 6 inches in diameter.

*34. Kitsona, Lowe (crispum-multifidum, Jones; crispum maximum, Gray). Found in Devon by Miss Fanny Kitson. $20 \times 23$ inches. Fincly crisped, crested apex. A very symmetrical variety.

35. latissimum, Lote (crispum-latissimmm, Jones). A wide form.

36. latum, Lowe (crispum-latum, Moore). Found neal liarnstaple by the late Mr. C. Jackson, and at Nettlecombe by the late Mr. Elworthy. $16 \times 4$ inches. Broad. Basal lobes separated from the rest of the frond. 
3\%. longipes, Lowe (crispum longipes, Jones). form. $17 \times 3$ inches. (The stipes 6 inches long.)

38. macandri, Lorve. A bold, handsome form. Raised by the late Colonel Jones, and given whilst young to Professor Morris, of Bath. The frillings are wider apart than usual. IS $\times 5$ inches.

39. majus, Lowe (crispum majus, Mloore). Found in Guernsey by the late Mr. Jackson. Length, I9 inches (of which the stipes is 7). Habit erect. Basal lobes large.

40. minus, Lowe (crispum minus, Jackson). Found by Mr. Jackson in Guernsey. IO X $1 \frac{1}{2}$ inches. Margin well frilled.

4!. Mosesii, Lowe (crispum majus Moses, Jones). A broad, symmetrical form found in the Lake district. $20 \times 4 \frac{1}{2}$ inches. A grand variety. The basal lobes overlapping the stipes.

42. Oakeleyi, Lowe. Found about I 876, at Llangarrow, Hereford, by the Rev. W. Bagnall Oakeley. II $\times 2$ inches. Sagittate lobes round; undulately crested. Sterile.

43. projectum, Lorve. A crispum found by Mr. H. Bull at St. Pierre, which is also sagittate, nuch cut, multifid, and well crisped. * 44. ramo-cristatum, Stansfield (crispum fimbriato-cristatum, Stansfield). A fimbriated form of great beauty. Raised by Messrs. Stansfield. Branching in the stipes and rachis, and crested.

*45. reflexum, Lozoc (crispum reflexum Wills, Jones). Found by the late Mr. Wills. Large; very broad, and long naked stems (7 inches long). Basal lobes very large. Frilling reflexed. $20 \times 5$ inches (at base, where broadest). Beautiful.

*46. Robinsoni, Lowe (crispum Robinson, Jones). Found in North Lancashire by Mr. Robinson. $20 \times 3 \frac{1}{2}$ inches. Crenate on the margin and exquisitely frilled.

* 47. robustum, Lowe (crispum robustum, Jones). Found near Shirenewton, Monmouthshire, in 1866 , by the late Colonel A. M. Jones. $23 \times 4 \frac{1}{2}$ inches. Stipes short. A grand variety, with curving fronds. Found also at Hawkchurch by Mr. Moly.

48. serratum, Lowe (crispum serratum, Jones). Found in I 866 near Shirenewton by the late Colonel Jones. $18 \times 3$ inches. Serrated. Stipes brief.

49. serratum-fertile, Lnove (crispum serratum-fertile, Jones). Found in Devon by Mr. Moule. A serrated, fertile form.

50. soriferum, Lowe (crispum soriferum, Barnes). Found in i 861 at Whitbarrow by Mr. A. B. Taylor. A thin, undulated, fertile variety.

51. St. Pierrense, Low'e. Found in I8So at St. Pierre hy Mr. H. Bull. I $7 \times 2 \frac{1}{2}$ inches. Widest at base; rounded sagit tate lobes; symmctrically frilled. Slightly soriferous.

52. Stableræ, Lowve (crispum Stablera, Jones). Distinct. Found in the Lake district by Mrs. Stabler. Large. Stipes very long : fronds pointed, broadest at the base. $17 \times 3$ inches.

53. Stansfieldii, Stansfield. Raised in 1872 by Messrs. Stansfield. $9 \times 1 \frac{1}{2}$ inches. It differs from the original "Stansfieldii" figured in "Our Native Ferns," in being crested and sagittate; sometimes the fronds are branched. 
54. uncinatum, Moore. Found in I863, in County Clare, by Mr. A. Stansfield. I I $\times 2$ inches. Apex rounded; costa crooked; and the basal lobes twisted in the way of a hook.

55. variabile, Lowe (crispum-variabile, Jones; and crispumdiversifrons, Jones). Raised in 1874 by the late Colonel Jones. $13 \times 4 \frac{1}{4}$ inches. Stipes, $4 \frac{1}{2}$ inches. Fronds broadest at the base. Occasionally normal, but sagittate ; fertile fronds, varying in width from 2 to $3 \frac{1}{2}$ inches.

*56. Willsii, Lowe (crispum Wills, Wollaston). Found in Somerset in 1870 by the late Mr. J. Wills. I $7 \times 4$ inches. Broad, long stalked, and beautifully crisped.

57. Wollastoni, Lowe (sagittato-crispum, Wollaston). Found in 1855 , in Hants, by Mr. G. B. Wollaston. $23 \times 3 \frac{1}{4}$ inches. Basal sagittate lobes, 4 to 5 inches wide. A grand form.

Note-There are scveral forms of Crispum that have been recently found near Chepstow, which are not yet fully enough developed to be included.

\section{Section $\beta$. UNDULATUM. (Wavy, but not crispy.)}

I. asperitate, Lowe. Raised by myself. $6 \times$ I inches. Very rough ; subspiral as well as undulate.

2. capitatum, Lowe. Raised by the late Colonel Jones. Length 9 inches. Dividing into two leafy branches, twisting into a capitate head.

3. cochleato-multifidum, Lowe. Raised by myself in $\mathrm{I} \$ 79$, differing from "cochleatum" in having a spirally coiled branching apex. $16 \times 2 \frac{1}{4}$ inches.

4. cochleatum, Lowe. Raised by myself in 1879. The apex turning spirally like a snail's shell; a well-marked undulate form.

5. contractum, Lozve. Found in Devon, by the late Mr. C. Jackson. Lower half undulate, above contracted and partially marginate.

6. cristatum, Lowe (undulato-cristatum, Stansficld). Raised by Messrs. Stansfield about I 877.

*7. daphnites, Lozve. Raised by myself. Rugose, undulate, but not marginate. $12 \times 1 \frac{1}{4}$ inches. Bold stiff fronds, widest in the centre.

8. extans, Lowe. Raised by myself. Base of the prominent parts rugose; prominences very stiff and half an inch lons. Spirally twisted; a distinct wavy form. $5 \times 1$ inclies.

9. Haburnense, Lorve. Found at Haburn Wyke by myself. $28 \times 3$ inches. Only slightly undulate. A giant form with a multifid tip.

Io. multifidum, l.owe (undulato-multifilum, I'allastun). Apex multifid, but scarcely wider than the frond. Found in IS62 at Witherslack by Mr. J. M. Barnes, also in l.ancashice in 1877 by Mr. Stewardson. Frilled as well as crested.

I I. prodigiosum, Lowe. Raised by myself $\delta \times 1$ inches. Undulate and depanperate. A twisted, crested apex, 3 inches wide. 
Segments narrow and frond-like, their margins conspicuously toothed.

*I2. ptereidon, Lowe. Raised by myself. Rugose. $12 \times 1 \frac{2}{2}$ inches. Very irregular ; round lobed ; upper half contracted.

13. ramosum, Lowe (undulato-ramosum, Lowe). Found in Devon by Mr. Moly. Undulate, with a large much-branched undulate apex.

14. reflexum, Lozve (undulato-reflexum, Jones). From the late Colonel Jones's collection. II $\times I \frac{1}{2}$ inches. Dark shiny green ; reflexed : slightly multifid.

15. rigidum, Lowe (undulato-rigidum, Jones). Found in Devon by Mr. Edwards. A large form.

I6. sinuato-multifidum, Padley. Found in North Devon by the late Rev. C. Padley. A fine undulate form with a twisting branched a pex.

17. spira, Lowe. Raised by myself. $5 \times 1 \frac{1}{2}$ inches. Spiral as well as undulate. Rachis, near summit, dividing and twisting.

I8. spirale, Moore. Found in Guernsey by the late Mr. J. James, and at Nailsworth by Mrs. Campbell, and at Heversham Head by Mr. J. M. Barnes. $5 \times 1$ inches. Basal half undulate ; above, spirally twisted.

19. Stansfieldii, Loze (undulato-cristatum, Stansfield).

30. subundulatum, Lowe. Raised by myself. $12 \times 1 \frac{1}{4}$ inches. Thick, deep green, shining fronds. Leafy part curling round the rachis at the base.

*21. synthesina, Lowe. Raised by myself. A cross between " undulatum," "spirale," "rugosum," and "keratoides," combining the characters of all these four varieties.

*22. tortum, Lowe. Raised by myself. A bold undulate form. $14 \times 1 \frac{1}{2}$ inches. Apex crested and twisted.

23. transverso-lobatum, Moore. Found at Nettlecombe by the late Mr. C. E. Elworthy, at Doncaster by Mr. S. Appleby, and at Castle Howard and Gordale Scars by Messrs. Stansfield. The multifid a pex has its branches crossing each other.

24. transverso-multifidum, Moore. Found near Ilfracombe by Mlr. Dadds. Having a compact, multifid, weeping apex.

25. undulatum, Moore (type). Found in many localities. $12 \times 1 \frac{1}{2}$ inches. Wavy, but not crispy. Thick and fertile.

26. undulosum, Wollaston. Found in 1862 , in Levens Park, by Mr. J. Garnett. A gored, undulate, and crested variety.

\section{Group II. Narrowing of Skeleton.}

Section a. LINEARE. (Narrowed.)

1. bulbiferum, Lowe (lineare, Wollaston). Found in 1861, at Whitbarrow, by Mr. J. M. Barnes. Very narrow, and bearing bulbs.

2. circinatum, Lozve. Raised by the late Mr. Clapham. $18 \times \mathrm{O}_{4}^{3}$ inches. Bidentate margin. Apex tasseled with small foliose segments ; and circinate.

3. coriaceo-cristatum, Lowe. Raised by the late Mr. Clapham. 
$9 \times 0 \frac{1}{2}$ inches. Deep green, thick, fleshy fronds; with a small, thick, erect crest.

4. crispatum, $O^{\prime} K^{\prime}$ elly. A curled form from the Burren.

*5. curiose, Lowe. Raised by myself. $8 \times 0 \frac{3}{8}$ inches. Like a very irregular "lonchophorum." Basal lobes, and here and there projections. Apex crested.

6. gymnosorum, Moore. Found at Minehead by Mr. W. Bowdon. A narrow form. Length 6 inches. Stipes densely hairscaly; veins and sori very oblique. Upper surface striate. Apex multitid.

* 7. involvens, Mapplebeck. Raised by Mr. J. E. Mapplebeck in I 87 L. Length 9 inches. Almost without leafy part. A few stalked depauperate segments. Apex turning round into a circle.

8. laciniato-crispum, Barnes. Found in IS65, at Warton Crag, by Mr. T. Bolton. Frond reduced in places. A fine variety.

9. laciniato-cristatum, Bames. Found in IS62 at Brackenthwaite by Mr. J. M. Barnes. Dwarf. Fronds reduced; and crested.

Io. laciniato-irregulare, Barnes. Found in I861, in Levens Park by Mr. J. M. Barnes. Irregularly reduced. Robust.

I I. laciniato-marginatum, barnes. Found in IS65, at Heversham Head, by Mr. J. M. Barnes. Fronds reduced and margined.

I2. laciniato-spirale, barnes. Found in 1865 , at Whitbarrow, by Mr. J. M. Barnes. Undulated and twisted.

I3. liciniatum, Wollaston. Narrow and irregular, cxcept near the apex, where normal. Not uncommon.

I 4. limbospermo-cristatum, Wollaston. Found in $18 ; 8$, in Somerset, by the late Mr. Elworthy. $16 \times 1 \frac{1}{2}$ inclies. Crest 3 inches across.

I5. limbospermum, Moore. Found near Nettlecombe by the late Mr. C. Elworthy ; and in IS60, on Beetham Fell, by Mr. J. Crossfietd. Outline slightly irrcgular. Sori on the margin. $10 \times 1 \frac{1}{2}$ inches.

I6. lineare, Jones. Raised in 1870 by the late Colonel A. M. Jones. $18.1 \times 01$ inches. Very long and narrow ; maryin toothed. Two basal lobes. I raised an almost identical form in I $\$ 67$, named "grammicon."

I7. lobato-densum, Wollaston. Found in I86I, in Levens Park, by Mr. J. M. Barnes. Thick and undulate.

I8. lobato-divergens, Barmes. Found in 1864, at Heversham, by Mr. J. M. Barnes. Lobes at right angles in form of a cross.

I9. Iobatum, Deakin. Common varicty, fronds forked.

20. lonchophorum, MFore. Found in North Lancashire, in 186z, by Mr. R. Preston, and in Baycliff Lanc, in 1870, by Mr. J.K. Hodgson. $9 \times 0.3$ inches. Strap-shaped; sori marginal.

2I. multifidum, Lowe (lineare multifidum, Jomes). Raised in I 874 by Mr. E. F. Eox. Stem naked and branching, terminatingr in elegant lix crests 3 inclies across. Length, 14 inclies.

22. polyschides, Rin. One of the carliest known forms. $12 \times 03$ inches. Irregularly crenate. 
23. polyschides-crispum, Lowe. Raised by the late Mr. Clapham. Length, Io inches. A crisped "polyschides."

24. rimosum, Moore. Found in Guernsey by the late Mr. James. I $8 \times 2$ inches. Crenate; near the divided apex profoundly incised. Upper surface sulcate, having thickened prominent points.

\section{Group III. Surface rough.}

Section a. MURICATUM. (Rough surface.)

I. bimaginato-cordatum, Moore. Raised by the late Mr. Elworthy. Dwarf. Broader than bimarginatum; it has also cordate basal lobes. I I $\times \mathrm{O}_{10}^{3}$ inches. Margin toothed.

2. bimarginato-multifidum, Moore. $12 \times \mathrm{o}_{\frac{1}{4}}^{1}$ inches. Brolien up to the rachis; with a divided multifid apex of narrow branches. Sori marginal. An interesting form.

3. bimarginatum, Moore. Found at Ulverston by Mr. IV. Haciwin. Fronds very narrow.

*4. blandum, Lorve. Raised by myself. I $5 \times 1 \frac{1}{2}$ inches. Broad rugose form. Half the width of the frond, next the rachis, quite smooth ; beyond this, a rugose wall, and muricate to the margin.

5. capitatum, Lowe (muricato-capitatum, Jones). Raised by myself. Branching both in stipes and rachis; and forming a close, foliose, rugose, weeping head; fronds stiff.

6. cernuum, Lowe. From the late Colonel Jones's collection. I $X$ I inches. Frond convex, rachis dividing three inches below the apex into a capitate head.

*7. circulum, Lore. Raised by myself. I $\times 0.3$ inches. Densely but minutely rugose; margin bending under; apex weeping and crested. At basal lobes frond $\mathrm{I} \frac{1}{2}$ inches across.

8. columnare, Clapham. Raised by the late Mr. Clapham. $8 \times 0^{\circ} 2$ inches. Linear, and lobate-dentate; with a column-like crest.

9. complicatum, Lowe. Raised by myself. I $4 \times \mathrm{I} \frac{1}{4}$ inches. Irregular rugose margin ; almost plaited ; frond terminating in a rugose crested head, which is twisted ball-like, width $2 \frac{1}{2}$ inches.

Io. corniculatum, Lorve. Raised by myself. $20 \times \mathrm{I}_{4}^{3}$ inches. A fine form of muricatum, with stag's-horn-like head.

II. cristatum, Lowe (muricato-cristatum, Jones). Raised by the late Colonel Jones. Io $\times 0 \frac{1}{2}$ inches. A "mirum" looking form, but so depauperate as to become pinnate. A finely divided capitate head, $2 \frac{1}{2}$ inches across.

* I2. illustre, Lozve. Raised by myself. I $6 \times 2$ inches. Rich green, thick, stiff fronds; very rugose except close to the rachis, where smooth. Apex pointed and twisted. A fine form.

13. inaquale, Lowe (muricato-inæequale, Jones). Raised by the late Colonel Jones. Very minute, and irregularly forked.

14. inframuricatum, Wollaston. Found in 1863 , in Arnbarrow, by Mr. J. M. Barnes. Projections on the under surface.

I5. Jonesii, Lowe (muricato-multifidum, Jones). Raised by the late Colonel Jones. I $3 \times 0$ inches. Strongly rugose, the costa 
even rugose. A twisted rugose head, composed of narrow, long branches. Stipes 6 inches long.

16. lobatum, Lowe (muricato-lobatum, Barnes). Found in 1871 , near Gleeston, by Mrs. Hodgson. Lobate as well as muricate.

17. marginatum, Lowe (rugoso-marginatum, Wollaston). Found in 1862, in Levens Park, by Mr. J. M. Barnes. Rough and underlined.

18. mixtum, Lowe. Raised by myself. $12 \times 1$ inches. Muricate, undulate, and capitate.

19. muricatum, Moore. Found in Guernsey by the late Mr. James, at Nettlecombe by the late Mr. Elworthy, and at Farleton Knot by Mr. J. J. Jones. Muricate on the upper surface.

20. nodosum, Barmes. Found in 1866, at Brigstear, by Mr. J. M. Barnes. Frond kneed.

21. nupta, Lowe. Raised by myself. $12 \times 0 \frac{3}{4}$ inches. Fronds convex ; branching at the top of the stipes. Coarsely rough.

22. peraferens, Lowe (rugoso-peraferens, Jones). A distinct rugose peraferens.

23. prominens, Lowe. Raised by myself. Undulate and spirally twisted. The prominences (which are very stiff) are rufrose at the base, and are half an inch long. $5 \times 1 \frac{1}{2}$ inches.

24. ramosum, Lowe (ramoso-rugosum, Jones). Rugose and branched.

25. revolutum, Lowe. Raised by myself. $10 \times 03$ inches. A tasselled rugose variety, with large, round, basal lobes. Fronds revolving.

*26. Rickettsx, Lowe. Raised by myself. $25 \times 2 \frac{1}{4}$ inches. Broad, and very rugose.

27. rugoso-capitatum, Lowe. Raised by myself. A good capitate rugosum.

28. rugoso-spirale, Lozve. Raised by myself. Stout, rugose, spirally twisted.

*29. scalpturato-latum, Lowe. Found near Scarborough by myself. $23 \times 3 \frac{1}{4}$ inches. Shining; but widely rugose; margin dentate-lobate.

3o. scalpturatum, Moore. Found in Guensey by the late Mr. James, at Nettlecombe by the late Mr. Elwortlyy, in the Isle of Wight by Mr. Bloxam, and near Dalton by Mrs. Hodgson. $12 \times 1 \frac{1}{4}$ inches. Irregularly ridgy and crenate lobed.

*31. spirale, Lowe (muricato-spirale, Jones). A spiral muricatum.

32. striatum, Lozve (muricato-striatum, $M /$ oor $\mathrm{C}$ ). $13 \times 1 \frac{1}{2}$ inches, of which the stipcs is 6 inches. Regularly roughly striate.

33. superbum, Lowe (muricato-superbum, Intice). Raised by myself. $16 \times 2$ inches. A very bold muricate form.

34. tridentiferum, Loree. Raised by myself. $7 \times 0.3$ inches. Very rugose ; margin dentate. Apex trident-shaped.

35. undulatum, loze (undulato-muricatum, Lorece). Raised by myself. $15 \times 1$ it inches. A fine, rery rugrose form, with a bold smooth costa. 
Section $\beta$. SUPRALINEATUM.

(Marginal ridge on upper surface.)

I. constrictum, Lowe (supralineato-constrictum, Moore). Variable; the constricted portion markedly supralineate; sometimes not constricted, but having patch-like processes on the back of the frond.

2. cristatum, Lowe (supralineato-cristatum, Jones). Raised in 1872 by the late Colonel A. M. Jones. I $3 \times 1 \frac{3}{4}$ inches. Supralineate ; and branching at the apex, where 9 inches across.

3. expetitum, Lowe. Raised by myself. $25 \times 3 \frac{1}{2}$ inches. Subrugose and supramarginate. A giant form.

4. fimbriatum, Lowe (supralineato-fimbriatum, Moore). Found in I860, in Levens Park, by Mr. J. M. Barnes. Margin fimbriated.

5. Hartleyi, Lowe (supralineatum Hartleyi, Barnes). Found in 1876 at Kellet by Mr. T. Hartley. A distinct, supralineate variety.

6. Kitsonæ, Lowe (supralineato muricatum Kitson, Jones). I $4 \times 1 \frac{1}{4}$ inches. A singular form ; the linear membrane, a quarter of an inch from the costa and within, concave and smooth, whilst outside this line convex and muricate.

7. lanceolatum, Lowe (supralineato-lanceolatum, Barnes). Found in 1877 at Milnthorpe by Mr. T. Airey. Distinct.

*8. Moonæ, Lowe. Raised by myself in I864. Undulate and supramarginate; the marginal belt conspicuous. Not unlike "undulato-supralineatum" of Jones. I $3 \frac{1}{2} \times 2$ inches. The marginal belt of the latter extends quite to the base.

9. muricatum, Moore. Found in several places. Coriaceous and muricate.

Io. nudo-cristatum, Lowe. Raised by myself. Naked stems.

I I. Phillipsii, Lowe (supralineatum Phillips, Jones). Found in County Fermanagh, Ireland, by Mr. W. H. Phillips.

I2. supralineatum, Moore. Found in 1875 , near Ulverston, by Mrs. Hodgson. A beautiful form, lined on the upper side. Found also in County Clare by Mr. O'Kelly, and at Knocknarea, County Sligo, by Mr. W. H. Phillips.

* I3. supralineatum Lowei, Moore. Raised by myself. A larger and bolder form than No. I2.

14. undulatum, Lowe (undulato-supralineatum, Jones). Raised by the late Colonel Jones. I $4 \times 2$ inches. Only differing from Moonæ in the supralineate membrane extending to, instead of terminating 2 or 3 inches above the base. Moona is much more soriferous.

Section $\gamma$. MARGINATUM. (Marginal ridge on under surface.)

I. aicmoton, Loze. Raised by the late Rev. C. Padley. Margin crenate and dentate; marginate. Apex branched in a fork-like manner. Suprasoriferous.

2. alatum, Moore. Raised by Mr. Clapham. $6 \times 0_{5}^{3}$ inches. Marginate; winged; projecting teeth.

3. amabilc, Lowe. Raised by 1 yself. $16 \times 1 \frac{1}{4}$ inches. Undulate and marginate ; the margin of the frond crimped. 
4. biforme, Wollaston. Found in 1862, in Levens Park, by Mr. J. M. Barnes. Laciniate; many forms.

5. cervi-cornu, Moore. From Messrs. Stansfield. $7 \times 0 \frac{1}{2}$ inches. Branching like stags' horns. Margin densely denticulate.

6. corrugatum, Lowe (marginato-corrugatum, Moore). Narrow ; margined; upper surface decply corrugated.

7. cristatum, Lowe (marginato-cristatum, Woore). Raised both by .Ir Clapham and Mr. Elworthy, and found in 1860 at Arnside 'Tower by MIr. J. M. Barnes. Marginate and crested.

8. fimbriatum, Lowe (marginato-fimbriatum,

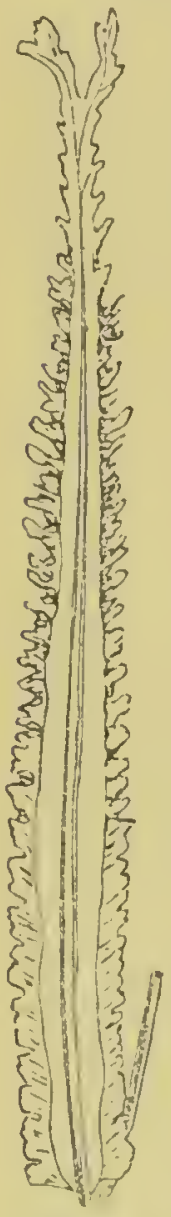

Fig. 3r.

Scolopendrium vulgare, var.

kraspedoumenon (showing marginal line aud (eethi). Moore). Found near Cartmel by Mr. Hillman, in Silverdale by Mr. Stansficld, and in Levens Park (1861) by Mr. J. M. Barnes. Margin fimbriated. $9 \times 0_{4}^{3}$ inches and $10 \times 0_{4}^{1}$ inches.

9. fissum, Lowe (marginato-fissum, Moore). Found at Barnstaple by the late Mr. Jackson, and at Ilfracombe by Mr. J. Dadds. Margin deeply cut into narrow obtuse lobes. Mr. H. Bull has fould this at Mountain, near Chepstow (in 18So). In the Chepstow form the marginal belt is close to the costa.

ıо. irregulare, Lowe (marrinato-irregulare, Moore). Raised by the late Mir. Clapham. A remarkable depauperate form; branching at the apex. Length, 18 inches.

I1. (Fig. 31.) kraspedoumenon, Lorve. Raised by the late Mr. Elworthy. $S \times 0$ inches. Conspicuously dentate; apex furcate.

12. Lyellii, Lowe (bimarginatum Lyell, Jones). Raised by the late Dr. Lyell. $12 \times 0_{4}^{3}$ inches. Rough, but very shining. Dentate.

13. marginato-coronatum, Moore. Margin cut into small rounded lobes; apex coronate, and twisted in a curly manner.

14. marginato-multiceps, Moore. History unknown. $14 \times 1$ inches. Dentate margin; an erect crest. A handsome form of "marginatum.."

15. marginato-multifidum, Moorc. Raised by the late Mr. Elworthy. Length, I2 inches. Slightly flexuose; apex multifid; fronds narrow at base, widening to the apex; marginate cxcrescences.

16. marginatum, Moore. A common form, with an excurrent membane within the margin on the under sicle of the frond. $12 \times 1$ inches.

* 17. mirum, Lore'. Raised by myself. Forms a dwarf, undulate, rugose, twisted, capitate bush. $7 \times \mathrm{O}_{2}^{2}$ inches. IBelow the head small stalked lubes; segments near the lreacl, 4 inches wide.

18. muricatum, Lorve (nuarginatomuricatum, Jones). Marginate and muricate. 
*19. numphion, Lowe. Raised by myself. $4 \times 0 \frac{3}{4}$ inches. A dwarf, rugose, undulate, marginate, sub-peraferens form; with a cuneate head $3 \frac{1}{2}$ inches across.

20. Oakeleyæ, Lowe. Found in 1870 at Penalt (Monmouth) by Mrs. E. Baynall Oakeley. $14 \times 1$ inches. An extraordinary combination. The marginal line has long dentate lobes; margin of the frond deeply fimbriated. Stipes dividing 2 inches from the base ; and at the lower portion of the leafy part minutely pinnate. Surface shining, but rough.

21. optatum, Lorve. Raised by myself. $6 \times 0_{8}^{7}$ inches. Marginate, dentate, and contracted; narrowing to a thickened but pointed apex.

22. papillosum, Lowe (marginato-papillosum, Moore). $9 \times 03$ inches. A double row of projecting fleshy points extends on either side of the midrib, on upper surface.

23. pectinatum, Lowe. From the late Colonel Jones's collection. $17 \times 1 \frac{1}{2}$ inches. A marginate form with the edge cut into teeth a quarter of an inch long.

*24. plicare, Lowe. Raised by myself. $16 \times 1 \frac{3}{4}$ inches. Lobate and muricate ; lobes projecting.

25. ramigerum, Moore. Found in 1865 in Levens Park by Mr. J. M. Barnes. Undulate and branched. No two fronds alike.

26. rugosum, Lorve (rugoso-marginatum, Lowe). Raised by myself. $18 \times 2 \frac{1}{4}$ inches (the stipes 7 inches long). A broad fronded, rugose variety; the margin crenate.

27. sculpturatum Lowei, Lowe. Raised by myself. $16 \times 0_{4}^{3}$ iuches. Very dentate.

28. stenomenon, Lowe. Raised by myself. $14 \times 0 \frac{1}{2}$ inches. An excurrent membrane near the rachis. Narrow; regularly fimbriated. An interesting variety.

29. Studdartii, Lowe (marginatum fimbriatum Studdart, Stansfield). Very pretty when constant.

3o. submarginato-multifidum, Moore. Found at Hackness by the late $\mathrm{Mr}$ Clapham. $12 \times 1 \frac{1}{4}$ inches Margin sinuous; ending in a multifid tuft. A continuous marginal belt.

31. submarginato-ramosum, Lone. Raised by myself. $12 \times 1 \frac{1}{4}$ inches. Branching in the stipes and rachis ; the frond terminating in a flat, branched head 3 inches wide.

32. submarginatum, IVollaston. A common variety. Normal in size, and crenate. Found in lreland by Mr. W. H. Phillips, in Counties Kildare, Wicklow, and Sligo.

*33. tenue, Lowe (marginatum-tenue, Moore). Raised by Mr. S. Appleby. $6 \times 0 \frac{1}{3}$ inches. Laciniate-toothed.

*34. triforme, Lowe. Raised by myself. $16 \times 1$ inches. Shining, though rough; submarginate line thomy ; margin of frond deeply dentate; apex twisting and forming a circle.

35. triumphale, Lowe. Raised by myself. $4 \times 0$ inches. Rugose; the marginal membrane close to the margin, with a dentate edge; crested with a "Cliftii"-like head $\mathrm{I} \frac{1}{2}$ inches across.

36. trossula, Lowe. Raised by myself. $17 \times 0 \frac{1}{2}$ inches. More 
widely and squarely dentate than "stenomenon"; upper half of frond widest; marginal line close to rachis at the base, yet becoming close to the margin at the apex.

37. turgido-irregulare, Moore. Found at Whitby and Nettlecombe. More irregular and more profoundly lobed than "turgidum ;" and marginate.

* 38 . undosum, Love (named in error "marginato-undulatum," Lorve). Raised by myself. $16 \times 1 \frac{1}{4}$ inches. Shining green. A marginate undulatum, with the undulations unusually close.

39. undulato-contractum, Lowe. Found in Devon by the late Mr. C. Jackson. Undulate and irregular in outline; contracted in part of the frond. Partially marginate.

40. undulatum, Lowe (marginato-undulatum, Barnes). Found in 1 S65, at Heversham Head, by Mr. J. M. Barnes. Also in County Clare, by Mr. O'Kelly. A dense, undulate form.

41. venosum, Lowe (marginato venosum, Barnes). Found in I 874 , at Flookborough, by Mr. J. Stewardson. Known by its prominent veins.

\section{Group IV. Margin jagged.}

\section{Section a. CRENATUM. (Margin altered.)}

I. aduncum, Moore. Io $\times$ I inches. Conspicuously lobate; irregular, and apex bifurcate.

2. Aireyi, Lozve (fissum Airey, Barnes). Found in I $S_{77}$, at Milnthorpe, by Mr. T. Airey. A neat, narrow form.

3. alto-lobatum, Lowe. Found at Carron, Co. Clare, by Mr. O'Kelly. Deeply lobed and truncate. $8 \times 1 \frac{1}{2}$ inches.

4. angustato-nitidum, Lowe. Found at Lower Commons, Co. Clare, by Mr. O'Kelly. $12 \times 0 \frac{3}{4}$ inches. Densely fimbrate; hitving a sling frond.

5. contractum, Wollaston. Found in Clare, Guernsey, Smeerset, Nettlecombe, and Ruthin. $10 \times 1$ inches (in widest part). Crenate; contracted below the densely flabellate multifid crest; partly supra-soriferous.

6. crispo-fissum, Barnes. Found in 1877 at Milnthorpe by Mr. T. Aircy. A beautiful, small, narrow, crispy variety.

7. dareoides, Wollaston. Raised by the late Mr. Elworthy. Length, 12 inches. Depauperate, and almost pinnatifid; with lax tecth. The apex much the broaclest part of the frond.

8. dentatum, Clapham. Length, 8 inches. Margin irregular and conspicuously dentate. Apex almost normal.

9. erosum, Lowe. $8 \times 1$ inches. Outline irregular and here and there erose; interruptedly marginate and dentate. $A$ good form has been found at Mucknish, Co. Clare, by Mr. O'Kelly.

10. fissidens, Wollaston. Found in N. Devon. Deeply cut and narrower than "fissum."

11. fissile, Moore. Found at Nettlecombe by the late Mr. E.Lwortliy, and at Mlalton by the litte Mr. C. Monkman. 12XI inches. Irregular, and sub-pinnatitid ; ind crenitte-dentite. 
I2. fissum, Moore. Found in 1862, at Brigsteer, by Mr. J. M. Barnes. Narrow undulate fronds. $15 \times 1$ inches.

13. imperfectum, Wollaston. Found in 1855 , at Whitbarrow, by Mr. G. B. Wollaston. Io $\times 1 \frac{3}{4}$ inches. Fronds defective, broader than "polyschides."

14. inciso-lobatum, Wollaston. Found in 1861 , in N. Devon, by Mr. Dadds, also at Mucknish, Co. Clare, by Mr. O'Kelly. Normal, but incised and lobed.

15. incisum, Barnes. Found in 1861, in Levens Park, by Mr. Barnes. Deeply cut, almost pinnate.

16. irregulare, Padley. Found in S. Devon, in 1865 , by the late Rev. C. Padley. Length, 8 inches. A most irregular variety, having more the appearance of an irregular Asplenium marinum.

17. lobatum, Lowe (crenato-lobatum, Moore). Crenate and lobate. Not uncoinmon. $15 \times 2$ inches.

I8. multifidum, Lorve (crenatomultifidum, Moore). Found in I860, at Birkrig, by Mrs. Hodgson. Margin toothed; and apex crested.

19. mutatum, Moore. Found near Nettlecombe, by Mr. C. Elworthy. I $8 \times 0$ o inches. Incised halfivay to the costa at about half-inch intervals, forming square-ended lobes. The base of the frond narrowest, and the apex broadest.

20. obtuso-dentatum, Moore. Found in 1855 , near Ilfracombe, by the Rev. J. M. Chanter. $12 \times 1 \frac{1}{4}$ inches. Margin notched with uniform crenatures.

*21. omnilacerum, Lowe. Raised by the late Mr. Glave. $22 \times 1$ inches. Erect habit. Lacerated almost to the costa; the lacerations soriferous along their margins. A distinct form. Fig. 32 is an improved form raised by myself.

*22. Padleyense, Lowe. Found in Devon by the late Rev. C. Padley. $24 \times 4$ inches. A very broad, large form. Normal on one side of the costa, and interrupted on the other.

23. pinnatifidum, Moore. Raised by the late Mr. Elworthy. Io $\times 0 \frac{3}{4}$ inches. Narrow at the base; widening to the apex, where rounded. Pinnatifid with deep open sinuses. Mr. Clift raised a similar form. $17 \times 1$ inches.

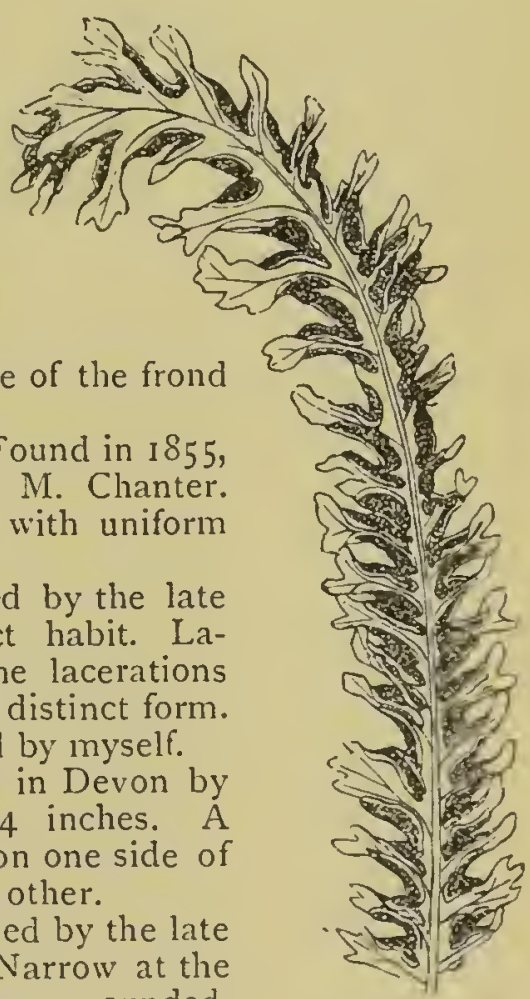

FIG. 32 . omnilacerum Lowei. Tip of frond.

24. polymorphum, Wollaston. Found in I 854, in Sussex, by Mr. Wollaston, and in 1861, at Haversham Head, by Mr. J. M. Barnes. Irregular, and of many forms.

25. prominens, Moore. Found near Ruthin by Mr. T. Pritchard. Length, 12 inches. Irregularly crenate; with fer rounded narrow lobes projecting beyond the general margin half an inch. 
26. serra, Locic. Found at St. Pierre, in I $\delta 87$, by MIr. H. Bull. I $4 \times 1 \frac{1}{2}$. Normal, with a very broad dentate margin.

27. sinuatum, Wollaston. Not uncommon. i $8 \times 0.3$ inches at base and $I \delta \times I \frac{1}{2}$ in upper portion. Margin sinuated with irregular projections; fronds differing from each other.

*28. sub-pinnatum, Noore (semipinnatum, Noore). Found at Ilfracombe by Mr. J. Dadds. $6 \times 2$ inches. Split to the costa into irregular lobes, often distant, with an open sinus. Found also in Sligo, by Mr. W. H. Phillips.

29. suprasoriferum, Lowe. Not uncommon. Crenately lobed, bearing sori on the upper as well as under surface of the frond. I $2 \times 1 \frac{1}{2}$ inches. A dwarf form was found at Mountain, in ISS8, by Mr. Bull, of the St. Pierre Gardens. Margin deeply cut and apex lacerate. Sori near the margin, and as copious above as below. $8 \times 2$ inches.

30. turgido-multificlum, Barnes. Found in I 862 , at Witherslack, by Mr. J. M. Barnes. Thick, rigid, and crested.

3r. turgidum, Wollaston. Found in many places. $12 \times 2$ inches. Coriaceous ; margin very irregular ; apex often multifid.

32. venabulum, Lowe. Raised by myself in $1878.24 \times 1 \frac{1}{4}$ inches (stipes 7 inches). Sub-undulate and deeply lacerate. Erect in habit. Not contracted, like omnilacerum.

\section{Group V. Variegated.}

Section $a$. VARIEGATUM. (Fronds variegated.)

I. albescens, Lnque (albescens variegatum, Moorc). Found, in I S60, at Arnside, by Mr. J. Crossfield. Whole plant crean-coloured.

2. albulum, Lowe. A narrow, sagittate, crested, crispum. Raised by myself. $17 \times 2$ inches. The sagittate lobes long and narrow; with crested tips, and situated at right angles to the costa, variegated with white. Frond narrowing upwards. The late Colonel Jones raised a somewhat similar varicty.

3. album, Low'e (albo-variegatum, Hodgson. Found, in is7r, at Urswick, by Mrs. Hodgson. A beautiful variegated white and green variety.

*4. aureolum, Lowe. A golden varicgated "crispum." Raised by myself in 1887 , together with a number of other forms. Obtained by crossing with a variegated variety. Sagittate lobes, rotund and curling inwards. $16 \times 2$ inches.

5. aureum, Lone (aureo-varicgatum, Lowe). Found near Camperdown by myself in I 867 . Normal, with golden fronds, $16 \times 2$ inches.

6. autumnum, Lowe. Not unlike a golden Kitsonic. Crested, head compact. $12 \times 2$ inches. Kaised by myself in $1 \$ 87$.

7. Claphani, Late' (variegatum Claphami, 1/oori). Beatifully variegated with white; not constant.

S. conglomere, loate. A dwarf, conglomerate, solelen variety. $5 \times 0 \frac{1}{2}$ inches (head $2 \frac{1}{2}$ inches wide). Kilised by myself in 1887.

9. consummatum, Lote. Raised by myself. $12 \times 1 \frac{1}{4}$ inches. Nor- 
mal rigid fronds, striped regularly with thin lines of white, parallel with the veins. Inconstant.

Io. crenatum, Lowe (variegato-crenatum, Wollaston). A fine, variegated crenatun.

I1. crispo-lutescens, Lowe (crispum fimbriato lutescens, Stansfield). A golden crispum. Raised by Messis. Stansfield about 1885 . Very beautiful.

I2. cristatum, Loave (cristatum-lutescens, Stansfield). Raised by Messis. Stanfield in 1885 .

I 3. Elworthii, Lowe (variegatum Elworthii, Moore). A handsome narrow, permanently variegated variety. Found by the late Mr. Elworthy, in Somerset.

I 4. fissum, Lorve (fissum-variegatum). A handsome variegated "fissum." Histcry unknown.

I 5. flavum, Lowe (flavo-variegatum, Barnes). Found in 1865 , near Ulverston, by MIr. J. Crossfield. Normal, with yellow and green variegation.

I6. Grantre, Lowe (crispum variegatum Grant, fones). $12 \times 1 \frac{3}{4}$ inches. A good variegated form in Mrs. Grant's collection.

17. Jonesii, Lowe (cristato-variegatum, fones). Raised by the late Colonel Jones.

I8. lacteolum, Lowe. From the late Colonel Jones's collection. $14 \times 2 \frac{1}{2}$ inches. A normal, broad, variegated variety. The variegation regular : and milky-white.

19. lacteum, Lowe. A cross between Claphami and digitatum. Raised by myself.

*20. luminare, Lozee. A bold golden "crispum." Raised by myself in I\$87. "Cowburni" was one of the parents. Erect. $18 \times 2$ inches.

2 I. lutescens, Stansfield (fimbriato-lutescens, Stansficld). Raised by Messrs. Stansfield in 1885 .

22. Molyi, Lowe (variegatum Moly, fones). A very fine variety.

23. multifidum, Lowe (multifidum lutescens, Jones). I have not seen this.

24. O'Kellyi, Lorve (lutescens O'Kelly, O'Kelly). I $7 \times 1 \frac{3}{4}$ inches. Found at Carron, in County Clare, by Mr. P. B. O'Kelly (I $5 \times$ I inches), who at the same place has found another (albo-lobatum, O'Kelly).

25. peraferum, Lowe (peraferens variegatum, foncs). Found at Colin (Antrim), by Mr. IV. H. Phillips.

26. Phillipsii, Lozve (variegatum Phillipsii, Moore). Found in Colin Glen, Antrim, by Mr. IV. H. Phillips. Fronds margined with ivory white.

27. rugosum, Lowe (rugoso-variegatum, Jones). Raised by myself in 1857.

28. tridentiferum, Iorve. Concave; the apex separating into a trident-head 7 inches across; the tips also trident-formed. A golden variety ro inches in length. Raised by myself in 1887 .

29. variegatum, Moore. Found in 1859, at Arnside, by Mr. J. Crossfield. Normal, but variegated. 


\section{Tribe 10. ASPIDIEAE.}

\section{THE HOLLY FERN.}

ASPIDIUM LONCHITIS.-Swar/z.

(POLYSTICHUM LONCHITIS.-Roth.)

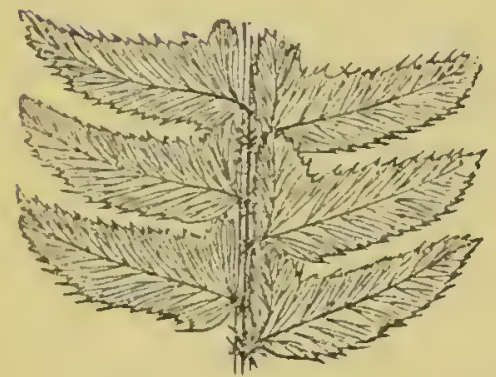

FIG. 33--Aspidium lonchitis.

A MOUNTAIN fern, ranging from 1,000 to 3,000 feet above the sea. It is pinnate, very rigid, and the margin conspicuously spinous. Mostly found amongst stones; frequently the roots running along the roof of small cavernous rocks, and therefore easily detached without injury. In most localities it requires to be grown in a frame in a somewhat moist atmosphere. A difficult fern to cultivate successfully.

Some of its native habitats are now destroyed. It is recorded as having been found on Snowdon; in the English lakes, on Helvellyn, Fairfield, Deepdale, near Ullswater and Farleton Knott ; in several places in Yorkshire; in Teesdale; Ben Lomond, Ben Lawers, Ben Chonzie, Ben Voirlich, Ben Ledi, Clova, and other places in the Fast Highlands; mountains in Inverness, Isle of Mull, Ross, Sutherland, Orkney ; Donegal, Sligo, Leitrim, Meath, and Kierry. Found also on the mountains of Iceland, Lapland, Sweden, and Dermark ; and in the Arctic regions; Germany, Hungary, France, Belgium, Spain, Italy, Switzerland, Greece, Kashmir, Altai, Kantschatka, and the Rocky Mountains.

An evergreen fern with linear lanceolate pinnate fronds from 6 to 8 inches in length, of a rich green colour.

There are but few varieties:-

I. confertum, Lowe. Ireland. Smaller, and imbricated.

2. cristatum. Found on Ben Qui by Dr. Craig. Is well crested.

3. imbricatum, Boyd. Found by Mr. Boycl. Is a distinct imbricated variety. A similar one was received many years ago from Ireland.

4. multifidum, Moore. Multifid, but not constant.

5. proliferum, Moore. I'roducing bulbils in the axils of the lower pinne.

TIE COMNON PRICKLY SHIELI) FERN.

ASPIDIUM ACUIEATUM.-STiarti.

Sub-section. Porstrichum.

A LARGE-GROWING, handsome evergreen fern, which could only be confused witl Aspidium angulare; the pinnules, however, are 
stalkless; with acute-angled or wedge-shaped bases; whilst in A. angulare the pinnules are stalked and their bases obtuse-angled.

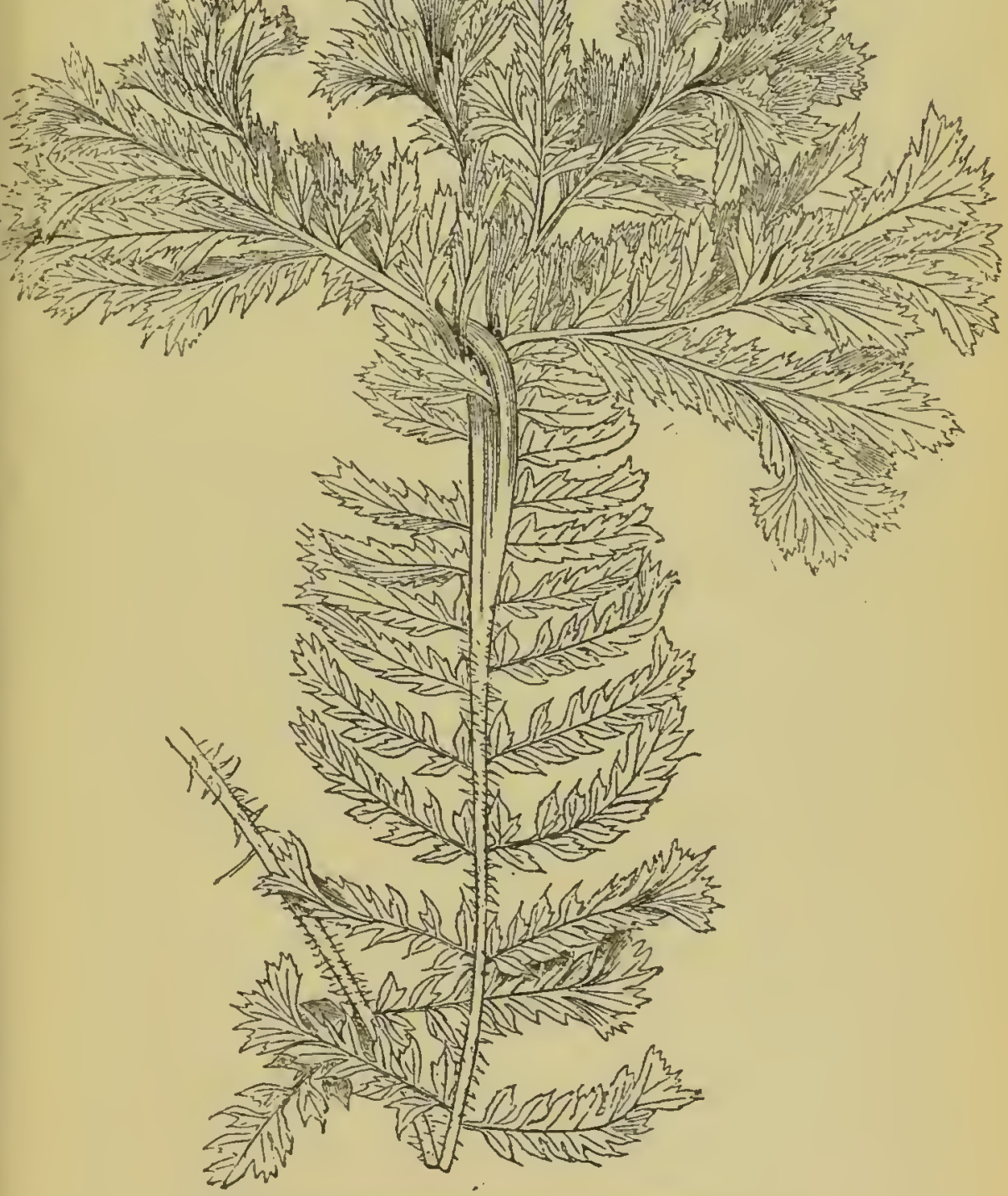

FIG. 34.-Aspidium aculeatum, var. acrocladon.

In $A$. aculeatum the fronds are darker and more shining, stouter and more leathery in texture, and the habit of the plant is more 
erect. Common throughout the United Kingdom and throughout Europe. An inhabitant also of Asia, Algiers, British India, and the United States. A very hardy plant, readily cultivated. It is to be found in liedgerows, woods, and on shady banks. Ordinary length, 2 to 3 feet.

\section{VARIETIES.}

1. Abbotta, Lorve (A. angulare grandiceps Abbott, Jones). A bold and beautiful grandiceps, much larger than No. 2. Found by Mrs. Abbott. Fronds erect. Length, 2 feet.

2. acrocladon, Lowe. Found in 1858, in South Devon, by Mrs. Agar Thompson. Length, 17 inches. A densely crested form.

3. Argutum, Moore. Found in Buckinghamshire by Mr. J. Lloyd. Pinnules narrow.

4. Boltoni, Lowe (corymbiferum, Bames). Found in the Lake district by Mr. Bolton. I $7 \times 6$ inches. Not greatly corymbiferous.

5. capitatum, Jones. A narrow form, widening to a conspicuous capitate head. $27 \times 2 \frac{1}{2}$ inches at base, and 5 inches below the head.

6. caudiculare, Lowe. Found at Shirenewton by myself. $\mathrm{I} 2 \times \mathrm{I} \frac{3}{4}$ inches. A lobed form, having the basal lobes conspicuously stalked and sharp-spined.

7. corymbiferum, Fox (cristatum Fox No. Io, Wollaston). Said by Mr. E. F. Fox, the raiser, to be a hybrid with Aspidium angulare, and from the smallness of the sporangia seems probable, although very like A. angulare. $22 \times 5$ inches. Frond terminating in a conspicuous head.

* 8. cristato-angustatum, Lowe. Raised by myself. Is a copy of cristato-gracilc, except bcing narrower and better crested. II $\times 1 \frac{1}{2}$ inches.

9. cristato-gracile, Bames. Found in $\mathrm{I} 865$, at Hutton Reef Crag, by Mr. T. Bolton. $9 \times 1 \frac{3}{4}$ inches. Very spiny; apex crested.

10. cristatum, Moore. Found at Barnstaple by Mr. H. F. Dempster. Not well crested.

* I. cristatum Lowci, Moore. Raised by myself. IVell crested.

12. densum, Moore. Found in Devon by the late Mr. Jackson. $12 \times 5$ inches. Very foliose and distinct.

13. gracile, Barmes. Found in IS74 near Bowness, by Mr. T. Hartley.

* 14. grandiceps, fones. Raised in IS8I by Mr. E. F. Fox. $17 \times 5 \frac{1}{2}$ inches. Somewhat flexuose. The conspicuous lobe of corymbiferum absent.

* 1 5 . hybridum, Lonve (cruciatum, fones). Raiscd in i 878 by myself. A hybrid between Aspidium angulare, var. Wakeleyanum, and $\Lambda$. aculcatum, var. densum. There are no half-way characters; it is a sudden change from onc species to the other of the cruciate, strapshaped, character. P'revious to this cross, there had been no cruciate A. aculentum. $20 \times 3$ inches. Copiously smiferous; but the spores scldom gemmate; and the descendants are unlike "hybridum."

16. interuptum, Lnate. Found in Noth l)eron by the Rer. F. Mules. $24 \times 5$ inches. $A$ well-maked interrupted form. 
I7. lobatum, Deakin. Found at Shirenewton and elsewhere by myself; and at St. Pierre by Mr. Bull. $30 \times 5$ inches. Larger, and the characters of lobatum better developed than in the original form.

I8. micaceum, Mules. Found near Barnstaple by the Rev. F. Mules. $6 \times \mathrm{I}$ inches. Pinnze almost as broat as long. Said only to grow on a micaceous soil.

19. multifidum, Wollaston. Found in several places in the Lake district and elsewhere. Frond dividing into a tuft of branches.

*2o. nepos, Lowe. Raised from hybridum by Mr. Barnes of Milnthorpe. A narrow, very rough-looking spinous cruciate form. $17 \times 1 \frac{1}{2}$ inches.

21. neptis, Lowe. Raised from hybridum by the late $\mathrm{Mr}$. Carbonell. An interesting variety. $18 \times 3$ inches. This and No. 20 are grandchildren of densum.

22. plumosum, Lowe. Found near Marwood by the Rev. F. Mules. Large and feathery.

23. polydactylum, Fox. Raised by Mr. E. F. Fox. I $4 \times 4$ inches. Pinnce polydactylous. Apex of frond crested.

*24. proliferum, IVollaston (acutilobum, Jones). Found in 1853 by Dr. Allchin. $36 \times 6$ inches. In 1873 the late Mr. John Wills found a very similar plant in Dorset. Not unlike a proliferum (or acutilobum) in $\mathrm{A}$. angulare, but longer and more lax.

*25. pulcherrimum, Jones. Found in 1876 , in Dorset, by a labourer, and given to the late Mr. Wills. It is one of the most beautiful of the British ferns; is sterile, has a very silky appearance, and is a lax proliferum-looking variety.

26. pulchrum, Lowe. Found in North Devon by the late Rev. C. Padley. Narrow; pinnæ minutely crested, the tip of the frond branching into a large foliose head.

27. rotundatum, Lowe (imbricatum, Fox). Raised by Mr. E. F. Fox. $16 \times 2$ inches. An interesting, narrow form. Tips of the pinnae confluent (not imbricate). Pinnules rotund, and the basal ones stalked.

28. stipatum, Lowe. Found in I 890 by Major Cowburn, at Dennil Hill. A bold form, with large stipitate uncut pinnules, having a minute dentate margin. $27 \times 6$ inches.

29. tergeminum, Lozve. Raised from hybridum by the late Mr. Carbonell. Lower pinnæe normal "densum," then cruciate, and here and there brachiate in the pinnæe to near the apex. A bold form. $28 \times 4$ inches.

\section{THE SOFT PRICKLY SHIELD-FERN.}

\section{ASPIDIUM ANGULARE.-Kitaibel.}

Sub-section. POLYsTiCHUM.

SOME of our best authorities consider the present fern as a form of the last, and there is more or less resemblance amongst the varietal forms, but this has a softer feel and a less s: urdy con- 
stitution. To me the greatest proof seems to lic in the difficulty in producing hybrids between A. aculeatum and A. angulare. After many years of perseverance there now exist several undoubted

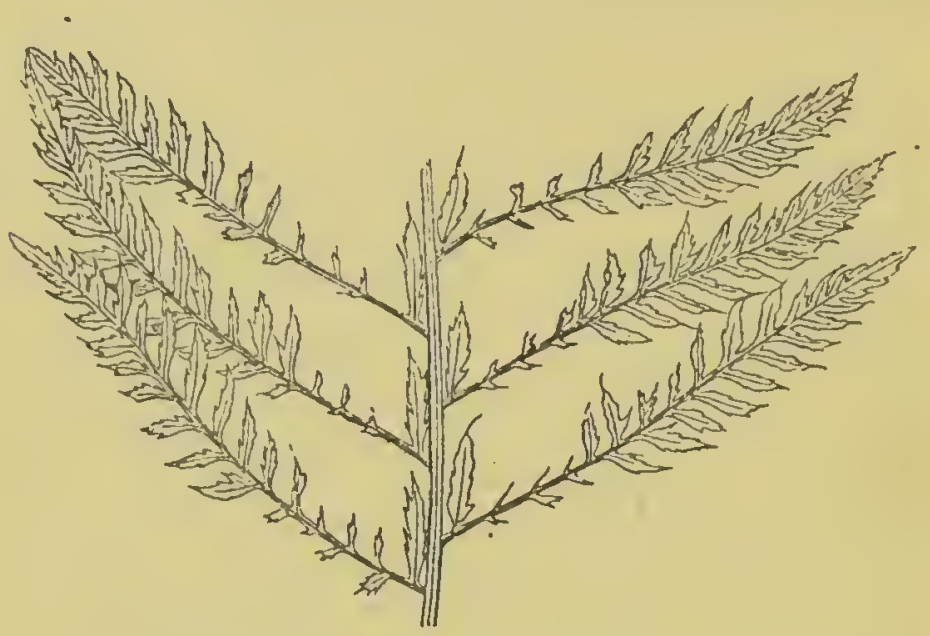

Fig. 35.-Aspidium angulare, var, confluens. Portion of frond.

crosses; and again it is as difficult to raise young plants from these hybrids. If, however, we mix the varieties of the reputed species, i.e. varieties of $\mathrm{A}$. angulare together, or varieties of $\mathrm{A}$. aculcatum, then this difficulty no longer occurs, for scedlings come up by the thousand.

As with the Lady Fern and the Hart's Tongue, this species teems with remarkable varictics, and an attempt at classification has again been resorted to.

A common species, except in Scotland, where only found in a few localities in the Lowlands.

It is so mixed up with the last species by botanists that it is impossible to trace it with certainty on the Continent.

One difference in the normal form of the two ferns is in the pinnules of $\mathrm{A}$. angulare being stalked and having an obtuse-angled basc, whilst in A. aculeatum they are without stalks and acuteangled.*

This species sclects shady woods and hedgerows, ranging from the coast to 600 fect. Evergreen, or subevergreen where cxposed, varying in length from a few inches to 3 feet. More or less linceolate in form; and bipinnate even to quadripinnate. It is difficult with all but botanists to distinguish the present from the last species. Easily cultivated.

* Since this has becn written, Major Coubum has found at I)emil Ilill a varicty of Aspidium Aculeatum, with pinna and pimmles stallicd, and which has been named stipatum. 


\section{VARIETIES.}

\section{Division $A$.}

\section{CHANGES IN SKELETON.}

\section{Group I. Ramosum. (Branching of some part of skeleton.)}

Section a. RAMOSUM. (Stipes branched.)

*. acrocladon, Moore (ramo-cristatum, Jones). Found in South Devon, in 1862 , by Mr. J. E. Mapplebeck. Length of frond, I foot 2 inches; width across the branches, I foot 4 inches. Most profusely branched.

2. Allchini, Lorve (ramo-furcillatum, Allchin). Found in I87 I, in South Devon, by Dr. Allchin. A well-branched variety, bearing bulbils; and almost sterile. Length, I foot 2 inches. Apex crested. 3. capitatum, Lorve. Raised from spores at Highfield House. Frond widest in the middle, and narrowing to the base of a capitate head of 7 or 8 inches across. Pinnae polydactylous. Length, 2 feet; width, 7 inches.

4. cladodesteron, Lowe (viviparum, Jones). Branching from the base; and very much branched to the apex; ending in an erect capitate head. Dwarf; only 5 inches in length.

5. corymbiferum, Lowe (ramo-corymbiferum, Padley). Found in 1863. D warf form; branching from the stipes. Length, 12 inches.

6. furcillatum, Lorve (ramo-furcillatum, Wollaston; ramosum, Jones). A remarkable ramose form, branching from below the rachis, and rebranching several times. Found in 1867, in South Devon, by Mr. G. B. Wollaston. Length, I foot 9 inches; width across the branches, 12 inches.

7. Iveryi, Lowe (multifido-cristatum Ivery, Jones). Better than multifido-cristatum, Moore. $30 \times 10$ inches. Pinna crested, pinnules large. Stipes branching into a large head.

8. Kitsona, Moore (multicristatum, Wollaston). Found at Torquay by Miss Kitson, in 1856 . A fine branched form, the pinnules being altered in form on the upper portion of the frond.

9. multifido-cristatum, Moore. Found in Devon in 1863 by the late Rev. C. Padley. Length, 6 inches. Branching in the middle of the frond.

10. multifidum, Wollaston (Claphami, Moore). Found in 1874 by Mr. J. Wills. Length, 16 inches. Branching in the middle of the frond.

II. projectum, Wollaston. Found in I862, in Devon, by the late Rev. C. Padley of Enville. $18 \times 3$ inches. Curious projecting and ascending branches on the lower half of the frond.

12. ramo-gracile, Wollaston. Found by Mr. Wollaston.

I3. ramo-multifidum, Wills. Found in 1874 by the late Mr. J. Wills. $15 \times 3$ inches, and 9 inches across the branching head. 


\section{Section $\beta . \quad$ GRANDICEPS.}

(Rachis dividing near summit, into numerous branches, and large heads.)

1. accumulatum, Lowe. Raised from spores by myself. A bold grandiceps. An erect grower. $30 \times 10$ inches.

2. capitatum, Clapham (Claphami, Moore; multifidum Clapham, IYollaston). Raised by Mr. Clapham in 1864. A dense capitate head, 12 inches across. Not cristate, except the head. A splendid form. $22 \times 7$ inches.

3. capitosum, Lowe. Found at Tatworth by Mr. Moly. Pinnæ crested. A grandiceps with a head 7 inches across. $28 \times 4 \frac{1}{2}$ inches. * +. coronare, Lowe. Raised from spores given me by the Rev. F. Mlules. Habit erect. An enormous branched head. Lengtl, 2 feet.

5. coronatum, Lowe. Raised by Mr. E. F. Fox. A cross between Molyi and plumosum. Pinna crested; apex crowned (width 7 inches). $15 \times 5$ inches.

6. cristatum, Wollaston (marked IV. No. ro). Found in Somerset by Mr. G. B. Wollaston. Minutely crested, but largely capitate. $2 \mathrm{I} \times 5^{\frac{1}{2}}$ inches.

7. Downense, Lowue. Found at Fermebrogni, Co. Down, by Mr. IV. H. Phillips. $28 \times 6 \frac{1}{2}$ inches. Pinne cristulate. Apex of frond ramulose. Not unlike No. 2.

8. furcans, Wollaston. An interesting fern.

9. grandiceps, Moore (grandiceps Talbot, Wollaston). Found in I $86 \mathrm{I}$, in Co. Cork, by MIr. W. Talbot. A fine form.

*10. incquale-furcans, Cowper. Found by Mrs. Cowper near Sidmouth. $24 \times$ ro inches. Pinnx unequally furcate. A grand capitate head, 8 inches across.

II. Jonesii, Lowe (cristatum Jonesii, Stansfield; grandiceps Jacob Jones, Wollaston). Found in Pembrokeshirc, about 1869, by the late Mr. Jacob Jones.

12. Molyi, Lowe (grandiceps Moly, Wolluston). Found in is69, in South Somerset, by Mr. Moly. A bold, compactly crested variety, with a dense compact head. $19 \times 7 \frac{1}{2}$ inches (where widest, i.e., at the base).

13. nudicaule, Lorve (nudicaule-grandiceps, Barrand). Found near Barnstaple in 1839 . Long bare stalks, and splendid crests. J)istinct.

I4. orbiculatum, Lowee. Found at Langmoor, Charmouth, in I 887 , by Mr. Moly. $21 \times 4$ inclies.

15. Phillipsii, Lorve (capitatum, Phillips). Found at Glenderis by Mr. WV. H. I'hillips. $20 \times 5$ inches. Normal, with capitate head. 16. Praegeri, Lowe (capitatum l'racger, Joncs). Found in $1 \& S_{j}$, in Holywood, by Mr. l'racger. 20x+ inches. Normal, with a grand crested head, 5 inches wide.

17. ramulosum, Shrmsfield. Found in Co. Antrim by Mr. Wr. 11. Phillips. $30 \times 8$ inches. Nomal, with a dense ramulose heatl. 18. scopicoides Lowie. History unknown. From Colonel Jones's 
collection. $16 \times 5$ inches. Short pinnx, large rounded pinnules; costa splitting and forming a besom-like head.

I9. spinigerum, Lowe. Found at Chard by Mi: Moly. A grandiceps with short spiny pinnules. I $5 \times 4$ inches.

20. viviparum, Lore. History unknown. From the late Colonel Jones's collection. A grandiceps with a viviparous head. Length, ro inches. Very irregular.

\section{Section $\gamma$. CRISTATUM. (Bunch crested.)}

I. apuxforme, Moore. Found in $\mathrm{I}_{8} 6_{3}$, at Cunsey, by Mrs. Wilson. Fronds fish-shaped; crested.

2. attenuato-cristatum, Wollaston. Found by Mr. Elworthy.

3. brachiale, Lorve. A superb variety, found in the late Colonel Jones's collection of dried fronds. The superior basal pinnule unequally brachiate; pinnules setose; pinnæe crested; and apex of frond capitate. I $8 \times 6$ inches.

4. Bradburyanum, Jones. A good grandiceps form.

5. Carbonellii, Lowe (cristatum Carbonell, Jones). Slender, but a large grower. Upper pinnules of upper pinnæe incised.

6. Cowperi, Lowe (cristato-gracile Cowper, Wollaston). Found in 1874 , in Dorset, by the late Mr. R. Cowper. Much narrower near the apex. A slender variety, with small crests and pinnules. $16 \times 4$ inches.

7. cristato-gracile, Wollaston (percristatum, Moly). Found in I 868, in South Devon, by Mr. J. Moly. $21 \times 5$ inches. Apex of pinnule conspicuously dentate; crests small. An interesting variety.

8. cristatum, Moore. Under this name there are many forms.

9. cristulum, Lowe (cristatum Stormount, No. I, Prager). Found in I883, at Stormount, by Mr. Praeger. A neat cristulate form, in which the upper part of the midrib of the pinne expands and becomes transparent.

ro. grande, Lowe (capitatum-grande, Fox). Raised by Mr. E. F. Fox. $\quad 14 \times 4$ inches. Normal, with a large, compact head.

I1. inæquale, Lorve (inæequale cristatum, Wollaston). Found in I S63, in South Devon, by Mr. G. B. Wollaston. A singular combination of cresting and depauperation. A small, dense, capitate head. $22 \times 7$ inches.

12. Jacksoni, Lowe (cristato-gracile Jackson, Jones). Found by the late Mr. Jackson. $15 \times 6$ inches. A pretty thorny-looking variety.

13. Jonesii, Lowe (cristato-gracile, Jones). Length, I $\frac{1}{2}$ feet.

I4. laxum, Lowe (cristatum-laxum, Jones). Found in I88I, at Holywood, by Mr. Praeger. I $3 \times 2 \frac{1}{2}$ inches. A nice crested form, with ends of pinnæe confluent.

I 5. Molyi, Lowe (cristato-gracile Moly, Jones). A pretty form.

16. multifidum, Wollaston. A number of varieties have been found ; more or less branched.

7. multilobum, Lowe (multilobum cristatum Jones, Wolleston). Raised in 1873 by the late Colonel Jones. $24 \times 4 \frac{1}{2}$ inches. A very fine, densely crested form. 
18. percristatum, Gray (cristato gracile, Gray'). Minutely crested.

19. Phillipsii, Lowe (cristatum Phillips, Wollaston). Found in I870, in Co. Down, by Mr. W. H. Phillips. A dwarf, broad, crested. variety. Crests small. $12 \times 5$ inches.

20. Praegeri, Lowe (cristatum Castle Dobbs, Praeger). Found in 1884 , at Castle Dobbs, by Mr. Pracger. $28 \times 6$ inches. A lax crested form.

21. setosum, Lore (setoso-cristatum, Moore). Found in 1874 , in South Devon, by Mr. J. Moly. Length, I9 inches. A crested "setosum."

22. subcristatum, Prager. Found in 1885 , at Castle Dobbs, by Mr. Praeger. $12 \times 3 \frac{1}{4}$ inches. Subcrested.

23. Thompsonx, Moore (cristatum Miss. Thompson, Wollezton). Found in 1860, in North Devon, by Mrs. Agar Thompson. A very narrow, close-crested variety, with a compact capitate head. $20 \times 2 \frac{1}{2}$ inches. This fern is sometimes branched and crested.

24. Willsii, Lowe (percristatum, Wills). Found by Mr. IVills. Very distinct. $20 \times 5$ inches.

25. Wollastoni, Lowe (cristatum, Wollaston). $21 \times 6$ inches. Found in 1870 , in Somerset, by Mr. G. B. Wollaston. Narrowing to the large capitate head; crests small.

\section{Section $\delta$. POLYDACTYLUM. (Pinnie digitate, not bunchet.)}

I. conspicuilobum, Lorve (polydactylum-conspicuilobum, Jones). A good polydactylous form. $28 \times 6$ inches.

2. cruciatum, Lowe (cruciato-polydactylum, Jones). $26 \times 2$ inches. In the late Colonel Jones's collection. A good form.

3. erectum, Padley. An erect polydactylum.

4. furcillatum, Phillips. Pinne slightly forked.

5. grande, Lowe (polydactylum grande, Jones). $24 \times 9$ inclies. Very large pinnules. A fine variety.

6. Jonesii, Lowe (polydactylum, Jones). Found in Hampshire in 1875. It differs from Padleyi in having the two pairs of basal pinna much longer than the rest, and in the rachis dividing some 6 inches from the apex of the frond, and again subdividing into a crested head 8 inches broad. $24 \times 6$ inches (at base).

7. Padlcyi, Lowe (polydactylum, Padley). Found in IS62, in the Vale of Avoca, by the late Rev. C. Padley. Frond slightly narrower at the base and scarcely polydactylous at the apex. $24 \times 6$ inches.

S. polydactylum, Moore. Found in Tipperary in $1 \$_{57}$. A slender crested form.

9. ramoso-pinnatum, Jones. $24 \times 6$ inches (at base). A lax, acute, pinnuled form, with branching pinne on the basal half of the frond.

10. scalptum, Carbonell. Raised by the late Mr. Carbonell. A slender polydactylous decompositum. $15 \times 5$ inches.

II. splendens, Lor'c (polydactylum splendens, Jomes). Raised by the late Coloncl Jones from Mr. Padley's Vale of Aroca polydicitylum. 
12. Willsii, Lowe. Found by the late Mr. Wills. A subrotundate crested variety.

13. Wollastoni, Lowe (polydactylum, Wollaston). Found in I 870 , in Somerset, by Mr. G. B. Wollaston. Conspicuously polydactylous and capitate; peculiar cut pinnules, ending in a sharp point. $20 \times 5 \frac{1}{2}$ inches.

\section{Section $\epsilon$. BRACHIATUM.}

(Rachis branching into three near the base.)

1. brachiatum, Gray. Found in 1860, in South Devon, by the late Mr. R. J. Gray, and at Axminster by Mr. Moly. $2 \mathrm{I} \times 5$ inches (base, 14 inches). Basal branches make the frond triangular. Mr. Gray raised very many brachiate seedlings.

2. capitatum, Wollaston. Found in 1862, in Dorset, by Mr. J. Moly. Length, 12 inches. Short irregular pinne and a large capitate head ( 8 inches broad).

3. coronare, Lowe (brachiato-cristatum, Gray, in part). Raised by Mr. R. J. Gray.

4. deltoideo-decompositum, Moly. Found in 1874 , in Devon, by Mr. Moly. $2 \mathrm{I} \times 5$ inches (basal pinna 9 inches). An interesting form.

5. furcillatum, Lowe (brachiato-furcillatum, IVollaston). Found in 1874 in Hampshire by the late Colonel Jones. Length, 24 inches. Width across basal branches, 14 inches. Tips of pinnæe forked minutely.

6. Grayi, Moore (brachiato-cristatum, Wollaston). Found in I 854, in South Devon, by Mr. R. J. Gray. Length and breadth, i 8 inches. Mostly branching in the leafy portion of the frond at its base into a magnificent tree-like frond with three conglomerate lieads. Mr. Gray raised many forms of this variety.

7. Hankeyi, Lowe (brachiato-cristatum Hankey, Wollaston). Found in Sussex, in 1866, by Mr. Barnard Hankey. $21 \times 6$ inches (except brachiate base, where 12 inches). Frond capitate, the head 7 inches across. A marvellous form, with pinnules plumosely dentate. There is a brachiate character with all the pinne.

8. Jonesii, Lowe (brachiato-cristatum, Jones). Found in 1873, in Hampshire, by the late Colonel Jones. Length, 15 inches. Much depauperated.

9. Keallii, Lowe (brachiato-cristatum, Keall). Length, 15 inches; width, 12 inches. A fine form, found by Mr. Keall, in which each of the two branches is as large as the central frond; the apices in all are branched and their tips crested. Mr. Elworthy found a very similar variety.

ro. Kitsonie, Moore (brachiato-cristatum, Kitson). Found in I $8 ; 6$, in South Devon, by Miss Kitson. $20 \times 7$ inches. A very singular brachiate form, with fan-shaped feathery pinnules.

1I. minor, Lowe (brachiato-cristatum Wills No. 3, Wollaston). Found in 1873 , in Dorset, by Mr. W'ills. Length, 12 inches.

12. multifidum, Lowe (brachiato-multifidum, Jones). Found in 
I 877 in Dorset by the late Mr. J. Wills. I $8 \times 13$ inches. Branched in the middle of the rachis, and each again near the apcx. Naked stem, 6 inches.

33. O'Kellyi, Lowe (brachiatum O'Kelly, Jones). Dwarf, and sterile.

14. Padleyi, Lowe (brachiato-cristatum, Padley). Found in Sussex by MIr. W. Barnard Hankey in 1866 . Length, I foot 8 inches. 'Ten years previously, Mr. Gray', of Exetcr', found this varicty in South Devon. Recently, Mr. W. H. Phillips has found it in County Down. "Padleyi" branches in capitate heads.

r 5. Phillipsii, Lowe (brachiatum of Phillips, Jones). Found at Stormont by Mr. IV. H. Phillips. $35 \times 10$ inches. A lax form. The brachiate part 16 inches wide.

I6. polyclados, Moore (brachiato-cristatum Elworthy, Wollasfon). Found in 1857 in Somerset. Flexuose. Length, 15 inches, very irregular. Apex of frond branched horizontally; large crested licad.

* 7. Snithii, Lowe (brachiatum cristatum Smithii, Mapplebeck). I have not scen this.

IS. Willsii, Lowe (brachiato-cristatum IVills No. 4, Wollaston). Found in 1876, in Dorset, by Mr. Wills. Very plumose pinnules. Small capitate apex of frond. $20 \times 7$ inches; and across basal pinna, ro inches.

\section{Section $\zeta$. CRUCIATUM.}

(Pinnæe or pinnules twin-branched.)

* I. Cliftonre, Lozve. Raised by myself. Erect; well cruciatc ; having a large capitate heacl.

2. cruciato-pinnulum, Fox. Found in 1873 , in Dorset, by Mr: J. Moly. $2 \mathrm{I} \times 5$ inches. Cruciate pinnules. Apex caudate.

3. cruciato-polydactylum, Jones (cruciato-cristatum, If ollaston). Raised in 1874 by the late Colonel Joncs. A crested variety. $27 \times 3$ inches.

4. cruciatum, Wollaston. Found in r 862 , in Somerset, by Mr. G. B. Wollaston. $30 \times 2$ inches. Cruciate above the centre of the frond.

5. Elworthii, Moore (cruciato-truncatum, Jones). Found in is 54 , in Somerset, by the late Mr. Elworthy. $14 \times 1$ inclics, except bclow the truncate apex, where there are 3 or 4 long pinnie.

*6. laudatum, Lowe. Raised from spores. A very narrow form of large size. $30 \times 3$ inches.

7. majus, Lowe (cruciatum-majus, Jonis). The boldest cruciatum yet found. $34 \times 42$ inches.

*S. transforme, Lotes. Only an occasional pinna cruciate. I'inne ascending very short and confluent. Habit erect. Length, 2 feet. Colonel Jones has this marked subcructitum in lis collection.

9. Wakeleyanum, Hoore (cruciato-mulificlum Russell, Jones). Found in 1860 , in S. I)cron. A nirrow, well-cruciated variety, with a crested apex. $30 \times 1 \frac{1}{2}$ inches.

ı. Willsii, Loowe (cruciatum Wills, Jones). 


\section{Group II. Dwarfed.}

(Abbreviation of skeletal axis in relation to soft parts.)

Section a. CONGESTUM. (Central axis abbreviated.)

I. annutum, Moore (conspicuo-crispatum, Jones). A dwarf crispate form. Possibly the same as coriaceo-crispatum, Jones.

2. Carbonellii, Lorve (obtusissimum Carbonell, Fo.r). Found in $\mathrm{ISS}_{3}$, at Littleham, by the late $\mathrm{M}_{1}$. Carbonell. $16 \times 3$ inches. Imbricate, pinnules falcate with blunt ends ; very neat.

3. confertum, Padley (congestum, Wollaston). Found in $186_{5}$, in South Devon, by the Rev. C. Padley. A dense, congested form, with pinna overlapping. $14 \times 5$ inches.

4. crispatum, Jones. Found at Hale, near Salisbury, by the late Colonel Jones. Crisped.

5. decurtum, Lowe. Found at Holditch by Mr. Moly. Narrow, and imbricated. $15 \times 2 \frac{1}{2}$ inches.

6. Lyellii, Lowe (congestum Lyell, Jones). Raised by Dr. Lyell. A fine congested form, crisped, and occasionally closely branching at the apex.

7. micron, Lorer. Found in Braunton, by the late Rev. F. Mules. $8 \times 2 \frac{1}{2}$ inches. A stiff, wire-like fern of the gracile type.

8. multifidum, Lorve (congesto-multifidum, Jones). Raised by the late Colonel Jones. $8 \times 4 \frac{1}{2}$ inches. Piunæe much branched; costa splitting and forming a branched head.

9. obtusissimum, Moore. Found in I86r, at Ottery St. Mary, Devon, by Mr. G. B. Wollaston. Pinne narrow and imbricated, and somewhat blunt-ended. A handsome variety. I $8 \times 4$ inches.

Io. parvissimum, Moore. Less in size. Length, 6 inches.

I1. polydactylum, Lowe (polydactylum-congestum, Fox). A cross between congestum, Wills, and polydactylum, Joncs. Raised by Mr. E. F. Fox. $8 \times 2 \frac{3}{4}$ inches. Apex multifid, not crested.

12. stipatum, Wollaston. Found by Mr. Tait. Pinne sliort, crowded and overlapping ; pinnules also crowded and overlapping.

13. truncatum, Lowe (truncatum Mrs. Cowper, Wollaston). Found in 1871 , in South Devon, by Mrs. C. Cowper (3, The Residences, South Kensington Museum). Basal pinnæ largest; flexuose; apex of frond truncate and cornute. Very foliose. Io $\times 9$ inches.

14. turgidum, Moore. Found at Littleham, Devon, by the late Rev. C. Padley. Dwarf. $9 \times 2$ inches.

I5. Willsii, Lowe (congestum Wills, Jones). Divarf; beautiful.

\section{Section $\beta$. ALATUM.}

(Lateral axes abbreviated, pinnules more or less confluent.)

1. alatum, Moore. Found in Somerset by Mrs. Thompson, and in Devon by Mr. Wollaston. Pinnules joined together by a welldeveloped wing. A dwarf variety. 
2. angustifions, Moore. Found at Barnstaple by the late Mr Jackson. $8 \times 1$ inches. Exceedingly narrow.

3. extremum, Lowe. Found in Devon, in $\mathrm{I} 864$, by the late Mr. C. Elworthy. $14 \times 3$ inches. Allied to obtusissimum. Pinna touching, but not overlapping.

4. Hartleyi, Lorve (alatum Hartleyi, Barmes). Found in I870, on Furness Fell, by Mr. T. Hartley. Distinct; pinnules confluent and imbricated.

5. imbricatum, Moore. A narrow, imbricated, very lax form, found in Somerset by the late Mr. Elworthy. Length, 24 inches. Proliferous.

6. pterophorum, Moore. Found in Devon by Mr. G. B. Wollaston. $24 \times 3 \frac{1}{2}$ inches. An ally of alatum.

7. pumilum, Monre. Found near Nettlecombe by Mr. Elworthy. $9 \times 2$ inclies. Almost recurved.

\section{Group III. Flexuose.}

(Abnormal curving of skeleton.)

Section a. FLEXUOSUM.

I. abasipinnulum, Moore (medio-deficiens, Padlcy). Found in Dorset, in 1876 , by Mr. R. Thompson (3, The Residences, South Kensington Museum). A flexuose varicty, not unlike gracile in general appearance. The threc or four basal pinnules, to within two inches of the tip of the frond, reduced to the stem of the pinnulc. $22 \times 5$ inches.

2. flexuosum, Wollaston. Mr. Wollaston, betwcen s 870 and I \$73, found sevcral plants in North Somerset and South Devon that varied in the flexuose character. The stipes and rachis bending in an cxtraordinary manner. $20 \times 5$ inclies. A dwarf form in the Clifton Zoological Gardens was possibly raised from flexuosum.

3. grandidens, Lozve (grandidens flexuosum, Moly). Found in I870, in Devon, by Mr. J. Moly. A narrow, depaupcrate form, in which the upper part curls round. I $4 \times 1$ inches.

4. pendens, Lowe (flexuoso-pendens, M'ills). Lax and beatiful.

5. reflexum, Wollaston. Found in Devon by Mr. G. B. Wollaston, pinnules reflexed.

6. revolutum, Lozve: Found by myself, in $\mathrm{I} S \$ 7$, in a hedge at Shirenewton. $22 \times 3$ inches. Rather larger and bolkler than revolrens.

7. revolvens, Hoorc. Found in 1872, in Somerset, by Mr. I. Wills. I $8 \times 2$ inclies. The pinna revolve, curving over the back of the frond, and by this means shortening their width one half.

S. subrotundatum, Bellairs. Found in Deron about i $\$ 65$ by Miss liellairs. $16 \times 2 \frac{1}{2}$ inches. A subflexuous form, and subrotundatc. Pinnac flexuose and ascending. 


\section{Group VI. Stipitate.}

(Pinnce and pinnules distinctly stalked.)

Section a. STIPATUM.

I. deorsopinnatum, Moore. Found in $187 \mathrm{I}$, in South Devon, by Mi. J. Moly. The inferior pinnules much the larger. $27 \times 9$ inches. 2. Hodgsoni, Lozve (stipitatum, Wollaston). Found in IS66 in Gleeston Lane by Mr. J. K. Hodgson. A dense, distinct form, with crowded pinnules.

3. Jonesii, Lorve (deorsopinnatum Jones, Jones). A distinct form, raised by the late Colonel Jones.

4. levidense, Wollezston. Found in I 866, at Windermere, by Mr. J. M. Barnes. Pinnules thin, and long-stalked.

5. pediculatum, Lorve (pediculatum Hodgson, Jones). Found in I 869, near Ulverston, by Miss Hodgson. Pinnules long-stalked.

6. Praegeri, Lorve (deorso-pinnatum Praeger, Jones).

7. stipitatum, Moore. This and pedicellatum, Wills, are much alike. Known at the Todmorden Nursery as far back as I 865 .

\section{Division B.}

\section{CHANGES IN SOFT PARTS.}

\section{Group I. Amplum. (Increased development.)}

Section a. PLUMOSUM.

(Texture thin. Fructification scanty or absent.)

I. Cooperi, Lowe. Found at Braunton by Mrs. S. Cooper. A dense, large pinnuled form. I $8 \times 5 \frac{1}{2}$ inches.

*2. coronare, Lowve (plumosum coronare, Lorve). Raised by myself in I 887. Densely bunch-crested.

3. Daddsii, Low' (plumosum Dadds, Jones). Neat.

4. grande, Jones. Raised by Mr. E. F. Fox from spores (of decompositum-splendens) supplied by the late Colonel Jones; and from which also the three magnificent plumose divisolobes were raised by Mr. Fox. A barren handsome form. $28 \times 9$ inches.

5. Hillersdonense, Lozve (plumosum Hillersdon, Jones). One of Mrs. Giant's beauties.

6. laxum, Jones. A superb fern, raised by the late Colonel Jones. *7. Mousogines, Lorwe. Purchased in Yorkshire. Not unlike Pateyi, but without the large basal pinnæ; and occasionally bear$n g$ bulbils at the apex of the frond. $32 \times 7 \frac{1}{2}$ inches. A splendid orm.

8. Pateyi, Moore (plumosum Patey, Wollaston). Found in I866, n Dorset, by Mr. G. E. Patey. A magnificent, sterile, plumose orm with extraordinary development. $22 \times 7$ inches (except at Jase, where I I inches).

9. plumatile, Lorve. A distinct feathery form raised by myself n I $S S_{4}$. 
10. plumosum, Moore. Found in Somerset in 1956 by the late Mr. C. Elworthy. A sterile form, $36 \times 9$ inches.

II. Wollastoni, Lowe (plumosum Wollaston, Hollaston). Found in Devon by Mr. G. B. Wollaston. Less lax than plumosum, and fertile.

\section{Section $\beta$. FOLIOSUM.}

(Foliose or subplumose. Texture and fructification nomal.)

I. bulbiferum, Lowe (frondoso-bulbiferum, Jones). A grand foliosum, developing bulbils into little plants (some as much as 2 inches long) at the base of the pinna. As many as 50 plants on a frond. $30 \times 7$ inches.

2. Concinnum, Noore. Found near Nettlecombe by the late Mir. C. Elworthy. A pretty foliose variety. $24 \times 6$ inches.

3. crispum, Lowe (foliaso-crispum, Jones).

4. cristatum, Lotve (folioso-cristatum, Jones).

5. cruciatum, Lowe (frondoso-cruciatum, Jones). History obscure.

6. foliosum, Hollaston. Found near Romsey, Hants, by Mr. G. B. Wollaston. A handsome leafy form with overlapping pinnie and crowded pinnules.

7. frondosum, Jones. A densely foliose yet refined variety. $24 \times 10$ inches.

8. imbricato-crispatum, Plitlips. Overlapping and crisp. $24 \times 6$ inches.

*9. Jonesii, Lorve (foliosum, Jones). Found by the late Colonel Jones. When vigrorous, lower pinnules fatcate. Both Mr. WVills and Mr. F. W. Stansfield pointed out this as suggestive of the pulcherrimum typc.

10. latipes, Waore. Raised in 1870 by Mr. Parsons. A fine foliose form. $27 \times 8$ inclies.

11. multifidum, Lorve (folioso-multifidum, Jones). A fine variety with solid rotund pinnules. Stipes dividing considerably below the apex into a capitate head (8 inches across). $20 \times 4 \frac{1}{2}$ inches.

I2. Parsonsii, Lorve (crispato-foliosum, Parsons). Raised in 1872 , at Danesbury (Herts), by Mr. Parsons. A handsome, thomy; fringed, foliose form. $21 \times 6.2$ inches.

13. polydactylum, Lowe (frondoso-polydictylum, Jones). A foliose and polydactylous variety. $30 \times 7$ inches.

\section{Section $\gamma$. PULCHERRIMUM. (Ultra plumose.)}

[Lower pinnules, and somctimes upper, falcate, lecply incised, and drawn out into threat-like processes. Fructification gencrally aposporous. Character more or less intemittent.]

I. Molyi, Losie (pulcherrimum Moly, Jones; and caudiculato cristatum, IVollastom). Found in 1876 in S. Devon by Mr. Moly: pips of the pinna crisped and feathery. Mr. Moly also found other forms, from one of which $M \mathrm{r}$. L. WV. Stansficlel hats raised scedlings by apospory. The kev. C. Pitclley also found a pul- 
cherrimum, from which Mr. Morris of Bath has raised seedlings by apospory (Mr. Moly also found a characteristic pulcherrimum with variegated fronds. See section variegatum). $24 \times 5$ inches.

2. pulcherrimum, Moore (pulcherrimum Wills, Wollaston). Found in Dorset by the late Mr. Wills.

3. Thompsonx, Lowe (pulcherrimum Mrs. Thompson, Jones). Found in 1863 , in S. Devon, by Mrs. Agar Thompson. A most feather-like variety, especially near the tips of the pinnæ. $27 \times 6$ inches (in the middle of the fronds).

\section{Section $\delta$. MACROPINNULUM.}

\section{(Unusually large pinnules.)}

I. cristatum, Lowe (latifolio-cristatum, Jones). Raised by the late Colonel Jones. $1 \& \times 9$ inches. Lax, and slightly crested.

2. divisum, Smith. Found in I 869 in S. Devon by Mr. Moly. I $8 \times 6$ inches. Lax. A number of forms have been found.

3. globosum, Lowe (latifolio-globosum, Jones). Lax, with glc: bose crests and a branched head. Distinct. $20 \times+$ inches.

* 4 . grandiceps, Lozve (latifolio-grandiceps, Jones). Raised b the late Colonel Jones. $14 \times 7$ inches, having a tasselled heald inches long.

5. Jonesii, Lowe (pendens Jones, Jones). Found in 1873 , in Dorset, by the late Colonel Jones. A lax, large-pinnuled form. $27 \times 7$ inches.

6. latifolium, Wollaston. Found in 1873 in S. Devon by Mr. J. Moly. $32 \times 10$ inches. One of our finest varieties. The development of the posterior basal pinnules is very exceptional.

7. latitudine, Lowe. $22 \times 12$ inches. A frond found in the late Colonel Jones's collection, apparently raised from latifolium. A lovely, slender form.

8. pendens, Lorve (pendens Wills, Jones). A very handsome form, found by the late Mr. Wills. $24 \times 5 \frac{1}{2}$ inches.

\section{Group II. Exiguum.}

(Diminished development of soft parts.)

Section $a$. LAXUM.

(Pinnæ and pinnules distant.)

I. acutilobum, Lowe (gracile Grayi, Gray). Found in 1865 , in j. Deron, by Mr. R. J. Gray. Length, 2 feet 3 inches. An acutiobe of the finer kind.

2. Jonesii, Lowe (laxum Jones, Jones). Found by the late Eolonel Jones.

3. laxum, Moore. Found in Devon by the late Rev. C. Padley. -ength, 17 inches. Pinnee and pinnules lax.

4. Molyi, Lowe (laxum Moly, Jones). Found by Mr. Moly.

5. Padleyi, Lowe (gracile Padley, Jones). Found by the late Rev. C. Padley. 


\section{Group III. Compositum. (Subdivision of pinnules.)}

\section{Section a. DECOMPOSITUMI.}

(Subdivision on normal lines.)

I. Clowesii, Lowe (decompositum Clowesii, Aloore). Found in I 860 , at Whitbarrow, by Mr. F. Clowes. Robust, dense, plumose, with profoundly cut pinnules. A similar wariety was found at Arnside by Mr. J. Crossfield.

2. decompositum, Moule. Found by Mr. Moule in Devon.

3. Foxii, Loa'e (decompositum Fox, Jones). Large.

4. frondosum, Loa'e (frondoso-decompositum, Jones). A delicate foliose form. $24 \times 9$ inches.

5. Gillettii, Lor'e (tripinnatum Gillett, Joncs). Found in IS64, near Ieovil (Somerset), by Mr. Cillett, of Cirencester. A grand form, densely foliose. $27 \times 14$ inches.

6. grande, Low' (decompositum grande, Jones). $3 S \times 12$ inches. Found at Torquay by the late Colonel Jones (in $1870-2$ ).

7. Jonesii, Lowe (decompositum splendens, Jones). Raised by the late Colonel Jones. Distinct and fine.

S. laxum, Loewe (decompositum-laxum, Wollaston). Found in I 876 , at Brislington, near Bristol, by Mr. E. F. Fox. A large, bold form. $33 \times 10$ inches.

9. magnifico-polydactylum, Lozve (decompositum magnificum polydactylum, Jones).

IO. magnificum, Lowe (decompositum magnificum No. 3, Jones). $2 S \times 12$ inches.

I1. Padleyi, Loa'e (tripinnatum Padley, Jones). Found in i $\$ 72$, in North Devon, by the late Rev. C. Padley. Colonel Jones remarks, "The divergence of the anterior pinnules from the prinary rachis is remarkable." Dense overlapping pinnx. $18 \times 6 \frac{1}{2}$ inches.

12. Phillipsii, Lowe (decompositum lhillips, Jones). Found in Co. Down by Mlr. W. H. Phillips. $16 \times 5 \frac{1}{2}$ inches.

I3. plumosum, Lorve (plumoso-rlecompositum, fones). The late Colonel Jones raised three interesting forms from his multilobumlaxum. $15 \times 5$ inches.

14. Praegreri, Loace (tripinnatum Pracger, Jones). Found in ISSG, at Dundonald, by Mr. Praeger. $27 \times 7$ inches. A distinct tripinnate form.

15. serrulatum, Wollaston (deltoides-decompositum, Stansficlit). Raised by Messi's. F. WV. and H. Stansfield. It is stipitite, deltoid, and decompound; with strongly toothed pinnules.

16. splendens, Low' (decompositum splendens Moly, IT ollarton). Found in 1875 , in S. 1)evon, by Mi. J. Moly. Contrast of development in centic of frond renarkable. $34 \times 5$ inclies. from this Mr. E. F. Fox raised the grand divisolobums named by the late Colonel Jones, densum, robarstum, and harmm; described in Section $\delta$.

17. tripinnatum, Hoore. A confusion has occurted with regard to this plant; it was originally found by Mr. R. "Tracy' Millett, of l'enzance, and named by Mlr. Noore. (See page 155, rol. I. 
Nature-Printed British Ferns," by Thomas Moore.) In the original plant the pinnze were twisted so as to lie one above the nther like stairs. It is not so decidedly tripinnate as Gillettii, and altogether a different-looking plant. Found also in the English Lake district.

\section{Section $\beta$. ACUTILOBU.M.}

(Pinnules acute-lobed, upper and lower ones of equal length.)

I. acutilobum, Wollaston. Raised from spores by Mr. Wollaston in $1873.3+\times 3$ inches; in middle of frond, only 2 inches.

2. acutissimum, Wollaston.

3. acutum, Lozee (acutilobum acutum IVills, Jones). Crowded with bulbils along the rachis.

4. Allchini, Lozve (proliferum Allchin, Jones). Also copiously bulbiferous.

*5. arctissimum (Lowe). A very narrow form, raised at Highfield House. Apex attenuate.

*6. conspicuum, Lowe (proliferum-conspicuum, Lowe). Raised from spores. Very lax in every part of the frond. $25 \times 13$ inches. Narrowing from the base. The superior basal lobe at right angles to the pinnule.

7. cruciatum, Lorve (acutilobum cruciatum, fones). An interesting form. $24 \times 2 \frac{1}{2}$ inches.

8. exile, Loze (acutilobum exile, Phillips). Found at Holywood by $\mathrm{Mr}$. IV. H. Phillips. $12 \times 3 \frac{1}{2}$ inches. A pretty form. Mr. Phillips has found other sub-forms.

9. Footii, Lowe (proliferum Footii, Jones). Found in Co. Clare by Mr. F. J. Foot. Length, 2 feet. Segments more crowded than in proliferum.

* Io. Fraseri, Lowe (proliferum Fraseri, Lowe). Raised from spores at Highfield House. A narrow acutilobe variety. The pinnæe and pinnules very lax. $18 \times 5$ inches.

II. grandiceps, Lozve (acutilobum grandiceps, Wollaston). Raised in 1874 by Mr. G. B. Wollaston. Narrow, branching, and crested. I $8 \times 2 \frac{1}{2}$ inches.

I2. Grayi, Lowe (gracile Grayi, Gray). Found in 1865 , in South Devon, by Mr. R. J. Gray. $27 \times 6 \frac{1}{2}$ inches. Very slender and acutelobed. A narrower form was found in 1860 , in Hampshire, by Mr. T. B. Rake, which is more divisolobe. Length, 2 feet.

13. Hankeyi, Lowe (acutilobum Hankey, Joncs). A fine form, not proliferous.

14. Hartleyx, Lowe (acutilobum Hartley, Wollaston). Found in $\mathrm{I} 863$, on Furness Fell, by Mrs. Hartley. A beautiful variety, erect in habit and acute in all its parts.

I 5. laciniare, Lorve. Found at Coombpyne, Deron, by Mr. Moly. A lovely lace-like form. $2+\times 6 \frac{1}{3}$ inches.

16. Masoni, Lozve (prolicerum Masoni, Bimes). Found in 1868, at Humphrey Head, by Mr. A. Mason. A finely-cut, bulbbearing variety'. 
17. oxyphyllum, Moore (divisolobum Elworthy, Wollaston). Found in 1852 , in Somerset, by the late Mr. Elworthy. $21 \times 6$ inches.

1S. Phillipsii, Lore (acutilobum, Phillips). Found in Co. Down by Mr. IV. H. Jhillips. $20 \times 5$ inches. Rather lax.

* I9. pictorum, Lowe.

20. Praeǵeri, Lotue (acutum Praeger, Jones). Found in ISS2, at Dundonald, by Mr. Jraeger. $14 \times 3 \frac{1}{2}$ inches.

21. proliferum, Moorc. There are many similar forms; onc found in 1876 , in Dorsct, by $M \mathrm{r}$. Wills, is more proliferous than Mr. Choulc's original plant. $24 \times 6 \frac{1}{2}$ inches.

22. scopx, Lowe. Raised from spores, at Shircnewton Hall (from vars. polydactylum and multilobum). A very divisilobum-looking variety, with pinne heavily crested. The late Colonel Jones raised four scedlings very like the present onc, but larger.

23. tenuc, Loric (proliterum tenue, Clapham). Raised by the late Mr. Clapham. I $4 \times 3 \frac{1}{4}$ inches. Lax.

24. Willsii, Lorve (acutilobum proliferum WVills, IVollaston). Found in 1876 , in Dorset, by Mr. J. Wills. Length, 2 fect. Robust and proliferous.

25. Wollastoni, Loze (proliferum Wollastoni, Moore; acutilobum proliferum, Wollaston). Found in 1852 , in South Deron, by $\mathrm{Mr}$. G. J3. Wollaston. A very interesting fern. $30 \times 7$ inches.

\section{Section $\gamma$. DIVISOLOBUMT.}

(Pinnules eut into acute lobes; lower pinnules distinctly larger than the upper ones.)

I. acutum, Loze (divisolobum acutum, Jones). Found by Mr. Padley. An interesting lax form. $22 \times$ ro inches.

2. Carboncllii, Iorce (divisolobum Carbonell, Jones). Raised by the late Mr. Carbonell. A handsome las form. $2 S \times 6$ inches.

3. Crawfordianum, Phillips (proliferum Crawfordianum, Jonles). Found in Crawford Park by Mr. W. H. Phillips. J.cngth, a feet.

4. crista, Lnave. Raised in 1886 , by the late Colonel Jones. A dwarf imbricate varicty; with close, dense, cock"s-comb-like crests. $6 \times 2$ inches.

5. cristatum, Lowe (divisolobum cristatum Ivery; W illaston). Ratised in r 870 , by Messrs. Ivery. A grand fern; heavily crested on lower half of frond. $22 \times S$ inches.

6. decorum, Lowe (divisolobum decorum, foncs). Raised by the late Colonel Jones. $32 \times 10$ inches.

7. deltoidcum, Low' (divisolobum-deltoideum, Jom:s). Jax. $33 \times 10$ inches.

S. dumetum, Lore. Raised in I\$S6 by the late Colonel Jones. Upper half of pinne branching in a bush-like manner. Costa splitting near the apex. $13 X+$ inches.

9. clumosum, Lote. Raised in 1886 by the late Colnnd Jones. $\Lambda$ clwarf, broad, bunch-crested form. $\Lambda$ small tasselled head. $9 \times 6$ inclies. 
ro. elegans, Lowe (divisolnbum elegans, Jones).

I I. falcatum, Loave (divisolobum falcatum Moly, Stansfield; and divisolobum laxum Moly, IVollcrston). Remarkably lax and falcate, both in the pinne and pinnules. Pinne, shaped like a reaping sickle, 7 inches long, whilst the frond is only 7 inclıes wide. $22 \times 7$ inches.

12. foliosum, Lowe (divisolobum foliosum Pearson, Jones). Raised by Messis. Pearson. A foliose divisolobe.

13. grande, Lowe (divisolobum grande, Jones). Raised by the late Colonel Jones. A well-merited name. $21 \times 13$ inches.

It. grandiceps, Lowe (divisolobum grandiceps, Jones). Raised by the late Mr. Carbonell. A very fine variety.

I 5. Henleya, Moore (divisolobum proliferum Bagg, Wollaston). Found in 1869 , in Somerset, by the late Mrs. Henley's gardener ( $J$. Bagg). $24 \times 8$ inches.

I6. Holeanx, Moore (divisolobum proliferum Plimsoll, IVollaston). Found in 186r, in South Devon, by Mrs. Hole's gardener ( $\mathrm{J}$. Plimsoll). Very close-growing; widest at base. $20 \times 9$ inches.

17. Jonesii, Lorve (divisolobum Jones, Jones). Found neal Sudbury by the late Colonel Jones. A majestic fern. $36 \times 10$ inches.

18. laxum, Lorve (divisolobum laxum, Jones). Found in 1874 , in South Devon, by the late Mr. J. Wills. A grand form. Pinnules somewhat depauperate at the base of the pinnæ. $30 \times 12$ inches.

I9. longipinnatum, Lowe (divisolobum longipinnatum, Jones). Raised by the Iate Mr. Carbonell. A lax and very graceful ferm, with very long inferior pinnules. $32 \times 12$ inches.

20. Molyi, Lowe (divisolobum Moly, Wollaston). Found in I 875, in South Devon, by Mr. Moly. Plumose. Divisions thin. $24 \times 7$ inches.

21. multifidum, Lowe (divisolobum-multifium, Jones). Raised by the late Colonel Jones. Basal half and apex of trond crested. Frond tapering. Pinne acutilobe at the base, broader above. i $\delta \times 9$ inches (at base).

22. Padleyi, Lowe (divisolobum Padley, Jones). Found in IS66, in North Devon, by the late Rev. C. Padley. One of the finest of the lax forms. $34 \times 10$ inches.

23. perfectum, Lowe (divisolobum perfectum, Jones). Raised by the late Colonel Joncs.

24. Phillipsii, Lorve (divisolobum laxum Phillips, Jones). Found at Castlecoole by Mr. IV. H. Phillips. A fine fern; broadest at the base, and narrowing to the apex. $30 \times$ in 3 inches (at the base).

25. plenum, Lorve (divisolobum plenum, Jones). Raised by the late Colonel Jones.

26. polydactylum, Lowe (divisolobum polydactylum, Jones). Raised by the late Colonel Jones. A cross between Henley:e and polydactylum. $2 \mathrm{I} \times 5$ inches.

27. robustum, Lowe (divisolobum robustum Moly, Jones). Found in 1874 , in South Devon, by Mr. J. Moly. A grand, robust form. $36 \times 16$ inches.
28. Seymourx, 
Found in 1870 , in South Devon, by the late Miss Seymour. A dense form. $18 \times 7$ inches.

29. Stansfieldii, Lowe (divisolobum densum Stansfield, Jones). Raised by Messrs. F. W. and H. Stansfield, at Sale. Somewhat resembling the plumose dirisolobes.

30. stipula, Lonve (divisolobum stipulatum, Jones). Raised by the late Mr. Carbonell, from spores given him by the late Colonel Jones.

31. IVillsii, Lowe (divisolobum IVills No. 3, Jones). Found by the late Mr. Wills, as recorded by the late Colonel Jones.

\section{Section $\delta . \quad$ PLUMOSO-DIVISOLOBUM.}

(Like divisolobum, but with greatly increased development of leafy part of frond.)

*1. Baldwini, Lowe. Raised by the late Colonel Jones, about 1885, from a bulbil of "densum," and given whilst young to Mr. Jolin Loraine Baldwin. The finest of all the plumose divisolobums. Costa of the pinna very thin, and the pinne imbricate; quadripinnate. The divisions finer and more featler-like than any other variety. $22 \times 8$ inches. Colonel Jones's greatest achievement.

*2. densum, Lowe (plumoso-divisolobum densum, Jones). Raised in 1878 by Mr. E. F. Fox from spores of decompositum splendens given hin by Colonel Jones. Length, 24 inches. A mossy mass of foliage. Todea-like in appearance. Sterile, but bulbiferous. Quadripinnate and plumose.

3. dissectum, Pearson. A very finely-cut variety. Raised by Mr. P'earson.

4. grande, Lowe (plumoso-divisolobum grande, Jones). Raised in 1885 by Mr. E. F. Fox. A cross between decompositum-splendens and plumosum of Wollaston. Far supcrior to the parent plumosum. [Mr. Fox has a large number of forms not yet named from this batch of seedlings.]

* 5. imbricatum, Lozve. Raised about 1885 , from a bulbil of "densum." Exceedingly imbricated and plumose. Baldaini and imbricatum were considered two of the most notable varicties at the Royal Horticultural Society's Fern Show, on July 22 and 23 , 1890.

6. laxum, Lorve (plumoso-divisolobum laxum, Jones). Raised in the same batch of seedlings with densum and robustum by $\mathrm{Mr}$. E. F. Fox. Length, 24 inches. Quadripinnate; and more lax than "ensum or robustum. Sterile, but copiously bulbiferous.

7. I'earsoni, Lowe. Divisolobum plumosum Pearson, Jones. A good plumose form.

\$. robustum, lozic (plumoso-divisolobum robustum, fones). Raised by Mr. E. F. Fox. Not as luxuriant or so finely divided as densum. I'inna somewhat curt and rouncled. Sterile, and rery sparely bulbiferous. 


\section{Section $\epsilon$. MULTILOBUM.}

(Pinnules divided into rounded lobes.)

I. Aireyi, Barnes. Found in 1873 , in Dale Park, by Mr. T. Airey. A fine deltoid form.

*2. ariprepes, Lozve. A very graceful large fern. Frond equal in width for the lower half, and then gradually narrowing to a point. $33 \times 7$ inclues. A somewhat similar variety (multilobumLowei) was also raised at Highfield House.

3. attenuatum, Lozve (attenuato-multilobum, Moly). $20 \times 8$ inches A very fine tripinnate form, the pinnulets being very finely cut and divided.

4. conspicuilobum, Padley. Found in Somerset by Colonel Jones in 1878. Length, I foot 6 inches. Mr. Padley has found even finer forms.

5. cristatum, Lorve (multilobum cristatum Jones, Wollaston). Raised in 1873 by the late Colonel Jones. Heavily crested. $24 \times$ 5 inches.

6. decorum, Lozere. Raised by myself in 1876. A large narrow form. $36 \times 4$ inches.

7. deltoideum, Lorve (multilobum deltoideum, Jones). $24 \times 8$ inches. A fine form.

8. densum, Lorve (multilobum densum, Jones). Raised by the late Mr. Carbonell.

9. gracile, Lowe. Raised by the late Colonel Jones. Partly polydactylous.

10. Iona, Lowe (nuttilobum Jones Iona, Jones). Raised by the late Colonel Jones. $26 \times 9$ inches. A fine form.

I I. Jonesii, Lowe (conspicuilobum Jones No. 2, Jones). Found in 1878 , in Somerset, by the late Colonel Jones. Much smaller pinnules than in Willsib, and ending in a sharp point. $18 \times 5$ inches.

12. laxum, Lowe (multilobum-laxum, Jones). Found in 1872 , at Teignmouth, by the late Colonel Jones.

13. lineare, Lowe. Raised by Mr. E. F. Fox from attenuatomultilobum of Moly. Very handsome, and lineare-looking form. $16 \times 6 \frac{1}{2}$ inches. Although pinnæe crowded, pinnules so narrow as to give a lax appearance.

14. multilobum, Lozere (multilobum Gray, Wollaston). Found in 1865 , in S. Devon, by the late Mr. R. J. Gray. Foliose. $30 \times 9$ inches.

15. multilobum minor, Lowe (multilobum Jones, Wollaston). Found in $187+$ in Hants, by the late Colonel Jones. $20 \times 5$ inches.

16. ovale, Lorve (nultilobum ovale Padley, Wollaston). Found in 1863 , in Somerset, by the late Rev. C. Padley. Robust, lax, and elegant. $26 \times 9$ inches.

17. polydactylum, Loree (multilobum polydactylum, Jones). Raised by Mr. E. F. Fox. $30 \times$ I 7 inches. A dense, divisilobumlooking form. Pinne with polydactylous ends.

18. tripinnatum, Moore. Found at Penzance by Mr. R. Tracey Millett. $27 \times 5$ inches. Pinne horizontal (like steps), and pinnules 
rery conspicuously dentate. Totally distinct from Mr. Gillett's tripinnatum, which is a form of decompositum.

19. venustum, Moore (multilobum, IVollaston). Found in Devon by the late Rev. C. Padley. Length, 2 feet. A very handsome multilobe.

20. IVillsii, Lowe (conspicuilobum Vills, Wollaston). Found in 1873 , in Dorset, by the late Mr. J. Wills. $27 \times 10$ inches (in centre of frond). Lax, the lobes being very conspicuous.

\section{Group IV. Heteromorphum.}

(Alteration in contour and margin, clc., of ultimate segments.) Section a. ROTUNDATUM. (Rounded pinnules.)

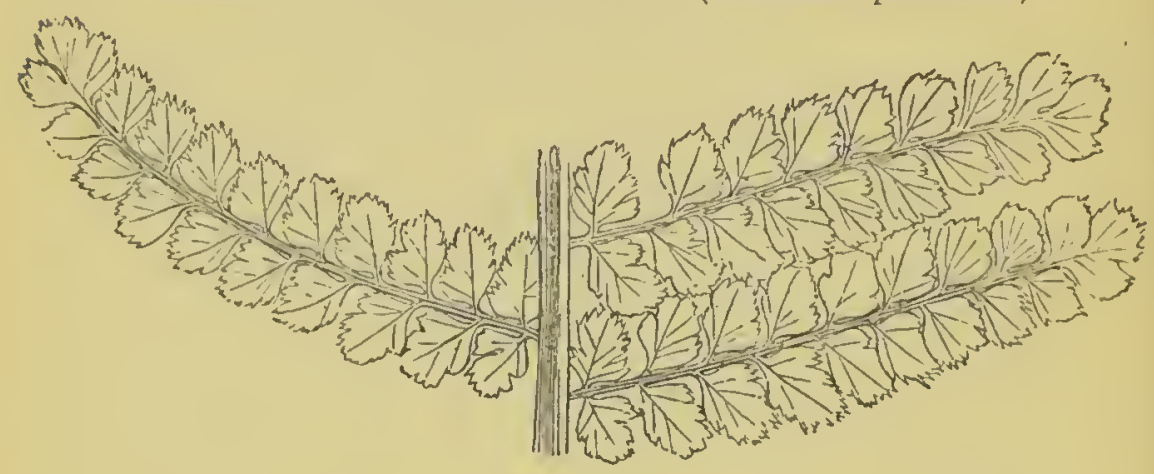

Fis. 36.-Aspidium angulare, var. rotundatum. Portion of frond.

I. angustior, Lowe. Raised from spores. Dwarf. $8 \times 0_{2}^{1}$ inches.

2. capitatum, fozele. A subrotundate form. Raised by myself. I $X_{3}$ inches. A well-branched capitate head, 4 inches long.

3. conchatum, Moore. Found at Hawkhurst by Mr. Moly. Very distinct. Pinnules like shells. $16 \times 3 \frac{1}{2}$ inches.

*4. cruciatum, lozee (rotundato-cruciatum, Jomes). A cruciate narrow form. Raised by myself from spores. $22 \times 1$ inches. Everywhere cruciate; and pinne longer at upper part of frond than Hankeyi.

5. diversum, Lowee. Raised by myself (between rotundatum and cruciatum). $12 \times 2 \frac{1}{2}$ inclies below, where nomal; narowing above to I inch, where cruciate.

*6. erectum, Londe (rotundato-erectum, Jones). Narrow, erect, lax, and attenuated. Raised from spores. I'innules crenate. Pinnac confluent neat the apcx. $2+4 \times 4 \frac{1}{2}$ inches.

7. Gomanstownense, Eore'. Found at Commanstown, County Meath, by Mr. WV. H. Whillips. $12 \times 3 \frac{1}{2}$ inches. A foliose rotundatum.

8. Hankeyi, Loree (rotundato-cruciatum, Jhonker). Raised in I 875 by $M l$. W. Barnarel Hankey. Cruciate from the lase upwards. $20 \times 1$ inches. [lato-cuciatum is not unlike this form, 
but on a much larger scale; and the lobes are divided to the costa at the base of the pinnze; and they are broad, deeply crenate, and confluent above.]

9. Hodgsona, Lowe (rotundatum Hodgsonx, Barnes). Found in 1870 , at Leece, mear Ulverston, by Mrs. Hodgson. Distinct and beautiful. Pinnules lax, thin, and round.

* Io. lato-cruciatum, Lorve. Raised by myself. $23 \times \mathrm{I} \frac{1}{2}$ inches. (var. cruciatum $x$ rotundatum.) Pinnze cruciate and confluent. Only the basal lobe divided. A most distinct fern.

II. laxum, Lowe (rotundatum laxum, Jones. In the late Colonel Jones's collection.

I2. Ligonielense, Lowe. Found at Ligoniel, Co. Antrim, by Mr. IV. H. Phillips. $27 \times 6 \frac{1}{2}$ inches. An interesting subrotund form.

13. Phillipsii, Lorve (rotundatum Phillips, Jones). Found in IS77, in County Down, by Mr. W. H. Phillips. Pinnules smaller and more numerous than in No. I4. Frond widest in the centre, narrowing to a pointed apex. $15 \times 2 \frac{1}{1}$ inches.

14. rotundatum, Moore. Found in 1860 , in Somerset, by the late Mr. Elworthy. $20 \times 2$ inches. A narrow fern, with only two to four pairs of pinnules, which are rounded.

I 5. singulare, Lowe. Raised by myself. I $5 \times 2$ inches. Pinnze ascending. Tips confluent. Apex of frond as if bitten off.

\section{Section $\beta$. LINEARE.}

(Pinnules narrow, supra-lineate or infra-lineate.)

I. confluens, Foot. A lineare form found in Ireland by Mr. S. Foot; and in S. Devon, in I 873 , by Mr. J. Moly. Length, i 8 inches. The ends of the pinne and frond confluent. A lax variety.

2. cuneatum, Wollaston. Found in 1873 in S. Deron by Mr. J. Moly. $2+\times 6$ inches. Lax, with broader pinnules than in lineare.

3. depauperatum, Padlcy. Found by Mr. Padley. I $6 \times 5$ inches. A depauperate lineare.

4. egenum, Lowe (confluens Moly, Jones). Found at Axminster by Mr. Moly. A very depauperate lineare. $24 \times 6$ inches.

5. extremum, Lowe. A very extreme form (frond without label in the late Colonel Jones's collection). Lax ; much depauperate ; and the apices of the pinne confluent and linear. $30 \times 7$ inches.

6. gracile, Wollaston (acuto-incisum, Jones). Found in i 856 in S. Devon by Mr. G. B. Wollaston. A beautiful, symmetrical, acute, incised form, not unlike confluens. $20 \times 6$ inches.

7. gracile-interruptum, Lorve. Found in Somerset by the late Mr. Elworthy. Nearer MIr. Foot's confluens than lineare; the three pairs of basal pinnules wanting; on the upper half of the frond the superior basal pinnule is narrow and very long; beyond which again wanting or depauperate. $24 \times 5$ inches.

8. hirondelle, Wills. Found by Mr. Wills, small but very symmetrical.

9. Jamesii, Lowe (lineare James, Jones). Pinne not so lax, and pinnules broader. Found in Guernsey. 
ro. laxum, Lorve (lineare-laxum, Lorve). Pinnules mostly reduced to a mere fertile thorn. The pinne confluent towards the apex. Raised from spores at Highfield House. $30 \times 7$ inches.

II. lineare, lloore. Larger and more decidedly bipinnate than confluens. Found in Devon by the late Mr. C. Jackson.

12. Molyi, Lowe (lincatum, Moly). Found in S. Devon, in 1873 , by Mr. J. Moly. Fronds, dark-green. Ends of pinnæe confluent. $24 \times 6 \frac{1}{2}$ inches. A fine form.

*I3. nidum, Lowe. Raised by myself in $1863.15 \times 5$ inches. Not unlike confluens, but growing like Asplenium-nidus.

I4. polydactylum, Lowe (lineare polydactylum, Jones). Raised by the late Colonel Jones. $20 \times 6$ inches. A fine form.

15. remoto-decurrens, Wollaston. Found in 1863 , in S. Devon, by the late Rev. C. Padley. $22 \times 5$ inches. Like a broad pinnuled confuens. Thorny.

16. Taitii, Lowe (lineare Tait, Jones). Found by Mr. Tait twenty years ago. A fine lineare, in the style of Jamesii.

17. Willsii, Lowe (lineare Wills, Wollaston). Found in Somerset in $187 \mathrm{I}$. $19 \times 6$ inches. A fine form, without the usual depauperation of lineare. Pinnules lobed.

\section{Section $\gamma$. LACINIATUM. (Laciniate forms.)}

* I. Bucklex, Lowe. A very pretty regular though depauperate fern. Pinnules very small. Pinne varying in length; some attcnuate and some truncate. The apex of the frond usually finely attenuate. $18 \times 4$ inches.

2. Carbonellii, Iowe (grandidens Carbonell, Jones). Raised by the late Mr. Carbonell. A symmetrical laciniatc varicty. I $6 \times 4 \frac{1}{2}$ inclies.

3. caudatum, Lorve (interruptum caudatum, Jomes). Raised by the late Colonel Jones (crucipinnulum + polydactylum) a polydactylous crucipinnulum with a caudate apex.

4. clavapinnulum; Lowe. Found by Mr. Moly. Club-like. Very depauperate. $21 \times 5$ inches.

5. Crawfordianum, Lowe (truncatum, Prageger). Found in 1886 , in Crawfordsburn, by Mr. Praeger. $10 \times 5$ inches. Ending abruptly.

6. deficiens, Wollaston. Found in 1874 , in Dorset, by Mr. John Wills. An extraordinary fern, with deficient pinnules, mostly wanting about an inch from the apex of the pinne, where only points remain. Least deficient near the base of the pinna:. $21 \times 7$ inches.

7. Fittii, Lowe (grandidens Fitt, Jones). A rery distinct crisp form with dark-green fronds, raised by Mr. Fitt. $10 \times 3$ inches.

*S. flabellipinnulum, fones (cristipinnulum, Ifills). Found in 1878 , in Dorset, by the late Mr. Wills. The pinnules fan-shaped. $20 \times 4 \frac{1}{5}$ inches.

9. Foxii, Lorie. Raised by Mr. E. F. Fox (a cross between grandidens and Jacksoni) in 1872 . $10 \times 5$ incles. It is a grandidens to the apices of the pinna, and then a cristato-gracile. 
IO. Glenarmense, Lowe (interruptum Glenarm, Proger). Found in I 884, in Glenarm, by Mr. Praeger. $20 \times 5$ inches. Not much depauperated. Very thorny. [A second form, found in the same place, is distinctly tripinnate. I $3 \times 4 \frac{1}{2}$ inches.]

II. gracile, Lowe. A gracile-like intcrmptum. Found at Ballymeux by Mr. IV. H. Phillips.

12. grandidens, Wollaston. Found in 1872 in Dorset by Mr. J. Wills. Everywhere depauperate. $20 \times$ I inches. A number of kindred forms have been found.

I3. interrupto-caudatum, Praeger. Found in 1885 , in Glenarm, by Mr. Pracger: $2 I \times 7$ inches (at base); only an inch in upper half of frond.

I4. interruptum, Wollaston. Found in Hampshire, in I S62, by Mr. Rake. Length, I $S$ inches. A most interrupted form; some pinnæ 4 inches long, others not $\frac{1}{2}$ an inch; most of the pinne are not an inch in length.

15. irregulare, Jones. Found at Ballymenoch by Mr. WV. H. Phillips. $12 \times 1$ inches. Much depauperated and truncate.

I6. laciniatum, Wollaston. A form of interruptum.

17. Lowei, Lozve (guandidens Lowei, Moore). Very dwarf and fine-cut, the pinnules being acutilobe. Truncate. Length, 4 to 6 inches.

I8. magnum, Lowe. A giant amongst laciniatums. Found at Mequale Bramel, Co. Down, by Mr. W. H. Phillips. $30 \times 7$ inches.

I 9. manica-infanta, Wollaston. Pinnules contracted like a baby's sleeve. Found at Offwell, Devon, by Mr. Moly. $\mathrm{I}_{3} \times 4$ inches.

20. Phillipsii, Lowe (interruptum Phillips, IVolluston). Found in 1876 , in Co. Down, by Mr. W. H. Phillips. $24 \times 7$ inches. Towards the apex pinnæe suddenly shortened; pinnules much depauperated ; lax. General outline of frond symmetrical.

$2 \mathrm{I}$. Praegeri, Lowe (grandidens Pracger). Found in $\mathrm{I} 8 \mathrm{~S} \mathrm{I}$, in Graigavad, by Mr. Praeger. $20 \times 2 \frac{1}{2}$ inches. A bold, truncate grandidens.

22. præmorsum, Allitim Found in Ireland, in 1853 , by Dr. Allchin, and subsequently in Devon and Haxts. Dwarf, narrow, præmorse variety. I $4 \times 3 \frac{1}{2}$ inches. Mr. IV. H. Phillips found a form at Knock, $24 \times 4 \frac{1}{2}$ inches.

23. Strictum, Jones (interruptum, Bumes). A good form.

24. Thompsoni, Lorve (grandiceps Thompson, Jones). A curious very narrow grandiceps; with abrupt pinne, and with larger confluent ones. $14 \times \mathrm{I}$ inches. A slender laciniate head, 2 inches wide. Distinct.

25. truncatun, Lowe (grandidens truncatum Elworthy, IVollaston). Found in I 859, in Somerset, by the late Mr. Elworthy. Pinnze and apex truncate ; pinnules very abnormal. $7 \times 1 \frac{1}{2}$ inches.

\section{Section $\delta$. SETOSUM. (Pinnules thorny.)}

I. cristatum, Lowe (setoso-cristatum, Moore). Found in 1874 , in S. Devon, by Mr. J. Moly. Apex of pinne slightly crested, and a compact, nuch-branched head, not wider than the frond. This 
charming variety has the margins of the pinnules crowded with bristles. $20 \times 5 \frac{1}{2}$ inches.

2. cuneatum, Lowe (setoso-cuneatum, Jones). Found in 1877 , in Co. Antrim, by Mr. IV. H. Phillips. A delicate, pale, lustrous green ; and so copiously dentate as to resemble Kalothrix of the Lady Fern. $16 \times 4$ inches. A grand form. Mr. Moly found a similar plant, but whether exile 1 ain unable to say.

3. exile, Wollaston.

4. gracile, Lowe (Setoso-gracile, Phillips). Found at Castlecoole by Mr. IV. H. Phillips. $20 \times 5 \frac{1}{2}$ inches. A neat form.

5. inzequale, Lowe (inzequale Setosum, Phillips). Found in Glen Deris by Mr. W. H. Phillips. $16 \times 3$ inches.

6. Kalothrix, Lozer. Found at Shute, Devon, by Mr. Moly. A grood form. $20 \times 5 \frac{1}{2}$ inches.

7. Phillipsii, Lowe (cxile Phillips, Jones). Found at Holywood, Co. Down, by Mr. WV. H. Phillips.

\section{Section $\epsilon$. PERSERRATUM.}

(Pinnules deeply and acutely serrated.)

1. Bayliae, Mocre. An interesting dwarf form. $I_{4} \times_{4}$ inches.

2. Carbonellii, Lorue (perserratum Carbonell, Jones). Found by the late Mr. W. C. Carbonell in Monmouth. Dwarfer than Baylize.

3. fisso-decurrens, Wollaston. Found in 1874, in Dorset, by Mr. Moly. Narrow and branching at the base into twin fronds. $19 \times 23$ inches.

4. Pateyi, Lowe (perserratum Patey, Wollastonz). Found in 1873 , in Berkshire, by Mr. G. S. Patcy. A larger fern than perserratum, with very much larger pinnules. Dark green. $23 \times 6 \frac{1}{2}$ inches.

5. perserratum, IVollaston. Found in 1869 , in South Devon, by Mr. G. B. Wollaston. $20 \times 6$ inches. A very Lady-Fern-looking plant. Dark green.

\section{Division C.}

ALTERATION IN OUTLINE OF FROND.

(The relations of hard and soft parts remaining unchanged.)

\section{Group I. Widened.}

Section a. DELTOIDEUM. (Deltoid.)

I. curtum, Moore. Found near Nettlecombe by Mr. Elwortly: Lengrth, 8 inches. Pinna crowded, overlapping. Plumose-like.

2. decompositum, Lowe (deltoideo-decompositum, Moly). Found in I 874, in Devon, by Mr. J. Moly. 2 I $\times 9$ inclies; middle of trond 6 inches wide; basal pinne much larger.

3. decurens, Lote' (deltoiden-decurrens, IIollaston). Found in I $\$ 76$, in Dorset, by Mr. G. B. Wollaston. $22 \times 6 \pm$ inclies. Coriaceous; pimnules lirge.

4. foliosum, Lotie (deltoideo-foliosum, Jonts). Found in 1875, in Devon, by Mr. Moly. $2+\times 6$ inches. A foliose, coriaceous form.

5. latipes, Moore. Kaised in I 870 by Mr. l'arsons. A tine deloid 
form. $27 \times 9$ inches. The late Mr. Elworthy, in 1854 , found a very similar fern.

6. plumosum, Lowe (deltoideo-plumosum, Moly). Found in Dorset by. Mr. J. Moly. Length, 2 ft. 3 inches.

7. proliferum, Lowe (curto-proliferum, Wollaston). Found in I 863, at Cunsey (Lake district), by Mr. J. A. Wilson. Narrow, and bulb-bearing.

\section{Group II. Narrowed.}

Section a. ANGUSTATUM. (Frond simply narrowed.)

I. Padleyi, Lowe. A narrow, very lax, slender form, with an acute apex. Found in Somerset by myself in 1864 .

2. Phillipsii, Lozve. A narrow form, found at Castlereagh by Mr. W. H. Phillips. $7 \times 2 \frac{1}{1}$ inches. Pinnules subrotund.

3. ramo-cristatum, Padley. Found in $186_{3}$ by the late Rev. C. Padley. $12 \times 1 \frac{3}{4}$ inches. Pinnæe confluent and dilate. Apex of frond crested.

4. subimbricatum, Lowe (interruptum, Phillips). Found at Springfield by Mr. W. H. Phillips. $15 \times 2 \frac{1}{2}$ inches.

\section{DIVISION D. \\ ALTERATION IN THE COLOUR OF FROND.}

\section{Group I. Variegated.}

Section $a$. VARIEGATUM.

I aureolum, Lowe. Found at Martin Hoe, Devon, by myself, in I885. Narrow, pinnules imbricate at the base of the pinnz; apex of the frond branching. An autumnal golden hue. $24 \times 5$ inches.

2. aureum, Jones. Found by the late Colonel Jones.

3. inæquale, Poulley (inæquale variegatum Padley, Wollaston). Found by the late Rev. C. Padley. Pinnules (not pinnx) depauperate. $24 \times 6$ inches.

4. Jonesii, Lowe (variegatum, Jones). Found by the late Colonel Jones. Mr. Moly has also found a similar one.

5. leucothea, Lowe. A large fern in Colonel Jones's collection, some fronds entirely white, and others well variegated. $31 \times 7$ inches.

6. multifidum, Lowe (inaquale variegatum multifidum, Jones). Tips of pinnze confluent and slightly crested. A depauperate form. $22 \times 8$ inches.

*7. polydactylum, Lowe (inaquale variegatum polydactylum, Jones). Raised by the late Colonel Jones. A cross between No. 3 and polydactylum grande. Some pinnules very large, others all but wanting. A grand variegatum. $36 \times 8$ inches.

8. pulcherrimum, Lowe (pulcherinum variegatum Moly, Jones). Found by Mr. Moly. A variegated pulcherrimum. $28 \times 8$ inches. A charming variety, with rich golden variegation.

9. venosum, Padley (venoso-variegatum, Jones). Found by the late Rev. C. Padley. 
I2S BRITISH FERNS.-SUB-ORDER II. TRIBE IO.

THE MARSH FERN.

NEPHRODIUM THELYPTERIS.-Destaux.

(L.ISTREA THELTPTERIS.-BOr'\%.)

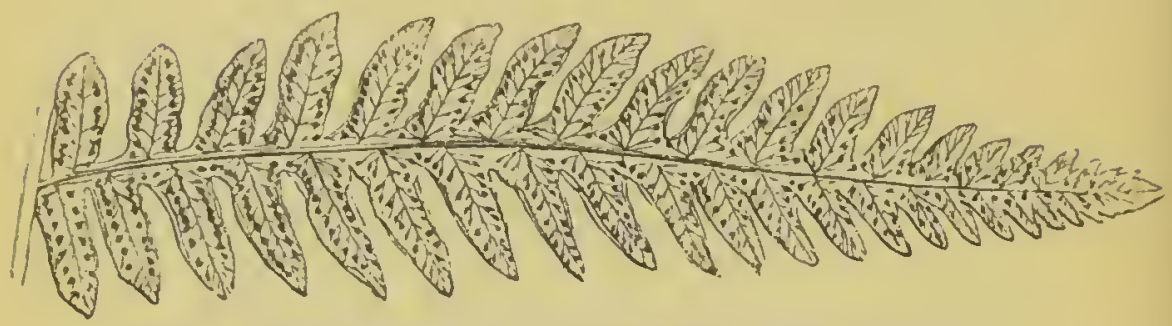

HIG. 37.-Pinna (showing fructification of Nephrodium thelypteris).

AN interesting fern, the associate of Osmunda regalis in boggy situations. It is readily cultivated, but prefers wet peat, as water is its especial requisite. The fronds vary from 6 inches to 4 feet, including the stem; for at least half the frond is the naked stem. It is crect, and the fronds are of a delicate pale-green. Deciduous; rhizoma creeping. Quite distinct from all other species. Widely spread, but very local. It is found in Devon, Somerset, Hampshire, the Isle of Wight, Sussex, Kent, Surrey, Berkshire, Essex, Norfolk, Suffolk, Cambridge, Bedford, Huntingdon, IVarwick, Stafford, Hereford, Salop, Nottingham, Yorkshire, Cheshire, Westmoreland, Cumberland, and Northumberland In WalesGlamorgass, Pcmbroke, Carnarvon, and Anglesea. In ScotlandForfar; Shetland. In Ireland-Antrim, Galway, Mayo, Wicklow; and Kery.

Occurs throughout Europe; in North America; and Nortl Africa.

'There are no varieties.

THE MOUNTAIN ISUCKLER FERN.

Nephrodium montanum.-Bakir.

(L.ISTRLA MONTANA.-.WeORe.)

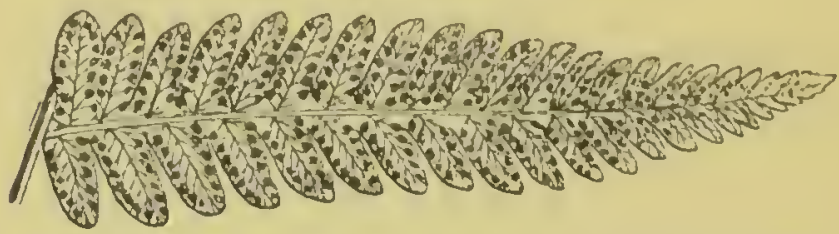

FIG. 38.-Nephrodium montauum. Punna (showing fructification).

KNOWN as the "Sweet Mountain Fern," owing to the strong yet pleasant scent of the fronds. Although recognised as a mountain fern, it is nevertheless found from the sea-level to an altitude of 
about 3,000 feet. Usually an inhabitant of hillsides, especially in mountain districts; luxuriating in strong soil in damp situations. An easily recognised species, with lanceolate, pinnate fronds. Sori marginal. Fronds varying from I to more than 3 feet in length, and from 2 inches to nearly a foot in width. Erect in habit. A deciduous fern, requiring a damp situation for successful cultivation. A common species in this country, and found throughout Europe. Of late years a number of varieties have been discovered, the late Mr. Barnes, of Milnthorpe, being the most successful discoverer as well as cultivator.

\section{VARIETIES.}

I. abruptum, Moore. An interesting variety, found at Barnstaple by the late Mr. C. Jackson. Pinnxe narrow and short, pinnules interrupted.

2. albo-variegatum, Barnes. Found in 1872 , in Wastdale, by Mr. J. M. Barnes. Fronds green and white.

3. angustifrons, Wollaston. Fonnd in Patterdale by Mr. G. Whitwell. lake.

4. angustum, Wollaston. Found at Staveley by Mr. J. West-

5. apuxforme, Moore. Found in 1865, in Swindale, by Mr. J. M. Barnes. Apex of frond many branched.

6. attenuato-cristatum, Moore. Found in 1865 , in Mardale, by Mr.J. M. Barnes. A handsome robust form, with caudate and crested fronds.

7. Barnesii, Monre (adpressa, Wollaston). Found in 1865 , in Swindale, by Mr. J. M. Barnes. A grand, bold, dark-green variety, with erect fronds which are very narrow; pinnules horizontal. Length, 26 inches ; width (at widest), only $2 \frac{1}{2}$ inches.

8. Bellii, Lowe (crispum Bell, Barnes). Found at Coniston by Mr. Bell.

9. Boydii, Lowe (plumosum Boyd, Bames). Length, I $\frac{1}{2}$ feet.

Io. brevilobum, Moore. Found in 1864 , in Mardale. A distinct and beautiful form, with pinnules evenly reduced.

I I. caudato-cristatum, Barnes. Found in I863, at Rydal Head, by Mr. Crouch. Robust; very caudate. Small crests.

12. caudatum, Moore. Found in I 868 , in Mardale and Wastdale, by the late Mr. J. K. Hodgson. The frond and pinnæe conspicuously caudate.

I3. Clowesii, Lowe. Found near Windermere by Mr. J. Huddart. Pinnæ digitate ; apex of frond crested.

I4. concinnatum, Barnes. Found in I 866, on Loughrigg, by Mr. IV. Crouch. An interesting variety, the points of the pinnce like ringlets.

I5. congestum, Barnes. Found in I873, in Langdale, by Mr. J. M. Barmes. A fine variety; densely foliose.

16. coronans, Hoore. Found in 1872 , in Langdale, by Mr. J. M. Barnes. The best heavily crested variety. Length, I $\frac{1}{2}$ feet. 
17. corymbiferum, Whitwell. Found at Grasmere by Mr. J. Garnett.

IS. crispatissimum, Wollaston. Found in 187 I, in Langdale, by Mr. J. A. Wilson, and since in Troutbeck by Mr. J. Gott. Pinmules undulated.

19. crispatum, Jones. Found at Clougha by Mr. J. Stewartson.

20. crispo-angustatum, Barmes. Found in Patterdale by Mr. IV. Foster.

2I. crispo-congestum, Burnes. Found at Coniston by MIr.J. MI. Barnes, junr.

22. crispum, Moore. Found in 1865 , in Furness Fell, by Mr. J. M. Barnes. Previously it had been found on the Clova Mountains by Dr. Balfour. A striking variety, with undulate pinnules.

23. cristato-angustatum, Moore: Raised by Mr. J. M. Barnes. A narrow, wonderfully crested variety.

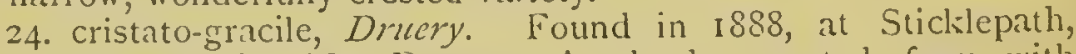
North Devon, by Mr. Druery. A slender crested form with narrow pinna.

25. cristatum, Wollaston. Found in 1871 , in Westmorcland, by Mr. J. M. Barnes. A grand crested variety. Length, 24 inches; widtl, 6 inches; a small capitate head. A form of cristatum was found in Monmouthshire by Mr. T. H. Thomas.

26. Crouchii, Lowe. Found near Tain, N.B., in IS77. An interrupted form.

27. curtum, Bames. Found in Wyresdale by Mr. J. Hartley.

28. curvatum, . Moore. Found in 1863 , at Farleton Knot, Westmoreland, by the late Mr. Jacob Jones. Length, 30 inches; width (in middle of frond), $4 \frac{1}{1}$ inches. Pinne curving downwards; and upper half of frond gradually narrowing, to a point. A fine variety.

29. curvatum-Barnesii, Moore. Found in 1866 , in Garsdale, by Mr. J. M. Barnes. A fine robust form with curving-down pinnules. 30. curvatum-Whitwellii, Barnes. Found at Coniston by MIr. G. Whitwell.

31. decurrens, Moore. Found in 1866 , in Garsdale, by Mr. J. M. Barnes. Another robust form; with curving-down pinnas.

32. deficiens, Wollaston. Found in Longsteddale by Mr. G. Whitwell.

33. depaupcratum, Druery. Found in 1888 , at Sticklepati, North I)evon. Dwarf; very depauperate.

34. digitatum, Jones. Found in 1875 , in Langdalc, by Mrs. J. K. Ilodgson. Length, 2 I inches; width, $5 \frac{1}{3}$ inches. Digritate cxcept the apex, which is pointed. Mr. J. Hitrtley hits also found a digitate variety at Coniston.

35. crosum, Hoore. I ound near bowness by Mr. F. Clowes. The pinnules are deformed.

36. flavo-variegatum, birmes. Fonnd in sereral places. Fronds green and jellow.

37. flexuosum, Wollasten. Found in 1870, in Westmoreland, by Mr. W. Crouch. Length, 24 inclies; width (in midelle of trond) $4 \pm$ 
inches; at the base, only I inch wide. Rachis slightly fexuose; pinnae and pinnules much twisted.

38. Fosteri, Lowe (brevilobum Foster, Bames). Found in Patterdale by Mr. IV. Foster. Another brief-lobed variety.

39. furcans, Moore. Found in Westmoreland by Mr. Stansfield. Length, 12 inches; ending in a tuft of spreading segments.

40. furcillatum, Wollaston. Found at Brotherswater and Frostrow, by Mr. G. Whitwell.

4I. Gottii, Lorve (crispatissimum Gott, Hartley). Found at Troutbeck by Mr. J. Gott.

42. grandiceps, Barnes. Raised by Mir. Barnes in 1872 . Length, I 8 inches; width, I inch; the apex capitate and crested, and 4 inches wide.

43. grandiceps-Fosteri, Lowe. Found in Martindale, by Mr. J. J. Smithies.

44. Hodgsonix, Lowe (polydactylum, Barnes). Found in 1875 by Mrs. J. K. Hodgson, in Langdale. Frond and pinna crested.

45. inrequale, Wollaston. Found at Hartsop and Brotherswater by Mr. G. Whitwell.

46. inaquale-acutilobum, Wollaston. Found at Cautley by Mr. G. IVhitwell.

47. inaequale-confluens, Wollaston. Found at Hartsop by Mr. G. Whitwell.

48. incisum, Barnes. Found in 1827 , in Langdale, by Mr. J. M. Barnes. Length, 27 inches; width (in middle of frond), ro inches. Pinna lax; pinnules incised; apex truncate.

49. interrupto-crispum, Bames. Found at Coniston by Mr. G. S. Whitwell.

50. interrupto-laciniatum, Moore. Found in 1872 , in Langdale, by Mr. T. Hartley. Length, I 8 inches; width (in middle), 5 inches. Very irregular; pinnze interrupted, pinnules much depauperated, and apex truncate.

5I. interruptum, Moore. Found in I86I, in Levens Park, by Mr. J. Crossfield. Irregular, with pinnules reduced. More recently found in Co. Antrim by Mr. R. Ll. Praeger.

52. interruptum-Barnesii, Moore. Found in I864, in Westmoreland, by Mr. J. M. Barnes. Length, 20 inches; width (in middle), 7 inches. Depauperate.

53. laciniato-caudatum, Barnes. Found in 1865 , in Mardale, by Mr. J. M. Barnes. Pinnæe and pinnules defective.

54. latifolium, Barnes. Found at Cautley, by Mr. G. Whitwell.

55. lobatum, Moore. Found in I873, in Langdale, by Mr. J. MI. Barnes. A very fine, almost tripinnate form.

56. multifidum, Bames. Found in 1872 , at Seathwaite, by Mr. J. K. Hodgson. An interesting variety, with apex of frond multifid. Mr. J. Stewardson found this also at Clougha.

57. multiforme, Barnes. Found in Garsdale, by Mr. G. Whitwell.

58. muitifurcatum, Wollaston. Found at Coniston by Mr. G. S. rihitwell. 
59. Nowellianum, Moore. Found in North Wales, in I 860 , by Mr. J. Nowell. A distinct form.

6o. plumosum, Barnes. Found in 1876 , at Little Langdale, by Mr. T. Airey. A splendid, finely cut, plumose, sterile form. Mr. G. Whitwell has also found this on Patterfell.

6I. polydactylum, Barnes (cristatum, Moore). Found in I860, by Mr. Clarke, of the Glasgow Botanic Gardens. Mr. J. Stewardson has also found at Clougha a polydactylous form.

62. premorso-cristatum, Wollaston. Found on Patterfell by Mr. G. Whitwell.

63. ramo-coronans, Barnes? Branching and crowned. Length, $1 \frac{1}{2}$ fcet.

64. ramo-cristatum, Barnes. Raised in 1873 , by Mr. Barnes. Length, 16 inches; width, $1 \frac{1}{2}$ inches. Branching, both in the stipes and rachis. Width across the lax head, 5 inches.

65. reflexum, Jones. Found at Coniston by Mr. J. Stewardson.

66. revolvens, Phillips. Found at Newcastle, Co. Down, by Mr. W. H. Phillips.

67. rotundatum, Wollaston. Raised by Mr. Barnes in I872. Length, 22 inches; width, in middle of the frond; 7 inches. Very short rotund pinnules; apex caudate.

68. rugoso-interruptum, Barnes. Found at Coniston by Mr. G. Whitwell.

69. serrulatum, Wollaston. Found at Troutbeck, and another found in Garsdale by Mr. G. Whitwell.

7o. simplex, Moore. Found in 1867 , in Mardale, by Mr. J. M. Barnes. Mr. Barnes remarks, that it closely resembles Polypodium vulgare.

71. Smithiesii, Lowe (grandiceps Smithies, Wollaston). Branching and crowned.

72. strictum, Wollaston. Found at Cautley by Mr. G. Whitwell.

73. subcrispum, Barnes. Found in 1873 , in Wastdale, by Mrs. J. K. Hodgson. Crispy and undulate.

74. subsimplex, Moore (confluens, Wollaston). Found in 1869, in Westmoreland, by Mr. J. M. Barnes. Length, 20 inches; width at the base, $1 \frac{1}{2}$ inches, and in centre of frond, $6 \frac{1}{2}$ inches. Very confluent.

75. truncatum, Wollaston. Found near Tunbridge Wells by Mr. G. B. Wollaston. Fronds and pinne horned; apex like bitten off.

76. varicgatum, Barnes. Found in 1873 , in Swarthfell, by Mrs. J. K. Hodgson. Fronds variegated with green and ycllow:

77. Whitwellii, Lore (conerestum Whitwell, barmes). Found in Little Langdale by Mr. G. Whitwell. Another form of congestum

The names only of half these varictics are known to the author. 


\section{THE MALE FERN.}

\section{NePHROdIUM FILIX-Mas.-Richard. (LASTREA FILIX-MAS.-Presl.)}

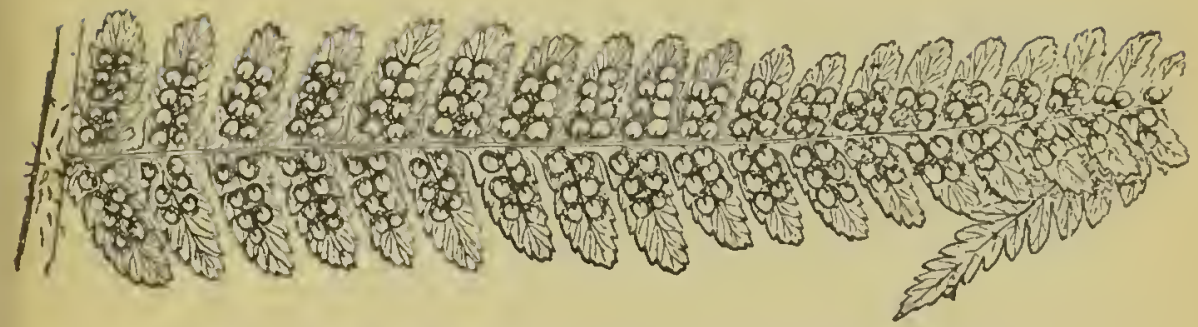

FIG. 39.--Pinna (showing fructification of Nephrodium Filix-mas).

UNDER Presl's Lastrea Filix-mas we have apparently thrce species. They are too distinct, both in their normal forms and in their varieties to enable us to consider them as mere sections, unless we look upon $N$. propinquum as the mountain form of N. paleaceum. As our object is, to produce a Handbook of all the distinct varieties, it has been thought best to follow Wollaston's arrangement.

According to Mr. G. B. Wollaston (who pointed out these distinctions some years ago), we have the following characteristics :-

Froncis and
N. FILIX-NAS.
N. PALEACEUn.*
N. PROPINQUUN. pinne convex.......

Colour .. shining pale green .

Fronds .. partially deciduous

Indusium . not embracing spore cases; evanescent, disrupted

$$
\text { plane ........ concave }
$$

shining deep green. . dull pale green

evergreen or subquite deciduous evergreen

embracing spore cases; persistent, entire embracing spore cases ; persistent, entire

\section{Tcxture of} frond . . papery ...... coriaceous . . . . . soft

Pinnules . saw-toothed. . . . scarcely toothed. . . clouble saw-toothed.

The concave character of the frond is not uncommon on mountains, or when plants grow under difficulties, such as insufficiency of soil, unfavourable climate, etc. This may be seen on Ben Lawers, with the examples of half-starved Polypodium vulgare, P. dryopteris, and P. phegopteris. Diminished size, wavy outline, crisp, and a more or less abnormal and starved-look are features familiar to all mountain Botanists. This is also to be seen with regard to ferns growing on rocks and walls in the Lowlands.

* Lastrca pscudo-mas, Iollaston. There can be no doubt this is the Aspidium paleaceum of older writers, hence its adoption. 
Near Chepstow, except when growing with great luxuriance, the Hart's-tongue is scarcely ever flat-fronded; it is mostly undulate (or wavy), and often crisp. The beautiful form of Harts-tongue, known as crispum, is more abundant in Monmouthshire than in the whole of the rest of the United Kingdom. Within the last few years, not more than half-a-dozen miles from Chepstow, more than fifty plants of "crispum" have been found ; and of these twenty-nine were discovered by the late Colonel Jones, between Caerwent and Shirenewton; whilst on the opposite side of the Wye, near Tidenlam, Major Cowburn has found nineteen, for which refer to section "crispum" in the descriptions of the varieties of Scolopendrium vulgare.

Mr. Wollaston proposed the name, pscudo-mus, for one of these species; but Féc, in "Iconogr. Nouv." uses the same name for Filix-mas, whilst Aspidium paleaceum Don "Prod. Fl. Nepal" has been adopted years ago for var. palcacea, Moore, "NaturePlinted Ferns." (This is the type of the normal form of the subevergieen ferm under discussion, after the present species; and no more appropriate name could be suggested.)

\section{THE MALE FERN.}

\section{NEPHROdIUM Filix-MAS.-Richard.}

THE normal form is large, but less elegant than N. paleaceum; textare of the frond thinner, colour paler and less shining; partially deciduous. The fronds become broken at the ground by itutumnal winds, and lie prostrate, whilst those of $N$. paleaceum retain their erect position until the spring fronds are reacly to unfold. It is a common fern in this country.

\section{VARIETIES.}

1. acrocladon, Lowe. Raised by the late Mr. A. Clapham, of Scarborough. A shicld-fern-looking plant with deep green fronds, which are digitately crested, except towards the apex; the extreme (1) is however crested. Pinnules decply incised. Length of frond, 2 feet.

2. acuto-furcatum, Barnes. Found in 1873 , on Borwick Moor, by Mr. J. Bolton. A neat crested variety with very acute fronds.

3. argenteum, Plitlips. A white variegated varicty, found in Ulster by Mr. IV. H. l'hillips.

4. athyrioides, Lowe. More like the "Lady" than the "Male Ferm." Raised from limerre. A pretty variety, with fromls gradually becoming narrow and cuding in a slomp-pointed tip. limas attenuated at the tips, and occasionally depauperate at the base. Pinnules linear, decply cut, and curving upwards, giving it very dentate appearance. $32 \times 9$ inclies (at base, only $2 \frac{1}{2}$ inches).

5. altenuato-multifidum, Ifollastm. Found in 1564. in Mardite, by Mr. J. M. lianes, of Milnthorpe. A graceful viricty, with narrow finely-cut pinnules.

6. atcenuatum, I'atliy'. Found in $\mathbf{1} S 64$, in North Deron, by the 
late Rev. Charles Padley, of Enville. Pinnze lax; pinnules narrow and sessile, except the basal pair. Frond symmetrical, yet more or less depauperate, the apex of the front most so. $24 \times 9$ inches.

7. Barnesii, Moore (curta, Wollaston). Found at Heversham, in Lancashire, by Mr. J. M. Barnes. A grand, very narrow form. Pinnze elongate-triangular; pinnules broad and conspicuously toothed. $15 \times 2 \frac{1}{2}$ inches.

8. Berryx, Lowe (grandiceps, Berry). Found in 1870 , in North Devon, by Mrs. Berry, and now in the possession of Mr. Gardener of Ilfracombe. A very fine granticeps form, differing in being more thoroughly ramose, and in being often comute. Length, $2 \mathrm{ft}$.

9. Bollandx, Woore (plumosa, Wollaston). Found in 1857 , in Kent, by Mrs. Bolland. A charming plumose, almost barren form. It is partly depauperate, which interferes with its beauty.

10. Clowesii, Moore. Found in I859, at Troutbeck, by Mr. F. Clowes, of Windermere. A robust variety, with frond and pinnæe digitate.

II. confluens, Phillips. Found at Ligoniel, Co. Antrim, by Mr. W. H. Phillips. A fine confluent form. $26 \times 6$ inches.

12. crispatum, Bames (congesta, Wollaston; fluctuosa, Stansfield). Found in I864, at Coniston, by the late Mr. J. K. Hodgson, of Ulverston. A superior variety, with a compact habit and dark-green fronds. Pinnules crisp. $15 \times 6$ inches. Canon Swayne, of Salisbury, gave Colonel Jones a remarkable dwarf crisp form, which he had found in 1874 in Carnarvon; and the Rev. S. A. Brenan also found another in Tyrone.

13. cristatum, Lowe (cristata Crouchii, Bames). Found at Rydal, in I 864 , by Mr. W. Crouch. A very vigorous form, with loose spreading crests.

*I4. Cronkleyense, Lowe. Found in $186_{3}$, in abundance, on Cronkley Fell, near the Falcon Clints, by myself and my brother (the late Colonel Arthur S. H. Lowe, of Gosfield Hall). It has the general appearance of attenuatum, but the pinnules are twice as broad. Many of the pinnae are confuent at their extremities. A somewhat similar form was found by myself near Chaigeley Manor, Lancashire, named Marstena, differing only in not being confluent.

I 5. clecompositum, Allchin. Found in 1871, in South Devon, by Dr. Allchin. A handsome very foliose fern, with broad pinnules, which are toothed and overlapping. Basal pinnules very long. $24 \times$ I I inches.

16. densum, Barnes. Found in $1 \$ 76$, in Patterdale, by Mr. T. Airey. A remarkable congested form.

I7. dentatum, Lowie. Found near Nettlecombe Court, by the Iate Mr. Elworthy. A large-growing, coarsely dentate variety, with fronds 4 feet in length.

* IS. depauperatum, Padley. Found in IS68, on Exmoor, by the late Rev. C. I'adley. A most distinct and interesting variety. Frond widest at the base. I'inna crested. Pinnules depauperate ; most so in the middle of the frond. More or less confluent on the upper third of the frond. $21 \times 5$ inches. 
I9. digitale, Loave (digitatum Barnes, Whitwell). A digitate variety found at Burneside by MIr. J. M. Barnes.

20. digitatum, Lowe (digitata Jonesii, Barncs). Found in IS6o, near Burton (English Lakes), by Mr. J. M. Barnes. A stronggrowing fern, with frond and pinne digitate.

2r. Drueryi, Lowe (polydactylum Druery, Jones). Found in I88t, near Kimarnock, by Mr. C. T. Druery. The tips of the fronds and pinnx broadly flat tasselled. Slightly pendulous from the weight of the tassels. Inconstant. Length, 36 inches.

22. Ellacombei, Loave (cristata Ellacombe, Wollaston). Found in I $\$ ; 6$, in Pembroke, by the late Rev. H. Ellacombe. The finest and most symmetrical of the large crested forms. Pinna close together, long, and compactly tasselled. Frond terminating in a pointed, crested apex. $27 \times$ I I inches.

23. clongatum, Moore. Found in the Isle of Wight by the Rev. IV. H. Hawker and Mr. A. G. More. Large lance-shaped fronds. Pinnæe lax and caudate. Pinnules elongate, narrow, bluntish. A somewhat similar form, clegans, was found near. Whitby by the late Mr. IV. Willison.

24. erosum, Clowe's. Found near Keswick by Miss Wright and at Windermere by Mr. Clowes. Variously erose and irregularly contracted.

25. excurrens, Moore. Found in I862, in Silverdale, by Mr. J. Crossficld, and at Staveley by Mr. J. A. Martindale. The frond and also the pinne terminating with a horn. form

26. fluctuosum, Moore (crispatissima, Wollaston). A crisp, wayy

27. folioso-truncatum, Lowe. No history. From a frond in the late Colonel Jones's collection of dried specimens. A grand, branched, henvy foliose form. Very stiff truncate pinna, only + inches wide at the base. Length, 15 inches.

*28. Gemma, Lowe. Raised by myself in I\$69. An improred "ramosum."

29. gracile, Jones. Raised by the late Colonel A. M. Jones. A very lax, regular, and symmetrical fern. Pinnules broadest at the base of the frond, and also broadest at the base of the pinna: gradually becoming smaller to the pointed apex of the pinne. Length, I foot $S$ inches, breadth, 7 inches.

30. grandiceps, Sim. Found in IS62, on Warton Crag, by a labouring man (Wearing). Stem dividing into twin branches, which again branch several times, producing a large spreading head. Pinnae crested. (A seedling raised from grandicefs at Highfield House, * accetum," Lorve, is more vigorous and his a more sturdy upright growth.)

31. Hodgsona, Lowe (gracile, Barnes). leound in I 873 at Seathwaite. $\Lambda$ different fern has been figured under the name sroucile by Colonel Jones, necessitating the change of name of the Seathwaite variety. A beautiful form, with narrow, fincly cut pinnules.

32. inflexum, Barn's. Found at $A$ mbleside by Mir. J. M. bannes. $\Lambda$ singular bent variety. 
33. interruptum, Moore. Found near Bowness by Mr. Clowes, and at Morecambe Bay by the late Mr. Monkman. A good form was also found in 1874 , at IVindermere, by Mr. T. Airey. Very irregular; most of the pinnules much shortened, and some wanting. 34. Iveryanum, Moore (cristata Martindale, Wollaston). Mr. IV. Martindale found in 1870 , at Vinster, a copy of this crested fern.

35. Jervisii, Moore. Found near Darlaston Hall, Staffordshire, by the late Mr. Swynfen Jervis. A large-growing, coarse, tasselled fern of no great beauty.

36. Jonesii, Lorve (polydactyla Jonesii, Barnes). Found in is6o near Burton (English Lakes) by Mr. J. J. Jones. A graceful crested variety.

37. Kilmoryense, Lozve. Found at Kilmory, Argyleshire by Canon Ellacombe. It is not unlike Bollandce, but more depauperate, and pinnules smaller. $33 \times 8$ inches.

38. lineare, Wollaston. History unknown. Very distinct. Pinnules linear, or wanting, or merely thorn-like. $2 \mathrm{I} \times 6$ inches.

39. multiforme, Barnes (inxquale-furcans, Jones). Found in I $87 \mathrm{I}$, in Lancashire (near Ulverston) by Mr. J. M. Barnes. A more curious than graceful fern, with very broad pinne; mostly polydactylous, some without crestings and shorter, and some wanting. linnules varying, some depauperate; in fact, all manner of forms.

40. Padleyi, Lowe (grandiceps Padley, Jones). Found by the late Rev. C. Padley. A fine grandiceps with a dense bushy habit.

41. platyphyllum, Clapham. Found in I871, in Perthshire, by a gardener (Peter MICDonald). Another polydactylous form, conspicuously crested. Pinnæe approximate, pinnules of one toucling those of the next pinna. Basal pinnules on the lower half of the frond, smaller than the rest ; and slightly crested below the tasselled apex of each pinna ; pinnules almost wanting. $24 \times$ Io inches.

42. polydactylum, Lozere (polydactyla Barnesii, Barnes). Found in I 865 at Whitbarrow by Mr. J. M. Barnes. A very robust crested form. Length, exceeding 3 feet.

43. productum, Moore. Found in I 862, in Silverdale, by Mr. J. Crossfield. Somewhat like the ordinary incisum, with large pinnules.

44. ramosum, Barnes. Found in I875, at Red Bank (English Lakes), by Mr. T. Airey. A fine variety, with ramose, crested fronds.

45. recurvum, Murray. Found in I 889 at Innerwell, Wigton. A striking form, with pinnules recurved nearly into tubes.

46. reticulatum, Birkenhead. Length $\mathrm{I}_{2}^{\frac{1}{2}}$ feet.

47. Ruttledgei, Lozve (cristata Ruttledgei, Barnes). Found in 1872 at Old Hutton. An elegant crested variety.

48. Stewardsona, Lowe (digitata-Stewardsonæ, Bames). Found in 1875 on Lancaster Moor by MIrs. Stewardson. An elegant, vigorous, digitate fern, with broad, short pinnules.

49. tortuosum, Moore (flexuosa, Wollaston). Found in I864, in Dumfries, by Mr. Tod, of Edinburgh. Fronds and pinnee (the latter more especially) flexuose. $20 \times 3$ inches. 
50. variegato-aurcum, Lozve. Found in $\mathrm{I} \delta S_{3}$ at Mlonkton Wylde, Dorset, by Mr. Moly. Normal in form, with a yellow variegation. $20 \times 5 \frac{1}{2}$ inches.

* 5I. Variegatum, Lowe (Vrighte, Clapham; Lux Lunx, Hollaston). Found in Yorkshire by Miss IV right, and distributed by the late Mr. Clapham. Normal, cxcept in being green and white. When not grown in a moist situation, the fronds soon fade in full sunlight. Length, 2 feet.

52. Willsii, Lowe (grandiceps, Wills). Found in 1870 , in Dorset, by the late $\mathrm{Mr}$. John Wills. The largest of all the grandicips forms; regularly crested, and having a large branching capitate liead ( 8 inclies wide). $36 \times 9$ inches.

\section{THE CHAFFY MALE FERN.}

\section{NePHRODIUM PALEACEUM.-Don. \\ (NEPHRODIUM FILIX-MAS of most authors.)}

A HANDSOME, thick fronded species, with shining fronds from 2 to 3 fect in length, the rachis being thickly clothed with bright brown scales. Fronds sub-cvergreen, or evergreen in shady situations. Broadly lanceolate, gradually tapering to the apex. Fructi. fication most abundant at the upper portion of the frond, but none near the base. A common English fern, though less so than Nephrodium Filix-mas. This is the species known as Lastrea pseudo-mas of Wollaston ; but Nephrodium paleaceum of Don (the normal type) has a prior claim for adoption.

Like $N$. Filix-mas, there are no difficultics in its cultivation.

\section{VARIETIES.}

I. abasipinnulum, Wollerston. Found in Westmorcland by Mrs. Robinson, of liowness. Lax. P'innules small, and absent at the base of the pinna. $27 \times 5$ inches.

2. Bakeri, Loze (polydactyla Bakeri, Bames). Found recently at Millom (English Lakes) by the Rev. IV. J. Baker. One of the best of the flat-crested varieties.

3. Beevere, Loruc. Found near Coniston by Miss Becrer. It differs from Pinderi in the pinne overlapping, so as to cause the frond to be imbricate.

* 4. Belperi, Lowe. Raised by myself in ISGS. Not unlike "cristatum," with heavicr crests.

5. crispare, Lowe (crispa, Larnes). Found in $1 \$ 6_{5}$, in Mardale, by Mr. J. M. Barnes. A robust fern, with deeply-cut undulate pinnules. It is larger growing than the erisfor of llowe.

6. crispatum, Hollerstom. Found in I)evon by $M \mathrm{l}$. (7. 13. Wollaston, and near Levens by Mr. I. M. Barnes. In lreland, by Mr. W. II. I'hillips and Rev. S. A. Lireman. Differs in being crispywared thoughout the fiond.

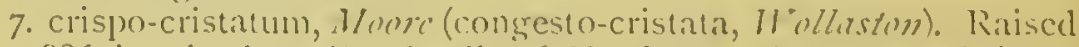
in IS86 by the late 1)r. Lyell, of Newbury. A congested form. 
Pinnæe crested, except near the tip of the frond, the tip itself brancl-ing and crested. I I $\times 5$ inches. Fronds stitt.

8. crispo-gracile, Lycll. Raised by Dr. Lyell, of Newbury. A distinct dwarf variety. Pinnze twisted and crispy. Length, 5 inches.

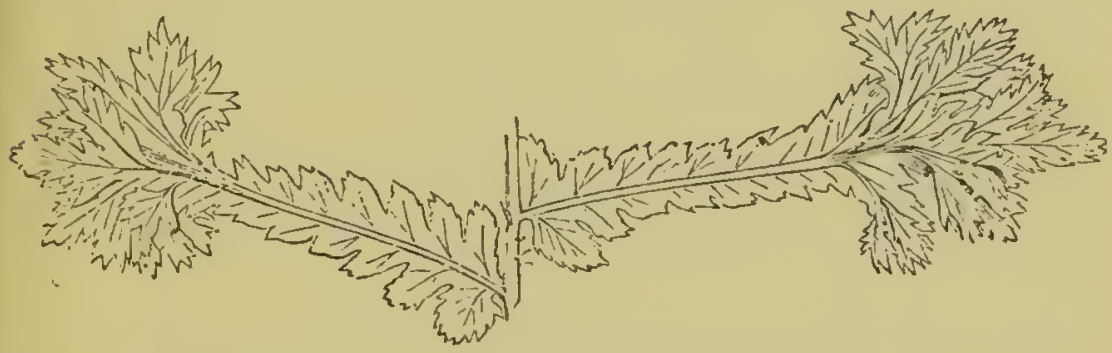

FIG. 40. -Nephrodiurn paleaceum, var. crispulum (upper pinnæ, showing bunch-cresting).

*9. crispulum, Lowe (cristatum-globosum, Druery). Found in I 879 in a wood about two miles fiom Bettws-y-coed by Mrs. Boyd, and has been growing in her garden until it came into my possession. It is an interesting variety, for it is almost a copy of $N$. cristatum, except that the cresting is in bunches instead of being flat. $36 \times 8$. A very similar variety was raised in 1865 , at Higlifield House, from cristatum.

- Io. crispum, Moore. Found in Wales, and given to The Hon. Mrs. Wrightson, of Warmsworth Hall, Doncaster. A dwarf, very stiff, erect-growing fern ; crisp. I I $\times 5$ inches.

II. cristato-angustatum, NIoore. A sport of cristatum, with much shorter pinne. Very narrow strap-shaped fronds, well crested. $24 \times 3$ inches. An intermediate variety between this and cristatum "Vinstanleyi" was raised at Highfield House in 1862.

I2. cristatum, Moore. One of our most beautiful symmetrical varieties, having the tips of the pinnee and the apex of the frond tasselled with a flat crest. It was found at Charleston, near St. Austell; also at Upper Cultra Wood, in Co. Down, by Mr. R. Milligan. The basal half of the frond is very heavily crested. $36 \times 8$ inches.

13. Fittii, Lozve (ramo-cristata, Jones). Raised by Mr. Fitt. This distinct variety is very ranose, branching several times from the base upwards. It is a branching form of $\mathrm{N}$. cristatum. A massive, attractive variety.

I4. furcillatum, Wollaston (sub-cristata, Moorc). Found in I86I, in North Devon, by Mr. John Dadds, of Ilfracombe. Fronds very wide. Pinnx narrow, and tassels less than in the var. polydactylum. $36 \times 9$ inches.

I 5. grandiceps, Joncs. History obscure.

16. Lyellii, Lowe. Raised at Highfield House from crispo-lineare (one of Dr. Lyell's sports), and is more marked than that variety. A narrow, well-crested form, with an erect habit, and fronds so remarkably stiff as to break if bent. Length, 6 inches. 
*17. magnificum, Lorue. Found by myself at Dunkeld in I \$67. $A$ bold, foliose form. $36 \times 8$ inches.

*IS. Mapplebeckii, Hoore (polydactyla, Wollaston). Found in I 862, in WTestmoreland, by MIr. J. E. Mapplebeck. Pinnæe contracted at the base. The branching apex much larger than in var. polydactylum. $31 \times 9$ inches.

19. monstrosum, Phillips. Found at Holywood by Mr. IV. H. Phillips. A monstrosity. $S \times 4$ inches.

*20. nitidum, Lowe. Found in IS67 by myself, at Dunkeld. Foliose, deep green, shining. $30 \times 7$ inches.

*21. pendens, Lorve (grandiceps Ranyard, Wollaston). Another very handsome, bold, symmetrical ferm, having very long, narrow pinne, drooping in a very graceful manner. Pinna crested, and the apex of the frond branched and crested. Length, 3 fcet. The name has been changed to pendens, as there is already a grandiceps.

22. Pinderi, Moore. Fonnd in I855, near Elterwater, by the Rev. G. Pinder. A distinct, handsome, narrow-fronded variety; tapering both to the base and apex, and terminating in a long, slender point. $36 \times 6$ inches. The late Mr. C. Monkman found a somewhat similar variety in I 862 at Coneysthorpe, near Malton.

23. pluma, Lowe. Found at Ncwcastle, Co. Down, by Mr. IV. H. Phillips. Pinnæ close, pinnules imbricate. A nice, plumy form. $17 \times 6 \frac{1}{2}$ inclies.

*24. plumosissimum, Love (fimbriata-cristata, Stunsfield). Another grand symmetrical form, found by Mr. Cropper. It is in the style of cristatum, but cut up into narrow lobes with fimbriate cdges. A very plumose varicty. Length, 2 feet.

25. polydactylum, Wollaston. Raised in 1872 by Mir. John Dadds, of llfracombe; found also in Co. Down, by Mr. IV. H. Phillips. Conspicuously crested. Pinnx an inch wide at the basc. $36 \times 8$ inches. There are several sub-forms of this varicty.

26. polymorphum, Barnes. Found in I 865, at Kentmcre, by Mr. J. M. Barnes. A fine variety, with variable, tripinnate fronds.

27. pumilum, Moore. Found on Snowdon by the late Mr. D. Cameron. A much smaller fern than N. propinquum, var abbreviatum. Compact, bushy habit. Sori, a single pair on cach pinnule. Length, 9 to 12 inches.

28. ramo-cristatum, Jones. Found in 1 S7 1 , in Lancashire, by Mr. IVilson, of Bowness. This very fine variety is in the possession of Mrs. Hodgson, of Ulverston. Branching several times, and terminating in a wide, capitate head. J'inne crested in compact bundles. Length, 2 feet.

29. ramo-digitatum, Lozwe (ramo-furcillato-cristata, II cllastom). Found in 1S71, in Langdale, by Mr. J. A. Wilson. A handsome varicty. Very ramose, and having forked crests.

30. ramo-furcillatum, Wollasfom. Found in IS6 4, in North Devon, by Mr. I)adds, of Ilfracombe. Jianching and furcate. Length, 2 fect 2 inches.

*31. ramosissimum, Nanre. Found in 1864 , in North Walcs, by the late $M \mathrm{r}$. Robert Wright. A rery clistinct, sterile variety. 
Fronds dividing into two or three at the base of the stem, and each again dividing 2 or 3 inches higher, and becoming very ramose 3 or 4 inches below the apex, making the frond as broad as it is long. The tips of the pinnæe crested. Length, I foot 6 inches.

32. ramulosissinum, Wollaston. Raised from spores in 1865 by Mr. Sim, of Foots Cray. A very curious dwarf variety. More than half the length of the frond consists of its naked stem, above which it is a diminutive grandiceps. Length, $3 \frac{1}{2}$ inches.

33. recurvum, Moore. Found in 1857 , near Doncaster, by $\mathrm{Mr}$. S. Appleby. Recurved. Length, is inches.

*34. revolvens, W'ollaston. Found at Troutbeck Bridge, IVestmoreland, by $\mathrm{Mr}$ : F. Clowes. A remarkable, thin-textured variety. Owing to the pinnæ curling round the back of the frond, the width is only 2 inches. Length, $i$ foot.

35. rotundatum, Philitps. Found at Ligoniel by Mr. WV. H. Pliillips. Pinnules rounded and denticulate. Very distinct. I $8 \times 4$ inches.

36. Sangii, Lozve (crispa-cristata-angustata, Sang). A distinct, dwarf, very narrow, crisp, and well-crested variety, with thick stem. Length, 6 inches.

37. Schofieldii, Moore (ramulosa, Wollaston). Found in I855, at Derby, by Mr. J. Schofield, of Rochdale. The stem divides in to two foliose fronds, and these again divide at the tips. Length, 2 to 3 inches. Var. ramulosissimum was raised from this variety.

38. Stableri, Moore. Raised by Mr. Stabler, of Levens. Not unlike Pinderi, but in every way larger.

39. Willsii, Lozve. Found in South Devon by the late Mr. IVills. A grand polydactylous fern.

40. Wilsoni, Lozve (cristata Wilsoni, Wollaston). Found in I $87 \mathrm{I}$, in Langdale, by Mr. J. A. Wilson. Distinct from all other crested forms, having golden-coloured, pendulous pinnules.

\section{ALLIED MALE FERN. \\ NEPHRODIUM PROPINQUUM.-Lorve. (LASTREA PROPINQUA.-Wollaston.)}

A PERFFCTLY deciduous species, with fronds and pinnæ concave ; pinnules biserrate. Indusium embracing spore-cases, persistent, and entire. Fronds dull pale-green, and of a soft texture. This fern approaches nearer to $N$. paleaceum than to $N$. Filix-mas, and may eventually prove to be a mountain form of the former.

\section{VARIETIES.}

I. abbreviatum, Babington. Considered the normal form of the species. It has been found on Snowdon by the Rev. J. M. Chanter, in Teesdale by Mr. Backhouse, on Cronkley Fell by 1 y. self, Ingleborough by the Rev. G. Pinder, Coniston by Miss Beever, in W'estmoreland by Mr. G. B. Wollaston, Glen Isla by Mr. J. Backhouse, on Ben Lawers by Mr. P. Neill Fraser and myself, at 
Killarney by Mr. R. Barrington, and on the Clova Mountains by Mr. T. Westcombe. Dwalf, though larger than N. paleaccum var. pumilum. Pinnate, the lowest pinnules alone being separate, the remainder decurrent. Pinnules large. Length, I foot.

2. attenuato-cristatum, Barnes. Found at Clougha by Mr. J. Stewardson. A narrow, attenuate, crested variety.

3. Barnesii, Loave (cristata Barnes, IVollaston). Found in Langdale, Westmoreland, by Mr. J. M. Barnes. The finest of all the crested forms. Pinna well cristate, and the apex heavily crested. $27 \times 5 \frac{1}{2}$ inclies.

4. confluens, Ifoore. Found in Swindale by Mr. J. M. Barnes. A ncat variety, with confluent pinnules.

5. congestum, Barnes. Found in Patterdale by Mr. WV. Foster. A dwarf, congrested form.

6. Cowardii, Lowe (cristata Cowardii, Bames). Found near Ambleside by Mr. J. Coward. A pretty, small-growing, neatlycrested variety.

7. crispum, IVollaston. Found in Wales. Pinnx overlap each other, and are deeply pinnatifid. Scgments also overlapping, crispy, and crowded.

8. cristatum, Moore. A plant was found in Borrowdale many years ago by Mr.J. D. Harrison; a second in 1863 , in Sinindale, by Mr. J. M. Barnes, who considered it distinct; and a third in I 87r, at Ambleside, by Mr. Coward. Graceful, and very neatly crested.

9. curvato-cristatum, Barnes (the Swindale variety found by Mr. Barnes). A dwarf, interesting, small-crested form, having curvingdown pinnules.

Io. dactyliferum, Moore. Found also in Swindale by Mr. J. M. Barnes. A fine polydactylous form, with long, finger-crested pinnules.

I I. erosum, Moore. Found at Keswick by Miss Wright, and at Troutbeck by $\mathrm{Mr}$. Clowes. This has the pinnules recularly reduced.

12. excurrens, Woore. Found on Langdale by Mr: J. M. Barnes. An interesting, excurrent fern, with rery dark-green fronds.

13. flabellato-cristatum, Burnes. Found in swindale by Mr. J. M. Barncs. Crest fan-shaped. Rather inconstant.

14. furcans, Barnes. Found in Marwood by Mr. IV. Foster. Fronds forked.

I 5. Gottii, Lowe (cristata Gott, Whitrell). Found at Low (Gill by Mr: J. Gott. Another form of cristitum.

16. gracile, Moore (eracile-furcins, foms). Found in $1 S S 6$ or I 887 by $\mathrm{Mr}$. Foster. Very graceful, the fronds being pendent and unusually wide. $A$ more beatiful form hald been previously foumd at Mardale by Mr. J. M. Bames, having narow, fincly-cut pinnules.

17. grandiceps, Mone?. Found at Mardiale by Mr.J. M. Bames. This has a very large, spreadinir head.

18. interruptum, Houre. Found at IVindermere by Mr. F. Clowes. Both fronds and pinnules irregular. 
19. laciniatum, Lozve (laciniato-truncatum, Barnes). Found in Patterdale by Mr. WV. Foster. A laciniate, truncate form.

20. lineatum, Lowe (lineatum-furcans, Barmes). Found in Patteldale by Mr. IV. Foster.

2I. morsum, Loze (erosa-Barnesii, Moore). Found in Swindale by Mr. J. M. Barnes. A delicate variety, with evenly reduced pinnules.

22. multifidum, Barnes. Found in Mardale by Mr. T. Airey. A small-growing, multifid form.

23. multiforme, Moore. Found in Long Sleddale by Mr. J. M. Barnes. Fronds variable and very irregular.

24. nanum-cristatum, Jones (cristato-nanum, Sim). A dwarf, narrow-crested forn.

25. productum, Foster. Found in I $\$ 87$ or 1888 by Mr. Fostel. When fully developed, this is a very fine, slender fern. 'The lower pinnules are long and much divided.

26. pulchellum, Stansfield. Found in Patterdale by Mr. IV. Foster.

27. Smithiesii, Barnes (crispata-incisa, Jones). A distinct, interesting fern. Found by Mr. Smithies. Pinnules finely cut and crisped.

28. strictum, Moore. Found in Mardale by Mr. J. M. Barnes. Distinct. Pinnules much reduced.

\section{THE CRESTED BUCKLER FERN.}

NEPHRODIUN CRISTATUM.-Michaux.

(LASTREA CRISTATA.-Presl.)

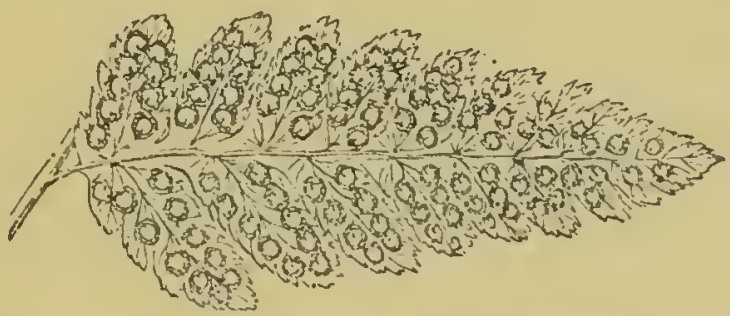

F1G. 4I.-Nephrodium cristatum, pinna (showing fructification!

A RARE and local fern, growing only in boggy localities. It has been found near Ipswich, Lynn, Dersingham, Holt, Yarmouth, Norwich, Wymondham, Newcastle-under-Lyne, Oxton Bogs, Bulwell Marshes (not now), Wybunbury Bog, Knaresborough, and Malton. It is also a native of France, Germany, Italy, Switzerland, Russia, Belgium, Holland, Scandinavia, Siberia, Canada, and the United States.

Fronds from I to 3 feet, of which one-third is the stipes. Erect in growth. Narrow, linear-oblong, sub-bipinnate, lapering to the apex. Lower pinne distant. Sori large and conspicuous. Deci- 
I44 BRITISH FERNS.-SUB-ORDER II. TRIBE IO.

duous. The normal form is distinet in appearance from all other species.

VARIETIES.

I. Clintonianum, Birkenhead. A North American variety. Length, 3 feet.

* 2. confluens, Lowve (cristatum-confluens, Clapham). Found by myself, on Oxton Boys. Normal in size ; pinne confluent.

3. Floridanum, Birkenhead. A large-grower, from Florida.

4. spinulosum, Moore. Basal pinne more remote and larger, and more nearly like some of the forms of "spinulosum." It is a much more common form, growing in damp boggy places, and sometimes in woods.

5. uliginosum, Moore. More lincar-lanceolate, with oblong acute pinnules. Only found growing in boggy situations, mostly amongst plants of the normal form.

\section{THE RIGID BUCKLER FERN. \\ NEPHRODIUM RIGIDUM.-Desvanx. (LASTREA RIGIDA.-Pres/.)}

ANOTHER mountain fern; with dull-green fronds of from I to 2 feet high; somewhat lanceolate, bipinnate, and scented. Not easily confounded with any other species. It has been found in Cornwall, also in Yorkshire (Wharnside, near Ingleburgh, and near Settle); in IVestmoreland (Arnside, Farleton, and on Hutton Roof Crags); and in North Lancashire. It is a native of France, Germany, Switzerland, Sardinia, Italy, Sicily, Dalmatia, Hungary; Russia, Siberia, and Asia Minor.

A deciduous species, confined to limestone mountains at heights ranging from 1200 to $\mathrm{I} 500$ feet.

\section{VARIETIES.}

I. abruptum, Lowe. Found at Whitbarrow, by Mr. J. M. Barnes. An abrupt-ended variety.

2. argutum, Birkenhead. A North American varicty. Fronds smoother and more triangular.

3. cristatum, Barraud. Found recently. Small crests throughout the frond. Mr. I) ruery possesses this plant.

4. interruptum, Barnes. Found at Arnside, by Mr. J. Crossfield. An interrupted form.

5. polyclados, Moore. Found at Farleton Kinott, by Mr. J. M. Barnes, and at Crosby Ravensworth, by Mr. Clarke. Fronds divide into two, either at the base or higher up.

6. ramosum, lowe. Received from Mr. Clarke's gardener, at Floss House, Crosby Ravensworth, Westmoleland. It difiers in two fronds rising from one stem. Another variety, polycledes, found at Arnside, only differs in having the frond sometimes dividing in the upper parts as well as at the base. This form was sent to me in 1863, and it is still in my fernery, and has retained its branching habit. Nore dwarf than the normal form. 
THE BROAD BUCKLER FERN.

\section{NePHROdIUM SPINULOSUM.-Desian.t.}

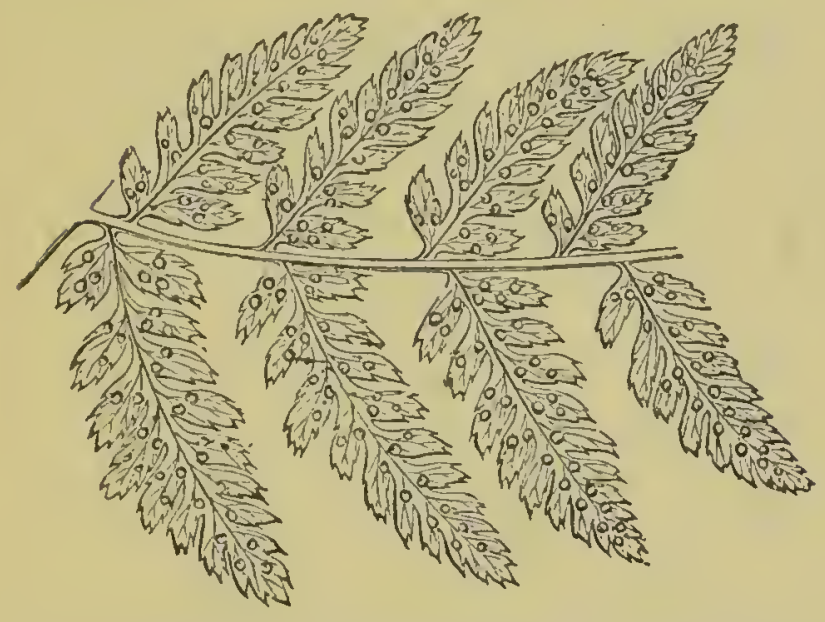

Fig. 42-Nephrodium spinulosum, pinna (showing fructification).

A WORD or two is requisite in order to point out why the ferns known as Lastrea dilatata and L. amula are included in the present fern.

There can be no doubt that locality, especially height above the sea, changes the character of a plant. We may instance "the common Brake," which attains 12 feet in height on Longridge Fell, and yet only 4 inches near the summit of Hellvelyn. As a rule, ferns are diminutive on mountains. In a rood at Hackness, near Scarborough (I am speaking of twenty years ago), N. dilatatum (Section $\gamma$ ) was near the base of the hill 5 feet high, and was common to half-way up this hill, where N. amulum (Section $a$ ) mingled with it; higher, xmulum was common and dilatatum absent. My brother and myself being surprised at this change, we determined to test it; and from many thousand plants of xmulum we removed 500 to Highfield House. In a couple of years, several changed to dilatatum; the next year an increased number, until at length xmulum was the exception to the rule. At the same time we had a score in pots, but none of these changed. The same has occurred with the mountain form alpinum, dwarf plants on removal having much increased in size. The Oak fern, only an inch high, and the Beech fern, not much larger, when gathered at the summit of Ben Lawers, assumed their natural size in three or four years. Polypodium vulgare, var. cambricum, and Scolopendrium vulgare, var. crispum, when planted in a wood, gradually reverted to the normal form of the species, whilst divisions of the same plants grown in pans did not change; and, again, divisions taken from those planted out and repotted did in the course of time resume their original character of cambricum 
and crispum. Further, when I came to reside at Shirenewton Hall, I brought a superb collection of Scolopendriums to this place, which were unfortunately planted in an unsuitable situation; and the result was that every one of them (even the most ramose or most rugose forms) became as normal as the common Hartstongue. Several years later some'were removed into a better situation, and in three ycars they had returned to their original varietal forms. Two years ago the remainder were treated in a similar manner, and are now assuming their original characters. 'This is strong presumptive evidence, that the following may really belong to one species.

Nephrodium spinulosum has bcen divided into three sections, viz. :-

$$
\begin{array}{cc}
\text { Section } & a . \text { xmulum. } \\
, & \beta . \text { alpinum. } \\
" & \gamma \text {. dilatatum. }
\end{array}
$$

\section{Section a. AMULUM. (Hay-scented Fern.)}

The distinctive characters are dwarfiness, crispy fronds, and scent like new-mown hay, the last character being said to be unlike any other species; but here, where the Brake is commonly cut as a substitute for straw, the scent, when freshly cut, is even more powerful than that of cemulum.

\section{VARIETIES.}

I. xmulum, Swar/z (Lastræa xmula, Brackenridge; L. fœnisecii, If'atson; L. recurvum, Neametn). A beautiful crispy fern, so strong as to be difficult to break, either in the lcafy or stem portion. Found in Cornwall, Devon, Somerset, Gloucester (Boyle), Hereford, Shropshirc, York, Lancaster, Cumberland, Northumberland, Glamorgan, Pembroke, Anglesea, Merioneth, Carnarvon, Forfar, Dumbarton, Argyle, Inverness, Arran, Mull, North Uist, Orkney, Guernsey, Antrim, Londonderry, Donegal, Mayo, Galway; Wicklow, Waterford, Clare, Cork, Derry, Louth, Armagh, Tyrone, Fermanagh, Cavan, Sligo, and Leitrim.

2. angustipinnulum, Moore. Found at Antrim by Mr. D. Moore, and in Co. Down by Mr. WV. H. Phillips. In this the secondary pinnules are more confluent : and the lobes are irregularly shortenecl.

3. capitatum, Iotee. Found in Hackness Wood by my son, the late Colonel A. E. Lawson Lowe. Crested and conspicuously capitate.

*4. cristatum, Jones. Found in North Devon by Mr. Gill. Well crested; rather dwarf.

5. interuptum, Clapham. Found at Hackness both by the late Mr. Clapham and myself, and subsequently in the same locality by my son. Fronds depatuperate; pimnie and pinmules shortened and misshapen.

6. ramosum, Claphem. Found by the late Mr. Clapham. Twin fronds from the base. 


\section{Section $\beta$. ALPINUM.}

(Distinguished by its dwarf and more slender fronds.)

I. alpinum, Hoore. Found by Mr. Clowes, at Haweswater, and on Ben Lawers, by Mr. P. N. Fraser and inyself. A small, delicate form.

2. Aireyi, Lowe (interrupta Aireyi, Barnes). Found in 1876 , in Patterdale, by Mr. T. Airey. Evenly interrupted.

3. angustipinnulum, Moore. Found in Lancashire, by Mr. R. Morris; and in Yorkshire, by Mr. W. Willison. A clepauperate yet symmetrical form, with very narrow pinnules.

4. anomalum, Lowe. Found in Yorkshire, by the late Mr. Clapham. A dwarf depauperate variety.

5. Barnesii, Lowe (interrupto-Barnesii, Lowe). Found in I865, at Witherslack, by Mr. J. M. Barnes. Defective ; pinnules reduced.

*6. calomelanos, Lowe. Found in I 867, by myself, on Ben Lawers. More finely divided than lepidotum. Length, ro inches.

7. contractum, Lowe (alpinum-contractum, Moore). Found in I 864, at Mardale, by Mr. J. M. Barnes. Depauperate, with reduced pinnxe and pinnules.

8. Crouchii, Loive (interrupta Crouchii, Barnes). Found in 1864, at Loughrigg, by Mr. WV. Crouch. Defective, with reduced pinnules.

9. dumetorum, Moore. Found in a number of places. Dwarf broad fronds, with a glandular surface. Length, 2 inches.

*Io. ebeneum, Lozwe. Raised by myself, in I862. Dwarf. Stem ebeneous.

* I . Fraseri, Lowe. Found in I867, on Ben Lawers, by myself. Dwarf and crisp.

I2. grandidens, Lowe (interrupto-grandidens, Clapham). Found in 1873 , in Yorkshire, by the late Mr. Clapham. Divarf; interrupted; half of the pinnules minute.

13. Howardii, Monkman (cruciata pinnula, Fox). Found in I 863 , in Ray Wood, Castle Howard, by Mr. J. Greenwood, and soon after by Mr. Monkman and Mr. Stabler (six plants were found in this wood. A remarkable fern with cruciate pinnules.

I 4. hymenophylloides, Loive. Found at Ilfracombe by Mr. Dadds. A very Filmy-fern-looking variety. $9 \times 2 \frac{1}{2}$ inches. Stiff and erect in growth.

I 5. irregulare, Moore. Found in 1862 at Witherslack, by Mr.J.M. Barnes; an irregular form.

16. lepidotum, Moore. History obscure. A much-divided, distinct, elegant form.

* I 7. ornamentum, Lowe. Found in I867, on Ben Lawers, by myself. A slender dwarf variety with twisted pinnules.

I 8. plumosum, Jones. Found on Ben Nevis. A rery beautiful plumose form.

I9. pumilum, Moore. Dwarf, not uncommon.

20. ramoso-cristatum, Barnes. Raised in 1874 by Mr. J. M. Barnes. Branching at the base and again in the middle (below the pinna), 


\section{48 BRITISH FERNS. - SUB-ORDER II. TRIBES IO AND II.}

ending in large capitate, closely-crested heads. Length, ij inches.

21. ramosum, Moore. History obscure. Dwarf, twin-fronded, and again dividing.

*22. spectabilc, Lowe. Found in 1867 , on Ben Lawers, by myself. A lepidotum-looking variety with much attenuated fronds. Lcngth, 12 inches.

*23. spectabilc-ramosum, Lowe, $\dagger$ found in 1867 , on Ben Lawers, by myself. Like spectabile, with the apex forked.

\section{Section $\gamma$. DILATATUMI.}

The large-growing form. Exceedingly common, and requiring but little care in its cultivation. Where there is an abundance of halflccayed leares, it grows to a great size. Fronds spreading and ovate lanccolate in form, bipinnate and even tripinnate. Basal pinnec obliquely triangular; pinnules very dentate. Usually erect, with a long densely scaly stem. Length, from i to 6 feet.

1. Bootii, Birkcnliead. A North American variety. Length, $2 \frac{1}{2}$ feet.

2. Chantere, Moore. Found in Devon by Mrs. and the Rev. J. M. Clanter. Pinnæe distant; pinnules blunt; frond oblong lanccolate; apex attenuated. Length, 2 feet.

3. Clovellyanum, Lorec (cristatum Drucly, Drucry). Found in I858, at Clovelly ; neatly crested.

4. crispato-cristatum, fones (cristata Oscroft, Mollirston). Found in I873, near Bristol, by Mr. J. Oscroft. Pinna minutcly crested ; rachis dividing and subdividing into a foliose, crisped, and crested head, 9 inches or more across. Length, 2 fect.

5. crispum, Wollaston. Said to be a good crisp form.

6. cristato-gracile, fones (cristata Roberts, Wollurston). Found in 1870 , in Camarvon, by Mr. Roberts. Pinna narrow; pinnules small; better crested than any other varicty. Length, ig inches.

7. cristatum, Moore. Found near Doncaster by Mr. S. Applcby, and a more marked form in Yorkshire, by Miss Wright. I'inna twicc forked.

8. Drueryi, Loare (stipitato-lacerata, Drucryy). Found in ISS4, at Campsil, by Mr. C. T. Druery. An interesting depauperate form. $6 \times 1 \frac{3}{4}$ inches.

9. folioso-cristatum. A vigorous, handsome, foliose form, found in the Azores. Fronds and pinne heavily crested.

ro. folioso-digitatum. Also found in the Azores. A fine variety. Fronds heavily polydactylously crested.

I . grandiceps, Burnes. Raised by Mr. J. M. Barnes. A grand varicty, very heavily crested.

12. hyloridum, Stansficld. Accidental seedling. Came up on the bole of another liybrid, i.c. remotum (a cross between Nephrodium spmulosum and N. Filix-mas).

Nos, I I, 17, 20 and 2 r were all found on Len Lawers, beneath one henp of stones. 
13. interruptum, Moore. Found near Harrogate by the late Mr. Clapham, and also in the Hole of Hercum, by the late Mr. Monkman. Pinnules irregular, some wanting.

14. polydactylum, Wollaston. Found by Mr. Turner. Manyfinger crested.

i5. remotum, Lorve (Lastrea remota, Moore). Found in 1859 , at Windermere, by Mr. F. Clowes (this and hybridum might equally be placed with N. Filix-mas, though the resemblance is nearer the present species; they are hybrids between the two). Fronds erect, oblong lanceolate, smooth; basal pinne unlike N. spinulosum. Copiously soriferous; but after a score trials I have failed to raise

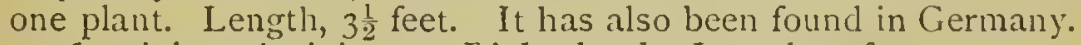

16. stipitato-laciniatum, Birkenhecrd. Length, 2 feet.

17. tanacetifolium, Moore. Is not uncommon. A large tripinnate variety with triangular fronds.

\section{Tribe 11. POLYPODIEAE.}

\section{THE BEECH FERN. \\ Polypodium Phegopteris.-Linnaus.}

A BEAUTIFUL fern, creeping along damp ground, either in woods or on shady banks, and is more abundant in mountainous districts The entire length of the frond varies from I incla (under rocks near the summit of Ben Lawers, E. J. L.) to 20 inches in woods at Hackness, near Scarborough (and near Ambleside), one-half of which is stalk. Some few years ago there were carpets of this ferm in woods near Scarborough, more than a dozen yards across, with not a single vacant spot. It inhabits fourteen counties in England, seven in Wales, seven in Ireland; the Isle of Man ; and Shetland; and it is generally distributed through Scotland. Found throughout Europe, and extends from Italy to Iceland. Widely spread in North America, also Kamtschatka and the Altai Mountains. The frond is ovate-triangular; the basal pair of pinne curved downwards, and the pinnee narrow from the base upwards. Colour, pale dull-green.

\section{VARIETIES.}

1. caudatum, Lowe. Found on Ben Lawers by myself. A very divarf form with a caudate apex; somewhat depauperate.

2. Fosteri, Loave. A beautiful laciniate form. Found by Mr. Foster in the Lake district.

3. interruptum, Bames. Length, 4 inches. Found at Witherslack by Mr. J. M. Barnes, of Milnthorpe, in I863. This is a very narrow, irregular form; the pinne being variable in size, their apices truncate, and the tip of the fiond tail-like.

4. laceratum, Druery. Found in 1889 , near Settle, by Mr. Barraud. Fronds approaching P. vulgare, var. cambricum, in cutting.

5. multifdum, Hoore. Differing in having a portion of the lobes multifid and longer; and in the tips of the ninna being crested. I 
found it in great abundance in 1857 , near Stockghyll Force, Ambleside, where it clothed a bank of a wet shady lanc for six or eight yards. In 1865 a similar form was found by the late Mr.J.J. Jones and by Mr. J. E. Mapplebeck in the same district.

6. strictum, Barnes. Found at Witherslack by Mr. J. M. Barnes.

\section{THE OAK FERN.}

\section{Polypodum Drvopteris. - Linnaus.}

A s.mali, exquisitcly beautiful species, inhabiting mountainous, rocky situations in shady woods; or beneath hedges where the atmosphere is damp but not the soil. It is sometimes cilled "The Smooth 'Three-branched Polypody," bccause the frond is threebranched. Usually varying in sice from 4 to 12 inches, but occasionally very diminutive. I found it under cavernous stoncs near the summit of lien Lawcrs, not much morc than one inch long. Frond triangular, and of a brilliant refreshing green. Rhizoma crecping. This fern can only be confused with the Limestone Polypody; but the latter has its fronds as if dusted with lime. It is a common Scotcli and Welsh fern, and occurs in fiftcen English counties. In Ireland it is cxceedingly rare. Widely spread in Europe and America. A rapid-growing fern with a creeping rhizome. It is met with in very large clumps. Easily cultivated.

Therc are no varieties.

\section{THE LIMESTONE POLYPODY.}

\section{POLYPODIUM ROJERTIANUM.-Hofmam.}

\section{(P. CAlCareun, Smith; and I. Drvopteris t'(2)., Bolton.)}

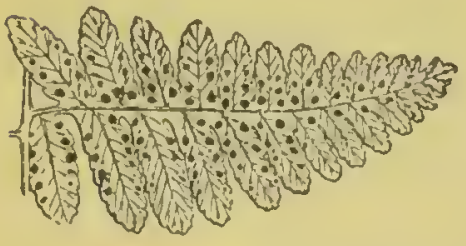

I'IG. 43.-Polypodium Rubcrtianum (puna, slowirg fructification).

IN appearance very like the Oak Fern, but more obliquely triangular. It varies from $S$ to is inches in length. The stipes is much longer than the rachis, whilst in Dryopteris it is just the reverse. This spccics delights in sunshine; Dryopteris, in shatde. 'Ihe fronds bcing pubescent, they have the appearance of being dusted over with lime. Rhizoma, crceping. Found in Cumberland, Westmoreland, Yorkshirc, Derbyshirc, Gloucestershire, Wiltshire, Somerset, Caemarvon, Denbigh, and Glamorganshire. Near liuxton its rhizomes creep about heaps of stones; and plants can be obtained by remoring the stones, when it is seen that the plints are luxuriating without the roots penetrating soil. $1 \mathrm{t}$ is found in Fance, Ciemany, Switzerland, Hungary, Norwily, Canadil, the United States, and on the Ilimalnyan Mlountains.

There are no varictics. 


\section{THE ALPINE POLYPODY. \\ POLYPODiun alpestre.-Hoppe.}

A LADÝ-FERN looking plant, but having circular (minute) sori, which are not covered with an indusium. It is only found on mountains of from 2,000 to 4,000 feet elevation. The fronds are somewhat lanceolate and bipinnate. Usually 20 inches in length, but sometimes double this size. The

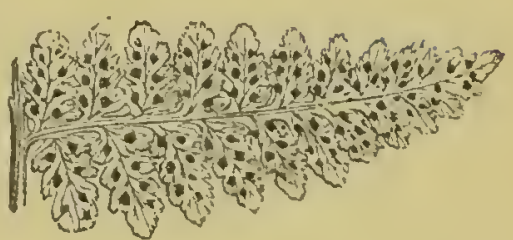

FIr. +4.--Polypodium alpestre (l i na, showing fructification).

habit is erect, and the fronds are deciduous.

First recognised as British by Mr. Watson, in I $\delta_{4} \mathrm{r}$. It has been found on the Clova mountains by Mr. Backbouse and Mr. G. Lawson; on the Deeside mountains, by Mr. T. Westcombe and Mr. Backhouse; on Ben Aulder, by Mr. WVatson; Lochnagar, by Mr. Croall ; and on Ben Lawers, by Mr. Fraser and myself. It appears to be abundant though local. It is exclusively a Scotch fern, as far as the United Kingdom is concerned : but it is found in Switzerland, Germany, Russia, Norway, Sweden, Lapland, and the Caucasus.

\section{VARIETIES.}

1. flexile, Neruman. Found in Glen Prosen (Clova). Handsome and distinct. Length, 6 to 18 inches. Very narrow; the pinn:e shorter, and the pinnules less in number. Sori only near the base of the frond.

2. laciniatum, Stansfeld. Raised from spores by Mr. Stansfield. More dense than flexile, and the pinna laciniate.

3. lanceum, Moore. Found on Clova by Mr. G. Lawson; and on Lochnagar by Mr. Croall.

4. tripinnatum, Moore. Found at the Wells of Dee by Mr. G. Lawson. Fronds large, tripinnate, and the pinnules very large.

\section{THE COMMON POLYPODY.}

POLYPODIUA vUlGare.-Linnaus.

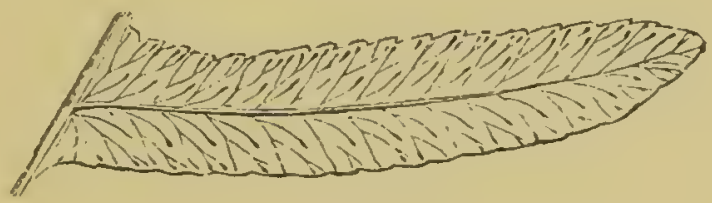

FIG. 45.-.ove of Polypodium vulgare.

THE common Polypody cannot be confused with any other British fern. The stout, firm fronds attached to the thick, creeping rhizoma in such a manner that they separate from it, like leaves 
from a branch as they approach decay, is a unique character. The fronds iary from 2 to 22 inches in length; are linear, oblong in form ; deeply pinnatifid; with large, conspicuous sori. Except in very hard winters, the fronds remain green till spring, when they are cast, and fresh ones appear. It grows on rocks, walls, trecstumps, and banks, and is common throughout Great Britain and Ireland, from the level of the sea to a height of more than 3,000 feet. It is also abundant throughout Europe, Siberia, Kamtschatka, Canada, the United States, California, Mexico, and Guatemala.

The sections including Cambricum and semilacerum are not un. common in Monmouth and Wales.

Readily cultivated if grown in leaf mould, sand, fibrous loam, and lumps of decaying wood, care being taken that the rhizomes shall be fastened on the surface of the soil. In the varieties of this fern the departure from the normal form is unusually great.

\section{VARIETIES.}

These have been grouped in sereral sections, Section $\delta$ contain. ing all those that could not be classed in Sections $\alpha$ to $\gamma$.

Section $a$. plumosum.
$\quad, \quad \beta$. cristatum.
$" \quad \gamma$. semilacerum.
$", \quad \delta$. anomalum.

Section a. contains feathery varieties, such as Cambricum, Cornubiense, and pulcherrimum.

Section $\beta$, the tasselled, branched, or capitate forms.

Section $\gamma$, semilacerum and omnilacerum, i.e., lacerate forms.

Section $\delta$, anomalum (a term used to denote that these are not classed). This section contains those varieties not included in the first three classes.

\section{Section a. PLUMOSUM.}

I. Barrowi, Lozve (Cambricum Barrowi, Barnes). Found in 1874 , at Witherslack, in the Lake district, by Mr. T. Barrow. It is a splendid form ; with very dense, finely-cut, thin-textured fronds.

2. Cambricum, Linnceus (plumosum, Irollaston). A well-known, plumose, sterile variety. Found many years ago in Wales. Mentioned as early as 1743. The late Mr. Joseph Sidebotham, of Manchester, found it in North Wales, at Mill Dingle, Beammaris, and Conway Castle; also at Troutbeck, near Ambleside; and at Flenarim, in County Antrim (the Irish form not sterile). Found in South Deron, in 1867, lyy $\mathbf{W}$. Easterbrook. It is also recorded from Monmouthshire, Glimorganshire, Cheshire (where it was found in a wood near Macclesficld), and from Amondsbury, ncir Bristol.

3. Claphami, Lorec (multifido-clegantissimum, Clupham?). cross between a crested form and "Cornubiense," raised by the late $\mathrm{Mr}$. Clapham; in fact, a crested Cornubiense, 
4. Cornubiense, Moore (elegantissimum, Stansfeld). The original plant was found in 1867 in Cornwall, growing on an ash pollard, and was distributed by the Rev. J. B. Whyte. A wonderfully fine, divided form, somewhat resembling the Killamey Fern, yet also having some normal and some half-normal fronds. $14 \times 4 \frac{1}{2}$ inches.

5. foliosissimum, Lowe (Cornubiense-foliosum, Clapham). Another of Mr. Clapham's fine varieties. A very mossy form.

6. Fowleri, Lozve. Raised from Cornubiense by the late Mr. Fowler. Has no normal fronds.

7. Hadwini, Lowe (Cambricum Hadwini, Barnes). Found in 1875, in Silverdale, by Mr. Hadwin. A beautiful plumose variety.

8. Hutchisoni, Baker. Found in Carmarthenshire in 1889 by Mr. Hutchison, and now in the Oxford Botanic Gardens, having been secured by Mr. Baker (curator). A form of trichomanoides. Apex lax, and finely drawn out in a stag's-horn manner. $8 \times 3$ inches.

9. Lyellii, Lyell. A plumose form. Raised by Dr. Lyell. $15 \times 5$ inches.

Io. Oakeleya, Lowe. A divarf form of Cambricum. Found in 1868, at Raglan, by Mrs. Bagnall Oakeley. $9 \times 4 \frac{1}{2}$ inches.

II. pluma, Lowe. Found 30 years ago, on Tintern Abbey, by Mr. Cosvburn. A handsome variety, with characters between Cambricum and pulcherrimum. Sparingly fertile. $20 \times 5 \frac{1}{2}$ inches (stipes, 6 inches).

12. Prestoni, Lozve (Cambricum Prestoni, Burnes; congestum, Jones). Found in I $87 \mathrm{I}$, at Yelland, by Mr. R. Preston. A grand, congested, tripinnatifid plumosum. II $\times 4 \frac{1}{2}$ inches.

13. pulcherrimum, Stansfield. Found in I861, at Whitbarrow, by Mr. T. Addison. Texture thicker than Cambricum; lobes rounded. A handsome, robust, tripinnatifid form. I $9 \times 8 \frac{1}{2}$ inches.

14. pulchritudine, Lowe (pulcherrimum Lowei, Jones). Raised by myself in 1884. A handsome, finely-cut variety. Fronds concave. $12 \times 4 \frac{1}{2}$ inches.

15. serra, Wollaston. Found in 1868 , in Furness Fell, by Mr. J. A. Wilson. A sub-Cambricum, with erect basal pinnae.

16. trichomanoides, Backhouse. A sport in the York Nursery of Cornubiense. Finely divided; and with no normal fronds. $12 \times 4 \frac{1}{2}$ inches.

17. triumphale, Lowe. Raised in I 884 by myself. Characters, midway between Cambricum and pulcherrimum. Growth, horizontal. $16 \times 5$ inches.

\section{Section $\beta . \quad$ CRISTATUM.}

I. acuto-bifidum, Wollaston. Found in I 858 , at Stainton, by Mr. J. M. Barnes. Acute bifid points.

2. bifido-cristatum, Mapplebeck. Found in 1867, near Grange, by Mr. T. Walmsley. A fine bifid, crested form, with a branching crested head. $5 \frac{1}{2}$ inches wide. $17 \times 2 \frac{1}{2}$ inches.

3. bifidum, Francis. Found in many localities. Points of segments bifid. 
4. contractum, Lowe (cristatum-contractum, Jones). Raised by my'self in I $\$ 75$. Costa splits and forms a compact, crested cornute head. I $4 \times 4 \frac{1}{2}$ inches.

5. cristatum, Moore. Found in $185+$ in County Cork, by MIr. H. S. Perry. A fine foliose, well-crested capitate form.

6. diadema, Lowe. Found by myself in 1886 , at Penhow, Monmouthshire. Segments bifid. Small crest. $9 \times 2 \frac{1}{2}$ inches.

7. Fosteri, Iowe (cristatum Clewarth, Hollaston). Found in I $\$ 76$ in County Clare. Greatly crested and capitate. Segments much narrower than those in cristatum. A splendid form. $16 \times 5$ inches.

S. glomeratum, Mcly. Found in $1 \$ 7 \hat{3}$, by Mr. Job Mullins, in Dorset. Half stem, the leafy part broader than long, tips crested. $\$ \times 6$ inclies.

9. grandiceps, Bames. Found in I868, near Grange, by Mrs. Fox. Heavily crested. A grand variety. $16 \times 4$ inches.

10. Hodgsona, Lorve. Found by Mrs. Hodgson. Crested and capitate, contracting to the crests. $12 \times 23$ inches.

II. lomarioides, Loave. Found in Ireland by Mr. Stewartson. Very narrow. $\delta \times 0_{4}^{3}$ inches.

12. Martindalei, Lowe (multifidum, Noor'). Found in I $\$ 65$, near Staveley, by Mr. J. A. Martindale. A nice crested form.

13. multifidum, Moore. Found at Whitbarrow by Mr. F. Clowes. Crested.

I4. Parkeri, Lozve (multifido-cristatum, Moore: grandiceps Parker, IVollaston). Found in 1854 , in Somerset, by Mr. H. Parker. A fine grandiceps with a large capitate head. $12 \times 3$ inches. [I raised a form of this in 1880 which Colonel Jones called capitatum lowei. The tips cristulate and crisp. $S \times 4$ inches ]

I 5. ramosum, Moore. Found in 1860 , in Hampshire, by Mr. C. Hillman. Branching at the base and also above. $12 \times 3$ inches (I 1 inches across the branches). [I raised a somewhat similar form some years ago, known as gleichenioides.]

\section{Section $\gamma$. SEMILACERUM.}

I. Aldreni, Lowe (omnilacerum Aldreni, Barnes: O. truncatum, IVollaston). Found in 1873 , near Milnthorp, by Mr. J. A. Aldren. Long acute lobes, and somewhit truncate apex. $21 \times 5 \frac{1}{2}$ inches.

2. brachiato-semilacerum, Jones. Found in I 862 , in Irorcestershire, by Mr. J. E. Mapplebcck. Hranching where the basal segments shoukl be. $17 \times 5 \frac{1}{2}$ inches; and 1 inches across the arms.

3. brachiatum, IVollaston. Found in 1856 , in Ciuernsey, by $1 / \mathrm{r}$. C. Jackson. $17 \times 5$ inches; and 8s inches across the arms.

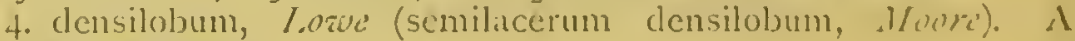
dense-lobed form.

5. srande, Lor'e (semilacerum gramele, fines). Found in IS $\$ 2$ in Wicklow. Near the rachis the pinnit are conthent and depatuperate. This matrnificent plant is in the possession of Mr. liarnard Hankey. $16 \times 13$ inclies. 
6. Hallii, Lorve (semilacerum Hallii, Jones). Found in VVentwood by the late Rev. C. Ranken Hall. Undulate. $12 \times 4$ inches. 7. illustre, Lowe. Raised by myself. Erect, stiff habit, foliose, distinct. I $8 \times 5$ inches.

8. Lowei, Lozve (semilacerum Lowei, Jones). Found by the late Colonel A. S. H. Lowe, near Athlone. A dense, imbricate form.

9. omnilacerum, Moore. Found in I 848, near Goodrich Castle, by Mr. T. E. Bennett. Segments ascending and confluent, the lobes having long, pointed projections. Distinct. $20 \times 5 \frac{1}{2}$ inches.

ro. Parsonsii, Lotue (brachiato semilacerum Parsons, Jones). Found in 1870 by Mr. Parsons. A brachiate semilacerum. Length, I 5 inclies.

II. robustum, Lowe (semilacerum robustum, Noore). Found in I863, at Whitbarrow, by Mr. J. M. Barnes. A grand foliose form. $19 \times 8$ inches.

I2. semilacerum, Link. Not uncommon in Nonmouthshire. Originally found in 1850 by the late Mrs. Delves, in County WVicklow. I $5 \times 7$ inches. [Mr. W. H. Phillips has found it in County Antrim. I $8 \times 9$ inches.]

I 3. truncatum, Lowe (semilacerum-truncatum, Bames). Found in IS63, in Levens Park, by $\mathrm{Mr}$. J. M. Barnes. The frond and also the divisions terminating in a horn.

I 4. unduatum, Lowe (semilacerum densilobum, Jones). A densely lobed form. I $8 \times 6 \frac{1}{2}$ inches.

\section{Section $\delta$. ANOMALUM. (Unclassified rarieties.)}

I. abruptum, Lowe (folioso-abruptum, Bames). Found in 1863 , in Witherslack, by Mr. J. M. Barnes. A fine, broad, leafy form.

2. acutum, Hoore. A characteristic form was found by the late Mr. Siclebotham in Patterdale. The lobes have no irregularities on the margins. Length, 6 inches.

3. auritum, Hoore. Found in numerous places. Eared.

4. Barnesii, Love (dentatum Barnesii, Moore). Found in I865, at Slackhead, by Mr. J. M. Bames. Deltoid, and evenly and deeply' dentate; not unlike Onoclea sensibilis.

5. crenatum, Moore. Not uncommon; with margins crenate. The late Colonel A. S. H. Lowe found a most marked form on Carberry Island, near Athlone.

6. Crossfieldii, Lowe (marginatum Crossfieldii, Moore). Found in IS62 at Arnside by Mr. J. Crossfield. A marginatum with pinniz as if bitten.

7. curtum, Wollaston. Found in I872, in Crake Valley, by Mr. J. K. Hodgson. A remarkable form, not unlike a clwarf Nephrolepis exaltata. Very narrow. $14 \times 1 \frac{3}{4}$ inches.

8. densilobum, Fitt. Narrow dentate segments. $8 \times 3^{\frac{1}{3}}$ inches.

9. dentatum, Hoore. Found in 1865 , in $1 V^{\top}$ estmoreland, by Mr. Barnes. $13 \times 7$ inches. Frond broad; lobes narrow and crowcled; margin dentate. Not uncommon. [A good form, found in Co. Clare by Mr. O'Kelly, has fronds $16 \times 5 \frac{1}{2}$ inches.] 
Io. depauperatum, Wollaston. Found in South Deron by Miss litson. A depauperate form, found on their garden wall at Shiphay. Cornute. $9 \times 4$ inches.

11. foliosum, Wollaston. Found in 1862, in Silverdale, by Mr. J. M. Barnes. Broad and leafy.

12. Huckii, Lowe (suprasoriferum Huckii, Barnes). A form having sori on the upper surface.

I3. irregulare, Moore. Found in 1864 , an Cartmel Fell, by Mr. J. M. Barnes. Frond and lobes irregular.

14. lineare, Lozve (marked "Irish Polypody" in Colonel Jones's collection). Very distinct, long linear lobes. $10 \times 0 \frac{3}{4}$ inches.

I 5. Llanvairense, Lowe. Found at Llanvair, near Shirenewton, by myself, in 1887. Segments narrow; apex of frond branching, and ending in 3 , or 4 , cornute tips. $10 \times 2 \frac{1}{2}$ inches.

16. macrostachya, O'K'elly. Found at Carron, Co. Clare, by Mr. P. B. O'Kelly. Normal, with a long caudate termination of the frond. $12 \times 3 \frac{1}{2}$ inches.

17. marginatum, Moore. Found in 1854, at Windermere, by Mr. F. Clowes. An interesting form, although it appears as if bitten. Mr. IV. H. Phillips has also found a good form. $16 \times 3$ incles.

IS. minimum, Hodgson. Found in 1866 at Millom by Mis. J. K. Hodgson. Fronds small and of many shapes.

19. Oakeleyæ. Lowe. Found by Mrs. Bagnall Oakeley at Penalt. Crenate; dark green. $16 \times 4$ inches.

20. obtuso-serratum, Moore. Found in 1863 , at Whitbarrow; by Mr. J. M Barnes. Cornute and serrate.

2r. rotundatum, Plitlips. Found in Ireland by Mr. IV. H. Phillips, and also by Mr. O'Kelly. Reduced to rounded lobes in basal portion.

22. serra, Wollaston. Found in 1865, in Lancashire, by Mr. J. Wilson. Very distinct; biserrate, and the lobes overlapping. $13 \times 23$ inches.

23. serratum, Moore. Found in several places. Cut like a saw.

24. sinuato-auritum, Moore. Found, in 1865 in Levens P'ark, by Mr. J. M. Barnes. Pinnae irregular.

25. suprasoriferum, Wollaston. Found in 1865 , on Cartmel Fell, by Mr. J. M. Barnes. Sori on the upper surface.

26. truncatum, Wollaston. Found in 1870 , in S. D)eron, by Miss kitson. Truncate. $13 \times 5$ inches. [Mr. P. B. O'Kelly has found a curious form in Co. Clare. $6 \times 2 \frac{1}{2}$ inches.]

27. variegatum, Barmes. Found in 1860, at Witherslack, by Mr. J. M. Barnes. A dwarf green-and-white variety.

28. Whitakeri, Loowe (dentatum Whitakeri, Moore). Found in I 864 , near kendal, by Mr. Whitalier. Evenly dentate. 


\title{
Tribe 12. GRAMMITIDEF.
}

THE SLENDER-LEAVED GYMNOGRAII.

GYMNOGRAMME LEPTOPHYLLA. $-D$ Desarax.

THE only British specics of the very handsome hot-house Gold and Silver Ferns. Diminutive. Length, 3 to 8 inches. Fronds fragile and few in number. Only found in Jersey, where it is abundant in several places. It is an annual; but if under suitable circumstances it will sow itself. Found on moist banks with a sunny aspect. A native of France, Switzerland, Germany, Spain, Portugal, Italy, Sicily, Sardinia, Dalmatia, Crete, and Greece ; India, Algiers, Morocco, Egypt, Abyssinia, and in the Atlantic Isles; Mexico and Australasia.

There are no varieties.

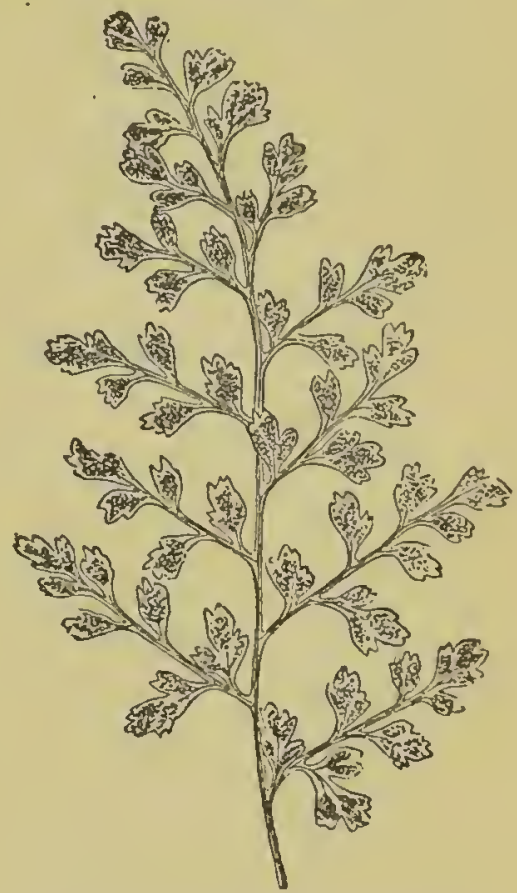

FIG. 4 6.-Frond of Gỵnogramme leptophylli.

\section{SUB-ORDER III. OSMUNDACEA.}

\author{
THE ROYAL FERN.
}

\section{OSAIUNDA REGALIS.-Linnaus.}

THE Royal, or, as it is often called, the Flowering Fern, is a most interesting and majestic species, and grows in situations where it can supply itself with water ; flourishing on the margins of lakes and rivers, and in swampy fields. It varies considerably in size (from I foot to as much as $\mathrm{r} 2$ feet). It is abundant at Shapwick, in Somerset, but very dwarf. In I 860 I noticed a number of plants in the crevices of low rocks at Santander, in $N$. Spain, by the side of the sea, where they must be frequently splashed by the waves. They were all small, none more than 6 inches ir length. In the early part of the present century, before the land was effectually drained it was not uncommon at Bulwell 
in Nottinghamshire. In 1855 only three plants could be found, and they were gradually perishing for want of water. One of these was removed into my fernery at Highfield House, and it is still alive; the other two perished in 1857 . It is, or was, found in twenty-six English, five Welsh, ten Scotch, and nine Irish counties, Anglesea, Isle of IVight, Arran, Bute, Mull, Islay, Uist, Harris, Lewis, Shetland, and Jersey. It is also widely spread on the Continent; in India, Algeria, Natal, Madagascar, Newfoundland, Canada, United States, Mexico, Brazil, and the Azores.

Fronds somewhat erect and trunk-like, the stipes being half the length of the frond; yellowish-green in colour, and broadly lanceolate in form ; the pinnules sometimes being $2 \frac{1}{2}$ inches long. The fronds are part sterile, and part have a terminal fertile panicle, giving the appearance of a flower. It cannot be mistaken for any other fern.

\section{VARIETIES.}

1. bulbifera, Lowe. The exact counterpart of cristata, but bearing bulbils at the base of the pinne. Raised from spores by $\mathrm{MI}$. Clift, of Birmingham.

2. capitata, Low'e. Dwarf. 16 inches in length, three-fourths of which is the stipes. Crown, spreading and almost creeping, making a wide plant with numerous fronds, which give a ball-like character. It is a conglomerate variety, and was raised from a bulbil of bulbifera by myself. The plant is still in my possession.

3. cristata, Moore. Extremely handsome. Length, 3 feet. The apices of all the pinnules are dilated and crested. It was introcluced by Messrs. Osborn \& Son, of Fulham. I had a plant in 1866 that was 14 feet in circumference.

4. interrupta, Moore. This has a few normal pinne, the remainder recluced in size, and of a rounder form.

5. Phillipsii, Lowe. Another interrupted form, found by Mr. IV. H. Phillips, of Belfast, in Co. Fermanah. It is more distinct than v. interupta. $36 \times 15$ inches.

6. purpurascens, Moore. Remarkable for its colour; but is distinct also in habit, not being unlike Osmundia spectabilis, a North American species.

7. ramo-cristata, Jones. Raised from spores. Almost a copy of cristata; but the stalk splits into two in the upper portion of lic frond.

S. undulata, Brown. From the Azores.

\section{SUB-ORDER VI. OPHIOGLOSSACELE.}

MOONWORT:

\section{JOTRICHIUM LUNARIA.-Sïcritz.}

A ComMon, but local, inconspicuous species; growing in dry mountain pastures; having a single, pimnate, stout, fleshy frond; 
varying from 2 to 10 inches, out of which rises the fertile spike, which sonew hat resembles a bunch of young grapes. Usually only one frond.

Found in most parts of Europe as far as the Arctic Circle, and within it, Also on the Himalaya and Rocky Mountains.

A botanical curiosity, difficult to cultivate.

Mr. Hoore has described three varieties: I. Rutaceum, found near Dundee ; 2 . tripartitum, in County Dublin; and 3. incisum, found at Halifax by Mr. Bolton; Crosby Ravensworth by Mr. Clarke; and near Dublin by Dr. Allchin. The latter has the pinnae deeply incised.

\section{THE ADDER'S TONGUE. \\ OPHIOGLOSSUM VULGATUM,-Limnceus.}

A Nother diminutive, inconspicuous fern, growing in moist, loamy pastures and woods; widely spread throughout Great Britain ; and throughout Europe. Also found in America, Mexico, New Zealand, New Holland, Cape of Good Hope, East Indies, Kamtschatka, and Siberia. Fronds, 3 to 12 inches in length; thin and fleshy. Frond entire and yellowish-green; the fertile spike rising from the base of the sterile frond. Creeping rhizoma, sending up solitary fronds; as it forms rhizomas, like the common Brakes.

\section{VARIETIES.}

I. lnsitanicum, Linnceus. Much more diminutive. Found in Guernsey, in 1854 , by Mr. G. Wolsey. [This may be a distinct species; as it has been found in about twenty other countries.]

2. microstichum, Moore. A very dwarf variety, with narrow fronds. Found at Swanbister, in Orkney, by Mr. J. T. Syme.

\section{CONCLUDING REMARKS.}

It only now remains to say a few words about how the varieties just described have been obtained. A certain portion are natural wild finds, whilst the remainder have been raised from spores. Every now and then a remarkably distinct variety has been found wild, but the occasions are few and far between; whilst, guidecl by judicious selection, the amount of forms that can be raisech from spores is practically inexhaustible. Wild finds are important, as new blood is infused into these crosses.

Whilst residing at Highfield House, near Nottingham, I began (in 1842) to cultivate British ferns. The only species then growing on that estate were a few examples of Asplenium adiantum-nigrum, on a new-red sandstone rock near the lake; one single example of the Asplenium Ceterach in a sunk-fence wall (erected in 1829); and some half-dozen plants of Aspidium aculeatum half a mile from the house ; the neighbourhood being singularly deficient of ferns. How- 
ever, after their cultivation for several years, the following could be found growing wild in suitable places: Scolopendrium vulgare, Asplenium Filix-fomina, Asplenium trichomanes, Nephrodium Filix-mas, Nephrodium paleaceum, Nephrodium spinulosum, and Aspidium angulare - not normal, but varictal forms, that owed their origin to the plants that had been introduced.

In 1867 I wrote "Our Native Ferns," and before that time began to raise varieties from spores.* In order to cconomize space, spores from the varieties of any one species were sown together; and from the plants so obtained it seemed certain that crosses had taken place whilst in the seed-pans. This circumstance caused a series of experiments, with a certain object in view, to be commenced. From these experiments it became evident that spores gatlered from a peculiar part of a frond would produce more striking results than from those gathercd haphazard. In is66 the late $\mathrm{Mr}$. Clapham had found Asplenium Filix-focmina, var. protemm, and in 1870 he sent me a plant. Spores of this were mixed with those of the rariety Victorice, and produced a series of forms having proteum as the one extreme and Victorice as the other; cvery seedling showing in a greater or less degree the peculiarities of the patrents. This series was seen in 1879 by $\mathrm{Mr}$. Clatpham, who before did not believe that ferns could be crossed, but who now became convinced; and on the strength of this conviction he mixed spores of Polypodium vulgare, var. Comubiensc, with the var. bifidocristctum, and raised a crested Cornubiense.

My next attempt was to cross species; and spores of Aspidium aculeatum were sown with those of Aspidium angulare. The object was, to obtain a narrow cruciate variety of Aspidium aculeatum, similar to the variety Wakelcyanum of Aspidium angulare, as this was as yet a desideratum. Spores of $W$ akeleyammm were sown with those of Aspidium aculeatum, var. dinsum: and out of a thousand seedlings there were five plants unmistakably Aspidium aculeatum, and having cruciate fronds like Wakeleyanum. In i $88+$ a short paper, with fronds of this cross, was sent to the Linnaan Society ; yet even this did not remove the doubt of Botanists; but a year later Sir Joseph Hooker informed me that the crossing of ferns was an acknowledged fact; and this change of opinion appears to have arisen from secing a foreign hybrid Adiantum. It is true, lowever, that in is68 the late Rer. M. J. liserkeley submitted a hybrid between Asplenium cbeneum and Scolnpendrium rhizophyllum to the late Sir IV. J. Hooker, who replied, it was" the most probable instance he had yet met with of a real hybrid amonerst ferns. In I 888 the late Colonel Jones and myself set forth. in a joint paper "On Abnormal Ferns" † at the liritish Asseriation mecting at Bath, our experience; Colonel Jones taking Aspidium,

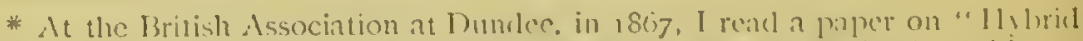

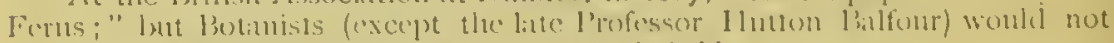
andent they were satisfied that ferms combl be lyylurids.

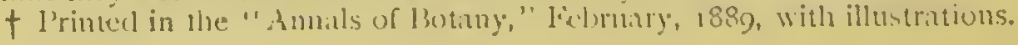


and myself the Hart's-tongue and Lady Fern. In the Lady Fern twelve marked varieties, and in the Hart's-tongue eight varieties, were sown together; and the result was, that seedlings were raised having the peculiar characters of three or four varieties blended in the samę frond. There are several hybrids now known besides the above: one with Asplenium trichomanes, another with Asplenium marinum, a third with Asplenium lanceolatum, the fern known as Nephrodium remotum, Pteris pendula, etc., and may I add Asplenium Germanicum. Although these are apparently fertile, plants have not been raised from their spores after frequent trials.*

Mr. James Britten, in his "European Ferns," mentions as foreign hybrids :-

Asplenium adulterinum, Milde (A. trichomanes + A. viride).

$"$ dolosum, Milde (A. trichomanes + A. adiantumnigrum).

ebenoides (A. ebeneum + Camtosorus rhizophyllus).

Scolopendrium hybridum (S. vulgare + A. Ceterach).

Adiantum Farleyense (A. capillus-Veneris + A. scutum?).

Nephrodium remotum (N. Filix-mas + N. spinulosum).

Space will not allow me to describe the reproductive organs; $\dagger$ it may however be mentioned that Professor Arthur Henfrey published in $185 \mathrm{I}$ a paper in which he stated that ten years previously Professor Nageli, of Zurich, had discovered the male organs, and in the year 1844 Count Leszazye-Suminski, of Berlin, had discovered both the male (Antheridia) and the female (Archegonia) organs, on the underside of the prothallus, $\ddagger$ during the prothalloid life of the fern; and on the male organs finding the female cell coition took place. Some experiments that I am now making, bearing on this subject, will, I believe, open up a new field of inquiry. In Mr. Druery's "Choice British Ferns," the reproductive organs are explained, as well as Mr. Druery's newly-discovered phenomenon of Apospory in Ferns.

It is an established fact, that the bulbils found on some varieties of ferns, do not always produce the same variety. Bulbils from the Scolopendriums "Wardii" and "Kelwayi" have yielded new" varieties; those from Aspidium angulare, Section plumoso-divisolobum, variety "densum," have originated the beautiful forms "Baldwini" and "imbricatum," and a bulbil from Osmunda regalis,

* Several plants have recently been raised from my liybrid Aspidium aculeatum, and also from Nephrodium remotum, but the nunber is insignificant.

+ Usually thc archegonia are situated in the kidney-shaped prothalli, just behind the indented 'portion, and the antheridia amongst the rootlets. The archegonia are bottle-shaped, with a rather long neck, and contain a minute central cell (oösphere). The antheridia are spiral ciliated bodies, endowed with movement and called spermatozoids. 'These pass down the neck of the archegonia and fertilizc the oösphere.-Britten's "European Ferns."

+ The prothallium was first noticed by Dr. Lindsay. - "Linn. Trans." 1792. 
variety "cristata," a grandiceps form. Even by apospory (i.e., prothalli formed directly on the frond, without the intermediate spore,) varieties are produced; and in the case of those from "Clarissima" (of the Lady fern) we may instance a subplumose form, a flexuose-pinnuled one, and another that is furcate and flexuose.

There is a peculiar connecting link between one species and another, for there is a mimical power that gives crested, branched, cruciate, and in short increased or diminished development in fronds, pinne, and pinnules, so that these characters are found almost identical in many species. Again, a well-developed variety may (as example) have a crested peculiarity in which the pinna copy the whole frond, and even the pinnules imitate the pinnx. Variegation can also be obtained by crossing. The late Colonel Jones exhibited a striking example in Aspidium angulare : having added the polydactylous character to a multilobe, he then succeeded in making it variegated by a second cross ; whilst in Scolopendrium vulgare I have obtained a dozen variegated forms.

The usual method of raising varieties is the one pointed out by me in 1867 ; but more recent experiments have shown that we can go beyond this. In I 888 experiments were made, based on the notion that it required a swarm of antheridia to malie the archegonia fertile. I had formed this opinion partly by what I had learned from Dr. Hudson on microscopic animal life, and partly on what I had done in crossing Dahlias. In the latter case, if I filled half a dozen small brushes with the pollen of a white Dahlia, and one with that from a coloured flower, and mixed these together (in the proportion of 6 to 1 ) and then impregnated a white flower, there was 87 per cent. of white seedlings, whilst if the process were reversed, i.e., six times as much pollen from coloured flowers, white was almost absent in the seedlings.* To get a certain desired colour, moist paints were mixed together in various proportions of white and colour; and this was imitated with so many brushes full of white pollen to one of the colour selected. This could not, however, be done with ferns; but certain proportions in bulk of spores from a crested Nephrodium paleaceum and of an uncrested variegated Nephrodium Filix-mas were sown together, and the plants (500 in number) though yet too small to exhibit variegation, are large enough to be crested, and every one of the plants is crested. If, therefore, it be desired to produce heavilycrested ferns, and at the same time to increase the size of the variety without reducing the crests; to make any alteration in form that shall not be at the expense of these crests, it is recominended that a much larger proportion of the spores of the crested than of the other form shall be sown together.

* As an experiment, in 1889 pollen was used from different genera and species; the seedlings have bloomed, and are like the seed-bearer. "The pollen was apparently able to give life to the seed, but not to slow any of the? characters of the male. 


\section{HINTS TO FERN CULTIVATORS.}

Ferneries. Mounds, unless with a considerable thickness of soil, are not suitable for ferns, as during droughts they become too dry; a sunken rockery (assuming the water can drain off) is far better. A north border (under a wall), some 5 or 6 feet wide (prepared with suitable soil), is one in which all large-growing ferns delight. On the other hand, an open windy position is the very worst that could be selected. Within a series of walls (like a ruined castle) is an admirable situation. Ferns planted near tree-roots often require the renewal of soil as it becomes exhausted.

Compost. This should be coarse, except the surface (in potculture), and the leaves used should only be half-decayed; roots grow much quicker and stronger when the soil is not too fine and close. Rock-ferns require the addition of stone, and do well (if in pots), plunged in a mixture of stone and compost in narrow boxes fixed against a north wall, a few feet from the ground.

Drainage. Perfect drainage is essential in pot cultivation, as ferns do not like water to stagnate about their roots. Cockle-shells, and above this a thin layer of spent hops, may be used with advantage, the roots receiving nourishment as well as drainage.

MLanure. Very weak manure water given occasionally; and old cow manure mixed in the compost is beneficial.

Watering and Syringing. Ferns require attention in watering, especially if young and delicate. Hunt's aphicide (a cheap spray distributor, made on a larger scale than the one in ordinary use), is an excellent instrument, holding a quart of liquid. A spray of water can be rapidly blown on the fronds. A solution of fir-tree oil blown through this "aphicide" on to the fronds lills insect pests, therefore another should be kept specially for this purpose. An excess of water is as injurious as a deficiency, and not constant small supplies, but a copious watering at proper intervals.

Shading. This is an important matter, especially with delicate plants. Ferns do not like full sunshine, and overhanging trees give too dense a shade. Exposed situations and green-liouses require shading. For years I have used the "Willesden Scrim"; it gives a subdued light without being too dense. I can recommend it as by far the best shading.

Gathering Fronds. Gathering fronds, and their breakage by wind or other causes, is a source of weakness to ferns. In drying fronds it is requisite to change the blotting paper frequently. "Bentham's Paper" is very good for the purpose; and a new blotting paper named liobosal seems, from a brief trial, to be equally good. The felt-like material used under carpets is a useful absorbent of moisture, if placed between newspapers containing fronds.

Slugs, Beetles, etc. Where houses are infested by beetles, Birkenleead's "beetle-trap" is effective. For eradicating slugs and woodlice, small heaps of a mixture of bran and vinegar will attract them ; and by visiting these heaps at night-time they may be cap- 
tured whilst feeding. A flower-pan with a canal surrounding it, made at the Royal Potteries, Weston-super-Mare, is a simple and useful contrivance; and "Toope's Plant Stand," i.e. a metal support surrounded by water, acts in a similar manner. Mr. P. Neill Fraser adopted this on a large scale for specimen plants twenty years ago.

Fern Hunting. When exploring the country for ferns, always have several tin boxes of about $20 \times$ I 4 inches, and about 3 inches deep; these will strap together so as not to be cumbersome. Carefully tie the fronds together, and place at once in the boxes, where they will remain for several days without injury; and the plants, when taken home, will not be unsightly for the rest of the summer. A record of each wild find should also be kept for future reference, giving date and locality.

Filmy Ferns. These require their fronds to be kept damp, without an over-abundance of water at the roots. A sunken pit ( 4 to 5 feet deep), covercd with glass and shaded with Scrim, is the most successful plan. In such a pit an extra cover in frosty weather is all that is required for the Killarncy Fern and Todea superba. Firc heat is injurious.

Raising from Spores. Freshly gathercd spores germinate more quickly than those from dried fronds. The time of their appcarance (as green specks) is variable; some will have put on their first frondlets in thrce months, whilst others may be more than a year before showing any sign of life. Conferve and mosses are apt to spring up and destroy the tiny forns whilst in their prothalloid growth. To prevent this, it is advisable to use a clean earthenware (glazed) pan, the soil having been previously plunged in boiling water to destroy the animal and regretable life contained in it. Protect with a glass cover, to prevent outside confervoid spores (of which the air is full) from being deposited on the soil, and use distilled water, or that which has been boiled, as ordinary water also teems with vegetable life. These pans, having no hole, do not require watering after the spores have been sown until the young ferns appear, i.e., if placed in a moderately damp situation and shaded. Worms also (that are destructive to infant ferns) do not get into the pans. Pricking out into small patches and ultimately dividing into single plants, is a delicate process, $r$ quiring great care and experience. In the earlier stages it is better to keep the soil damp by standing the small flower-pots in saucers of water, slightly wetting the frondlets with the spray distributor.

Attention to the above remarks may prevent disappointment.

Since "Our Native Ferns" was published, in 1S67, with the exception of the late Colonel Jones's privately printed "Varictics of the British Species," there has been no large work issued to illustrate the great number of marvellously beatiful ferns that have becn discovered or raised since that time. A new work is therefore much wanted; and the author of the present liandbook has been for some time collecting materials to supply this want, and would be glad to receive fronds of any new varieties. 


\title{
ADDITIONAL VARIETIES.
}

\author{
PTERIS AQUILINA.
}

17. tortuosum, Lozve. A large-growing variety in Mrs. Grant's fernery, with pinnules twisting in an extraordinary manner. Length, 4 feet.

\section{ADIANTUM CAPILLUS-VENERIS.}

33. cuneatoides, Lowe. A hybrid with adiuntum-cuneatum. Raised by myself. Forming a dwarf, dense bush.

34. minutopinnulum, Lowe. Raised by myself. Apparently a hybrid. Length 2 feet. Small, crowded pinnules.

\section{ASPLENIUM ADIANTUM-NIGRUM.}

16. plumum, Lorve. A grand feather-like hybrid (with asplenium marinum), with deep green fronds. In Mrs. Grant's collection. $3^{\frac{1}{2}} \times 4^{\frac{1}{2}}$ inches (of which $5^{\frac{1}{2}}$ inches is the stipes).

\section{ASPLENIUM FILIX-FCEMINA.}

A. I. B. GRANDICEPS.

3o. dentatum, Lowue. Raised by Mr. E. F. Fox. Profoundly dentate ; pinnze narrow and lax, and a much-branched capitate head 6 inches wide. $22 \times 4$ inches.

3r. superadornatum, Lowe. Raised by Mrs. Grant. Not unlike coronare, but with a larger and more dense head ( 5 inches wide). $23 \times 3$ inches.

\section{A. $x . \gamma$. CRISTATUM.}

45. cymba, Lowe. Raised by Mrs. Grant. A boat-like form as in cymbaforme, but the pinnæ are densely crested. $20 \times 3$ inches.

A. I. $\delta$. c.ruciatum.

6o. grandissimum, Lowe. Raised by Mrs. Grant. A narrow, lax, cruciate form of enormous length. Cruciate except a normal apex. Widest in centre of frond where $63 \times 4$ inches (at base only $I$ inch wide).

A. 2, $\alpha$. PUMULum.

22. cengere, Lone. Raised by Mr. E. F. Fox. Basal half lax, upper half congested. Sub-tripinnate. $27 \times 4$ inches.

23. prodigiosum, Lowe. Raised by Mrs. Grant. A narrow, confluent, feathery fern, with half the pinnæe all but wanting. $15 \times 2$ inches.

24. silvescere, Lozve (Fosteri, Jones). Found by Mr. Foster. A dense forest of d warf fronds forming a ball-like plant. $8 \times 2 \frac{1}{2}$ inches.

\section{A. 2. $\beta$. CRISPATUM.}

8. pavoninum, Lorve. Raised by myself in 1888 . A feathery capitate variety, with the pinnules roundly crested like the eye in the peacock's feather. $9 \times 2 \frac{2}{3}$ inches.

9. plumigerum, Lone. Raised by myself in 1888 . More feathery than pavoninzm and a stronger grower. $17 \times 4 \frac{1}{2}$ inches.

\section{B. 1. a. PLUMosum.}

22. Molyi, Lowe. Found by Mr. Moly. A finely cut plumose orm, widest in the middle of the frond, where $32 \times 12$ inches.

23. pluma, Lozve. Found by Mr. Moly. A narrow, lax, finely-cut plumosum, widest $n$ the middle, where $27 \times 7$ inches.

\section{B. $1 . \delta$. MACROPINNULUM.}

9. treda, Lowe. An unusually bold, polydactylous form raised by myself in 1888 . Pinnules of great size, capitate. $23 \times 9$ inches.

$$
\text { B. 2. a. LAXUM. }
$$

8. Illustre, Lonve. A distinct form, raised by myself. Pinne and pinnules very lax ; pinnules narrow and deeply cut; pinnee crested, and frond ramosely crested. $24 \times 7$ inches.

9. sponsa, Lozve. A large, distinct, very lax, feathery form, raised by Mrs. Grant. Some pinnx 2 inches apart, and very narrow ( $5 \times 0^{3}$ inches); pinnules cut to base, and lobes bidentate. $40 \times 9$ in centre of frond ( $\underset{165}{\operatorname{monly}} 3$ inches at base). 
I. variegatum, Moly. Found by Mir. Moly, in 1878 , at Colyton, Devon. Normal, but variegated.

The two following I do not know :-

* flabellifolium-tenue, Mapplebeck.

* Jonesii, Masplebeck.

\section{SCOLOPENDRIUM VULGARE.}

A. 1. B. CRISTATUM.

32. Jubatum, Lowe. Raised by myself. 'The crests falling over like a horse's mane. $16 \times 2$ inches. (Head 8 inches wide.)

A. I. 8. SAGITTATUM.

28. aureum, Lowe. A variegated sagittatum, raised by Mrs. Grant, $11 \times 2$ inches. B. I. $a$. CRISIUM.

58. caulitorquere, Lowe. Found by the late MIr. Wills. Rachis bending. $\{2 \times 2\}^{2}$ nches.

59. rugosocrispum, Lowe. Raised by myself. A cross between Cowburni and rugosum.

B. 5. $\alpha$. VARIGGATUH.

30. candicans, Love. Found at Hawkchurch, by Mr. Moly. Only narginally crisped. Pale golden variegation. $16 \times 2 ?$ inches.

\section{ASPIDIUM ACULEATUM.}

3o. conopeum, Lozve. A normal, lobate form, with a flat head so inches wide. Raised by the late Colonel Jones.

31. cruciferum, Lowe. Offspring of hybridum, raised by the late Mr. Barnes. Pinnules cruciate and narrow. $32 \times 6$ inches (in centre where widest).

32. distinctum, Lowe. Offspring of hybritum, raised by myself. Long, broad, cruciate, pinnules. Frond lax and broad at base, but mucli contracted in upper half. $27 \times 8$ inclies at base (and only $\mathrm{I}_{2}^{2}$ inclies in upper half).

33. filia, Lowe. Offspring of hybridum, raised by the late Mr. Barnes. Fronds foliose, concave, dark green, and very thomy. Pinna conlluent at the tips, cruciate; pinnules large and cruciate. $28 \times 4$ inches.

34. trapezipinnulnm, Lowe. Offspring of hybrilum and lonchitis. Kaised by ny. self. Fronds concave and deep green. Tips of pinnas confluent. Pimnules large, trapeziform, and strongly dentate. A distinct hybrid. $16 \times 4$ inches.

\section{ASPIDIUM ANGULARE.}

A. I. $\beta$. GRANDICE'S.

21. coronale, Lozve. Raised by Mr. E. F. Fox. Distinct, erect, with very dentate subrotund pinnules, and a much-branched, spirally-twisted, compact head. $20 x_{4}$ inches in middle (only I inch at base).

22. euprepes, Lorve. Raised by myself. Capitate.

23. surculosum, Lozec. A narrow, erect, capitate form, in Mirs. Grant's fernery, having conspicuous lobes. $30 \times 6$ inches in middle (only three inches at base).

A. I. $\delta$. POLYUACTYLUM.

14. excellens, Lowe. Raised by the late Colonel Jones. A narrow, polydactylons variet $y$, compaetly ivell branched. Pinnules simply lobed. $26 \times 6$ inches in middle (only 3 inches at base).

15. Foxii, Loave (remoto-decurrens polydactylum, Stansfield). A polydactyluus form, raised by Mr. E. F. Fox.

16. notabile, Lozve. Raised by the late Colonel Jones. A narrow, lax, crested form.

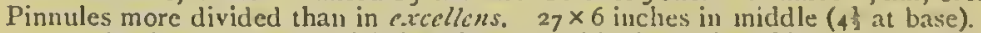

7. splendens, Lazve. Differing from notabile in having thick round crests. Raised by the late Colonel Jones. $24 \times 6$ inclies in centre (only 3 at base).

\section{A. I. ह. CRUC1ATUM.}

II. pretiosum, Lone. Raised by myself. Narrow, cruciate, dark green, with acute pinnules. $24 \times 2$ inches.

12. rectangulare, fones. Fonnd by Mrs. Wilson. I arge, lax, cruciatc, and capititte. Pinnules in lower half inerely lobate. $26 \times 6$ inches.

\section{A. 3. a. Fl, EXVOSUM.}

9. deforme, Loive. An ugly variety, found by Mr. Mloly. A tortuose lineare, with scarcely anything but the nidribs of pinnie and pimnules. Length of frond 25 inches, but only ro inches high.

ro. prosternare, Lovec. A very distinct, slender, pendulons, flexuose, depunperate and lax variety, raised from inurgalc-fureans, $2 x_{1}$ inclies, branching liead, 1 inclies.

11. torquere, Lowe. A very flexuose form. Found by Mr. Aloly. $26 \times 4$ inclies.

12. tortum, Lonce. A narrow twisted variety. Fumd by Mr. Moly, $30 \times 3$ inches. 
B. I. a. Plumosum.

12. penna, Lowe. A plumose form raised by myself in 1887 . Tips of pinnæ curling over and polydactylous. $24 \times 7$ inches.

B. т. $\delta$. MACROPINNULUM.

9. lucidum, Padley. Large pinnules, and shining, pale-green fronds.

\section{B. 3 . $a$. DECompositum.}

18. pluma, Lozve. A very plumose form of Mr. Padley's tripinnatum. Raised by the late Colonel Jones. $24 \times 8$ inches.

19. pteron, Lonve. A narrow plumose form of Mr. Padlcy's tripinnatum. Raised by the late Colonel Joncs. $26 \times 4 \frac{1}{2}$ inches.

20. vcnustum, Lonve. Raiscd by myself. A tripinnate divisolobe, narrowing to the apex. $40 \times 10$ inches (at base).

\section{B. 3. $\beta$. ACUTILOBUM.}

26. Germinere, Lorve. Raised by the late Colonel Jones. A distinct narrow acutilobum. Frond equal in width. Pinnae so much branched as to be broader than long. $14 \times 3 \frac{1}{3}$ inches.

27. invincere, Lozve. Raised by Mr. E. F. Fox. A grandly polydactylous acutilobum. $23 \times 9$ inches (at base).

28. Trevellyanz, Lowe. Found in Somerset, by the late Mr. Elworthy. Piunx overlapping : pinnules long, narrow, and lax. $30 \times 9^{\frac{1}{2}}$ inches.

29. viviparum, Lozve. An acutilobuen with plants along the rachis. In Mrs. Grant's fernery. $16 \times_{5}$ inches (at base).

P. 4. a. ROTUNDATUM.

16. circulare, Lorve. Raised by the late Colonel Jones. Distinct, subrotund form with lax pinnules. $25 \times 3^{3}$ inches (in middle), only $2 \frac{1}{2}$ inches at base.

7. exile, Lowve. Found by Mrs. Grant. A gracile-looking, conspicuously lobed variety, with lax pinnules. $27 \times 9$ inches (in middle), only 4 inches at base.

\section{B. 4. $\gamma$. LACINIATUM.}

26. bellulum, Lone. Found by Mr. Moly, in Dorset. Not unlike a narrow remotodecurrens. $23 \times 4$ inches.

27. caudatum, Lowe. Raised by myself in 1887 . A distinct caudate grandidens. $16 \times 4$ inches at base, and only 1 inch near the tip.

\section{2. $a$, ANGUSTATUM.}

5. arctum, Lowe. Found at Uplyme, by Mr. Moly. A pretty, narrow, dark-green form, with blunt-ended, imbricate pinnules. A bird's-nest-like habit.

\section{I. $\alpha$. VARIEGATUM.}

16. antumnale, Lowee. Raised by Mr. Fitt. Not unlike Mr. Parson's foliosum, but green and gold. $20 \times 6$ inches.

\section{NEPHRODIUM FILIX MAS.}

*53. Festingii, Thompson. From the South Kensington collection,

54. revolvere, Lozve. Found by Mrs. Grant. A revolved Stableri. $29 \times 5$ inches.

\section{NEPHRODIUM PALEACEUM.}

41. grandescere, Lonve. A very refined yet giant form, having embossed pinnules Found by Mr. Moly. $52 \times 10$ inches in ccntre : only $2 \frac{1}{2}$ inches at base.

42. ornamentum, Lowe. A neat variety with dense pinnz. Found by Mr. Moly $44 \times 7$ inches.

\section{NEPHRODIUM SPINULOSUM. (Subsection dilatatum.)}

18. diversopinnulum, Lozve. Found by Mr. Moly. A distinct, pretty, very lax, depauperate form. $32 \times 1_{4}$ iuches (stipcs 15 inches).

\section{POLYPODIUM VULGARE. (Subsection semilacerum.)}

15. Tinternense, Lonve. A plumose form, obtained in 1847 , on the ruins of Tintern Abbey, by Coloncl Randall, and independently, some 30 years ago, by Mr. Cowburn. It is not now however to be found there. A large, graccful variety, much divided in the centre of the pinnæe in a regular manner. $23 \times 6$ inchcs.

The above additions increase the list as follows :-

Pteris Aquilina . . . . . 17

Adiantum Capillus Veneris : $\quad 34$

$\begin{array}{lr}\text { Asplenium adiantum nigrum . } & \text { I } 6 \\ & \text { filix formina }\end{array}$

" filix foemina . . $3 \times 3$

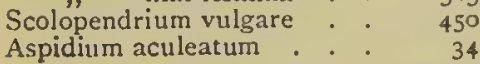

VARIETIES.

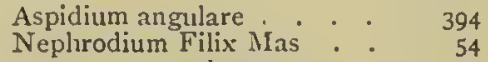

42

47

Polypödium vulgare . . . 75

The number of varieties described in this Handbook is 1859 . 


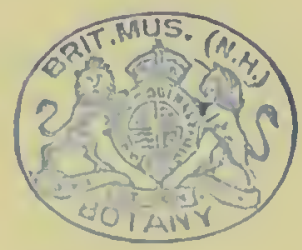




\section{SPINK \& SON,}

THE OLDEST-ESTABLISHED

\section{国ealers in Coins 证起ledals,}

17 \& 18, PICCADILLY, W., LONDON,

Beg respectfully to announce that they

HAVE FOR SALE

The following Sipecialities at low prices:-

ENGLISH GOLD, SILVER, AND COPPER COINS. FINE PROOFS, PATTERNS, Etc.

FOREIGN GOLD, SILVER, AND COPPER COINS. TOKENS OF EVERY VARIETY in SILVER \& COPPER. WAR MEDALS AND DECORATIONS.

COMMEMORATIVE MEDALS.

MEDALS IN SILVER \& BRONZE of Celebrated Men. MEDALS OF PUBLIC BUILDINGS, Etc.

EARLY BRITISH COINS, in Gold, Silver, and Copper. ROMAN Ditto.

GREEK

INDIAN

EARLY COLONIAL ,

EARLY AMERICAN ,

COIN CABINETS.

MEDAL CABINETS.

NUIMISMATIC WORKS BY THE BEST AUTHORS. MINIATURE MEDALS FOR ALL CAMPAIGNS. BYZANTINE COINS.

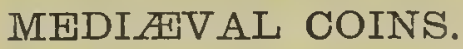
SAXON PENNIES.

IES ALL COINS AND MEDALS GUARANTEED GENUINE. 


\section{To Gollectors of Coins and Medals.}

\section{.

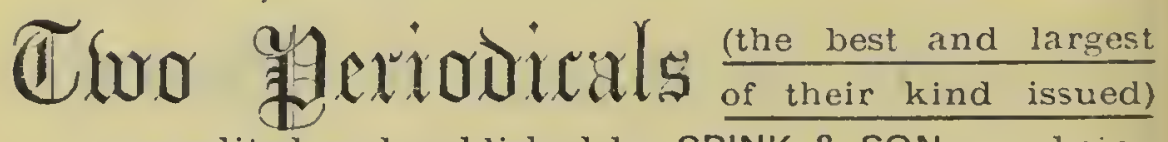 are edited and published by SPINK \& SON, one being expressly devoted to the interests of Collectors of Coins, whilst the other refers entirely to War Medals and Decorations (the only Magazine solely devoter to this interesting pursuit).}

\section{(1) "MONTHLY NUMISMATIC CIRCULAR"}

Is a High-class Illustrated l'eriodical, containing Original Articles by Talented Numismatists, both English and Continental, of the deepest interest and utility for all classes of Collectors of Coins, and to those in any legree acquainted with the Science. Each montl there is also included a speciallyprepared Catalogue of beautiful Coins for Sale at very moderate prices.

SPECIMEN NUMBER GRATIS.

ANNUAL SUBSCRIPTION (including Postage), $2,0$.

\section{(2) "THE WAR MEDAL RECORD,"}

INCLUDING;

ORDERS OF KNIGHTHOOD \& HONORARY DISTINCTIONS.

Devoted solely to the study of War Medals, Sc., from the IIistorical and Collector's point of view. $\Lambda$ most valuable journal, containing Original Notes contributed by CAPT. TANCren (the learned author of The Historial lieined of Medals). Also numerous Illustrations of unique and rare Medals and Decorations. PUBLISHED QUARTERLY.

SPECIMEN NUMBER GRATIS.

ANNUAL SUBSCRIPTION (including Postage), 126.

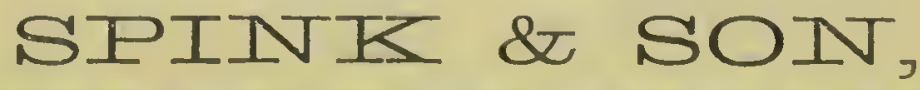

EXPERTS IN COINS AND MEDALS 17 \& 18, PICCADILLY, LONDON, W. 
44 Prize Medals, Diplomas, and

Royal Appointments Awarded.

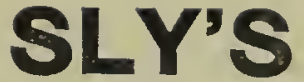

IMPIOV耳D
44 Prize Medals Diplomas, and

Rojal Appointments Awarded.

\section{PATENT TRUSS}

\section{SUPERSEDES ALL OTHERS.}

Worn by Sir A. CLARK, late President of the Royal College of Physicians. Recommended by Sir BENJAMIN WARD RICHARDSON.

44 Prize Medals, Diplomas, \& Royal Appointments Awarded. WRITE FOR PARTICILAKS AND PRICES-

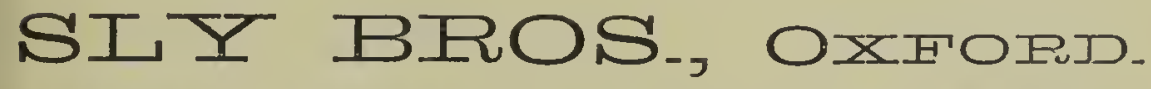

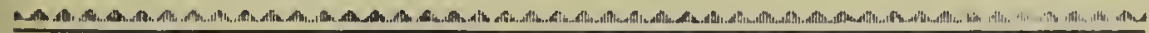

YOUNG COLLECTOR SERIES.

Fully Illustrated. Crown 8vo, Cloth. Each ONE SHILLING.

ANTS, BEES, WASPS, AND DRAGON FLIES - W. H. BATH. BIRDS (British)

Rev. H. A. Macpherson. BOOK COLLECTING J. H. Slater. BUTTERFLIES, MOTHS, AND BEETLES。 W. F. KIRBY, F.L.S., F.E.S. CHESS PROBLEMS

E. W. RAYNER. COPPER COINS OF EUROPE

F. C. HIGGINS. COLONIAL COINS

FERNS (British)

FOSSILS (British)

GRASSES MOSSES

REPTILES

SILKWORMS COINS AND TOKENS (English).

CRUSTACEANS AND SPIDERS .

FUNGI, LICHENS, Etc.

LAND AND FRESH-WंATER SHELLS

POND-LIFE (Insects).

POND-LIFE (Algæ, Diatoms, etc).

POSTAGE STAMPS

SEAWEEDS, SHELLS, AND FOSSILS

THE TELESCOPE
WILD FLOWERS (Spring), REV. H. WOOD ; (Sumer) do., REV. H. WOOD.

LiEw. JEWITT, F.S.A.

D. F. HOWORTH, F.S.A.

F. A. SKUSE.

E. J. Lowe, F.R.S., F.L.S.

J. W. Williams. Peter Gray, A.B.S. IV. Hutchinson.

- J. W. WILliaMs.

J. E. Bagnall, A.L.S.

E. A. Butler, F.Z.S. T. S. SMITHSON. W. T. Ogilvie. C. Hopley.

P. Gray \& B. B. Woodward. E. A. ButLER, F.Z.S. J. W. WILliaMs. SWAN SONNENSCHEIN \& CO., LONDON. 


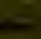

InOOWE

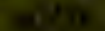

Funis: (1898).

Firs Premuber $£ 721000$

Whe Freasione

820203

Inse

का ड, 6 .

A

Funve

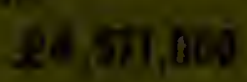

ran

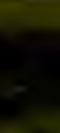

$=$

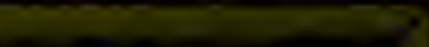

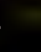

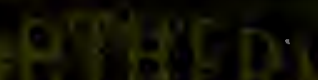

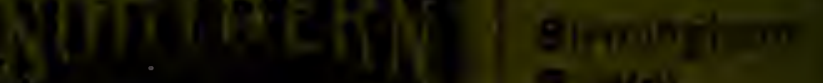

3

.

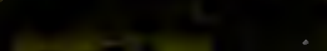

aivito\},

Dubiln.

Dumitas.

Edintsuth

Glis sow:

Lิำเ an

Muthetes sy

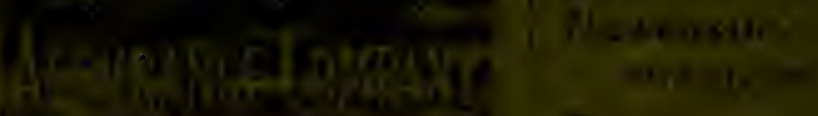

$-9$

$x=\vec{r}$

Fin 5 , 1,0 .

Mun

Melbens:

\section{Hegd Ollees:}

COKOOW :

BSTOEEY:

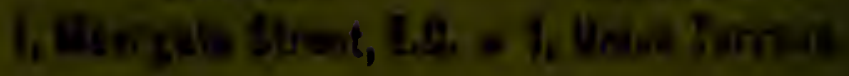

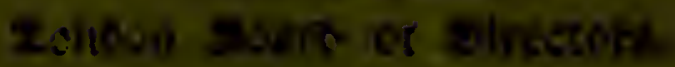

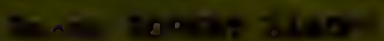

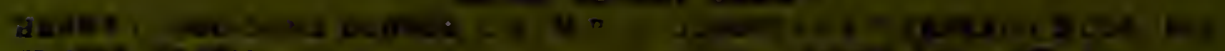

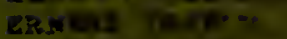

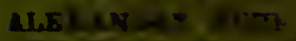

REF

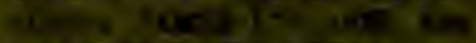
in

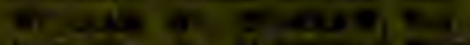

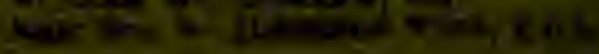

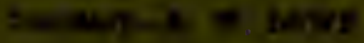

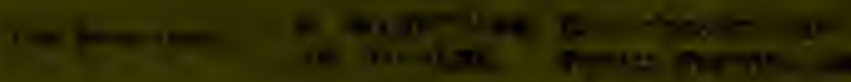

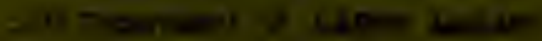

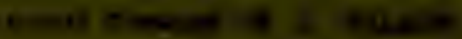


preserifed.

$$
\text { El63 2.7.1973 }
$$




fot

if

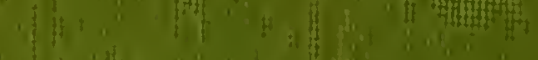

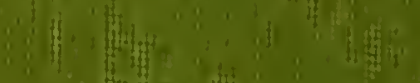

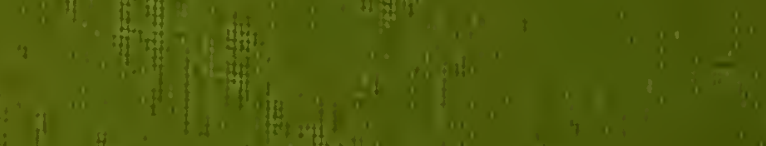

$\therefore$ i

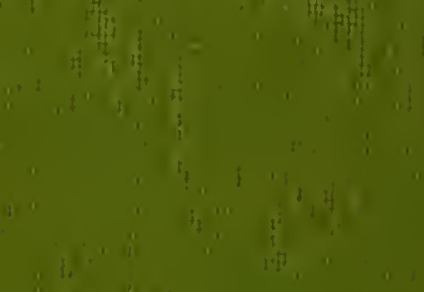

- ith

$4^{4} \div$

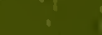

10

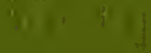

$$
\frac{2}{7} \quad \text { is : }
$$

1
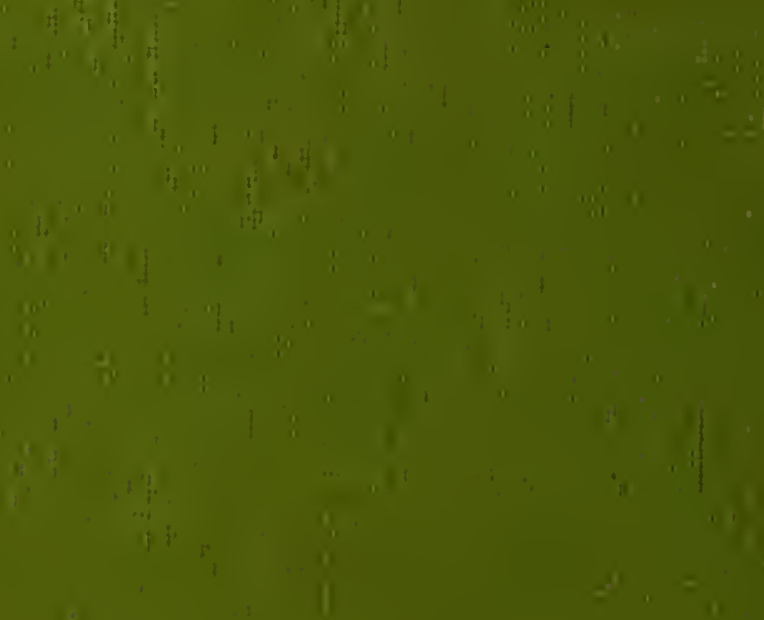

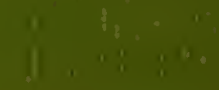

1

|
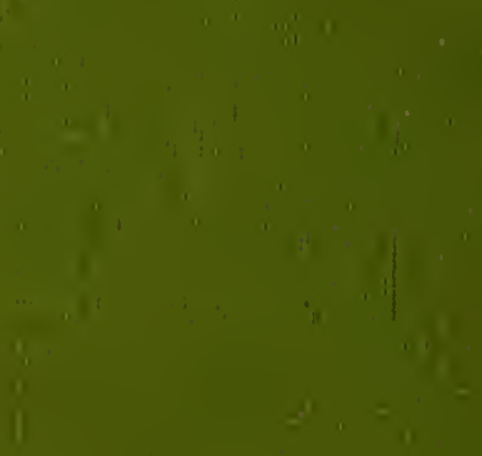

$+\cdots, \cdots$

1
1
11
11
1
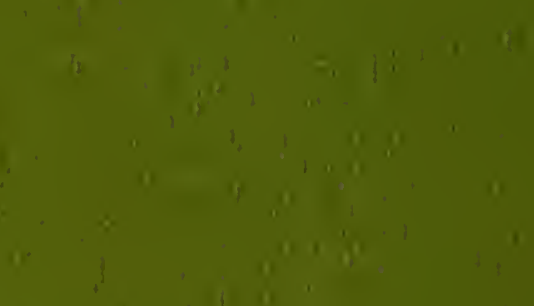

\begin{abstract}
81
\end{abstract}
,

,

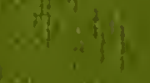

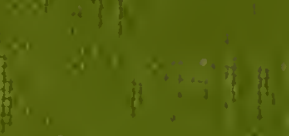

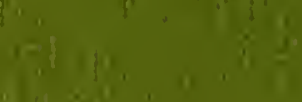

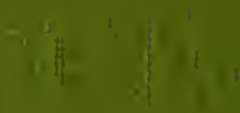

11.

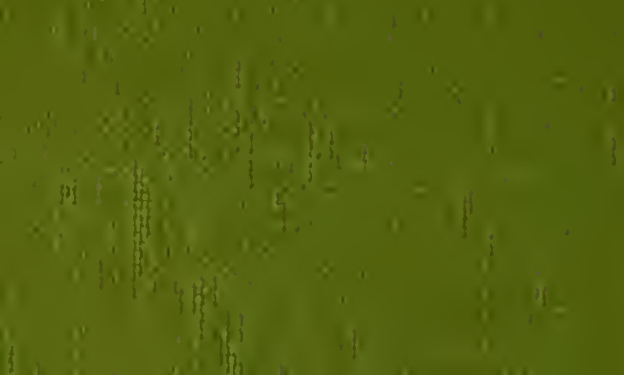

